el formacias das representacioses sobre a cidade colonial yo Brasil

GEORGE ALEXANDRE FERREIRA DANTAS

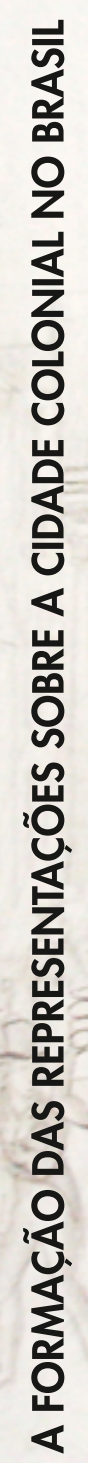

EESC - USP
2009 
A FORMAÇÃO DAS REPRESENTAÇÕES SOBRE A CIDADE COLONIAL NO BRASIL

George Alexandre Ferreira Dantas 



\section{A formação das representações sobre a cidade colonial no Brasil}

Tese apresentada ao Programa de Pós-Graduação em Arquitetura e Urbanismo da Escola de Engenharia de São Carlos - Universidade de São Paulo como requisito parcial para obtenção do título de Doutor

Doutorando

George Alexandre Ferreira Dantas

Orientador

Prof. Dr. Carlos Roberto Monteiro de Andrade

Financiamento

Fundação de Amparo à Pesquisa do Estado de São Paulo [05/51462-8] 
Capa: Ítalo Dantas de Araújo Maia

Imagem da capa: J. M. Rugendas, Rua Direita no Rio de Janeiro

Fonte: BELLUZZO, Ana Maria de M. O Brasil dos viajantes. 2 ed. São Paulo: Metalivros: Rio de Janeiro: Objetiva, 1999, vol. III, p.79.

AUTORIZO A REPRODUÇÃO E DIVULGAÇÃO TOTAL OU PARCIAL DESTE TRABALHO, POR QUALQUER MEIO CONVENCIONAL OU ELETRÓNICO, PARA FINS DE ESTUDO E PESQUISA, DESDE QUE CITADA A FONTE.

Ficha catalográfica preparada pela Seção de Tratamento

da Informação do Serviço de Biblioteca - EESC/USP

\begin{tabular}{|c|c|}
\hline D192f & $\begin{array}{l}\text { Dantas, George Alexandre Ferreira } \\
\text { A formaçăo das representaçסes sobre a cidade } \\
\text { colonial no Brasil / George Alexandre Ferreira Dantas ; } \\
\text { orientador Carlos Roberto Monteiro de Andrade. -- Säo } \\
\text { Carlos, } 2009 \text {. }\end{array}$ \\
\hline & $\begin{array}{l}\text { Tege (Doutorado-Programa de P6a-Graduação em } \\
\text { Arquitetura e Urbaniamo e Ârea de Concentração em Teoria } \\
\text { e Hiat6ria da Arquitetura e do Urbaniamo) - Eacola de } \\
\text { Engenharia de säo Carlos da Universidade de são Paulo, } \\
\text { 2009. }\end{array}$ \\
\hline & $\begin{array}{l}\text { 1. Cidades coloniais. } 2 \text {. Representaçōes. } \\
\text { 3. Historiografia. 4. Arquitetura. 5. Urbanismo. } \\
\text { I. Titulo. }\end{array}$ \\
\hline
\end{tabular}


FOLHA DE JULGAMENTO

Candidato: Arquitcto c Urbanista GEORGE ALEXANDRF. FFRRFIRA DANTAS.

Tese defendida e julgada em 05/08/2009 perante a Comissăo Julgadora:

Carles de Alrade aprovade

Prol. Dr. CARLOS ROBERTO MONTEIRO DE ANDRADE (Orientador)

(Escola de Engenharia de Sāo Carlos/USP)

Prof". Associada CIBELE SALIBA RIZEK

(Escola de Engenharia de Sāo CarlosiUSP)

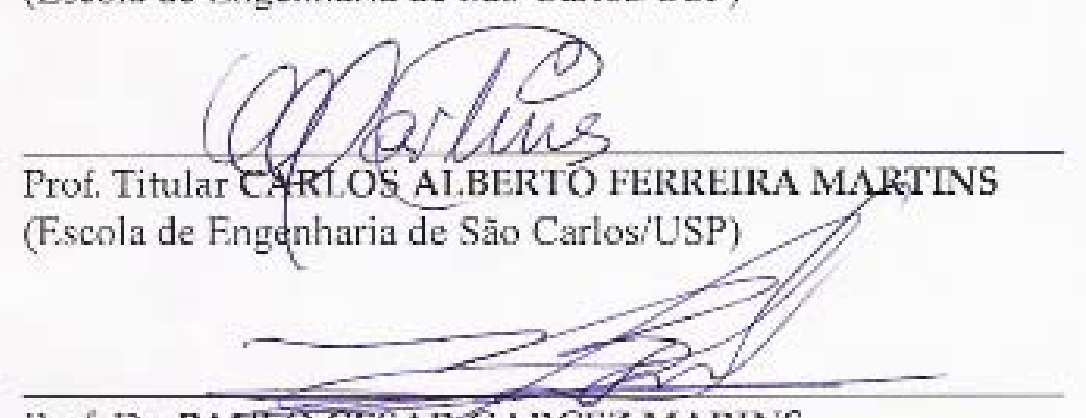

aprovedo

Prof. Dr. PAULO CESAR GARCEZ MARINS

(Museu Paulista (JSP)

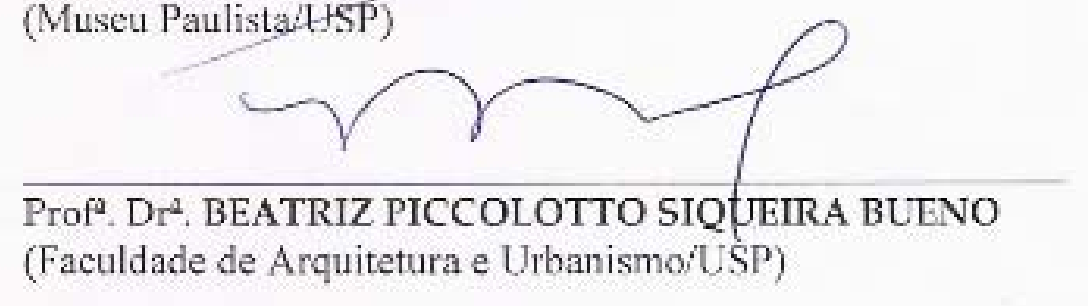

aprorado

Prof ${ }^{2}$. Dr ${ }^{2}$. BEATRIZ PICCOLOTTO SIQUEIRA BUENO

aprovodo
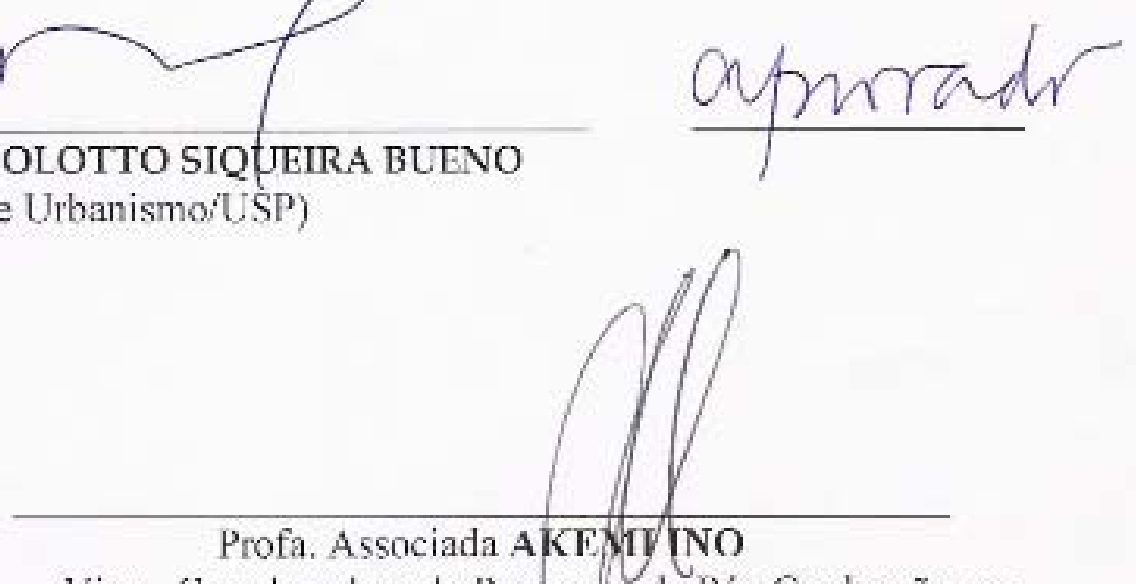

Vice - Coordenadora do Programa de Pós-Graduação em Arquitetura e Urbayismo

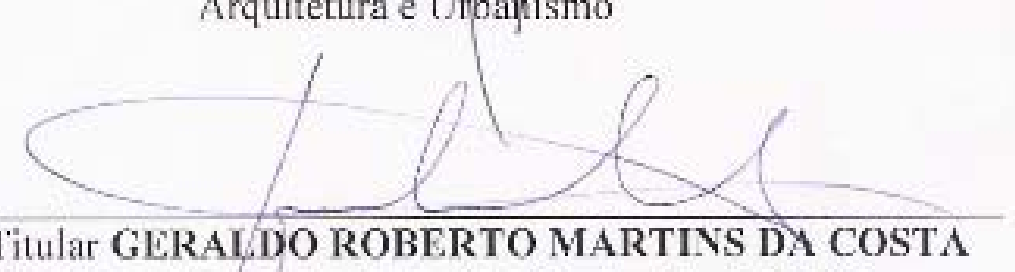

Prof. Titular GERALDO ROBERTO MARTINS DA COSTA Presidente da Comissão da Pós-Graduação da FESC 

Para Ana Karina e Ana Helena. 

"Todo lenguaje es un alfabeto de símbolos cuyo ejercicio presupone um pasado que los interlocutores comparten"

Jorge Luis Borges, “El Aleph”, El Aleph 



\section{AGRADECIMENTOS}

Sou um leitor de páginas de agradecimentos. Repetitivas, por vezes, inusitadas outras tantas, mesmo assim sempre ajudam a contar a história pessoal e de pesquisa de uma tese, as interlocuções e os alicerces - teóricos, metodológicos e, antes de mais nada, afetivos - que a sustentam. Não posso deixar de fazer o mesmo e espero que essas páginas possam assim ser lidas.

Os anos para o desenvolvimento de uma tese de doutorado são intensos, longos. É uma tessitura sem fim, peça que recebeu mãos amigas no desenrolar inicial, na construção da estrutura, na distribuição dos fios e nos arremates, moldando pequenas mas significativas iluminuras no resultado final, cujo desenho, ainda incompleto, foi rabiscado em vários momentos - também literalmente, em uma folha sulfite avulsa não mais tão branca que acompanha meu caderno de notas de pesquisa -, acrescentando linhas, palavras-chaves e muitas interrogações. Assim, dessas mãos me ocupo agora.

Antes de mais nada, lembro que voltar a São Carlos foi enriquecedor, pessoal, profissional e academicamente. E é dessa satisfação pessoal - de estar por mais de sete anos, somando o período de mestrado, em uma cidade que aprecio - que inicio meus agradecimentos:

Uma vez mais, ao Prof. Carlos Roberto Monteiro de Andrade, pelo compromisso intelectual de ajudar a levantar os alicerces desta tese, pelos contatos e conversas inúmeras, mesmo à distância, desde o início do mestrado em 1999 e na volta para o doutorado em 2005, pelo incentivo, confiança e pela amizade que vão além da orientação;

Aos professores do Programa de Pós-Graduação em Arquitetura e Urbanismo da EESC-USP, cujas reflexões, dentro e fora das disciplinas curriculares, foram importantes para meus próprios questionamentos. Dentre todos, não posso deixar de citar nominalmente Carlos Martins, Renato Anelli, Telma Correia, Cibele Saliba Rizek e Sarah Feldman; 
Aos funcionários do Departamento de Arquitetura, pelo apoio para desfazer nós burocráticos e pelas amenidades da hora do café: João Tessarin, Paulo Ceneviva, Benê, Geraldo, Osvaldo, Zanardi e, em especial, Fátima e Marcelo Celestini, por meio de quem agradeço aos outros não nomeados;

Aos funcionários das diversas bibliotecas da USP onde pesquisei ao longo dos últimos quatro anos (da Faculdade de Direito do Largo São Francisco, da Central da Politécnica, da Faculdade de Filosofia, Letras e Ciências Humanas, da Faculdade de Arquitetura e Urbanismo na Cidade Universitária e na Rua Maranhão, e, em especial, do Instituto de Estudos Brasileiros e da Central da EESC); importante também o trabalho da equipe do Lig Doc, sobretudo à Adriana Perez Gomes, operadora constante dos meus inúmeros pedidos de artigos e capítulos;

Do mesmo modo, aos funcionários das diversas bibliotecas e arquivos de outras cidades por onde pude passar e trabalhar: em Natal, na Biblioteca Central Zila Mamede, da UFRN; em Recife, na Fundação Joaquim Nabuco; no Rio de Janeiro, na Biblioteca Nacional e na Biblioteca Paulo Santos; em Campinas, na Biblioteca Central da Unicamp (em especial, na seção de obras raras), do IFCH e no Arquivo Edgard Leuenroth, a quem agradeço em especial ao Mário e à Isabel, que sempre facilitaram e agilizaram a pesquisa nas micro-fichas; em Buenos Aires, na Biblioteca Nacional, no acervo da Sociedad Central de Arquitectos e na Academia Nacional de Historia; em São Carlos, na Biblioteca Comunitária da UFSCar, em especial aos que mantêm a sala de coleções especiais;

Em meio às viagens de pesquisa, recebi a ajuda de várias pessoas. Em Buenos Aires, o prof. Luis Maria Calvo (da Universidad de Buenos Aires) deu-me indicações importantes para o trabalho nos arquivos; Maria Martina Acosta também apontou arquivos e ajudou-me com informações diversas sobre Buenos Aires; o prof. Adrián Gorelik (Universidad de Quilmes) discutiu meu projeto e apontou várias possibilidades de história comparada (que teremos que guardar para depois). Em Quito, o prof. Eduardo Kingman (Flacso-Ecuador) foi muito gentil ao nos receber na sessão de história urbana do Congreso Latinoamericano de Ciéncias Sociales e nas andanças pela cidade;

Às professoras Beatriz Piccolotto Siqueira Bueno (FAUUSP) e Cibele Saliba Rizek (EESC-USP) pela leitura cuidadosa, pelas indagações inspiradoras e pelas 
inúmeras contribuições para pensar esta tese, seus argumentos e estrutura; na banca final, tive a satisfação de contar também com as argüições precisas dos professores Paulo Cesar Garcez Marins (Museu Paulista-USP) e Carlos Alberto Ferreira Martins (EESC-USP).

Ao professor Nestor Goulart Reis (FAUUSP), pela entrevista/conversa que ajudou a esclarecer várias questões na reta final da escrita e me levou a repensar algumas partes e conclusões;

Aos professores José Xaides e Antonio Carlos, do Departamento de Arquitetura, Urbanismo e Paisagismo da UNESP, campus de Bauru-SP, pela confiança e oportunidade oferecidas durante o ano e meio que trabalhei como professor na disciplina de "Linguagem e valor estético"; aos alunos que aceitaram partilhar (e, assim, se enlevar em) a trama fugidia que é a discussão sobre arte, cultura, arquitetura e história; lá contei também com a gentileza do Leopoldo e da Mitsue na secretaria do curso;

Aos amigos que são também parceiros intelectuais leais e críticos, por vezes severa e necessariamente críticos, mas, antes de tudo, afetuosos: Hamilton Varela, Paula e família, que sempre nos deram muito apoio; Giuseppe Câmara e Janete Giz; Francisco Sales e Ingrid; Rodrigo Firmino e Alessandra; Michelly Ramos e Vitor de Ângelo. Dentre esses, não posso esquecer do Fernando Atique, cujo apoio material e fraterno foi imprescindível tantas vezes, em São Carlos e, depois, em Campinas; na reta final, o incentivo da Renata Cabral foi decisivo;

Não posso esquecer também que foi com Rodrigo, Sales e Michelly que partilhamos a construção do projeto do Café com Pesquisa, série de seminários (realizados entre 2005 e 2008) que nos ajudou a conversar mais entre nós mesmos e com nossos colegas, afastando-nos, ainda que por alguns momentos, do encastelamento por vezes inevitável da pesquisa e da reflexão; aí nossas amizades e respeito se fortaleceram;

Aos amigos e colegas que partilharam os anos iniciais, em meio à disciplinas, elaboração de monografias, conversas, cafés, angústias, risadas, enfim ao cotidiano acadêmico da pós-graduação: Amanda Ruggiero, Caliane Almeida, Carolina Rossetti, Cecília Almeida, Débora Foresti, Fúlvio Teixeira, Juliano Cecílio, Luiz "Peixe" Teixeira, Marcus Vinícius Queiroz, Paula Francisca, Sara Grubert, Teresa Cordido; 
depois, também, Adriana Almeida, Carolina Chaves, Mayara Mendonça, Marcos Santos e Olívia Maia; não posso deixar de lembrar também de Claudius Barbosa, Cristina Campos, Fabiano Oliveira e Pedro Rossetto;

Aos inestimáveis colegas e amigos do Urbis, que sempre acreditaram e torceram muito por mim: Cecília Lucchese, Fabíola Cordovil, Lucas Cestaro, Luisa Videsot, Maristela Janjulio, Thais Cruz e, depois, Ana Carolina Froes e Lorenza Pavesi;

Tenho uma dívida grande para com o HCUrb (grupo de estudo em História da Cidade e do Urbanismo, vinculado à Base de Pesquisa "Estudos do Habitat", do Depto. de Arquitetura da UFRN), pelo incentivo constante às minhas pesquisas, pelo aprendizado que o trabalho e a reflexão coletivos são possíveis e importantes e, enfim, pela amizade: a Angela Ferreira, Ana Caroline Dias, Anna Rachel Eduardo, Alexsandro Ferreira, Gabriel Medeiros, Hélio Farias, Yuri Simonini, além de Adriano Wagner, Luiza Lima, Clara Rodrigues, Fabiano Fechine, Giovana Oliveira e Paulo Nobre; no final, Yuri, Gabriel e Rachel deram-me um grande ajuda na revisão dos capítulos e Hélio pôs nos eixos o que eu tinha alinhavado como abstract,

Aos amigos de Natal, João Pessoa e alhures: Alex e Janaína, André e Alândia, Marco Coutinho, Marcos Dantas Jr., Nilton Santos, Philippe Guaigner e Rosa, Rossana Honorato, Sheila Paiva, Vinícius Dantas, Wagner Martins e tantos outros;

A Fapesp (processo 05/51462-8), cujo apoio material e conceitual (por meio das contribuições e críticas do/a parecerista) foi de fundamental importância para o desenvolvimento desta tese;

Por fim, à minha família, sempre presente e divertida, ainda que à distância: aos meus pais, Edmundo Eugênio e Expedita Ferreira, e a meus irmãos, cunhadas e sobrinhos, Leonardo, Suênia, Murilo e Diogo, Gustavo, Aline, Anastácia e Alicia (recém-nascida), Cláudio e Jamile. Em Campinas, contei sempre com o apoio e o entusiasmo de Hélio Ferreira e Idati Sigo, Alexander e Raquel, Alessandro, Ana Paula e Vinícius. Aos meus sogros, Marcos e Albanita; a Marcos Jr. e Érika. Há outros que gostaria de aqui nomear, mas a tarefa seria longa, ainda assim registro que são também especiais para mim. Por fim e em especial, para Ana Karina e Ana Helena, que construíram comigo esta tese. Helena nasceu em meio a toda essa história (em 
julho de 2006) e fez-me reescrever minhas escolhas, planos, itinerários, para fazê-las nossas, para fazer tudo valer a pena, nossa iluminura.

São Carlos, junho (ainda outono) e agosto de 2009. 



\section{RESUMO}

\section{A formação das representações sobre a cidade colonial no Brasil.}

A crítica da cidade colonial foi um dos principais temas nas discussões e justificativas para as reformas e melhoramentos por que passaram muitas cidades na virada para o século XX. Desde aquelas mais importantes administrativa e economicamente nos três primeiros séculos de colonização, como o Rio de Janeiro, Salvador e Recife, até as que pouca relevância tinham na incipiente rede urbana do período colonial, como Natal, a crítica repetiu-se, homogeneamente à primeira vista, nas várias cidades em transformação, independente das particularidades das várias estruturas urbanas e da maior ou menor irregularidade dos seus traçados. Para além da questão sobre a existência ou não de planejamento por parte do colonizador português, esta tese discute como se formaram as representações sobre a cidade colonial no Brasil. Nas trilhas dessa imagem construída amiúde em negativo, aborda-se: a leitura empreendida pelos viajantes estrangeiros no início do século XIX, com ênfase no livro de Henry Koster, Travels in Bražil (1816); a problematização e instrumentalização do tema em meio às formulações higienista e sanitarista sobre a necessidade de reformar $\mathrm{e}$ modernizar o espaço urbano ao longo do século XIX; da mesma maneira, no processo de formação do campo disciplinar do urbanismo no Brasil na virada para o século XX; e, a apropriação do tema na constituição da historiografia sobre a arquitetura brasileira. Por fim, tecem-se algumas considerações sobre o texto que seria tomado como o momento fundante dessa representação: o capítulo "O semeador e o ladrilhador", de Raízes do Brasil (1936), de Sérgio Buarque de Holanda.

Palavras-chaves: cidade colonial - representações - historiografia - arquitetura - urbanismo

\section{ABSTRACT}

\section{The formation of representations on Brazilian colonial cities.}

The critique of the colonial city was one of the most usual themes on the discussion and justification of reforms and improvement plans targeted at several Brazilian cities in the turn to the twentieth century. The critique was reiterated in a virtually homogeneous fashion all over Brazil, regardless of the specific urban characteristics in each settlement, whether it was being applied to cities that concentrated great administrative and economic importance during the colonial times, such as Rio de Janeiro, Salvador and Recife, or to those that carried little relevance in the colony's fledgling urban network, such as Natal. Beyond the issue of whether the Portuguese colonizers were "planning" settlements, this thesis discusses how representations on Brazilian colonial cities came to be. As the development of this generally negative image is tracked down, this work explores the images of Brazilian cities forged by foreigner travelers, focusing on Travels in Brazil (1816), by Henry Koster; the theme's problematization by physicians and sanitary and polytechnic engineers, for whom the theme of colonial city was instrumental to demand for the urban reforms and modernization they sought over the nineteenth century; the appropriation of this theme during the process of formation of urbanism as a discipline; and in the many texts and books that delineated modern historiography on Brazilian architecture. Finally, some considerations are made on the text that could be considered the foundation for these representations: Sérgio Buarque de Holanda's "O semeador e o ladrilhador", a chapter from his 1936 work, "Raizes do Brasil".

Key-words: colonial city - representations - historiography - architecture - urbanism 



\section{SUMÁRIO}

$\begin{array}{ll}\text { Introdução } & 19\end{array}$

Primeiras cartografias de representações $\quad 25$

As partes da tese $\quad 28$

Notas sobre o conceito de representação 33

Capítulo 1

Leituras Viajantes: a cidade colonial entre olhares estrangeiros $\quad 63$

$\begin{array}{ll}\text { 1.1 Leituras formativas } & 73\end{array}$

$\begin{array}{ll}1.2 \text { O observador que participa } & 85\end{array}$

$\begin{array}{ll}1.3 \text { Narrar a cidade, viver a cidade } & 93\end{array}$

Capítulo 2

As cidades estreitas e sujas: esforços para constituição de uma (nova) ordem urbana

$\begin{array}{ll}2.1 \text { Higiene para as cidades } & 110\end{array}$

$\begin{array}{ll}2.2 \text { o traçado sanitário das cidades } & 134\end{array}$

Capítulo 3

A arte que lhe falta: legitimações do campo disciplinar do urbanismo

3.1 A primeira cidade da América do Sul

Capítulo 4

A cidade colonial na história da arquitetura: usos, indícios, e circularidades

4.1 Antiurbanismo ou as limitações impostas pelo passado 177

$\begin{array}{ll}4.2 \text { delineamentos narrativos } & 185\end{array}$

$\begin{array}{ll}4.3 \text { estudos sobre arte e arquitetura colonial } & 194\end{array}$

Considerações finais

Imagens e representações em um texto fundador 
INTRODUÇÃO 
"E se estiver na pausa e não no assovio o significado da mensagem? Se for no silêncio que os melros se falam?"

Italo Calvino, Palomar

Os textos de abertura de dois livros pioneiros e importantes sobre o estudo das vilas e cidades do período colonial brasileiro ${ }^{1}$ são significativos em suas preocupações congêneres, revelando um esforço historiográfico de discussão aprofundada, baseada em um amplo levantamento documental que abrangeu arquivos brasileiros e europeus, sobremaneira, para refutar e estabelecer novas bases para o tema.

Tanto Nestor Goulart Reis quanto Roberta Delson apontam para a imagem comum e inconteste, de conotação negativa, que até então se tinha sobre a cidade colonial no Brasil. Imagem que, diga-se, constituía-se numa premissa dos estudos de história latino-americana e dos compêndios de arquitetura: o desalinho, o enviesamento das ruas, a ocupação espontânea e aleatória, a trama urbana irregular e estreita, escura e insalubre, denunciariam a falta de ordem e de plano na sua construção, reflexo do "desleixo" português na colonização do Brasil. Como lembraria Delson, a construção de Brasília na década de 1960 representou para muitos o "início da planificação urbana formal" no país ${ }^{2}$ - o que desconsideraria até mesmo a criação de Belo Horizonte e Goiânia.

Ambos os trabalhos viriam desmontar portanto esta imagem, o caráter negativo na leitura do espaço urbano colonial brasileiro, que homogeneizara uma interpretação sobre o seu processo de urbanização e até mesmo obscurecera os

\footnotetext{
${ }^{1}$ Nestor G. Reis, Contribuição ao estudo da Evolução Urbana do Brasil 1500/1720, 2000, e Roberta Delson, Novas vilas para o Brasil-Colonia: planejamento espacial e social no século XVIII, 1997; o trabalho do professor Nestor Goulart foi apresentado em 1964 e conheceu sua primeira edição em 1968, pela Livraria Editora Pioneira; o livro de Delson foi publicado originalmente em inglês, em 1979.

Observação: optamos por uma entrada simplificada, em nota de rodapé, das referências completas que se encontram no final desta tese, permitindo assim saber desde logo quem é o autor e qual o título da obra; assim, nem nos limitamos ao sistema autor-data, nem nos estendemos demais para anotar todas as informações bibliográficas. Esse procedimento foi adotado ao longo de toda a tese.

${ }^{2}$ R. Delson, op. cit., p.xi.
} 
vários exemplos de novas comunidades planejadas no século XVIII. Primeiro, dando a lume alguns planos urbanísticos dos dois primeiros séculos de colonização - em especial o que orientou a criação de Salvador ainda na primeira metade do século XVI - e o processo social de ocupação do território, ao qual certa preocupação com o ordenamento urbano esteve desde o princípio vinculado, quer em traçados regulares ou não; ${ }^{3}$ em segundo lugar, deslindando o amplo programa de criação de vilas e cidades para o "sertão" do Brasil durante o Setecentos, uma clara política urbana dos administradores portugueses para expandir e garantir o controle da Coroa sobre a colônia; ademais, a regularidade e a homogeneidade dos novos espaços seriam também expressão do pensamento racional iluminista e absolutista europeu e indutores de novos padrões culturais e sociais. ${ }^{4}$

Outros estudos avançaram nessas questões, colocando novos elementos na discussão sobre a existência de um processo de ordenamento e de planificação portuguesas na sua maior colônia ultramarina, desde um chamado "urbanismo vernacular" português no interior, passando pela definição dos diversos agentes modeladores do espaço urbano, em especial o papel do almotacé e do engenheiro militar, até a relação entre a forma urbana e as tecnologias de guerra. ${ }^{5}$ Contudo, se todos esses estudos têm demonstrado que de fato houve planejamento na criação de muitas vilas e cidades desde o século XVI, e não apenas sob o governo absolutista do Marquês de Pombal, o que evidenciaria uma política urbanizadora para a América Portuguesa, permanece em aberto a questão sobre a formação dessa representação sobre a cidade do período colonial no Brasil. Afinal, como essa imagem se forma e adquire caráter historiográfico? Quais as suas raízes e quais as suas repercussões no estudo e, conseqüentemente, na transformação das cidades brasileiras? Como ela assume um viés predominantemente negativo que, como afirmaria Nestor Goulart,

\footnotetext{
${ }^{3}$ N. G. Reis, op. cit.

${ }^{4}$ R. Delson, op. cit.

${ }^{5}$ Como exemplo no avanço nas discussões sobre a cidade colonial brasileira, basta ver o crescente interesse e número de trabalhos sobre o tema nos últimos Seminários de História da Cidade e do Urbanismo, em especial a partir da IV edição (Rio de Janeiro, 1996), dos quais fizemos aqui algumas referências. A esses, somem-se pesquisas recentes que se constituem referências fundamentais para esta discussão, como: Laurent Vidal, Mąagão, 2008; Amílcar Torrão, A arquitetura da alteridade: a cidade luso-brasileira na literatura de viagem (1783-1845), 2008; Rodrigo Baeta, Ouro Preto cidade barroca, 2003; Beatriz Bueno, Desenho e Desígnio, 2001; Manuel Teixeira e Margarida Valla, O urbanismo português: séculos XIII-XVIII, 1999.
} 
desqualificaria os "núcleos urbanos brasileiros como objeto de estudo"? Estas são algumas das questões que moveram os interesses das pesquisas que fundamentam esta tese desde o início.

Responder a tais questões não é obviamente o interesse dos estudos acima citados, voltados que estão ao problema da interpretação dos significados da colonização portuguesa, na qual a forma das cidades - e a condução ou não no seu processo de construção - constitui-se como uma das expressões mais fortes. De forma esquemática, pode-se afirmar que a oposição se coloca entre aqueles que defendem a existência de uma clara política de urbanização portuguesa para o Brasil, expressa em modelos, ordenamentos e planos, e aqueles que a negam ou diminuem a sua importância frente ao poder do mundo rural ou às especificidades da colonização lusitana.

Cabe aqui abrir um parêntese: ao discutir os estudos sobre as cidades coloniais no Brasil, Paulo Santos identificaria três enfoques que estruturavam essa discussão: o primeiro, tributário da oposição semeador-ladrilhador de Sérgio Buarque, enfatizaria o desleixo do colonizador português; o segundo leria com complacência a suposta ingenuidade canhestra das soluções do povoador; o terceiro elogiaria a diligência e o sinal de progresso das cidades construídas a partir de traçados regulares. Insatisfeito com tais enfoques, Santos proporia um quarto: reconhecer a genuinidade das cidades de traçado irregular como herdeiras de um outro sistema de conceitos urbanísticos, que remontariam à Idade Média. ${ }^{7}$ Antes ainda, o crítico de arte Maria Barata, durante sua exposição na primeira sessão (dedicada ao tema da "Cidade nova") do Congresso Internacional Extraordinário de Críticos de Arte, em 1959, afirmaria que "mesmo construídas de acordo com tradição medieval lusa, essas primeiras cidades brasileiras parecem ter tido traçado original mais regular e ortogonal do que geralmente se supõe”. A expansão posterior,

\footnotetext{
${ }^{6}$ N. G. Reis, op. cit., p.13.

7 Paulo Santos, Formação de cidades no Brasil colonial, 2001 [1968]; Cf. também a revisão bibliográfica de A. Torrão Filho, Imagens de pitoresca confusão: a cidade colonial na América Portuguesa, Revista USP, 2003. Não se pode deixar de mencionar que tanto "Formação" quanto "Quatro séculos de Arquitetura" (1965) são posteriores à participação de Santos na banca de livre-docência do professor Nestor Goulart.
} 
descendo as acrópoles originais de defesa dos sítios, é que teria acentuado as irregularidades. ${ }^{8}$

Seguindo a exposição de Roberta Delson e Nestor Goulart, estariam na segunda categoria alguns autores como Robert Smith, Richard Morse e Henrique Mindlin, aqueles para quem "a ordem era ignorada pelos portugueses" (a frase é de Smith, em “Arquitetura colonial”, de 1955). Poder-se-ia acrescentar ainda entre esses Yves Bruand. Quando o paleógrafo francês concluiu o seu amplo panorama sobre a arquitetura brasileira do século XX, a primeira edição do livro de Nestor já era conhecida no meio acadêmico; contudo, considerando o exemplo da planificação de Salvador inconsistente, embasar-se-ia em Sérgio Buarque (no que diz respeito ao tipo de cidades criadas pelos portugueses, em oposição aquele dos espanhóis) para afirmar que "o urbanismo português foi mais negativo do que positivo em relação à tarefa de planificação...".?

Estaria aí, portanto, a oposição básica e fundamental que, diga-se, tem fomentado algumas importantes discussões e controvérsias no campo disciplinar da história urbana, da arquitetura e, principalmente, do urbanismo. A polêmica de fundo, congênere aos dois estudos iniciais já citados, abre-se a partir do capítulo "O semeador e o ladrilhador”, do clássico Raízes do Brasil, no qual Sérgio Buarque trabalha com a "metodologia dos contrastes"10 para comparar e estabelecer as diferenças entre o empreendimento colonizador espanhol e o português em matéria de urbanismo.

A fantasia com que em nossas cidades, comparadas às da América espanhola, se dispunham muitas vezes as ruas e habitações é, sem dúvida, um reflexo de tais circunstâncias [a primazia do mundo rural, o caráter mercantil da colonização portuguesa, a maior liberalidade de sua administração, etc.]. Na própria Bahia, o maior centro urbano da colônia, um viajante do princípio do século XVIII [L.G. de la Barbinais] notava que as casas se achavam dispostas segundo o capricho dos moradores. Tudo ali era

8 Atas do Congresso Internacional Extraordinário de Críticos de Arte, Brasília, São Paulo e Rio de Janeiro, set. 1959, p.13-15.

9 Y. Bruand, Arquitetura contemporânea do Brasil, 1997, p.325; o seu livro foi fruto de uma pesquisa realizada durante a década de 1960, que resultou em tese defendida na Université de Paris IV, em 1971; foi publicado em português apenas em 1981.

10 A. Candido, O significado de 'Raízes do Brasil [1967], in Raízes do Brasil, 2006, p.237. 
irregular, de modo que a praça principal, onde se erguia o Palácio dos Vice-Reis, parecia estar só por acaso no seu lugar. ${ }^{11}$

Se a riqueza da análise concisa e sintética, mas não menos profunda e erudita, de Sérgio Buarque influenciou decisivamente estudos posteriores sobre a formação social brasileira advinda do período colonial, é inegável que o tema da cidade colonial já estava presente, bem antes da década de 1930, no meio intelectual e técnico brasileiro. Uma das representações iria tomá-la, em negativo, como a expressão material do atraso que deveria ser superado para a construção da cidade moderna no Brasil e, no fim, para a constituição de uma moderna nação.

\section{Primeiras cartografias de representações}

A crítica da cidade colonial foi um dos principais temas nas discussões e justificativas para as reformas e melhoramentos por que passaram muitas cidades na virada para o século XX, formulada por médicos, higienistas, sanitaristas, engenheiros, mas também como objeto dos ensaios e textos de caráter historiográfico. Desde aquelas mais importantes administrativa e economicamente nos dois primeiros séculos de colonização, como o Rio de Janeiro, Salvador e Recife, até as que pouca relevância tinham na incipiente rede urbana do período colonial, como Natal, a crítica repetiu-se, homogeneamente à primeira vista, nas várias cidades em transformação, independente das particularidades das várias estruturas urbanas e da maior ou menor irregularidade dos seus traçados. O engenheiro sanitarista Saturnino de Brito, por exemplo, um dos nomes mais importantes na constituição do urbanismo moderno no Brasil e cuja original e vasta obra teórica e prática teve grande ressonância no país, ${ }^{12}$ não deixou de comentar e condenar a chamada cidade antiga em muitos dos seus planos de extensão, saneamento e melhoramentos para cidades como Campos, Recife e Santos.

Deve-se afirmar, ademais, que o interesse por essa questão nasceu de certas indagações e constatações sobre o processo de transformações urbanas de Natal nos anos 1920. Trabalhando com o contraste entre as leituras histórico-literárias

\footnotetext{
11 S. B. Holanda, Raízes do Brasil, 2006 [1936], p.109.

12 Cf. C. Andrade, A peste e o Plano: o urbanista sanitarista do Eng. Saturnino de Brito, 1992.
} 
formuladas durante a Primeira República sobre a cidade colonial e a sua forma física, representada na parca iconografia existente sobre a cidade até o início do século XX, seria aventada a hipótese de que o seu processo de modernização pressupôs a construção historiográfica da (imagem da) cidade colonial. ${ }^{13}$

Isto é, a transformação física dar-se-ia não apenas sobre a trama urbana herdada do período colonial e imperial, mas principalmente sobre o conjunto de significações (negativas) do qual foi eivado este espaço: território de práticas incivilizadas e rudes, de insalubridade, de estagnação econômica, do capricho, do acaso, contra o qual era erguida e sustentada a ordem do plano urbano, produto da razão humana guiando os caminhos do futuro. Mas, poder-se-ia questionar, esse processo ocorreu apenas em Natal ou conheceu correlatos e similares em outros contextos de modernização de cidades, onde a herança urbana do período colonial era bem mais presente?

Sabe-se que Saturnino de Brito, já mencionado aqui, apoiava a sua teoria da urbanização numa leitura evolucionista do crescimento das cidades brasileiras que tinha forte correlação com o positivismo comteano. À maneira dos três estados intelectuais da humanidade, haveria três fases na vida de uma cidade, das quais a primeira era a lenta expansão do acaso colonial. Significativamente, Brito concordaria com Camillo Sitte - outra de suas grandes referências teóricas - no elogio do espaço orgânico das cidades medievais européias, mas não o faz na análise do espaço urbano do período colonial brasileiro - mesmo quando a disposição de praças e igrejas poderia ser enquadrada em exemplos sitteanos. ${ }^{14}$

No Recife, evocava-se uma ordem mítica da cidade Maurícia, fruto da presença holandesa no século XVII, que buscava legitimar, no passado, a racionalidade dos planos do urbanismo moderno do século XX. Mauriţstadt, a urbanização da ilha de Antonio Vaz, formaria então o contraste com o espaço (mal) construído pelos portugueses ao longo dos séculos. Os apólogos da modernização tentavam mostrar assim que havia no próprio passado da cidade uma vocação natural para a regularidade e a racionalidade, e não apenas as tipologias e a morfologia do

13 Cf. George Dantas, Linhas convulsas e tortuosas retificações: transformacõos urbanas em Natal nos ano 1920 , 2003, em especial o capítulo 2, "Não há-tal, Natal: movimentos de construção e desconstrução da cidade colonial".

${ }^{14}$ Essas questões serão retomadas no capítulo 2. 
espaço tradicional. ${ }^{15} \mathrm{Em}$ meados do século XIX, os elementos materiais que marcavam os usos religiosos do espaço público da capital pernambucana foram considerados, de maneira reiterada, como a expressão de um passado obscuro que deveria ser expurgado. As formas antigas eram tomadas como entraves físicos e simbólicos ao progresso. Assim, defendia-se como

Indispensável [a] demolição dos arcos de Santo Antonio e da Conceição, logo antes da abertura do trânsito. A existência desses arcos hoje é incompativel com o estado atual (...).

Pelo lado material vemos que o aumento extraordinário da edificação e aformoseamento da cidade reclama semelhante providência, por quanto esses arcos, além de impedirem o livro trânsito da grande massa de povo que por ali terá de passar, são por suas antigas formas, um completo antagonismo da atualidade, uma anomalia perfeita. ${ }^{16}$

No Rio de Janeiro, a modernização da cidade para transformá-la numa capital integrada ao circuito internacional do capitalismo comercial pressupôs a destruição a golpes de picareta da configuração sócio-espacial antiga, substituindo-a pelos referenciais ditos civilizados, importados da Belle Époque européia. ${ }^{17}$ Em São Paulo, cidade que se assemelhava a Natal no tamanho acanhado e na menor importância econômica durante o período colonial, transformar-se em metrópole significaria não somente a ruptura com os limites de fundação, o chamado Triângulo, mas a defesa da destruição dos resquícios da cidade antiga, como faria Alexandre de Albuquerque em seu plano de melhoramentos para o Vale do Anhangabaú, em $1910 .^{18}$

Percebe-se assim que a questão da cidade colonial - seus significados, sua herança - estava em disputa e em construção. Neste processo, várias referências fazem-se presentes e revelam o olhar que se volta e inquire o passado colonial. Olhares que - como toda operação historiográfica - constroem e, ao fazê-lo, selecionam, recortam, eliminam, hierarquizam. Essas referências são diversas e provêm de várias disciplinas e matrizes do pensamento, quer vinculadas à gênese do

\footnotetext{
${ }^{15}$ José Lira, Mocambo e Cidade: regionalismo na arquitetura e ordenação do espaço habitado, 1996, p. 212-225.

${ }^{16}$ Jornal do Recife, 26 jul. 1865, apud Raimundo Arrais, O Pântano e o Riacho: a formação do espaço público no Recife do século XIX, 2004, p.334-35.

${ }^{17}$ Cf. Giovana Del Brenna, O Rio de Janeiro de "Pereira Passos", 1985; e Nicolau Sevcenko, Literatura como missã: tensões sociais e criação cultural na Primeira República, 1999 [1983].

${ }^{18} \mathrm{H}$. Segawa, Prelúdio da metrópole : arquitetura e urbanismo em São Paulo na passagem do século XIX ao XX, São Paulo: Ateliê Editorial, 2000, p.16; Jose Geraldo Simões Jr, Anhangabaú: história e urbanismo, 2004.
} 
urbanismo moderno no Brasil, quer às influências teóricas (históricas, filosóficas, cientificistas, etc.) do pensamento social brasileiro.

Assim, esta tese partiu da hipótese de que a cidade moderna constituiu-se também como oposição aos chamados valores confusos, às ruas estreitas e desalinhadas, aos registros físicos de uma cidade sem ordem do período colonial. São representações que, portanto, revelariam muito mais sobre o caráter e os significados do projeto de modernização que se pretendia para o país do que sobre a própria cidade do período colonial.

Assim, quando, e.g., um importante engenheiro como Lourenço Baeta Neves atestava, na introdução às Obras Completas de Saturnino de Brito, que

(...) a realização do serviço de esgotos de Santos - onde pela primeira vez se concretizaram em larga escala ensinamentos de Saturnino de Brito - afirma de modo eloqüente e positivo a grande vitória do Brasil moderno contra o torpor colonial que abatia o seu espirito e nos colocava "numa dependência passiva da intervenção estranha" nas soluções práticas dos nossos problemas sanitários. ${ }^{19}$

entrevê-se um momento em que uma certa leitura da cidade colonial estava consolidada. Mas, que leitura é essa? É unívoca, homogênea, ou, ao contrário, resultado de uma batalha pelos sistemas de percepção e enunciação de conceitos, interpretações, leituras, imagens que, por sua vez, passam a ter valor operativo (a produzir e ou orientar "estratégias e práticas", como lembra o historiador Roger Chartier) $?^{20}$ Como se formou? e, em conseqüência, qual sua lógica narrativa, quais referências, quais palavras-chaves (com poder de síntese), quais recorrências?

\section{As partes da tese}

Interessa a esta pesquisa, então, discutir o que se reputa como o problema historiográfico da formação de uma determinada representação - negativa - sobre as vilas e cidades do Brasil colonial. Assim, a problemática, em muitos aspectos superada, sobre a existência ou não de planejamento português para suas colônias ultramarinas e, em especial, para o Brasil, é, aqui, de relevância, a princípio,

\footnotetext{
${ }^{19}$ L. Baeta Neves, Introdução, in Obras Completas de Saturnino de Brito, v.1, 1943, p.xv.

$20 \mathrm{O}$ conceito de representação será discutido na nota final à introdução.
} 
secundária - e quando ajudam a cartografar essa representação, seus lugares-comuns e fundos-comuns.

Quais os elementos formativos, quais as matrizes do pensamento que informaram e influenciaram a construção historiográfica sobre a cidade colonial no Brasil? Quais representações se formam para além da longeva e quase inconteste imagem negativa que se lhe foi atribuída? Um problema de fundo historiográfico, como dito, que, defende-se, pode ser revelador das estratégias de legitimação e justificação de diversos saberes modernos em emergência e consolidação no Brasil.

Para enfrentar esse problema, foram propostos três eixos investigativos para tentar deslindar os possíveis emaranhados na construção da narrativa historiográfica sobre a cidade colonial, procurando identificar sobreposição de teses e argumentos, diálogos entre textos de campos disciplinares distintos, referências comuns, etc. O primeiro eixo aborda o que se chamou aqui de matriz higienista/sanitarista, enfatizando as representações oriundas da emergência do saber médico e do papel reformador do engenheiro sobre a cidade, ao longo do século XIX e das primeiras décadas do século XX. O segundo eixo discute a matriz urbanística, acompanhando de perto as representações provenientes da consolidação de uma disciplina que arrogaria autoridade, autonomia e especificidade para transformar, reformar, derrubar a cidade e seu legado urbano do período colonial (que, seguindo essa formulação, adentraria e marcaria o período imperial). $O$ terceiro eixo inquire a formação da historiografia da arquitetura no Brasil no século XX - ao tomar as relações com o passado como moto explicativo fundamental, permitiu reconstruir uma ou mais das possíveis genealogias das representações que aqui se problematizam, perceber referências que se repetem, palavras que emulam ou que deslizam semanticamente.

Eixos que, invariavelmente, remetem-se, direta ou indiretamente, crítica ou acriticamente, aos relatos dos viajantes estrangeiros que vieram ao Brasil desde o século XVI e, em especial, aqueles que testemunhariam a aceleração do processo de transformações por que a ainda colônia passaria a partir do início do século XIX. Afinal, o "olhar de fora" foi fundamental para a conformação das maneiras como se leu e como se deu a ler as paisagens natural, urbana e cultural do Brasil, implicando na construção do próprio "olhar de dentro", do conhecimento e das formas de ler e 
narrar o passado do país ${ }^{21}$ - nesse sentido, é significativo que o marco inicial da historiografia brasileira seja o ensaio de Carl Friedrich von Martius (autor da longa e abrangente "Viagem pelo Brasil", ao lado de Johann Baptiste von Spix), vencedor do concurso promovido pelo Instituto Histórico e Geográfico Brasileiro e publicado em 1845, intitulado "Como se deve escrever a história do Brasil”. Martius não escreveu tal história, mas os princípios de seu ensaio teria larga circulação entre os próprios membros do IHGB, desde a História de Varnhagen. ${ }^{22}$

Assim, a presente tese parte, no capítulo 1, da discussão sobre a leitura acerca das cidades coloniais luso-brasileiras que seriam construídas pelos viajantes estrangeiros no início do século XIX, enfatizando o livro Travels in Brąil, de Henry Koster, publicado em Londres em 1816. Apenas um livro para construir generalizações, encontrar respostas e delimitar os elementos constitutivos da representação que esta tese persegue? Não há tal pretensão. Aqui, mais do que nos outros capítulos, reconhecem-se as limitações que se enfrenta forçosamente ao tentar articular tramas e formulações derivadas de diversos campos de conhecimento.

Assim, foi necessário o trabalho constante com fontes secundárias e compilações, seletas de texto, etc., para contemplar um conjunto amplo e variado de áreas de interesse que, reconheça-se, amiúde se cruzam. Entretanto, isso não implica a desconsideração das fontes primárias, do acesso direto - e sempre que possível físico e não apenas virtual - aos documentos originais, às edições originais. Enfatizar tal dimensão explica-se porque, e.g., ao propor abarcar as representações de cidade formuladas pelo "olhar de fora" não se é possível - no âmbito de uma pesquisa de doutorado que não as tem como objeto principal - abarcar todos os documentos originais da miríade de relatos deixados pelos viajantes durante o século XIX (e, vejase, tal recorte já aponta para uma circunscrição dentro de uma produção que remonta, com muitos exemplos, ao século XVI). Assim, o acúmulo de releituras e discussões sobre o tema torna-se ainda mais fundamental, ${ }^{23}$ ajudando a iluminar o

21 Ana Maria Belluzzo, O Brasil dos viajantes, 1999; Flora Sussekind, O Brasil não é longe daqui, 1990.

22 Amílcar Torrão Filho, $A$ arquitetura da alteridade: a cidade luso-brasileira na literatura de viagem (17831845), 2008, p.249 et seq.

23 Nesse sentido, os textos já citados de Amílcar Torrão Filho (2008) e de Ana Maria de Moraes Belluzzo (1999) foram referências importantes, abrindo-nos portas e apontando possibilidades de análises e mesmo possíveis conclusões. 
próprio texto de Koster e a compreendê-lo dentro de uma rede de significações sobre o tema no período.

O capítulo 2 aborda o primeiro eixo de análise proposto, procurando mapear como o tema do passado das cidades foi tematizado pelos profissionais que se debruçaram sobre as transformações por que os espaços urbanos brasileiros passaram ao longo do século XIX. A ênfase inicial considera a ótica higienista e, principalmente, a cidade do Rio de Janeiro, porque seria onde os esforços mais sistemáticos foram feitos (e por alguns dos principais profissionais, aqueles que fizeram parte do círculo real e imperial) e onde primeiro foram discutidos. $\mathrm{Na}$ segunda parte do capítulo, aborda-se a instrumentalização do tema da cidade colonial pelas formulações do urbanismo sanitarista, que, desde fins do século XIX, vinha tecnicalizando as discussões higienistas e apontando caminhos decisivos para a formação do campo disciplinar do urbanismo no Brasil. ${ }^{24}$

O capítulo 3 propõe discutir um momento específico e fundador das discussões sobre o urbanismo no Brasil - embora assim ainda não se nomeasse: o processo que levaria à fundação de Belo Horizonte na década de 1890, considerando em especial os documentos da Comissão, liderada pelo engenheiro Aarão Reis, que escolheria, dentre cinco localidades preestabelecidas, o antigo arraial de Curral d'El Rei. $^{25}$

Para o capítulo 4, trabalhou-se com a hipótese de considerar os textos constituintes da historiografia da arquitetura brasileira como, de certa maneira, ensaios de interpretação do Brasil. Assim, ao mobilizar temas de fundo - como o da cidade colonial - para construir a leitura sobre o objeto principal do ensaio, várias palavras, expressões, exemplos e conceitos são utilizados, permitindo mapear quais referências eram explicitadas, diretamente ou não, e como eram mobilizadas, iluminando, assim, linhas narrativas que retrocedem, e.g., de Yves Bruand para Fernando Azevedo, desse para Gilberto Freyre e, desse, para o relato de muitos

\footnotetext{
${ }^{24}$ Para esta segunda parte, os trabalhos do professor Carlos de Andrade (1992 e 1996) serviram como pontos de partida importantes.

${ }^{25}$ A compilação de Abílio Barreto (1996), reeditada por ocasião do centenário de Belo Horizonte, e os textos da pesquisadora Heliana Salgueiro $(1997 ; 2001)$ foram um suporte fundamental para construção desse capítulo.
} 
viajantes, que, a exemplo de Henry Koster, pousaram no Brasil na primeira metade do século XIX, dentre muitas outras fontes. ${ }^{26}$

Por fim, estabelecem-se algumas considerações sobre aquele texto que, ao longo desta pesquisa, serviu como ponto de partida para as indagações que a fundamentam e transformaram-se em ponto de inflexão - quando das inescapáveis críticas e auto-críticas sobre a pertinência da problemática acerca das representações sobre a cidade colonial no Brasil, i.e., questionar se tais representações foram de fato tão longevas e, mais importante, se foram extensivas, homogêneas, operativas. Assim, pensar como o texto "o semeador e o ladrilhador", do clássico Raízes do Brasil, de Sergio Buarque de Holanda, ajudou a construir e a consolidar o estatuto historiográfico dessas representações (principalmente a partir das revisões da segunda edição, de 1948), mesmo que fundamentando debates e querelas que lhe escapavam, conformam o ponto de chegada desta tese.

Assim, há que se fazer algumas advertências sobre esta tese. Antes de mais nada, deve-se reconhecer as limitações inerentes ao enfrentamento de um problema historiográfico que comporta muitas sobreposições, tramas diversas, uma genealogia no mais das vezes difusa, que parece escapar das mãos do investigador envolvido com muitas fontes primárias e secundárias e sem recorte temporal muito preciso.

A narrativa que articula essas preocupações, organizada nos quatro capítulos já explicitados, não pretende montar linhas de continuidade de representações, dos lugares-comuns e dos fundos-comuns, mas elas se impõem vez ou outra, como se poderá perceber. O texto é, em alguns momentos mais fragmentário, quase episódico, em outros, há mais fluidez na narrativa. De fato, o interesse fincou-se em cartografar ênfases, usos reiterados, indícios, circulações e mesmo mudanças de significações de palavras, cortes específicos em relação a uma crescente construção da leitura da cidade antiga, da cidade do passado, da cidade colonial brasileira.

Desta maneira, não interessou especificamente, e.g., fazer uma história da literatura dos viajantes no Brasil, mas mapear/cartografar/descobrir as peças de um quebra-cabeças imenso e incompleto; outrossim, não interessou fazer uma história da medicina ou da higiene pública no Brasil ou mesmo da estruturação da engenharia

26 A dissertação do professor Carlos Martins sobre a formação da trama narrativa hegemônica da historiografia da arquitetura brasileira deu-nos a moldura para começar a compor esta capítulo. 
sanitária. Ao tomar como campo de atuação principal a cidade, pode-se acompanhar a construção narrativa de justificativas e legitimidades para a ação profissional, como se nomeou e equacionou o problema a ser enfrentado - e a cidade existente foi, claramente, transformada em problema.

Talvez a imagem do quebra-cabeça de Ginzburg e Prosperi, conforme narra Manfredo Tafuri na introdução ao livro "A esfera e o labirinto" (quando expõe uma espécie de suma do seu projeto e método de investigação), seja apropriada para aclarar essas limitações para enfrentar um problema que é eminentemente historiográfico - mas que, óbvio, se rebate nas práticas culturais e materiais que transformam e significam a cidade. Em determinado momento, as peças acumuladas nos caminhos tortuosos e complexos do curso labiríntico da análise histórica, começam a se juntar e a fazer sentido - podem ser colocadas, uma a uma, agrupadas; contudo, ao contrário do jogo, nem a imagem a ser composta é apenas uma e nem mesmo todas as peças estarão a mão. ${ }^{27}$

Crê-se assim que esta tese conseguiu juntar peças diversas em torno do problema aqui exposto, algumas compondo áreas maiores, outras dispersas em torno de uma idéia, uma palavra, uma sugestão a partir de um texto obscuro ou de menor importância dentro de tramas disciplinares hegemônicas. Outras áreas ficaram como lacunas explícitas - e, acredita-se, de significativas possibilidades (como as representações na literatura, na pintura histórica do século XIX ou na das vanguardas artísticas brasileiras do início do século XX).

\section{Notas à introdução: sobre o conceito de representação}

Preâmbulo

Palomar, personagem irrequieto, meditabundo e nervoso de Calvino, põe-se a nadar num final de tarde ensolarado. A superfície ondulada e acobreada do mar excita o vislumbre do reflexo do sol que o acompanha - é a "espada do sol” que se forma continuamente, inexoravelmente, entre o observador e a manifestação ótica da existência física do astro.

\footnotetext{
${ }^{27}$ M. Tafuri, Introducción: el proyecto histórico, In La esfera y el laberinto: vanguardias y arquitectura de Piranesi a los años setenta, 1984, p.05.
} 
Em um processo de contínuo questionamento, Palomar pensa sobre o seu lugar no mundo, sobre o lugar do homem no mundo. Existiria o sol sem alguém a nomeá-lo? a observá-lo? Se a projeção dos raios solares segue o olhar de cada nadador-observador, continuariam então a existir sem o olho que a vê? Essa inquietude leva o personagem a afirmar:

Tudo isso acontece não no mar, nem no sol', pensa o nadador Palomar, 'mas dentro de minha cabeça, nos circuitos entre os olhos e o cérebro. Estou nadando em minha mente; é apenas ali que existe essa espada de luz; e o que me atrai é precisamente isto. $^{28}$

O sol que refulge, brilha e segue, refulge sobre algo, brilha para alguém, segue algo. Depende daquele que o observa e nomeia a condição de refulgir, de brilhar, de seguir. Se o reflexo é uma construção interna, não haveria outra conclusão possível: “Todo o resto é reflexo entre reflexos, inclusive eu". ${ }^{29}$ O silogismo resulta lógico para Palomar. O que lhe força a desdobrar o raciocínio num emaranhado relativista:

Seu olhar voltado para cima contempla agora as nuvens vagantes e as colinas nebulosas dos bosques. Seu eu também está ao revés nos elementos: o fogo celeste, o ar que corre, a água que berça e a terra que sustenta. Seria isso a natureza? Mas nada do que vê existe na natureza: o sol não se põe, o mar não tem aquela cor, as formas não são as que a luz projeta na retina. (...). A natureza não existe?30

Armadilha retórica que o incomoda e que não sobrevive ao primeiro sinal da presença humana. Um barco irrompe e turva o mar. Espalha resíduos de óleo e fumaça. Outros detritos são revelados pela baixa-mar. Palomar, o homem, detrito entre detritos, que se chocam, se misturam, não pode mais negar a existência, ainda que insuportável, daquilo que está para além de si.

28 Italo Calvino, Palomar (conto "A espada do sol”), 1994, p.16 (a referência completa desta e das demais notas de rodapé estão listadas ao final). Esse conto foi publicado originalmente em $L a$ Republica, Roma, 29 jun. 1983 (cf. Valéria Arauz, Lentes de Palomar, 2002).

${ }^{29}$ Calvino, op. cit., p.17.

30 Ibidem, p.17-18. 
Em meio à polifonia que marca os discursos internos dessa reflexão (cujo pêndulo toca tanto a negação quanto a descrição ferina do real), Palomar, por fim, convence-se de algo. ${ }^{31}$

Pensando bem, tal situação não é nova: já durante milhões de séculos os raios de sol pousaram sobre a água antes que existissem olhos capazes de recolhê-los.

(...). Um dia o olho saiu do mar, e a espada, que já estava ali a sua espera, pôde finalmente ostentar toda a esbelteza de sua ponta aguda e seu fulgor cintilante. Tinham sido feitos um para o outro, a espada e o olho: e talvez não tenha sido o nascimento do olho que tenha feito nascer a espada, mas vice-versa, porque a espada não podia recusar um olho que a observasse de seu vértice.

$[\ldots]$.

(...). Está convencido de que a espada existirá mesmo sem ele. ${ }^{32}$

Construindo-se como uma metanarrativa que problematiza tanto a natureza quanto a confiabilidade da percepção, da capacidade de o homem descrever e explicar aquilo que vê e vivencia (e, em conseqüência, como "reflexão acerca do próprio ato de ler"), o final do conto aqui citado expressa aquilo que os fenomenologistas chamam de o "a priori do mundo". 33

Esse texto de Calvino serve assim como entrada e provocação ao temas das representações na historiografia. Afinal, e aparentemente enredados numa trama sem fim de referências, a qual nível de realidade e ou verdade aspira o historiador? Ou, afinal, o que cantam as sereias? ${ }^{34}$

\footnotetext{
31 Diga-se, a propósito, que o movimento pendular, sempre em suspenso, é comum nos demais contos que compõem a obra, à exceção desse conto "A espada do sol" e de "Lua do entardecer" (Cf. Arauz, Lentes de Palomar, 2002, p.58-63, 91).

32 Calvino, Palomar, 1994, p.18-19, grifos nossos.

33 "a priori of the world, its status as always, already there" (J. Cannon, Calvino's lattest challenge to the Labyrinth..., Italica, 1985, p.191); a sugestão de ler Palomar como uma metáfora do olhar da linguagem, como uma metanarrativa sobre o próprio ato de ler, é de V. Arauz, op. cit., p.82-88.

${ }^{34}$ Ao discutir os usos da literatura e, portanto e mais especificamente, as obras de ficção, Calvino propõe uma diferenciação entre o "nível de realidade" (que diz respeito ao mundo da obra, within the work) e o "nível de verdade" (que se refere ao mundo externo à obra), ambos importantes para construir uma compreensão do universo da escrita. A fórmula que sintetiza esses vários níveis que interpenetram o texto está na asserção "I write that Homer tells that Ulysses says: I have listened to the song of the Sirens" (cf. Calvino, Levels of reality in literature, The uses of literature, 1986, p.103, 108, 111-119).
} 


\section{Introdução}

O pesquisador da Escola de Administração Pública da University of South Califórnia, Robert Daland, viajou ao Brasil, no verão de 1965, para realizar as pesquisas de campo que fundamentariam a publicação do livro "Brą̧ilian Planning", em 1967. Das suas investigações e entrevistas com personalidades como o exMinistro do Planejamento Celso Furtado, os professor Candido Mendes e Nelson Mello e Souza, além do contato com a Fundação Getúlio Vargas, resultaria um esforço de compreender as relações entre planejamento lato sensu e o processo de desenvolvimento dos países - no caso, a partir do estudo específico do Brasil, "which has a twenty-year history of conscious, institutionalized, central planning". 35

Dos estudos empreendidos por Darland - sobre o conjunto de planos do governo federal desde o Estado Novo e, principalmente, desde o Plano de Metas de Juscelino Kubitschek - interessa aqui sobremaneira o ponto de partida para entender a história do planejamento no Brasil. Observe-se o trecho a seguir, que abre o capítulo 2, intitulado "The history and context of Brazilian Planning":

Central government planning has come to Brazil, not because of any innate sense of rationality and order such as that attributed to Germany, or because of a statist ideology as in the Soviet Union, or yet because of any crisis of survival in a hostile world as in Israel. In many respects, on the contrary, the temperament and values of the Brazilian people do not accept the order, efficiency, and the rationality which planning implies. ${ }^{36}$

Significativas, apesar de lacunares, tais afirmações são indícios de um conjunto de representações sobre o Brasil (como nação, como povo, como cultura, como história) que marcou - e, talvez se possa afirmar, ainda marca - parte significativa da sua produção historiográfica. ${ }^{37}$ Que representações são essas que se insinuam em algumas palavras chaves (ou, melhor, como propõe a filósofa Myriam D'Allones, lugares-comuns) $?^{38}$ Em que registro operam? Palavras que funcionam,

\footnotetext{
35 Robert Darland, Brazilian planning, 1967, p.01; cf. também o "Preface".

${ }^{36}$ Ibidem, p.12; grifos nossos.

37 Não poderemos aprofundar esse tema (da permanência de algumas representações) aqui, mas apenas indicar uma importante leitura a respeito: Maria Stella Bresciani, O charme da ciência e a sedução da objetividade, 2005.

38 Myriam R. D’Allones, Le dépéressiment de la politique, 1999; devo essa indicação à leitura de Bresciani, op. cit., p.41 ; o lugar-comum [é] constituído por palavras, crenças, opiniões ou mesmo preconceitos que têm significado para uma "comunidade política efetiva" e que, mesmo confusas, erráticas e sem
} 
diga-se desde logo, como registros de ausências: o brasileiro não aceitaria a ordem, a eficiência, a racionalidade; ou, mais ainda, tais elementos - essenciais à cultura do planejamento, como o brasilianista ressalta - não se encontrariam inscritos em sua história.

Darland não as inventa ou propõe, é claro. Tampouco se apóia em fontes primárias para construir tais afirmações. Apóia-se, sim, em um conjunto de autores que cita direta ou indiretamente (como se revela na lista muito mais longa da selected bibliography do que nos usos ao longo do texto). Fernando Azevedo, Gilberto Freyre, Nelson W. Sodré, José Honório Rodrigues, Vianna Moog, além do próprio Celso Furtado e de outros autores, compõem o seu quadro de leituras de "interpretação do Brasil”. Daí certamente advém o seu repertório de representações e lugares-comuns

Representações que não são necessariamente homogêneas - embora compartilhem, amiúde, lugares-comuns, interpretações, idéias e palavras chaves, a exemplo dessa imagem em negativo (de falta de ordem, eficiência, racionalidade), uma das representações mais correntes e significativas (com clara dimensão operativa), defende-se aqui como hipótese, sobre a história do Brasil e, mais especificamente, sobre o passado de suas cidades.

Investigar o processo de formação das representações sobre a cidade colonial no Brasil pressupõe deslindar uma trama muitas vezes emaranhada e difusa em várias matrizes do pensamento e de tradições intelectuais e profissionais do Brasil, seus lugares-comuns, seus pontos de convergência e de dissensão, suas lógicas narrativas. Mais ainda, tal investigação implica, do ponto de vista metodológico, pôr em questão o próprio conceito de representação - seus usos, possibilidades e problemas para a história da cidade e do urbanismo.

Para tanto, toma-se como ponto de partida a leitura de textos-chaves do historiador francês Roger Chartier - aquele que talvez mais diretamente tenha retomado e defendido o conceito de representação e, assim, ajudado a estruturar a chamada "nova história cultural". ${ }^{39}$ Ademais, por intermédio de Chartier é possível

precisão, deitam raízes na vida e na experiência das pessoas; o fundo-comum é o repositório das idéias, noções, etc., que subsidiam análises, interpretações. Isto é, o lugar-comum é a "imagem resultante, [e o] fundo-comum o material com o qual é elaborada e cuja genealogia necessita ser interrogada".

39 O professor Ciro Cardoso aponta o papel central de Chartier na conformação da "nova história cultural", cf. Ciro F. Cardoso, Introdução: uma opinião sobre as representações sociais, in 
ler em diálogo (direto e indireto) autores como Pierre Bourdier e Carlo Ginzburg, além de vários comentadores, atento às questões e métodos que permitem uma investigação do passado suspenso no delicado equilíbrio entre, por um lado, o reconhecimento de que a narrativa é construída pelas questões postas e repostas a cada momento e por cada pesquisador; e, por outro, a possibilidade de tornar o passado inteligível pela sua (do passado) própria utensilagem mental (conceito-chave que Chartier toma emprestado de L. Febvre) ou habitus (de Norbert Elias), i.e., pelos seus próprios limites, materiais, escolhas.

Articula-se, ainda, a discussão sobre o conceito de representação às noções de lugar-comum e fundo-comum, como as define D'Allones, como suporte analítico para compreender diacronicamente a construção e ou uso de imagens recorrentes que formam, conformam ou sustentam as representações.

Estas notas não têm pretensões de esgotar a discussão ou mesmo de abarcar os múltiplos aspectos e campos disciplinares que utilizam o conceito (como na Filosofia, na Psicologia, na Ciência Cognitiva). ${ }^{40}$ Intenta-se, sim, mapear alguns dos pontos principais das discussões que se articularam em torno do conceito com o intuito de problematizar o campo disciplinar da história da cidade e do urbanismo.

\section{Por uma bistória cultural}

$\mathrm{Na}$ introdução à coletânea de artigos sobre "A história cultural", Chartier coloca desde logo o lugar central que o conceito de representação teria para uma nova abordagem na prática historiográfica. Como "pedra angular", as representações permitiriam discutir e articular três maneiras com que se constroem as relações com o mundo social, a dizer: ${ }^{41}$ 1) as operações de classificação e delimitação que os grupos sociais utilizam para construir e ou apreender a realidade; 2) as práticas que implicam (e que fazem reconhecer) uma identidade social, que estruturam uma maneira de estar no mundo e que significam (simbolicamente) uma posição e um estatuto; e 3) as

Representações: contribuições a um debate transdisciplinar, 2000, p.12; cf. também J. Devald, Roger Chartier and the fate of cultural history, French Historical Studies, 1998.

40 Para tanto, sugiro a leitura dos artigos que compõem a coletânea organizada pelos professores Cardoso e Malerba, Representaçoes: contribuições a um debate transdisciplinar, 2000; cf. também M. Alexandre, Representação social: uma genealogia do conceito, Comum, 2004.

${ }^{41}$ R. Chartier, Introdução: por uma sociologia histórica das práticas culturais, In A História Cultural, 1988, p.23. 
formas objetivas e institucionais por meio das quais os representantes (coletivos ou singulares) marcam e perpetuam sua existência (do grupo, classe ou comunidade).

Mas, o que seriam as representações para Chartier? Antes de mais, diga-se, não conformam uma palavra ou conceito que desempenha o mesmo lugar analítico de "ideologia" ou "mentalidades". De fato, os artigos reunidos na coletânea supracitada expressam, como afirma o próprio autor, uma insatisfação com a história francesa das décadas de 1960 e 1970, fortemente marcada pela noção das mentalidades e pela abordagem serial, quantitativa. ${ }^{42}$

Note-se que não há nenhuma pretensão em desqualificar essas vertentes historiográficas. Ao contrário, Chartier reconhece a importância e filia-se à herança dos Annales - embora invertendo pressupostos estruturais e recuperando o que chamaria de as "inspirações fundadoras" dos anos 1930 (como a noção de "utensilagem mental", de Lucien Febvre). O que o incomoda seria a incapacidade de enfrentar os impasses que novas disciplinas trouxeram ao campo da História, pondo em xeque tanto objetos quanto certezas metodológicas.

A história das mentalidades, afirma Chartier, teria se construído, de maneira geral, buscando fundar-se nos mesmos critérios de inteligibilidade da história econômica e social (i.e., atenta às estruturas na longa duração, aos números e quantificações, às repetições encontradas nas séries, etc.). Não à toa, Le Goff apontaria que a história das mentalidades foca a atenção no "quantitativo cultural". Busca, assim, pelo que escapa aos "sujeitos particulares da história, porque revelador do conteúdo impessoal de seu pensamento". ${ }^{43}$ Isso teria gerado alguns problemas aos quais Chartier resumiria sob o epíteto do "primado quase tirânico do social". ${ }^{44}$

Tal primado implicava - como premissa analítica - uma série de enquadramentos que impediam a atenção às formas de apropriação (de idéias, objetos, modelos culturais, representações, etc.), quer individuais, quer de um grupo mais específico. Relacionava-se, assim, quase mecanicamente, grupos sociais a níveis

\footnotetext{
${ }^{42}$ R. Chartier, A História Cultural, 1988, p.13-14, 40-44; sobre a crítica à abordagem quantitativa da história, em especial a cultural, e a retomada da narrativa, Cf. P. Burke, A Escola dos Annales, 1997, p.93-107.

${ }^{43}$ J. Le Goff, As mentalidades: uma história ambígua, in História: novos objetos, 1988, p. 71.

${ }_{44}$ R. Chartier, A História Cultural, 1988, p.45; essa discussão está presente também em Idem, “O mundo como representação", Estudos Avançados, 1991.
} 
culturais; distinções sociais (por renda, profissão, etc.) a diferentes sistemas de pensamentos - sem considerar tensões internas, e.g. Mais ainda, a noção de mentalidades considerava e investigava principalmente os pontos comuns de um indivíduo com os demais homens e mulheres de seu tempo - por mais extraordinário que tenha sido esse sujeito. Daí, inclusive, como já alertaram Carlo Ginzburg e Peter Burke, a redundância de apor o adjetivo coletivas a mentalidades. ${ }^{45}$

Quais as mentalidades dos engenheiros sanitaristas envolvidos com as reformas urbanas da virada para o século XX no Brasil? A identificação de pontos comuns, conquanto importantes, seriam suficientes para discutir atuações específicas de indivíduos ou para construir histórias urbanas atentas às escalas locais e regionais? A noção positivista de progresso que permeia a formação de tantos politécnicos, desde André Rebouças até Aarão Reis ou Francisco de Paula Souza, dentre muitos, explicaria os vários projetos de construção do território nacional (por meio das infraestruturas de suporte às atividades produtivas) na segunda metade do século XIX?

Listam-se essas questões - sem a pretensão de respondê-las - para traçar um paralelo com as inquietações levantadas por Chartier em prol da necessidade de construção de um esforço metodológico e conceitual que aponte para uma abordagem, sem reduções deterministas, das "relações entre sistemas de crenças, de valores e de representações, por um lado, e de pertenças sociais, por outro". ${ }^{46}$

Se é certo que, por um lado, a compreensão das mentalidades dos grupos sociais (no caso, de círculos profissionais, se pensarmos nos engenheiros politécnicos) é importante para compreender processos de institucionalização, de organização de saberes e poderes, além dos repertórios de abordagens e construção de soluções técnicas - o "horizonte de possibilidades latentes" do qual fala Carlo

\footnotetext{
45 C. Ginzburg, O queijo e os vermes, 2005, p.28; Peter Burke, Abertura: a nova história, seu passado e seu futuro, in A Escrita da História, 1992. Não se pode esquecer que, já na década de 1970, Le Goff apontava para os potenciais e, ao mesmo tempo, para as dificuldades da história das mentalidades em meio a objetos e fontes de pesquisa difusos, a pontos e lugares-comuns, a elementos de repetição do cotidiano, dos textos, dos monumentos, etc., enfim, ao chamado "quantitativo cultural"; não deixava também de ressaltar a necessidade de ficar atento às especificidades de cada forma de expressão "mentalidade não é reflexo", diria - e de manter uma relação estreita com a história da cultura, levando em conta o "equipamento intelectual" no qual as mentalidades se formam, se desenvolvem e vivem, cf. J. Le Goff, As mentalidades: uma história ambígua, in História: novos objetos, 1988 [ed. orig. 1974].

${ }^{46}$ R. Chartier, A bistória cultural, 1988, p.53.
} 
Ginzburg; ${ }^{47}$ por outro, será preciso ficar atento às idiossincrasias, aos movimentos individuais, para entender como os "motivos intelectuais" e ou as "formas culturais" são apropriados, como circulam, como se enraízam e (se quisermos seguir a metáfora) como dão novos frutos. ${ }^{48}$

Por exemplo, e sem nos aprofundarmos muito, não se pode entender a circulação da noção de cidade-jardim no Brasil (ou, se quisermos, para além do seu ambiente cultural de origem, a Inglaterra do final do XIX) sem considerar as discussões pré-existentes sobre a cidade salubre no Brasil - mobilizadas desde meados do século XIX. Obviamente, não se estava falando em cidade-jardim antes do início do século $\mathrm{XX}^{49}$ Falava-se (por vários vieses, como o moralista, o econômico, o técnico, sobretudo higienista, etc.) em como construir a cidade moderna e saudável nos trópicos. Tema recorrente que encontraria nas discussões sobre a cidade-jardim um, considerava-se, sólido fundamento para a formulação de políticas e propostas de ação e de reforma urbana. Não à toa o médico Alfredo da Matta, ao levantar e descrever a topografia médica de Manaus, em 1916, propugnaria a cidade-jardim como solução para o tema no Brasil. ${ }^{50}$

E, observe-se, essa atenção às maneiras e às condições de circulação e de apropriação não implica apenas uma escolha metodológica (e conceitual ou de escala de abordagem). Implica, sim, reconhecer o papel ativo daqueles que lêem na construção do conhecimento; implica reconhecer inclusive os suportes materiais dos textos, das idéias, dos modelos culturais, além dos anteparos ou filtros prévios que conformam as maneiras das leituras.

\footnotetext{
${ }^{47}$ C. Ginzburg, O queijo e os vermes, 2005, p.25.

${ }^{48}$ Cf. Chartier, A bistória cultural, p.51.

${ }^{49}$ Não no sentido howardiano (strictu sensu) ou no da tradição cidade-jardim (lato sensu) que se formou a partir dos esforços para concretizar as propostas originais na Inglaterra e alhures no início do século XX; contudo, falava-se em cidade jardim (para enfatizar o verde, a presença dos elementos naturais ordenados como fato da civilização e do progresso) no XIX, como se usou para, e.g., a cidade de Chicago reconstruída pós-incêndio de 1871 (a propósito, uma provável inspiração para Howard, cf. P. Hall, Cidades do amanhã, 1995, p.104-06).

${ }^{50}$ Cf. George Dantas et alli, A difusão do termo "cidade-jardim”, in Surge et Ambula, 2006, p. 155-168; para uma discussão ainda mais abrangente sobre o tema no Brasil, cf. Carlos de Andrade, Barry Parker, 1998.
} 
Depois de materializado, o texto escapa ao autor. ${ }^{51} \mathrm{~A}$ insistência em analisar os processos de apropriação e circulação de idéias, textos e modelos pelo viés da comparação ao original (o que leva, invariavelmente, ao tema do desvirtuamento) é, no mínimo, problemático - pelo pressuposto que desconsidera (como incapaz ou qualquer outro adjetivo restritivo) o ambiente cultural de recepção que "desvirtuaria" o original. No limite, essa insistência idealiza e autonomiza o próprio texto original, desconsiderando as condições culturais e materiais de sua "gestação".

Se voltarmos ao exemplo da circulação da noção de cidade-jardim, seria ilustrativo um exercício (apenas retórico) do uso de tal abordagem na análise dos esforços e embates para institucionalizar a proposta de cidade-jardim na própria Inglaterra. Como se discutiriam então os empreendimentos para Letchworth e Welwyn, os desenhos de Unwin e Parker para Hampstead ou mesmo a constituição da Garden City Association e os seus esforços para manter a perspectiva de construção de redes de cidades - ao invés de subúrbios-jardins - como alternativa para a reconstrução do primeiro pós-guerra? O próprio Howard e epígonos, como Frederic J. Osborn, estariam desvirtuando o "texto sagrado" ao buscar adequar as propostas de 1898 para torná-las possíveis e disputar espaço (e verbas estatais, obviamente) em meio a outros projetos? ? $^{52}$

Reconhecer as maneiras de circulação e apropriação não significa, assim, limitar-se ao possível ou aceitar os fatos como inexorabilidade histórica - esse seria uma outra armadilha determinista que desemboca, invariavelmente, no conformismo diante dos processos sociais. Não, ao contrário, tal reconhecimento implica mapear e analisar as lutas, os embates, os jogos de interesse, as forças, os símbolos e os

\footnotetext{
51 Utiliza-se aqui a palavra "texto" mas sem a intenção de restringi-la aos documentos impressos. O texto pode ser, em sentido lato, um modelo, um plano, um projeto, um monumento, um conjunto iconográfico, etc., enfim, um elemento que sirva de referência, sintetize e expresse idéias, sentimentos, etc. Ao mesmo tempo, essa extensão da noção de "texto", embora reconheça, não se apóia na antropologia cultural de C. Geertz, i.e., não procura tratar tudo (comportamentos não-escritos, festas, folguedos, crenças, etc., os elementos da história cultural) a partir da "grade da textualização" (Elias Saliba, Perspectivas para uma história cultural, Diálogos, 1997, p.14). Assim, não se pretende incorrer na textualização semiótica do mundo que nos rodeia, como adverte de maneira divertida R. Darton: “ (...) tentem se comportar como se todo comportamento fosse um texto, e [como se] todos os textos pudessem ser desconstruídos: logo vocês se verão presos num labirinto de espelhos, perdidos num reino semiótico encantado, tomados por tremedeiras epistemológicas" (cf. Introdução, in $O$ beijo de Lamourette, 1990, p.18).

52 Cf. P. Hall, cidades do amanhã, 1995, cap. 4; observe-se que esse rico e instigante capítulo do livro de Peter Hall é marcado pela condenação do que considera apostasias em relação ao texto original de Howard.
} 
projetos (de cidade, de sociedade, de mundo) em disputa, a construção (ou a destruição) de possibilidades. Como já afirmou Beatriz Sarlo, interessa não apenas afirmar que um fato ocorreu, mas, sim, entender como pôde ocorrer. ${ }^{53}$

Isso implica reconhecer também que há falseamentos e deformações, deliberadas ou não, conscientes ou não, em relação a textos originais. Há inclusive o esforço do autor em tentar controlar e manter a ortodoxia do seu texto. O glossário que F. J. Osborn propõe em 1949, na $3^{\text {a }}$ edição inglesa do livro de Howard, é ilustrativo desse embate. A terminologia compulsada no prefácio revela a preocupação em distinguir, ao menos dentro da literatura sobre planejamento urbano, o ideário original das várias propostas e tendências que se desenvolveram a partir de então. ${ }^{54}$

Assim, acompanhar esses movimentos, jogos e disputas resulta mais produtivo (para a prática historiográfica) do que a condenação a priori (pelo afastamento do "metro" original) ou do que o exercício estéril de lamentar a não realização conforme esse mesmo metro; ou, mais ainda, de especular como teria sido se a proposta original fosse implementada tal qual, aqui ou alhures. Diante de tal postura, teríamos que argüir, diga-se de passagem, onde, quando e como algum plano urbanístico foi realizado integralmente.

Natal teria se tornado uma cidade melhor se o Plano Geral de Sistematização tivesse sido implementado integralmente (ou em grande parte)? Ou o Rio de Janeiro com o Plano Agache? E São Paulo, com o Plano de Avenidas? Difícil (e, talvez, inútil) responder. Há mais problemas na formulação desse tipo de pergunta para além do (frequentemente lembrado) anacronismo do uso da conjunção condicional "se" na disciplina historiográfica.

Afinal, assume-se que o plano (o projeto de intervenção urbana) seria portador de uma virtude parti pris. Assim, autonomiza-se o plano como um objeto que pairasse acima do tecido social e cultural. Há aí, de fato, um lamento de fundo que se remete às pretensões totalizantes do "projeto" ilustrado - no qual se nutriria a

\footnotetext{
53 A crítica argentina, nessa passagem, discutia o holocausto a partir do filme Shoah, do diretor Claude Lanzmann, que lhe suscitava tais questões fundamentais, i.e., não apenas o lamento e o pesar pelo ocorrido, mas a reflexão sobre os processos que o tornaram possível, cf. B. Sarlo, A história contra o esquecimento, in Paisagens imaginárias, 2005, p. 38, 42.

${ }^{54}$ Frederic J. Osborn, Preface, in E. Howard, Garden cities of To-morrow, 1949, p.26.
} 
cultura técnica moderna e, consequentemente, o campo disciplinar da arquitetura e do urbanismo. Lamento que, vez ou outra, se insinua nos trabalhos de história urbana e urbanística, dominados predominantemente ainda, no Brasil, por profissionais de formação de base em Arquitetura e Urbanismo. ${ }^{55}$

O outro lado dessa moeda é considerar o plano apenas como uma peça do jogo político em busca de hegemonia, um engodo para mascarar ou atender interesses de (setores das) classes dominantes, enfim, como ideologia em seu sentido mais determinista.

\section{Ideologia e representações}

Investigar as representações pressupõe, como discute Chartier, tomá-las dentro do campo de disputa e concorrências em que se inserem e ajudam a estruturar, "cujos desafios se enunciam em termos de poder e de dominação". Destarte, as lutas de e pelas representações seriam tão importantes quanto as lutas econômicas e políticas para o ofício historiográfico porque aquelas - as representações - podem revelar as estratégias dos grupos e ou classes sociais para elaborar e (tentar) impor visões e valores de mundo. Indo além, enfatiza-se que aí, nas representações, pode-se identificar "pontos de confrontamento" decisivos conquanto menos ou mesmo não materiais. ${ }^{56}$

Apoiando-se nos estudos de Pierre Bourdieu e recuperando textos inaugurais de Emile Durkheim e Marcel Mauss, ${ }^{57}$ o historiador francês afirmaria a necessidade de deitar por terra de vez os "falsos debates" entre a objetividade das estruturas e a subjetividade das representações.

Há, de fato, aí uma oposição à noção de ideologia tal qual tomada da matriz marxista do materialismo histórico. No sentido mais restrito da palavra em Marx, a

55 Como se percebe claramente na composição de participantes e conferencistas dos Seminários de História da Cidade e do Urbanismo, desde a sua primeira edição, em 1990, em Salvador; a asserção aqui é claramente especulativa, mas pode encontrar fundamento, como já apontaram os professores Marco Aurélio Gomes e Eloísa Pinheiro, na constatação de que as pesquisas em história urbana e do urbanismo no Brasil caracterizaram-se, desde o final dos anos 1970, pela perspectiva de repensar a cidade (e a possibilidade do projeto) pelas dimensões da cultura e da história (Cf. Os arquitetos, a cidade e o fascínio pela história, in $A$ cidade como bistória, 2004, p.09-18).

${ }^{56}$ R. Chartier, A bistória cultural, 1988, p.17-18.

${ }^{57}$ A referência é ao texto "De quelques formes primitives de classification. Contribuition à l'étude des représentations collectives”, publicado em Année sociologique, em 1903. 
ideologia - conceito que englobaria as representações - aparece marcada e diferenciada pelos cortes sociais, expressando os interesses de cada classe e operando principalmente pelo ilusório e pelo irreal. Numa perspectiva teleológica, a emergência da classe operária como força histórica levaria ao desvelamento de todo e qualquer aparato ideológico (mitos, representações, etc.) porque não haveria a necessidade num futuro sem classes - de criar ilusões sobre si mesma; sem divisões sociais, não haveria a necessidade da ideologia para embotar os conflitos e suas causas. Baczko ressalta, contudo, que na leitura de situações históricas coetâneas, como em o "18 Brumário", Marx empreenderia um uso mais complexo da noção de ideologia, considerando a construção de imagens, as disputas do imaginário, etc., como parte das práticas sociais. ${ }^{58}$

De fato, deve-se reconhecer que, a despeito da crítica acertada à prática historiográfica da chamada vulgata marxista ou da leitura ortodoxa de autores de inspiração marxista, o materialismo histórico apontava para uma abordagem mais complexa do chamado fenômeno histórico-social do que o mero determinismo economicista denunciado a posteriori.

Outro traço característico oriundo dessas formulações encontra-se na leitura especular entre, para se utilizar os termos marxistas, estrutura e superestrutura; essa refletiria, não necessariamente de maneira sincrônica, os elementos fundamentais daquela. Não à toa, ao abrir o célebre ensaio sobre "a obra de arte na era de sua reprodutibilidade técnica", Walter Benjamim partiria da análise de Marx sobre o modo de produção capitalista para afirmar que "a superestrutura se modifica mais lentamente que a base econômica"; daí porque aquelas mudanças percebidas por Marx nas condições de produção da primeira metade do século XIX tivessem levado mais de cinqüenta anos para "refletir-se" na cultura.

Obviamente, não se pretende reduzir a complexa e por vezes contraditória prática historiográfica de Benjamim a essa relação especular e determinista entre a

\footnotetext{
${ }^{58}$ B. Baczko, Imaginación social, imaginarios sociales, in Los imaginários sociales, 1991, p.20-21; lembrese que no prefácio a "A Ideologia Alemã”, Marx conclamaria seus pares a se libertarem das quimeras, idéias, dogmas e seres imaginários que moldariam as "false conceptions about themselves, about what they are and what they ought to be", cf. K. Marx, Preface, in The German Ideology, 1968, p.03. De qualquer maneira, reconheça-se a distância entre o pensamento complexo de Marx e a redução aqui operada, em prol de um determinado corte narrativo - sobre um uso preciso da noção de ideologia.

59 W. Benjamim, Magia e técnica, arte e politica, 1994 [1935-36], p. 165.
} 
base econômica e as manifestações culturais, artísticas, sociais, etc. Afinal, o próprio Benjamim, nas suas teses "sobre o conceito de história", lembraria que as "coisas refinadas e espirituais" não são meros despojos deixados ao vencedor da luta de classes, da luta pelas "coisas brutas e materiais" - luta que deveria interessar a qualquer historiador educado em Marx; ao contrário, as coisas refinadas, sob a forma da coragem, da astúcia, da confiança, etc., põem em xeque sempre, ontem e hoje, a vitória dos dominadores. Uma porta de entrada, portanto, para uma história que, opondo-se à perspectiva teleológica, volta-se para o sofrimento do passado e não para as promessas do futuro. ${ }^{60}$ De resto, o interesse de Benjamim estava voltado, nesse aspecto, para a expressão da economia na cultura e não para a origem econômica da cultura. ${ }^{61}$

Essa pequena digressão sobre a questão da ideologia é praticamente inescapável, tendo em vista a influência na prática historiográfica e no questionamento do próprio lugar do historiador. Em relação aos usos da noção de ideologia na construção da narrativa historiográfica, há dois trabalhos (importantes, diga-se) que mostram os limites da sua aplicação (como o que vela o real) nos escritos de história do urbanismo. ${ }^{62}$

Nesse sentido, faça-se ainda outra observação: nas últimas décadas, os trabalhos da filósofa Marilena Chauí parecem ter sido decisivos para disseminar essa leitura do conceito de ideologia no Brasil, amplamente fundamentado nas teses de Marx (em especial n’A “Ideologia alemã”). ${ }^{3}$

${ }^{60}$ Ibidem [1940], tese 4, p. 223-24.

${ }^{61}$ B. Sarlo, Esquecer Benjamim, in Paisagens imaginárias, 2005, p.102 - esse ensaio da crítica argentina é particularmente importante para entender a platitude de muitas apropriações de temas e categorias de Benjamim na onda dos estudos culturais das últimas décadas. Adrián Gorelik recupera essa discussão, apontando um certo mal-estar (e mesmo esgotamento) dos estudos sobre os imaginários urbanos, cf. Transformaciones urbanas e estudios culturales (para um recorrido por los lugares comunes de los estúdios culturales urbanos), in Miradas sobre Buenos Aires, 2004, p.259-279. Sérgio Paulo Rouanet estabeleceu discussão próxima: embora reconheça a existência de muitos e válidos Benjamims, condenaria ainda assim a "leitura irracionalista" que se daria no Brasil, "segundo a qual ele [Benjamim] defenderia o primado da vida contra a razão, da experiência imediata contra a abstração, da atualidade histórica contra a história" (cf. Benjamim, falso irracionalista, in As razõos do iluminismo, 1987, p.111).

62 V. Rezende, Planejamento urbano e ideologia, 1982, e F. Villaça, Uma contribuição para a história do planejamento urbano no Brasil, In C. Deák e S. R. Schiffer (orgs.), O processo de urbanização no Brasil, 1999.

${ }^{63}$ M. Chauí, O que é ideologia, 1983, p.21; apesar da importância de outros livros e artigos, citamos aqui apenas esse título da coleção Primeiro Passos da editora Brasiliense, lançado em 1980 e que se encontrava em sua $12^{a}$ edição já em 1983. Conquanto reforce o conceito de ideologia como instrumento de dominação de classe que opera no registro da ilusão, Chaú estabelece de forma clara a 
Isso posto, pode-se fazer alguns breves comentários sobre os textos dos professores Vera Rezende e Flávio Villaça. A escolha que se faz aqui de ambos tem algo de arbitrário, embora se reconheça que, de certa maneira, podem ser tomados como marcos (dentre vários outros) para entender algumas características da conformação do campo disciplinar da história da cidade e do urbanismo no Brasil.

Afinal, o livro da professora Rezende é anterior aos esforços mais consistentes que seriam feitos a partir do final dos anos 1980. Embora não se nomeie claramente como pertencente à história urbana ou urbanística, a autora busca problematizar as relações entre planejamento urbano e ideologia na história dos planos urbanos elaborados para a cidade do Rio de Janeiro ao longo do século XX (Agache, Doxiadis, PUB Rio e PIT Metrô). Para cada momento, a autora descreve e discute o contexto histórico-social específico, do país e da cidade, os esforços de gestão do plano, o plano em si (com seu modelo de cidade implícito, objetivos, estrutura metodológica e as proposições específicas para as questões relacionadas à estrutura urbana, habitação, saneamento e sistema viário), além da implementação parcial de todos.

A questão da ideologia perpassa a construção do texto, como fora anunciado na própria introdução. O corte crítico é, expressa e acertadamente, de viés marxista, a partir da leitura de, principalmente, Castells, Althusser e Chauí. ${ }^{64}$ Daí a leitura do "sistema ideológico" como um dos "elementos fundamentais de uma estrutura social" - e que, no caso do modo de produção capitalista, estaria, junto com o sistema jurídico-político, em relação de subordinação ao sistema econômico. ${ }^{65}$

Em meio à importante leitura dos dados primários levantados dentro das categorias propostas, esse quadro teórico leva a alguns problemas na análise, a dizer, no aspecto que nos interessa destacar, a compreensão do "sistema ideológico" como

\footnotetext{
que se refere essa ilusão. Deve ser entendida como "abstração e inversão" e não como ficção, invenção arbitrária ou falsidade. Abstração por aceitar a realidade tão-somente como dado sensorial, sem questionar como é concretamente produzida. Inversão por tomar os efeitos pelas causas, as conseqüências pelas premissas. Assim, enfatiza que "uma ideologia sempre possui uma base real, só que essa base está de ponta cabeça, é a aparência social" (i.e., "o modo como o processo social aparece para a consciência direta dos homens"). Enfim, a ideologia não seria uma esfera autônoma (embora saibamos que assim se pretenda, muitas vezes, como se fossem pura criação do espírito a pairar sobre as realidades históricas, geográficas, sociais), mas uma práxis social.

${ }^{64}$ V. Rezende, op. cit., "introdução” e "quadro teórico", p.15-32 passim.

${ }^{65}$ Ibidem, p.24.
} 
um bloco quase homogêneo, sem maiores fissuras, conflitos, marchas e contramarchas. Conquanto reconheça a reprodução desse sistema como práxis social cujos agentes são os indivíduos (em relação, diga-se, com grupos de indivíduos, associações classistas, profissionais, religiosas ou intelectuais, etc.), o livro leva à compreensão do Plano Agache, e.g., como uma acomodação entre os interesses de uma oligarquia agrária em declínio e uma burguesia industrial em franca ascensão. ${ }^{66}$ Amarrado ao interesse em desvelar as causas estruturais dos movimentos que levariam à proposição do plano, o texto não consegue dar conta, assim, da complexidade e riqueza que marcariam esses mesmo movimentos. Não contempla, portanto, a quantidade de diálogos cruzados (interesses profissionais, visões de cidade e sociedade diversos, formações intelectuais de diferentes tradições, etc.) que convergem para e em torno do plano e que podem ser ainda mais reveladores dos interesses em jogo.

A contratação de Agache e equipe e o trabalho realizado entre 1927 e 1930 levou forçosamente à elaboração e a debate sobre novas questões que foram postas em debate e que teriam impacto, ainda que não direto, sobre a formulação de políticas públicas para a cidade do Rio de Janeiro nos anos seguintes, como o demonstram vários trabalhos posteriores. ${ }^{67}$ Questões que não nasceram tão-somente da acomodação das forças político-econômicas, mas, sim, que encontram aí possibilidades de prosperar, de transformar e transformar-se nos embates. Da mesma maneira, as novas questões - oriundas das reflexões do campo disciplinar do urbanismo então em formação desde o início do século XX - não se resumem à transferência de discussões formuladas alhures. Elas só fazem e ganham sentido se há uma, para usarmos uma expressão de Backzo, "comunidade de sentidos" que pode se lhes apropriar e fazer circular as palavras, os conceitos, as noções, ainda que vagas, que as sustentam.

Não se pretende aqui cobrar respostas ou análises para questões que não estavam colocadas na época do livro citado. Inclusive, os objetivos da pesquisa revelam muito das preocupações dessa época - retomada das lutas pela reforma

\footnotetext{
${ }^{66}$ Ibidem, p.27, 37-40.

${ }^{67}$ Dentre os quais, cito o livro da pesquisadora Denise C. Stuckenbruck, O Rio de janeiro em questão, 1996, e um artigo da própria Vera Rezende, Evolução da produção urbanística na cidade do Rio de Janeiro, 1900-1950-1992, in Urbanismo no Brasil - 1895-1965, 1999.
} 
urbana como parte do processo de redemocratização do país, como já era possível vislumbrar no início dos anos 1980, o que implicava desvelar a pretensa neutralidade do discurso técnico na proposição de soluções espaciais para cidades marcadas por uma crescente pobreza urbana, expansão periférica, crescimento demográfico, etc. Interessa apontar que essa estrutura metodológica e conceitual mostrar-se-ia insuficiente ou limitada para dar conta das tramas e contextos em que os planos urbanísticos adquiriam e ainda adquirem significância.

Problema ou limitação similar marca o texto do professor Villaça. Contudo, aqui, as limitações se exacerbam pelo próprio lugar que ocupa. Afinal, publicado no final da década de 1990, pode ser tomado como texto de referência que busca sistematizar a discussão histórica em prol de uma compreensão atual do fenômeno de produção e reprodução do planejamento urbano no Brasil, como ressalta desde o início. ${ }^{68}$ Diretamente ou não, dialoga com uma produção que se avolumava desde o início dessa mesma década.

Ainda assim, e apesar do claro cuidado metodológico em delimitar o objeto a analisar, permanecem problemas na definição do que seria (e do que é) o planejamento urbano e, mais grave, defende-se aqui, na sub-avaliação do urbanismo sanitarista como um dos "tipos constitutivos do planejamento urbano lato sensu" (os outros seriam o planejamento urbano strictu sensu, o zoneamento, os planos de cidades novas e os planos de infra-estrutura urbana). ${ }^{69}$

A tese central de Villaça é que só se entende a (re)produção do planejamento urbano no Brasil nos últimos 50 anos se se a considera como ideologia, cujo paradoxo se encontraria na retomada dos planos diretores no final dos anos 1980, com a nova Constituição Federal. Afinal, nessa chave de leitura, as lutas sociais pelas reformas urbanas teriam desaguado na exigência de uma peça que, antes, era quase que somente um artifício ideológico travestido de neutralidade e racionalidade. Assim, as várias mudanças de nome, de metodologia e de conteúdo ao longo da história teriam sido "estratagemas dos quais as classes dominantes lançaram mão para renovar a ideologia dominante (...)". ${ }^{70}$

\footnotetext{
${ }^{68}$ Villaça, op. cit., p.171

${ }^{69}$ Ibidem, p.175, 179.

${ }^{70}$ Ibidem, p.182.
} 
Partindo das noções de ideologia, discutida por Chauí, e de hegemonia, tal qual em Gramsci, lerá a história do planejamento urbano no Brasil ao longo do século XX como um processo contínuo de descolamento da realidade, cujo paroxismo seriam os grandes planos dos anos 1960 e 1970. Processo também de perda de hegemonia em torno dos planos: se os projetos de Pereira Passos para a área central do Rio de Janeiro em 1906, que considera como o auge dos "planos de melhoramentos", foram realizados em sua quase totalidade, o mesmo não se poderia dizer dos outros que, por todo o Brasil, foram propostos a posteriori. ${ }^{71}$

Mais uma vez, há aí o problema de tomar o sistema ideológico como um bloco homogêneo, produzido sem arestas por um determinado grupo social. Leitura que, observe-se, não contempla as possibilidades analíticas expostas na própria discussão dos pressupostos teóricos realizada pelo autor. ${ }^{72}$ Nesse jogo de veladesvela, perde-se a referência ao papel ativo de profissionais, intelectuais e instituições envolvidas, assim como das maneiras de circulação de idéias, temas, polêmicas nos quais os planos se inseriram e se inserem.

Assim, considera-se importante marcar que a superação dessas limitações e a abertura de possibilidades de trabalhar com novas fontes para a construção de uma história urbana e urbanística mais complexa e abrangente deriva tanto da premência colocada pelas novas questões historiográficas quanto pela existência de uma história política e econômica mais consolidada.

O conjunto de artigos compulsados pela coletânea organizada por Luiz César Ribeiro e Robert Pechman, anterior ao texto de Villaça, é exemplar dessa assertiva: ao tomar a produção oriunda do campo do urbanismo como representação, conseguiram enfrentar com mais êxito os dilemas (metodológicos e conceituais) de tratar essa trama específica em relação, inescapável, com as demais tramas do tecido social, cultural, econômico. ${ }^{73}$ As relações produtivas entre o discurso técnico do urbanismo e as formulações do chamado pensamento social brasileiro seria uma

\footnotetext{
71 Ibidem, p.192-198, 222.

72 Ainda que de forma breve, estabelece com precisão os conceitos de ideologia e hegemonia, cf. Ibidem, p.183-84, nota 2, e p.226.

${ }^{73}$ Cf. Luiz Ribeiro e Robert Pechman, Cidade, povo e nação, 1996.
} 
entrada profícua para a historiografia no Brasil, como o demonstram vários trabalhos posteriores. $^{74}$

Para encerrar essa parte do texto, considera-se importante estabelecer algumas considerações sobre a historiografia da área no Brasil. Depois de diversos estudos desenvolvidos entre os anos 1930 e 1960 - como os de Sérgio Buarque de Holanda, Gilberto Freyre, Aroldo Azevedo, Pierre Deffontaines, Robert Smith e Nestor Goulart Reis - que se tornaram clássicos e que versavam principalmente sobre o período colonial, a problematização da formação histórica das cidades é retomada principalmente pelas pesquisas e discussões em torno do primeiro ciclo de reformas urbanas. Abrangido temporalmente, grosso modo, entre 1890 e 1920, o processo de transformações que marca esse ciclo foi chamado, significativamente, de "desconstrução da cidade colonial". ${ }^{75}$ É significativo que essa retomada tenha sido marcada também, como já se discutiu, pelo esforço de

superação do isolamento nos estudos de história urbana, ou do seu enquadramento na chave dos indefectíveis "antecedentes", [o que] exprime por certo o esgotamento ao longo dos anos 1980 de um vínculo histórico, ao menos na tradição do pensamento e da historiografia no Brasil, entre a investigação do passado e as exigências do presente, no caso entre a pesquisa urbana e as tarefas do planejamento. ${ }^{76}$

Isto é, reivindicou autonomia e pressupôs a superação de uma dimensão (apenas) operativa da história urbana ou da história da cidade e do urbanismo. ${ }^{77}$ Escapou-se dos riscos da instrumentalização do passado pelas injunções do presente

\footnotetext{
${ }^{74}$ Dentre os quais, destacamos a tese de José Lira, Mocambo e Cidade, 1996, e o livro de Candido Campos, Rumos da cidade, 2002, em especial a parte sobre as discussões entre urbanismo e antiurbanismo por diversos intelectuais brasileiros.

75 Eloísa Pinheiro e Marco Aurélio Gomes, Retraçando percursos: o papel dos Seminários de História da Cidade e do Urbanismo na constituição de um campo de estudos, in A cidade como História, 2004, p.20.

${ }^{76}$ Virgínia Pontual e José Lira, Cidade, planejamento e gestão urbana: história das idéias, das práticas e das representações, in Anais Eletrônicos do X ENANPUR, 2003, p.01.

77 Não iremos discutir aqui a problemática relacionada à própria nomeação dessa área do conhecimento no Brasil, mas apenas registrar que algumas reflexões sobre o tema foram propostas desde o início, cf. R. Rolnik, História Urbana: História na cidade?, In Cidade e História, 1992, p. 27-29; N. G. Reis, Sobre história da urbanização - história urbana, Espaço e Debates, 1991, p.15-18; mais recentemente, abordando principalmente a literatura em inglês, cf. L. O. Silva, Cidade e História: um olhar epistemológico, in A cidade como História, 2004, p.151-173; há uma importante contribuição, embora pouca conhecida na produção brasileira, proveniente das discussões historiográficas na Espanha, cf. e.g. A. A. Mora, Problemas de investigación en "História urbanística", História Urbana, 1992, p.83-102.
} 
para incorrer em novos riscos - metodológicos, teóricos, conceituais. Estes, pelo menos, constitutivos da própria disciplina, a dizer, e.g., a necessidade de problematização das fontes, o reconhecimento das representações como construções da realidade - e não como a realidade em si -, a consideração dos diferentes tempos históricos da modernização e das suas conseqüências para além das dimensões técnica, material, burocrática, etc. Riscos que marcaram e foram enfrentados, em maior ou menor grau, (teoricamente) consciente ou não, pela produção recente.

Arriscou-se dizer ademais que essa retomada foi marcada por um desencanto com as possibilidades de transformação do urbano (enredados em projetos de transformação social), com a crise dos próprios paradigmas modernos, dos saberes sobre as cidades. Haveria então, no voltar-se ao passado, um certo conformismo ante tal quadro de crise. ${ }^{78} \mathrm{O}$ que poderia ter gerado estudos de apelo nostálgico. Não parece ter sido este o caso e, a despeito de certo entusiasmo na leitura da ação épica dos urbanistas do início do século XX, e.g., a visada crítica dos estudos de história da cidade e do urbanismo têm cada vez mais incorporado rigor de método e análise.

Enfim, como bem discute Elias Saliba, esse retorno ao cultural revela o "cansaço" com uma história baseada em estruturas, hierarquias, sistemas, etc., i.e., com uma história como processo mas sem sujeito. "Compreender como os homens do passado se compreendiam" tornou-se uma nova missão. Ao mesmo tempo, essa mudança traz consigo novos problemas: o passado passou a ser visto como um “feixe de práticas discursivas", uma sucessão, por vezes infindável, de versões sobrepostas, fragmentando-se num "difuso território da indeterminação". 79

\section{Representações em disputa}

Postas tais considerações, é importante recuperar as discussões estabelecidas por Chartier como uma porta de entrada privilegiada para entender o valor heurístico das representações no campo de uma possível histórica cultural urbana e do

\footnotetext{
78 Cf. A. Fernandes, M. A. Gomes, A pesquisa recente em história urbana no Brasil: percursos e questões, In N. Padilha (org.), Cidade e Urbanismo: história, teorias e práticas, p.13-28, 1998; V. Pontual e J. Lira, Cidade, planejamento e gestão urbana: história das idéias, das práticas e das representações, In Anais Eletrônicos do X ENANPUR, 2003; C. Topalov, Os saberes sobre a cidade: tempos de crise?, Espaço \& Debates, p.28-37, 1991.

${ }^{79}$ Elias T. Saliba, Perspectivas para uma historiografia cultural, Diálogos, 1997, p.13.
} 
urbanismo. Contudo, não se pretende estabelecer aqui uma longa descrição do estado da arte sobre o tema ou sobre a própria obra do historiador francês. Importa, sim, encontrar elementos para empreender uma leitura que problematize algumas das questões, dilemas e potenciais atuais da historiografia - em especial, para os profissionais não oriundos de formação de base nas disciplinas da História.

O professor Flamarion Cardoso aponta quatro elementos centrais que permitem entender as linhas do trabalho de Chartier. ${ }^{80}$ Em primeiro lugar, a crítica à noção das mentalidades, como discutido no início destas notas, e, em segundo, a crítica ao enfoque geertiziano, que seria dominante na antropologia.

Em ambas críticas, a insatisfação com a leitura e análise que homogeneizaria a maneira de percepção dos sujeitos e a sua relação com os produtos culturais, com as estruturas sociais e econômicas. Contra as mentalidades, por tomar os objetos analisados como válidos por si e não construídos no e pelo discurso. Há, como se percebe, uma aproximação dessa crítica aos trabalhos que vinham sendo desenvolvidos por Carlo Ginzburg e Michel Foucault, embora, em relação a esse, Chartier mantenha severas críticas à noção de apropriação. Contra o enfoque de Clifford Geertz, que consideraria reducionista, por ver as formas simbólicas organizadas em um sistema como se fossem compartilhadas igualmente pelos membros de um grupo, deixando de perceber as diversas maneiras de apropriação e de conflitos.

Nesse sentido, também se aproximaria da crítica à noção de zeitgeist, crítica formulada, dentre outros, pelo historiador da arte E. H. Gombrich. Reconhecer os mil fios que unem uma determinada criação à cultura de uma época não implica, defende Gombrich - contra o princípio organizador hegeliano -, "que todos os aspectos de uma cultura podem ser reconduzidos a uma causa nodal, de que são manifestações". ${ }^{81}$

\footnotetext{
${ }^{80}$ Ciro F. Cardoso, Introdução: uma opinião sobre as representações sociais, in Representacões, 2000, p.12-17.

${ }^{81}$ E. H. Gombrich, Para uma história cultural, 1994 [1969], p. 63; não é possível aprofundar essa leitura aqui, restando-nos apenas a indicação da leitura dessa palestra, assim como de Arte e Ilusão, 1986 [1959]. Essa perspectiva de crítica, formulada como o problema da "circularidade da interpretação", seria retomada com muita lucidez por outro admirador do Warburg Institute, Carlo Ginzburg, cf. De A. Warburg a E. H. Gombrich: notas sobre um problema de método, in Mitos, Emblemas, Sinais, 1989 [1966], p.63-64. Chartier também discutiria a necessidade de "renunciar a Hegel", cf. O passado composto: relações entre filosofia e história, in A História cultural, 1988, p.73-77.
} 
A aproximação e a incorporação de alguns conceitos centrais da obra de Pierre Bourdier seria o terceiro elemento apontado: a busca de uma reinterpretação do marxismo à luz de uma análise que incorporasse tanto os sentidos subjetivos quanto os objetivos das ações, que permitiria aos historiadores reconhecerem a liberdade de escolha dos indivíduos - dentro, claro, dos limites socialmente estabelecidos. O conceito de habitus seria então fundamental. Por fim, a filiação a uma premissa básica dos Annales, a dizer, a compreensão da história como uma ciência social.

Observe-se que, em artigo do final dos anos 1980, Chartier buscara situar com precisão o lugar de suas pesquisas e preocupações no quadro de mudanças disciplinares e dos fundamentos das ciências sociais. Um quadro que se poderia configurar como de crise - marcada por diversas indecisões em meio ao refluxo do marxismo e do estruturalismo. ${ }^{82}$

Para Chartier, a prática historiográfica teria mudado a partir de três deslocamentos, relacionados diretamente aos princípios de inteligibilidade que permitiriam inscrever a história como uma ciência social. Ademais, nega que essas mudanças derivassem de uma mudança de paradigma, como propugnado por alguns entusiastas do pós-modernismo. Mudanças que vieram: primeiro, da renúncia ao projeto de uma história global; rompia-se com o modelo braudeliano e, consequentemente, com as partições rígidas e hierárquicas das práticas sociais. Segundo, da renúncia à definição territorial dos objetos de pesquisa; passou-se da "cartografia das particularidades" tão-somente para uma "pesquisa das regularidades", i.e., a busca de leis gerais ao invés das singularidades.

Emerge aí uma questão metodológica cara às reflexões sobre a área de história urbana e do urbanismo no Brasil, marcada, necessariamente, por um acúmulo de estudos monográficos - em razão, dentre vários fatores, pela dimensão continental de um país com tantos tempos históricos, espaços geográficos e processos de modernização diversos. É possível uma análise que abarque o fenômeno histórico-social em características "nacionais"? como bem pontuou

82 R. Chartier, O mundo como representação, Estudos Avançados, 1991. 
Chartier: "como pensar o acesso ao geral a partir do momento em que não é mais tido como a soma cumulativa das constatações particulares?" ${ }^{83}$

As possibilidades de resposta são diversas, indo desde a correlação estatística até a discussão do paradoxo do chamado "excepcional normal", que procura o mais comum no que é menos corriqueiro. Nesse vertente, em especial, as considerações metodológicas da micro-história são fundamentais, como o demonstra cabalmente um clássico do gênero: o livro de Ginzburg sobre Menocchio, o moleiro friulano perseguido pela Inquisição no final do século XVI.

Mas, afinal, perguntar-se-ia Ginzburg, qual a relevância do estudo de um indivíduo para a compreensão de uma época? Antes de mais nada, não se pode descartar uma documentação singular e excepcional. Segundo, é importante, se possível, estender o "conceito histórico de indivíduo" às classes mais populares, mesmo correndo o risco de cair no anedotário - risco evitável, diga-se. Um indivíduo, mesmo medíocre, pode ser representativo, como um "microcosmo", de um estrato social de um determinado período. Contudo, não é esse o caso de Menocchio. Ele não era um camponês "típico" (ou médio, aquele estatisticamente mais freqüente) ${ }^{84}$

Contudo, sua singularidade tem limites. Limites da cultura do próprio tempo, da classe a que está vinculado. "Assim como a língua, a cultura oferece ao indivíduo um horizonte de possibilidades latentes". Menocchio configura assim um caso-limite, pelo que revela em negativo (ajudar a precisar o que numa época é estatisticamente mais freqüente) e em positivo (circunscreve as possibilidades latentes de algo, no caso, a cultura popular, acessível por fontes indiretas, fragmentárias, deformadas). ${ }^{85}$

A atenção ao individual não desmerece, ressalta, a importância dos estudos quantitativos, seriados. Mas é necessário estabelecer uma série de críticas. A busca do elemento médio, e.g., nem sempre aponta para o essencial, para os textos que tiveram grande impacto, e pode obscurecer a questão de que há uma cultura popular que conforma as práticas de leitura. "Mas como eram lidos pelo público de então? Em que medida a cultura predominantemente oral daqueles leitores [da época de

\footnotetext{
83 Ibidem, p.177.

${ }^{84}$ C. Ginzburg, O queijo e os vermes, 2005, p.24.

${ }^{85}$ Ibidem, p.25-26.
} 
Menocchio] interferia na fruição do texto, modificando-o, remodelando-o, chegando mesmo a alterar sua natureza?". ${ }^{86}$

Essa questão levantada e enfrentada por Ginzburg é crucial para Chartier também. A problematização das diferenças entre cultura popular e erudita, entre a lógica de produção textual e a lógica da prática das ações, entre criação e consumo, entre realidade e representação, enfim, apontam os caminhos para uma reflexão que renunciaria ao que chamou de "primado tirânico do social".

Criticando os pressupostos estruturalistas, afirmaria que "a realidade é construída culturalmente". No lugar de uma história social da cultural, uma história cultural do social. Chartier já foi muito criticado por essa postura, que teria levado, como já apontaram Lynn Hunt e Ronaldo Vainfas, à “tirania do cultural”. Peter Burke lembraria, a propósito, que virar-se contra o determinismo material não poderia excluir os fatores materiais da problematização da história, afinal os homens reagem, adaptam-se, enfrentam, trabalham sobre as questões do meio ambiente físico, os seus recursos a longo prazo, etc. ${ }^{87}$

Certo também que esse "reducionismo culturalista" seria superado. Em On the edge of the cliff, livro de 1997, Chartier faz um balanço de sua produção historiográfica e uma avaliação dos seus diálogos intelectuais. Nessa exposição, reconheceria que não cabem reduções para entender as relações complexas entre o cultural e o social: nem a cultura pode ser vista como uma manifestação dos arranjos sociais, nem tampouco o "social" opera com as mesmas lógicas e regras da cultura e da linguagem..$^{88}$

Assim, em meio às muitas questões que emergem dos estudos de Chartier, destacamos, para concluir este texto, algumas das quais parecem profícuas para instigar reflexões e paralelos aos interesses desta tese.

A problemática do "mundo como representação" evoca questões fundamentais para pensar as maneiras de circulação e apropriação de ideários, modelos, projetos urbanísticos; assim, deve-se considerar como se dá a apropriação pelos leitores de textos (que contém tais figurações). "No ponto de articulação entre

${ }^{86}$ Ibidem, p.26-27.

${ }^{87}$ Ciro Cardoso, Introdução: uma opinião sobre as representações sociais, in op. cit., p.11, 19-20.

88 J. Dewald, Roger Chartier and the fate of cultural history, French Historical Studies, 1998, p.222-23. 
o mundo do texto e o mundo do sujeito coloca-se necessariamente uma teoria da leitura capaz de compreender a apropriação dos discursos, isto é, a maneira como estes afetam o leitor e o conduzem a uma nova norma de compreensão de si próprio e do mundo". ${ }^{89}$

Assim, é possível entender e mapear as relações recíprocas entre imaginação (dimensão da reflexão político-técnica) e imaginário (reflexão cultural) urbanos. Relações essas fundamentais, como bem lembrou Adrián Gorelik, para a tradição intelectual latino-americana do século XX. "La representación de modernidad crea realidad urbana y ella refuerza la representación de un ideal de nación: así podría decirse que funcionó la relación entre ciudad y representación em esta tradición cultural". ${ }^{90}$

Muitos processos de intervenção urbanística na América Latina - entendendo o Brasil como parte dessa realidade cultural e territorial - conformaram não apenas projetos mas também interpretações, representações, que se embebiam no debate existente e traziam novos temas à baila.

Assim, deve-se considerar insatisfatória uma abordagem que considere transparente a relação texto-leitor, como se o primeiro se reduzisse ao conteúdo semântico, e o segundo fosse abstrato e não marcado por variáveis sociais e históricas; ao contrário, o ato de leitura é concreto, um processo de construção de sentido e de interpretação; assim, requer considerar que o leitor é dotado de competências (que dizem respeito as suas posições e disposições) e que os textos dependem dos "dispositivos discursivos e formais". 91

Aqui, também, a noção de apropriação é outra. Nem é a de Foucault (que se interessa pela apropriação como confisco e submissão dos discursos), nem a da hermenêutica. A "apropriação social dos discursos" de Foucault seria restrita às determinações hierárquicas dos jogos de poder. ${ }^{92} \mathrm{~A}$ reformulação da noção aponta para uma "história social das interpretações, remetidas para as suas determinações

\footnotetext{
${ }^{89}$ R. Chartier, A história cultural, 1988, p.24; grifos nossos.

90 A. Gorelik, Imaginários urbanos e imaginación urbana, in Miradas sobre Buenos Aires, 2004, p.262.

${ }^{91}$ Chartier, A bistória cultural, 1988, p.25-26.

92 Idem, O mundo como representação, Estudos Avançados, 1991, p.180.
} 
fundamentais (que são sociais, institucionais, culturais) e inscritas nas práticas específicas que as produzem". ${ }^{93}$

Portanto, Chartier está mais interessado nas "diferenças do uso partilhado", como Bourdieu, e não nas exclusões por confiscação. As práticas contrastantes devem ser compreendidas como concorrências, as suas diferenças pelas estratégias de distinção ou imitação e que os empregos diversos de um mesmo bem inserem-se nas disposições do habitus de cada grupo. ${ }^{94}$

Para Chartier, há diferenças fundamentais entre prática e discurso. Contudo, não precisa os termos: pelos usos, percebe-se a tendência a usar discurso para as esferas de autoridade e poder e prática para o que é inovativo, popular, resistente ao poder. A história deveria então ficar atenta às tensões entre as capacidades inventivas dos indivíduos ou comunidade e os constrangimentos, normas e convenções que limitam o que é possível pensar, expressar, fazer. ${ }^{95}$

Essas considerações - que têm como noções chave a representação, a prática e a apropriação - revelam uma história cultural pensada como "a análise do trabalho de representação"; mais ainda, como "o estudo dos processos com os quais se constrói um sentido", defenderia Chartier. ${ }^{96}$

Para tanto, foi fundamental recuperar a trajetória dos Annales e as discussões fundadoras de Lucien Febvre e Marc Bloch, em especial a relação com a então chamada história intelectual. Antes de mais nada, lembra Chartier, interessava a Febvre (que conclamava a todos interessados na história dos movimentos intelectuais) reencontrar a "originalidade, irredutível a qualquer definição a priori, de cada sistema de pensamento, na sua complexidade e na sua mudança". 97 Como pressuposto, buscava, ademais, ao estudar a relação entre as idéias e a realidade social, não utilizar as categorias de influência ou do determinismo. Febvre estava então se insurgindo contra um marxismo simplificado.

\footnotetext{
93 Idem, A bistória cultural, 1988, p.26.

94 Ibidem, p.124.

${ }^{95}$ J. Dewald, op. cit., p.224.

${ }^{96}$ Chartier, A bistória cultural, 1988, p.27.

${ }^{97}$ L. Febvre, 1909, apud Ibidem, p.33.
} 
Os escritos do Febvre maduro seriam mais críticos em relação a uma história intelectual que chamava de desencarnada, i.e., aquela (feita principalmente pelos historiadores da filosofia) que isolava as idéias ou sistemas do pensamento das condições que permitiram sua (re)produção, separando-os das formas de vida social.

Há uma aproximação desse Febvre maduro, principalmente o do livro Rabelais, de 1942, a trabalhos de E. Panofsky, como Gothic architecture and Scolasticism, de 1951. Ambos procuraram se dotar de meios intelectuais para enfrentar o problema de compreender o zeitgeist. Afastar-se-iam também das noções que dominavam até então: que postulavam que havia uma relação consciente e transparente entre as intenções dos produtores e seus produtos; que a criação intelectual (ou estética) era atributo individual; que explicavam a concordância entre vários produtos e/ou produtores por meio do jogo dos empréstimos e das influências. ${ }^{98}$

Para enfrentar e superar tais noções, ambos proporiam novas categorias: a de habitus (como trabalhada inicialmente por Panofsky) e a de utensilagem mental (Febvre).

A utensilagem ou equipagem mental (outillage mental) vale para a civilização que a forjou, pela época que a utiliza, e não pela eternidade e para toda a humanidade. Assim, desdobra-se que as "categorias do pensamento" não são universais e dependem dos "instrumentos materiais" (as técnicas) e "conceituais" (as ciências). O que define a utensilagem mental é: o estado da língua (léxico e sintaxe), os utensílios e a linguagem científica disponíveis, e o sistema das percepções - esse "suporte sensível do pensamento".99

Ao passo que a noção de Febvre parece quase objetivar os instrumentos intelectuais, Panofsky pensa o hábito mental como um "conjunto de esquemas inconscientes, de princípios interiorizados que dão a sua unidade às maneiras de pensar de uma época...”. I.e., Panofsky avançou e discutiu os mecanismos que permitem entender como categorias fundamentais do pensamento se interiorizam - e não como algo que "sobre-estrutura" os pensamentos e ações individuais. ${ }^{100}$

\footnotetext{
98 Chartier, A bistória cultural, 1988, p.35.

${ }^{99}$ Ibidem, p.36-37.

100 Ibidem, p.38-39.
} 
Esse processo de interiorização seria discutido por um trabalho considerado fundamental por Chartier - $A$ sociedade da corte, de Norbert Elias, escrito e finalizado nos anos 1930 e publicado apenas três décadas depois. Trabalho que permitiria avançar na noção de habitus (embora apontando para uma ciência que ainda se formaria, a psicologia social, para a qual a noção de representação social é fundamental, embora não interesse aqui adentrar nos meandros dessa discussão).

Nesse livro, percebe-se que o "processo de civilização consiste, antes de mais, na interiorização individual das proibições que, anteriormente, eram impostas do exterior", passando do condicionamento social ao auto-condicionamento (pelos mecanismos de autocontrole sobre as pulsões e paixões). A vida na corte exigia habilidades - propriedades psicológicas - que não são comuns a todos, a dizer, a capacidade de observar os outros e a si mesmos, o controle das paixões, a incorporação das disciplinas que regulam a civilidade. Processo esse de longa duração, não se pode esquecer, e que implica mudanças na estrutura da personalidade - e não apenas nas maneiras de pensar -, na economia psíquica que Elias denominaria por babitus. ${ }^{101}$

\section{Consideracõos finais}

As representações como "pedra angular" da história cultural têm claro valor heurístico, mas, obviamente, não são uma quimera a resolver todos os impasses e dilemas da prática historiográfica. Se é certo que permitiram superar a camisa de força que certas leituras deterministas, estruturalistas, impuseram à compreensão das relações complexas entre a objetividade das condições materiais e a subjetividade da dimensão cultural, não se pode olvidar que novos problemas foram forçosamente levantados.

Problemas que dizem respeito diretamente à possibilidade de a história ser inteligível, i.e., de construir uma narrativa sobre o passado que reconheça a distinção, ainda que fluida, para com a narrativa ficcional. Se se embebe nas ficções, nas criações literárias, nas peças técnicas, nas realizações artísticas ou mesmo nos falseamentos deliberados da história, ainda assim se reconhece na busca, para lembrar

101 Ibidem, p.110-113. 
Paul Ricouer, pelo regime de veracidade que é próprio ao contrato do historiador em relação ao passado.

Assim, negar o apagamento das tênues linhas entre história e ficção parece ser, mais do que um procedimento metodológico e conceitual, uma postura ética, moral. Deste modo, mais do que uma receita para a prática historiográfica, a aproximação ao conceito de representações constitui, sim, um campo de problemas cujos esforços para se desvencilhar tem mostrado resultados profícuos - para entender a dinâmica das relações entre as dimensões econômicas, políticas, sociais, culturais.

Esforços que são cruciais para entender a apropriação, a circulação e a construção de imaginários e imaginações urbanas, questões essenciais para a configuração da história das cidades brasileiras. 
CAPÍTULO 1

\section{LEITURAS VIAJANTES}

A cidade colonial entre olhares estrangeiros 


\begin{abstract}
"A foreigner, who might chance to land first at this place, on his arrival upon the coast of Brazil, would form a very poor opinion of the state of the population of the country; for, if places like this are called cities, what must the towns and villages be" questiona-se Henry Koster ao chegar a Natal em fins de 1810.

In Travels in Brazil (1816, p.68)
\end{abstract}

Ao arrolar os diversos escritores que trataram do Brasil, Richard Burton, no primeiro capítulo de Explorations of the highlands of the Brazil (1869), destacaria a precisão do relato do seu compatriota Henry Koster, publicado meio século antes. Vindo ao Brasil, em meados de 1809, em busca do clima benfazejo dos trópicos para se curar - possivelmente de tuberculose - Koster ocupara seu tempo em diversas viagens a partir do Recife: visitando os arrabaldes da capital da província de Pernambuco, cruzando a Zona da Mata, atravessando diversas aldeias, povoações, vilas e cidades, adentrando o Sertão (sob os efeitos das secas). Alcançaria ainda São Luís num brigue inglês, passando pelas então províncias da Paraíba, Rio Grande (do Norte), Ceará e Maranhão. Constituiria assim um importante testemunho do que era e das transformações por que passava a vida social, urbana e rural na porção setentrional do território do que viria ainda a ser a nação brasileira.

Resultado das observações guardadas nesse deambular contínuo entre 1809 e 1815, incluindo aí algumas idas e vindas entre o Brasil e a Inglaterra, o longo Travels in Brazil foi publicado em 1816 e logo conheceu êxito, como se pode perceber pelas sucessivas edições: no ano seguinte saiu a segunda edição inglesa, a primeira americana e a primeira alemã; em 1818, publicou-se a edição francesa. Em 1821, o relato de Koster ganhou mais visibilidade com a inclusão do seu texto para ilustrar parte considerável do que hoje é o Nordeste do Brasil no segundo volume da coleção de Jacques Maccarthy, Choix de voyages dans les quatre parties du monde, editado em Paris. ${ }^{1}$

\footnotetext{
$1 \mathrm{O}$ primeiro volume da parte da coleção dedicada às Américas apresenta textos de Samson, Ashe,
} Palmer e Pike; o segundo volume transcreve partes dos textos de Koster e de M. M. Kotzebue; o 
Em 1831, publica-se a segunda edição em alemão, dessa vez na coleção intitulada "viagens importantes", organizada por Wilhelm Harnisch; em 1846, a segunda edição francesa, que serviria de base para a primeira tradução brasileira, a cargo de Antonio C. de A. Pimentel, publicada entre 1898 e 1931 na Revista do Instituto Arqueológico Pernambucano. ${ }^{2}$

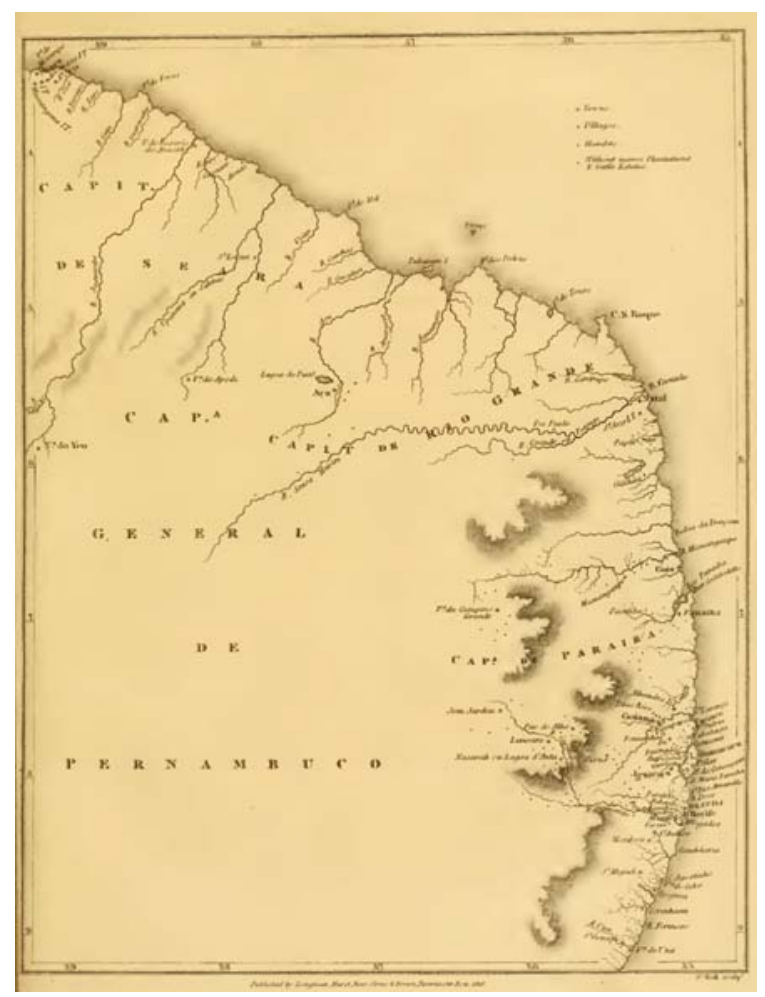

Figura 1.01: mapa da parte setentrional do Brasil, feito a partir de instruções do próprio Koster sobre mapa original de Aaron Arrowsmith. Fonte: H. Koster, Travels in Brazil, 1816.

Não se pode deixar de mencionar que, $\operatorname{logo}$ em 1817, ano da segunda edição do texto original em inglês, é publicada uma longa resenha, composta por transcrições de trechos inteiros, em The Quartely Reviem. ${ }^{3}$ É muito provável que, pelo

terceiro volume, textos de Brackenridge, Maximilian von Wied-Neuwied e Waller (cf. J. Maccarthy, Choix de voyages dans les quatre parties du monde, 1821).

${ }^{2}$ Cf. Câmara Cascudo, Prefácio do tradutor, in H. Koster, Viagens ao Nordeste do Brasil, 1942, p.16-17. A tradução de Antonio Pimentel nunca foi reunida em livro. A edição que serve de referência a este capítulo foi anotada e traduzida por Câmara Cascudo, a partir da segunda edição inglesa, de 1817 (que difere da primeira apenas no uso de gravuras, mapa e planta sem colorização), e cotejada à edição original, disponível no Instituto de Estudos Brasileiros da Universidade de São Paulo.

3 vol. XVI, n. 32, oct.1816-jan.1817, p.344-387. The Quartely Review foi fundada em 1809 pelo conhecido editor londrino John Murray; o journal caracterizou-se como político-literário, de perfil romântico e conservador, congregando autores como Walter Scott e Robert Southey, e no qual se 
conhecimento da bibliografia sobre o Brasil, cotejando o texto de Koster aos de Gaspar Barlaeus , e.g., o autor da resenha tenha sido Robert Southey. ${ }^{4}$

Ademais, o êxito aparece na reverberação e no reconhecimento do livro de Koster nos relatos de outros importantes viajantes, como Auguste de Saint-Hilaire, Tollenare e Robert Southey, além do próprio Richard Burton. Southey - que franqueou a Koster sua biblioteca de 14 mil volumes e muitas raridades sobre o Brasil e que o instou a publicar Travels in Brazil - inclusive o utiliza profusamente no terceiro volume de History of the Brazil (1819). ${ }^{5}$ O secretário da legação diplomática britânica na Argentina e Paraguai, Robert Watson, tinha Koster como uma das poucas referências sobre o Brasil em sua história sobre as Américas portuguesa e hispânica. ${ }^{6}$

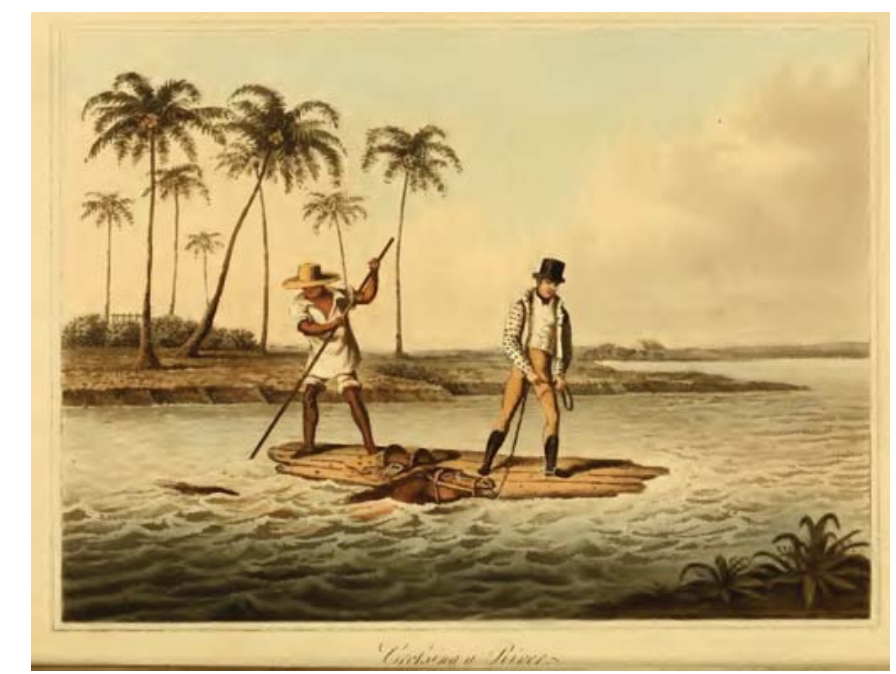

Figura 1.02: "atravessando um rio"; os desenhos de todas as gravuras que ilustram o livro foram feitos por um parente próximo que Koster não nomeia Fonte: H. Koster, Travels in Brazil, 1816.

publicaram resenhas seminais de obras românticas (de J. Austen, Wordsworth, Byron etc.), cf. J. Cutmore, The Quartely Review under Gifford: an overview, Quartely Review Archive, 2007.

${ }^{4}$ De fato, não há evidência da assinatura de Southey; contudo, o Index eletrônico da Quartely Review endossa tal especulação, cf. Quartely Review Archive [disponível em:

http://www.rc.umd.edu/reference/qr/index/32.html], acessado em 12 set. 2007:

"413 Article 4. Koster, Travels in Brazil, 344-87. Author: Robert Southey. Running Title: Koster's Travels in Brazil. Notes: In attributing the article to Southey, Shine cites JM III's Register; Cottle 24243; Southey 577; Water III 484 (that says the article was mutilated), and IV 520 (also says the article was mutilated.) Shine says to see also Warter III 17, 48 and Smiles II 40. The following evidence is published here for the first time. The article appears in Southey's definitive MS. list of his $Q R$ articles. JM III's Register: attribution to Southey, but without evidence".

5 Câmara Cascudo, Prefácio do tradutor, op. cit., p.17-18; C. Harvey Gardner, Introduction, in H. Koster, Travels in Brazil, 1966, p.vii-xvi.

${ }^{6}$ Southey era a principal referência, principalmente no vol. II, quase todo dedicado ao Brasil, cf. R. G. Watson, Spanish and Portuguese South America during the colonial period, 2 vols, 1884. 
De fato, desde logo o relato de Koster consolidaria uma imagem de autoridade e legitimidade; seria considerado como portador de um olhar atento, preciso, acurado, neutro até, pode-se afirmar. Daí a expressão "the accurate Koster", como registraria o capitão Burton, ou “o exato Koster”, como traduziria Câmara Cascudo. A expressão funciona assim como uma metonímia das qualidades e do relevo de Travels in Brazil dentro do vasto conjunto de narrativas de viagens sobre o Brasil colonial e imperial. Cascudo apontaria em seu "prefácio de tradutor":

Henry Koster não é um viajante, caçando anedotas e filmando o pitoresco, nem um naturalista, tendo a investigação anteriormente programada. Não há nele a missão unilateral de estudar um aspecto ou fixar pormenores. Não o subsidia Museu ou Instituto. É uma curiosidade ampla e livre, sem compasso, sem barras, nem limites. É uma criatura humana, vivendo humaníssima e logicamente. ${ }^{7}$

Cascudo lembraria ainda - como ênfase distintiva de outra forma de relato e não como característica negativa - que, ao contrário de outros viajantes como Johann Baptiste von Spix, Carl F. von Martius, Wied-Neuwied e Saint Hillaire - cujas observações eram sistemáticas, perenes, infatigáveis -, Koster “tomava notas sentado na porta da casa grande, pisando o massapé do canavial, cochilando no embalo da rede, sacudido no choto do cavalo tungão, mastigando léguas-de-beiço". Mais adiante, afirmaria, avalizando o narrador:

É a palavra limpa e clara de uma testemunha. (...). Em qualquer capítulo, o exato Koster é fiel, (...).

É um instantâneo sem retoque da época, não do particular ou do escolhido para o quadro, o tema pitoresco, como nos desenhos de Debret ou de Rugendas, mas o total, num corte que abrange os tons e as nuanças, na mesma intensidade do movimento e do colorido. É o indispensável, a voz que atravessou cem anos, ressuscitando Pernambuco e o Sertão, vivendo ombro a ombro mas sem a contaminação dos ódios e dos interesses, das paixões e afetos que parcializam a narrativa, inquinando de suspeição o narrador. ${ }^{8}$

\footnotetext{
${ }^{7}$ Cascudo, Prefácio do tradutor, op. cit., p.09.

8 Ibidem, p.23-24.
} 
Tais referências, escritas no início da década de 1940, além de revelarem muito dos interesses de pesquisador etnógrafo de Câmara Cascudo, são de certa forma um arremate para entender a maneira como Koster vinha sendo lido nos estudos sociais e históricos brasileiros desde finais do século XIX. Uma das fontes fundamentais para a formação da historiografia sobre Pernambuco e Recife em especial, ${ }^{9}$ Koster apareceria citado em Oliveira Lima, e.g., como o retrato fiel para compor as memórias da infância do diplomata - embora essa infância tenha se passado quase sete décadas depois dos relatos do autor inglês; $;^{10}$ em Estevão Pinto, por sua vez, Koster é tomado como um rico repositório de registros da cultura urbana da capital pernambucana na primeira metade do século XIX. ${ }^{11}$

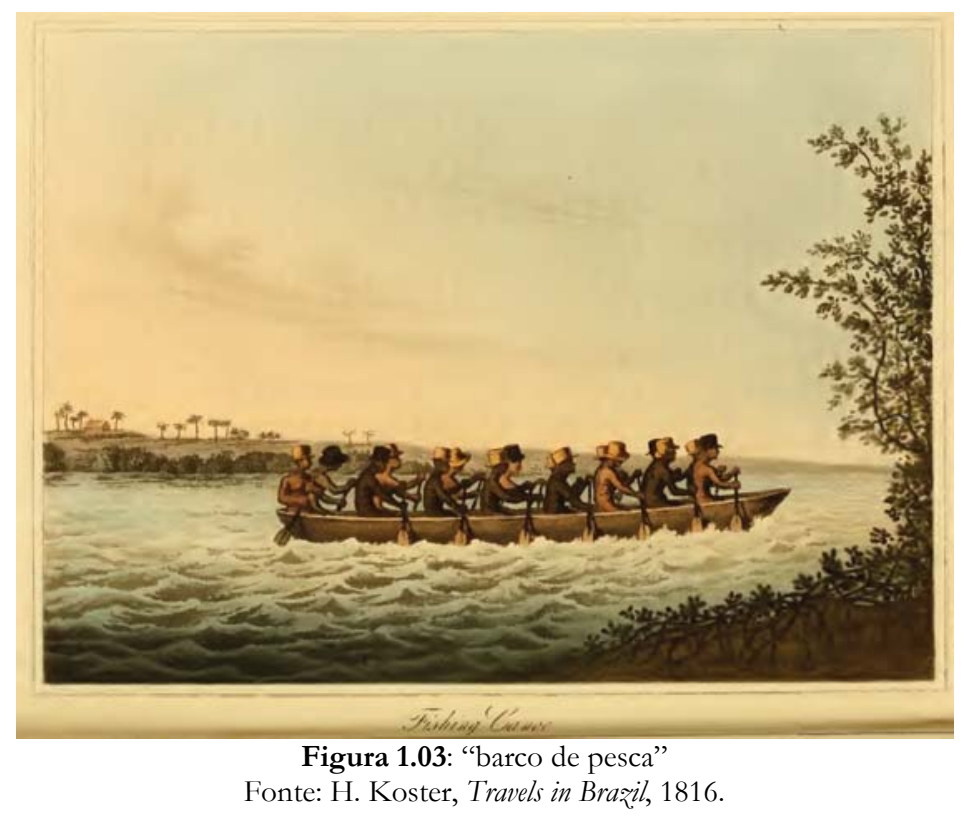

Percebe-se, ainda que de maneira esparsa e difusa, como o texto e as imagens que ilustram o livro de Koster circulam como suporte para discussões etnográficas e para o documentalismo erudito de algumas das práticas historiográficas de meados do século $\mathrm{XX}^{12}$ Outrossim, as observações extensas sobre as condições da

\footnotetext{
${ }^{9}$ Cf. R. Arrais, O pântano e o riacho: a formação do espaço público do Recife no século XIX, 2004.

10 O. Lima, Memórias (estas minhas reminiscências...), 1937, p.94-95; Cf. também Idem, Pernambuco: seu desenvolvimento histórico, 1895, p.220-222, 246, 260.

${ }^{11}$ E. Pinto, Pernambuco no século XIX, 1922, p. 33, 39, 44, 47, 49-50, 127.

12 Cf., e.g., dentre vários, Magazine Eu sei tudo, "A navegação tradicional indígena", maio 1919, p.73; N. Botelho, "Serpentinas e cadeirinhas de arruas", Anais do Museu Histórico Nacional, 1947, p.445-472; F. Lévy, "As mulheres e as armas", Anais do Museu Histórico Nacional, 1947, p.499-522; L. Câmara Cascudo, Rede de dormir. uma pesquisa etnográfica, 1959.
} 
escravidão no Brasil, além da própria experiência de Koster como proprietário rural, levaram o Travels in Brazil a ser uma referência constante nos estudos latinoamericanistas sobre o tema. ${ }^{13}$

Não à toa, Manoel Bomfim o utilizaria para corroborar suas leituras que propunham desmontar o determinismo racial, em especial contra a interpretação de que a miscigenação implicava degeneração, formação de raças inferiores etc. A partir daí, Bomfim comporia, inclusive, certa imagem do que Gilberto Freyre depois chamaria de doçura nas relações entre escravos e senhores. E por que Koster? Porque, ao contrário de autores como Louis Agassiz e suas "veleidades cominatórias, há opiniões de legítimos anglo-saxões; uns de pura ciência, outros historiadores e viajantes, e que, como tal, nos conhecem efetivamente. Koster, que longamente viveu na roça do Brasil - entre gentes de sangue misturado - (...)", era um desses, autor de “trechos de irrecusável realidade, verificada em testemunhos insuspeitos". ${ }^{14}$ Assim,

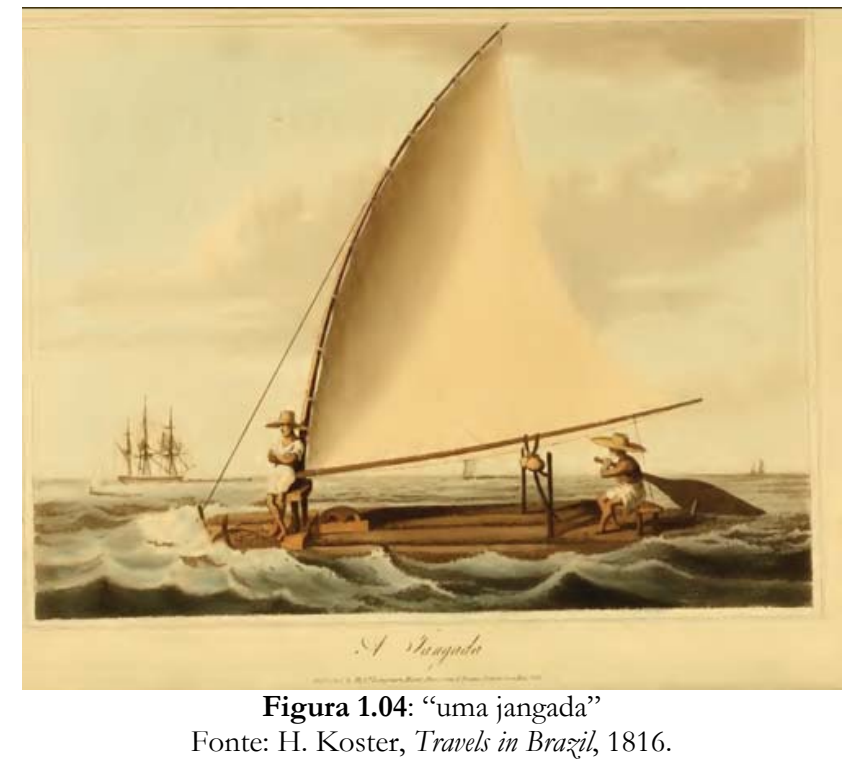

\footnotetext{
${ }^{13}$ Koster trata da questão do negro e do estatuto da escravidão, em especial, nos capítulos XVIII, XIX e XX; a lista de trabalhos que utilizam o relato de Koster é grande e, assim, deixamos registrados alguns, enfatizando os mais antigos encontrados: F. Tannenbaum, The density if the Negro in the Western Hemisphere, Political Science Quartely, mar. 1946, p. 01-41 (registre-se que Tannenbaum é o autor da introdução à primeira edição norte-americana de Sobrados e Mucambos); D. Pierson, The educational process and the Brazilian negro, The American Journal of Sociology, may 1943, p.692-700; J. K. Eads, The negro in Brazil, The Journal of Negro History, oct. 1936, p.365-375; M. W. Williams, The treatment of Negro Slaves in the Brazilian Empire: a comparison with the United States, The Journal of Negro History, jul. 1930, p.315-336. C. Harvey Gardiner, no prefácio à edição norte-americana de 1966 de Travels in Bražil (a primeira desde a edição de 1817), apontaria que tal questão, além da qualidade do texto, era o que mantinha o interesse atemporal pelo livro, cf. Introduction, op. cit., p.xiii.
}

14 M. Bomfim, O Brasil na América, 1997 [1929], p.177-78, 206, 330, 335. 
Koster se tornaria, como apontou Gilberto Freyre em passagem consabida, um dos autores "dos mais merecedores de fé", "arguto observador" da vida social e da cultura urbana do Brasil no início do século XIX. A propósito, é importante registrar o lugar que a literatura dos viajantes teria na obra de Freyre, conforme explicitado na introdução à "Casa-Grande e Senzala":

Para o conhecimento da história social do Brasil não há talvez fonte de informaça mais segura que os livros de viagem de estrangeiros impondo-se, entretanto, muita discriminacão entre os autores superficiais on viciados por preconceitos - os Thévet, os Expilly, os Debadie - e os bons e honestos da marca de Léry, Hans Staden, Koster, Saint-Hilaire, Rendu, Spix, Martius, Burton, Tollenare, Gardner, Mawe, Maria Graham, Kidder, Fletcher. Destes me servi largamente, valendo-me de uma familiaridade com esse gênero não sei se diga literatura - muitos são livros mal-escritos, porém deliciosos na sua candura quase infantil - que data dos meus dias de estudante; das pesquisas para minha tese Social life in Brazil in the midle of the 19th century, apresentada em 1923 à Faculdade de Ciências Políticas e Sociais da Universidade de Colúmbia. ${ }^{15}$

Talvez seja ocioso apontar as dezenas de passagens, tanto em Casa-Grande \& Senzala (1933) quanto em Sobrados e Mucambos (1936), em que Koster é citado. De maneira geral, reitera-se a imagem do viajante que observa com argúcia a vida urbana e nos domínios rurais, os hábitos, as formas de apropriação do espaço das ruas, a descrição da paisagem construída e natural. O historiador da arquitetura Paulo Santos se valeria dessa imagem para incluir o livro de Koster, em meio a outros relatos de viajantes, entre as fontes para estudar a arquitetura do barroco. ${ }^{16}$

Aonde pode levar esse primeiro mapeamento dos usos do relato de Koster? Antes de mais nada, diga-se que não se pretende, assim, afirmar que o seu relato é mais legítimo ou mais arguto e acurado para observar e descrever a sociedade e a paisagem brasileiras em um período histórico crucial para a superação das relações coloniais que haviam marcado até então a história do Brasil; e que, por isso, seria uma fonte mais exata para entender o que e como eram as cidades luso-brasileiras nas duas primeiras décadas do século XIX.

Ao contrário, interessa constatar que a autoridade e legitimidade do texto de Koster se estabeleceu - como um, dentre vários, cuja confiabilidade foi reiterada,

\footnotetext{
15 G. Freyre, Casa-Grande \& Senzala, 2006 [1933], p.47-48.

16 P. Santos, O barroco e o jesuítico na arquitetura do Brasil, 1951, p.223.
} 
permitindo-se o uso como fonte. Processo de legitimação que, como se discutirá adiante, diz respeito tanto aos interesses dos seus leitores quanto a características intrínsecas ao próprio texto assim como às condições e às experiências vividas pelo autor nos mais de dez anos em que morou e viajou no Brasil.

Mas, afinal, o que seriam essas leituras viajantes? São leituras de viajantes, mas, também, leituras que viajam - no tempo e no espaço. O título deste capítulo traz em si a problemática que se pretende enfrentar, a dizer, os usos da vasta bibliografia que os viajantes produziram sobre o Brasil ao longo do século XIX como material fundamental para a constituição de um fundo-comum para a formulação de representações sobre as cidades brasileiras mesmo no século XX. Para tanto, propõese discutir o livro de Henry Koster, Travels in Brazil (1816), como porta de entrada para entender o que e como o chamado "olhar de fora" leu, experimentou e tentou descrever uma paisagem urbana de uma sociedade em mudança. Que imagens de cidades emergem daí? Desses relatos, o que é revelador das estratégias de observação e narrativas do próprio autor (e do sistema cultural a partir do qual fala) e o que é revelador das condições das cidades que ainda começariam os processos de superação do estatuto colonial? Por fim, como essa leitura - cuja própria feitura se deu em viagem - viajou em outros escritos e em outros momentos?

Um problema logo se coloca: é possível estabelecer discussões e análises que, a partir do livro de Koster, permitam generalizações para falar da literatura de viagem como um todo? Ou para delimitar quais representações emergem desse conjunto tão variegado - em nacionalidades, profissões, estratos sociais e interesses? Tal extrapolação não é desejável e, em vários aspectos, não é possível, ou melhor, não é possível sem achatar as diferenças, as idiossincrasias, a dimensão subjetiva de cada relato. Mesmo assim, defende-se aqui, é possível encontrar indícios, ênfases que foram sendo construídas, fundos e lugares-comuns que se estruturaram, tópicas, usos, circulações de temas, imagens, palavras.

Assim, antes de se discutir mais detidamente o livro de Koster, é importante tecer algumas considerações sobre a própria condição da chamada literatura de viagem, "gênero" em que se inscreve o relato aqui discutido.

Antes ainda, deve-se registrar que, apesar do uso reiterado de Travels in Brazil, pouco se avançou em pesquisas e estudos sobre o próprio Koster. O delineamento 
da "biografia impossível" no prefácio de Câmara Cascudo à primeira edição do texto de Koster reunida em livro, de 1942, permanece. "Biografia" que se baseia largamente na "Biblioteca Exótico-Brasileira" de Alfredo de Carvalho (vol. III, 1930). Alguns dados a mais seriam compulsados por Gilberto Freyre, em "Ingleses no Brasil", de 1948. Esse conjunto de informações é a base para o verbete sobre Koster no recente "Dicionário do Brasil Joanino". ${ }^{17}$

\subsection{Literaturas formativas}

Ainda em meados do século XVIII, a literatura de viagem era considerada muito mais como ficção ou mesmo como mentira, um "gênero" literário cujos limites entre realidade e falsificação não eram muito distinguíveis. Daí o antigo ditado que se usava, como bem lembra o historiador Amílcar Torrão Filho, e caía muito bem a um conjunto emaranhado de textos em que se cruzavam diversas tradições e estratégias narrativas: "À beau mentir qui vient de loin" (mente à vontade quem vem de longe). ${ }^{18}$

Diversidade que, ainda assim, reconhecem vários autores, constitui um gênero literário definível, apesar de suas fronteiras flexíveis, sem maiores rigores, um "gênero sem lei" enfim, que comporta vários formatos e estruturas, assim como a própria ficção, e que sofre ainda os influxos dos interesses dos autores e dos editores. Afinal, há uma distância considerável entre a escrita do relato, o preparo da publicação, as adaptações editoriais, a encomenda de gravuras (o que inclui os vários passos do trabalho de impressão), até o resultado final, em forma de livro ou álbum que implicavam também diferentes formatos, tamanhos, acabamentos, alguns mais acessíveis, outros mais luxuosos.

Ademais, o fato de a ficção ter se apropriado dos relatos e do temário da viagem ajudou, de certa maneira, a consolidar uma leitura de indistinção entre gêneros. Como não pensar, e.g., na "Utopia" (1516), de Thomas Morus, em "Os

\footnotetext{
${ }^{17}$ R. Vainfas, "Henry Koster" [verbete], in R. Vainfas e L. B. P. das Neves, Dicionário do Brasil Joanino, 2008, p.194-196. A edição norte-americana de 1966 de Travels in Brą̧il, organizada por C. Harvey Gardiner, baseia-se extensivamente no prefácio de Câmara Cascudo e apenas avança nas especulações das relações entre Southey e Koster.

18 A. Torrão Filho, A arquitetura da alteridade: a cidade luso-brasileira na literatura de viagem (1783-1845), 2008, p.30-33.
} 
Lusíadas" (1572), de Luis de Camões, ou mesmo em "As viagens de Gulliver" (1726), de Jonathan Swift, em meio a um período de produção e circulação de muitos relatos? Apesar das diferenças cruciais (temporais, culturais, de formas de expressão) entre essas obras, há um ponto comum que lhe servem de base: o deslocamento no tempo e no espaço possibilita falar do outro e, como num jogo de espelhos, serve para se refletir e se medir. Viajar pressupunha - como pressupõe - estabelecer e diferenciar o zênite do lugar de quem fala e daquele outro para onde se desloca.

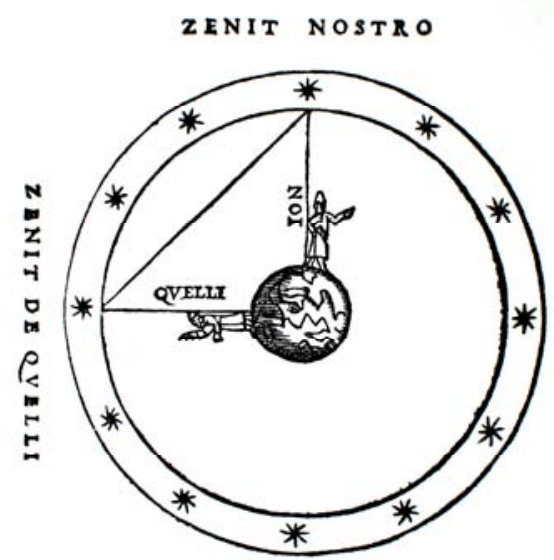

Figura 1.05: [anônimo] Zenit nostro e zenit di quelli, ilustração da Lettera, de A. Vespúcio a P. Soderini. Fonte: Belluzzo, O Brasil dos viajantes, v.2, p.15 1999.

Embora não caiba a essa pesquisa abordar tal questão, não deixa de ser instigante imaginar o efeito desses relatos nos círculos intelectuais ou mesmo entre os letrados nos extratos sociais mais populares. Afinal, sabe-se do impacto das leituras das "viagens de Mandeville" para o universo mental tardo-medieval. Mesmo um moleiro, já na segunda metade do século XVI, com certa independência de pensamento pôde se maravilhar e quedar confuso com a descrição de tantos povos e credos diferentes. ${ }^{19}$ Nesse sentido, se fosse possível explorar essa perspectiva, caberia ver com detalhes a lista de livros dos grandes editores que atuaram, e.g., na formação da chamada Bibliothèque Bleue na França, a partir do século XVII; assim como, dos editores britânicos que trabalhavam com os chamados chaptbooks e dos espanhóis, com os pliegos de cordel. Fórmula editorial, de edição a baixo preço e com capa azul, que foi fundamental para a popularização do livro como objeto. Os textos

\footnotetext{
${ }^{19}$ Cf. C. Ginzburg, O queijo e os vermes, 2005 [1976], p.90-100.
} 
selecionados eram predominantemente religiosos e de ficção (literatura romanesca, romances de cavalaria, etc.). ${ }^{20}$ Algo dos relatos de viagem foram adaptados para essas edições voltadas às classes populares?

Não é possível responder a essa pergunta no momento. De qualquer maneira, sabe-se que a produção dos próprios portugueses sobre o Brasil teve pouca repercussão - devido ao sigilo extremo em relação a qualquer informação sobre os recursos naturais da maior colônia ultramarina. Obras relevantes seriam reconhecidas apenas a posteriori, como as cartas de José de Anchieta (e suas descrições naturalistas e indagações filosóficas da natureza), escritas na década de 1560 e publicadas apenas em 1799, em latim. A obra de Fernão Cardim, "Do Clima e Terra do Brasil e de algumas coisas notáveis que se acham assim na terra como no mar", possivelmente escrita no início do século XVII, só viria a lume em 1939. Intervalos enormes entre a produção do texto e sua posterior publicação também se dariam com as obras do padre Gaspar Afonso e de Gabriel Soares de Souza. Uma exceção foi o livro de Pero Magalhães Gandavo. Publicado em 1576, em Lisboa, todavia parece ter interessado mais pelo registro do maravilhoso, de certa "sensibilidade fantasiosa", a se considerar a repercussão e reprodução em edições populares de imagens como do monstro marinho Ipupiara, que teria sido avistado na costa de São Vicente. ${ }^{21}$

Tal quadro começaria a mudar apenas na segunda metade do século XVIII, com o financiamento pela Coroa Portuguesa da "Viagem Philosophica", de Alexandre Rodrigues Ferreira, realizada entre 1783 e 1793 com o objetivo de estabelecer um conhecimento exaustivo sobre as riquezas do Brasil. Mesmo assim, o material resultante dessa importante expedição permanece ainda inédito. Assim, não

\footnotetext{
${ }^{20}$ R. Chartier, "Textos e edições: a literatura de cordel", in A bistória cultural, 1988, p.165-172; as pesquisas etnográficas do final do século XIX e mesmo até meados do XX puderam identificar, como o faria Câmara Cascudo e, antes, Franklin Távora (na série de artigos intitulados "Lendas e tradições populares do norte", publicados na Illustração Brasileira entre 1876 e 1877), Silvio Romero, Afonso Arinos, Gustavo Barroso, etc., temas heróicos oriundos d'Os Lusíadas, de O Dom Quixote e mesmo do Decameron, dentre outros, no cancioneiro popular, nos desafios dos cantadores, nas longas narrativas poéticas tradicionais do sertão, cf. L. C. Cascudo, Vaqueiros e cantadores: folclore poético do sertão do Ceará, Paraíba, Rio Grande do Norte e Pernambuco, 2000 [1939].

21 Ana M. de M. Belluzzo, O Brasil dos viajantes, 1999, vol. II, p.48; embora publicadas mais de dois séculos depois de sua feitura, pode-se dizer que as cartas de Anchieta, ou melhor, pelo menos as representações jesuíticas acerca da natureza da América circularam tanto pelos deslocamentos geográficos quanto pelas atividades (de divulgação, catequese, embates políticos, etc.) dos próprios membros da Companhia de Jesus desde a sua fundação, por vários estados europeus e colônias americanas, como se depreende do estudo de P. de Assunção, A terra dos Brasis: a natureza da América portuguesa vista pelos primeiros jesuitas (1549-1596), 2000.
} 
é surpreendente que tenha sido a "História Natural" de Marggraf, publicada por Laet em 1648, o material de referência principal sobre a natureza do Brasil ao ser usado por Carl von Linné na proposição do seu Systema Naturae, em $1758 .{ }^{22}$

Imiscuída à literatura de ficção, eivada pela tradição do fantástico, do maravilhoso, do bestiário medieval, que marcara sobremodo os relatos do primeiro século dos descobrimentos, colocava-se como imperativo a superação e a distinção da literatura de viagem - como um gênero verossímil, confiável, objetivo até. Afinal, ilimitada como "sistema de representação", o registro do maravilhoso era facilmente "perecível [como] formulação histórica específica"; 23 i.e., diante das necessidades pragmáticas da navegação, e.g., tais formulações pouco serviam.

Já, pois, no início do século XVII, os interesses crescentes e os fluxos comerciais constantes entre os Países Baixos e o Brasil estão na raiz do esforço de investigação mais aprofundada da natureza da América. Mesmo inseridos dentro de um sistema cultural de uma "operação colonial dominadora", os desenhos e pinturas de Frans Post e Albert Eckhout expressam um avanço significativo em relação às alegorias, ou mesmo caricaturas, anteriores. ${ }^{24}$ De fato, como discute a historiadora Ana de Moraes Belluzzo, os holandeses, marcados pela emergência de uma cultura humanista, levaram a uma nova concepção de imagem cujo conhecimento se construiu baseado nos sentidos. A observação e a descrição da natureza não seriam mais mediadas por uma concepção religiosa ou fatalista, ao contrário, buscava-se apreender o mundo sensível tomado como "imagem da realidade" - imagem que se constrói e que se refere "aos simulacros visíveis dos corpos, às emanações das coisas no espaço, ao vazio que torna possível a visão dos corpos". 25

\footnotetext{
22 Ana M. de M. Belluzzo, O Brasil dos viajantes, 1999, vol. II, p.09-10, 17, 48-49, 64 et seq.; A. Torrão Filho, $A$ arquitetura da alteridade: a cidade luso-brasileira na literatura de viagem (1783-1845), 2008, p.02. Parte significativa da documentação produzida por Rodrigues Ferreira encontra-se na Biblioteca Nacional, no Rio de Janeiro.

${ }_{23}$ G. Giucci, Viajantes do maravilhoso: o novo mundo, 1992, p.16.

${ }^{24}$ E. Stols, A iconografia do Brasil nos países baixos do século XVI ao século XX: uma tentativa de avaliação global, Revista USP, 1996, p.23-26.

25 Ana M. de M. Belluzzo, O Brasil dos viajantes, 1999, vol. I, p.113; cf. também José Leite, Viajantes do imaginário: a América vista da Europa, Revista USP, jun.-ago. 1996, p.34.
} 
Os desenhos e pinturas resultantes dessa pesquisa pela apreensão do mundo sensível iriam, por fim, compor uma primeira memória visual sistemática sobre a paisagem do Brasil. E, apesar do empirismo e do registro que busca a representação naturalista, há muitas convenções que se movem em meio à destreza técnica e criatividade de composição dos pintores holandeses que acompanharam a corte de Mauricio de Nassau. Mas, observe-se, esse processo é de mão-dupla: se, por um lado, as alegorias de Albert Eckhout são instrutivas para entender como as pinturas expressam um sistema de poder, recuperando estratégias retóricas de alegorias anteriores e misturando temas e figuras da área de influência da Companhia das Índias Ocidentais; por outro e ao mesmo tempo, essa alegorias se compõem sobre o registro (que poderia ser chamado de) etnográfico dos diversos grupos indígenas feitos pelo mesmo Eckhout. Da mesma forma, se a paleta de Frans Post se movia inicialmente na composição de uma luminosidade difusa, revestindo a paisagem brasileira de uma atmosfera holandesa esmaecida, muitos quadros posteriores, mesmo pintados na Europa, apresentariam a luz contrastada e as cores mais saturadas dos trópicos. ${ }^{26}$

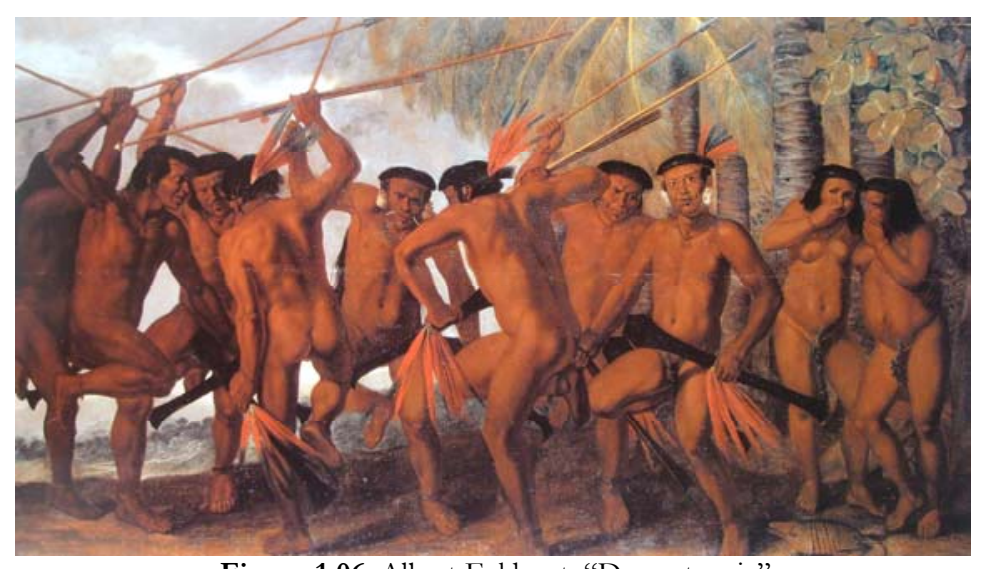

Figura 1.06: Albert Eckhout, "Dança tapuia" Fonte: Belluzzo, O Brasil dos viajantes, 1999, v.1, p.95

${ }^{26}$ Ana M. de M. Belluzzo, O Brasil dos viajantes, 1999, vol. I, p.88-139 passim. 
Assim, sabe-se que a literatura de viagem circulou nos meios letrados, ilustrados. Circulação não mediada mais pelo maravilhoso tão-somente; ao contrário, colocava-se a necessidade de afiançar a veracidade dos relatos. No século XVIII, em especial, vários autores do gênero buscariam delimitar instruções e procedimentos precisos para os viajantes.

Conhecido pela publicação de Questions de statistique à l'usage des voyageurs, de 1795, o conde de Volney tornou-se uma referência para essa discussão, ${ }^{27}$ propondo um método que afirmaria a importância fundamental da experiência sensorial para reconhecer a "materialidade do mundo". Como discute
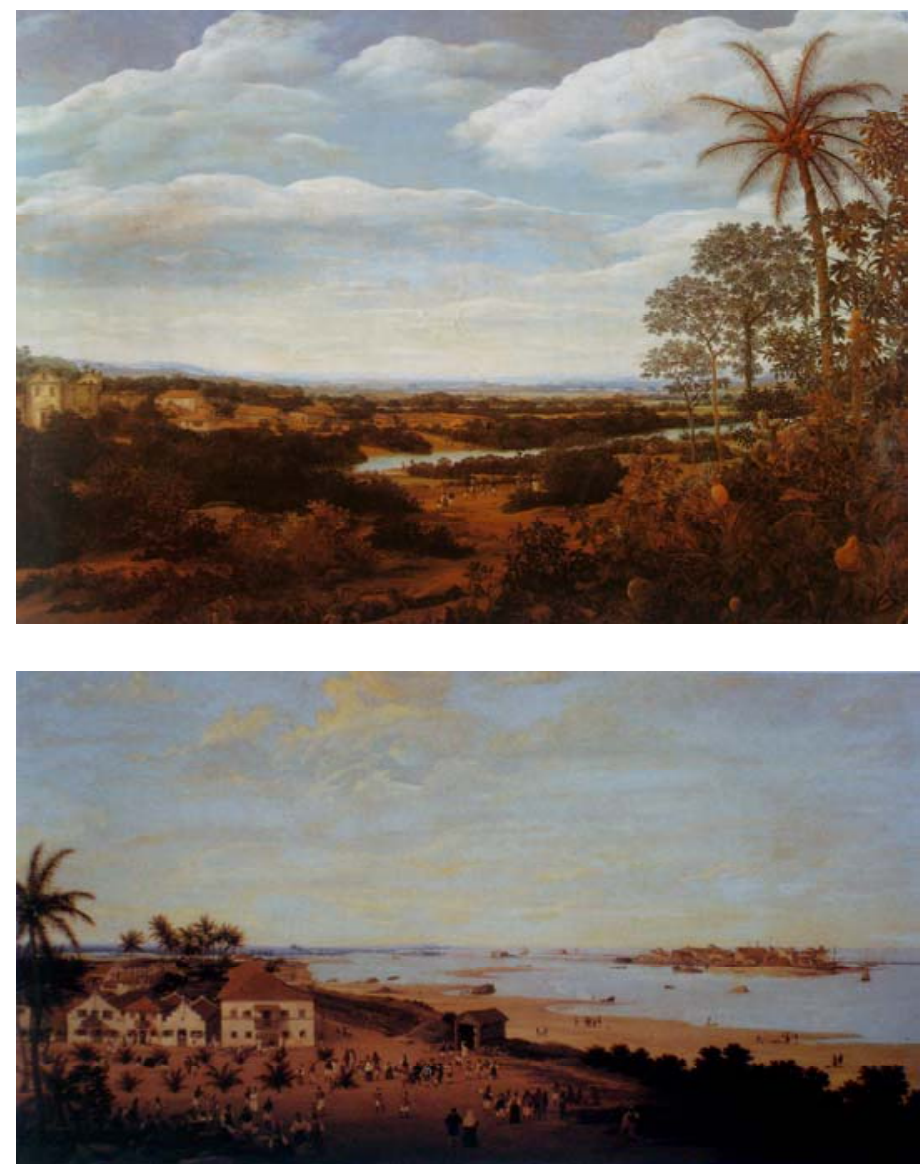

Figura 1.07 (acima): Frans Post, "paisagem com jibóia”, óleo sobre tela Fonte: Belluzzo, O Brasil dos viajantes, v.1, p.127.

Figura 1.08 (abaixo): Frans Post, "Mauritsstadt e Recife, 1653", óleo sobre madeira Fonte: Belluzzo, O Brasil dos viajantes, v.1, p.124.

o historiador Amílcar

Torrão Filho,

O que Volney vai buscar no Oriente, que rejeita na Europa do circuito conhecido do Grand Tour pela Itália, e recupera na América numa espécie de exílio mais ou menos forçado alguns anos depois, é a alteridade, a diferença que opõe as antípodas da civilização e define suas marcas e suas fronteiras, sendo, ao fim, o objetivo de quase toda viagem. Essa alteridade se constrói textualmente pela tradução do outro ao mesmo, da analogia, da

27 Os relatos da viagem de Volney à Síria e Egito (publicados em 1787) faziam parte dos livros lidos por aqueles que se dirigiam ao Norte da África e ao Oriente Médio, serviam como porta de entrada aos deslocamentos geográficos, cf. D. Manley, Two brides: the Baroness Menu von Minutoli and Mrs Colonel Elwood, in Travellers in Egypt, 2001, p.97. 
comparação, da inversão. O que desejo destacar nesta construção textual de uma representação da diferença é que ao tratar do outro, o viajante edifica uma representação de si mesmo. ${ }^{28}$

Deriva de Volney também a formulação - que se tornaria um lugar-comum de que o olhar do viajante estrangeiro perceberia melhor as sensações do lugar, as singularidades, porque capaz de comparar, de contrastar e se espantar, ao passo que o habitante local, imerso no cotidiano, não teria parâmetro para julgar. ${ }^{29}$ Funda-se na possibilidade de reconhecer a alteridade, ainda que num registro hierárquico, a legitimidade do viajante.

Fundava-se também na capacidade de ver e descrever o visto, inserindo-se em um sistema de referências e auto-referências que assim se legitimavam. Ver o que já fora visto e descrito constituía, a princípio, um atestado de autenticidade do relato - como a dizer a seus leitores: "eu estive de fato lá”. O jovem naturalista Alcide D’Orbigny, nos seus relatos das viagens pelas Américas, a cargo do Museu de História Natural de Paris, não apenas se filiaria à "viagem-modelo" do projeto humboldtiano como também faria várias considerações acerca da bibliografia disponível sobre o Brasil nos anos 1820. Destacaria os relatos do príncipe Maximillian von Wied-Neuwied, Saint-Hilaire, o Barão Georg Langsdorff e, em especial, os extensos textos de Spix e Martius, além dos diários sem maiores objetivos científicos de Maria Graham e J. Mawe, dentre outros. ${ }^{30}$

\footnotetext{
28 A. Torrão Filho, A arquitetura da alteridade: a cidade luso-brasileira na literatura de viagem (1783-1845), 2008, p.03-04.

${ }^{29}$ Ibidem., p.02; não se pode deixar de notar que essa formulação ecoa noções e textos ainda mais antigos, que dizem respeito ao "estranhamento" como procedimento (literário, filosófico, etc.) para atingir o âmago das coisas, como Montaigne o faria, no texto "Dos canibais" (1580), ao relatar as impressões dos três índios brasileiros levados à França: “(...) incapazes de perceber o óbvio, tinham visto algo que costuma ser ocultado pelo hábito e pela convenção. Essa incapacidade de tomar a realidade como ponto pacifico deliciou Montaigne", lembra-nos Carlo Ginzburg, Estranhamento: pré-história de um procedimento literário, Olhos de Madeira: nove reflexões sobre a distância, 2001, p.29, grifos nossos.

30 A. D’Orbigny, Viagem pitoresca através do Brasil, 1976, p.30-31; curiosamente, mostrando-se conhecedor do relato de muitos viajantes britânicos, ainda assim D’Orbigny não cita Koster.
} 
A proliferação de tantos relatos levaria, inclusive, a uma espécie de retomada das discussões sobre as tópicas de viagem, sobre como observar e descrever. Mas, no lugar das instruções de método mais voltadas aos cientistas, a ênfase seria posta nas maneiras de tratar e descrever uma paisagem pitoresca - mais ao sabor de um crescente público europeu interessado no gênero. Os textos de Julian Jackson são expressivos desse conjunto de preocupações, em especial porque iria apontar a cidade como locus privilegiado para entender determinada sociedade, seu grau de civilização. $^{31}$

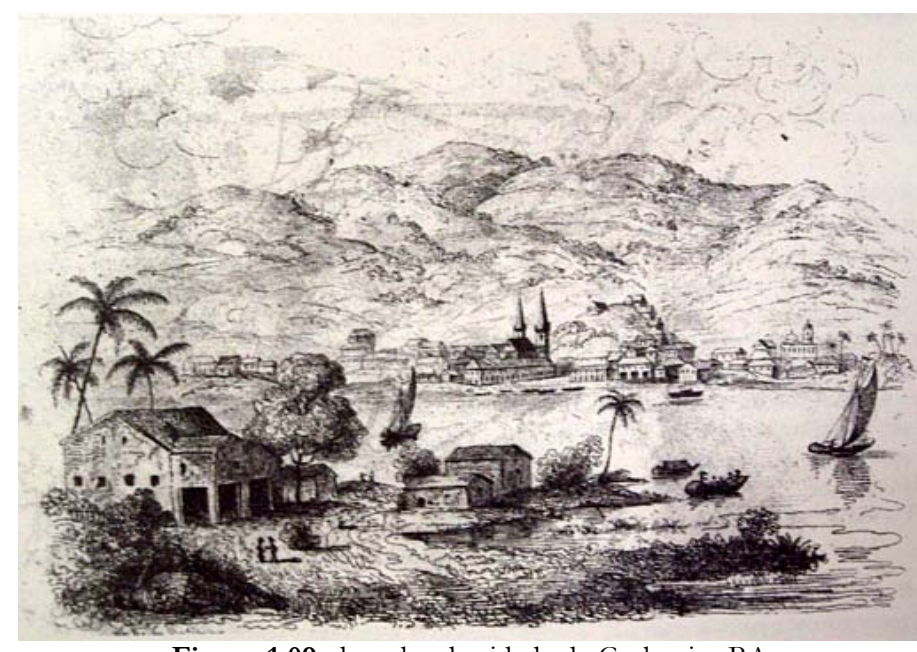

Figura 1.09: desenho da cidade de Cachoeira-BA

Fonte: A. D’Orbigny, Viagem pitoresca através do Brasil, 1976.

Nesse sentido, Jackson, em What to Observe (1841), faz uma advertência que ajuda a iluminar um trecho significativo do livro de Henry Koster: o viajante não deveria se enganar com a nomeação de certos aglomerados urbanos como cidades, pensando que o termo seria correspondente ao que a palavra significava na Europa, afinal há "cidades e cidades principais muito mais insignificantes do que a mais pobre de nossas aldeias". ${ }^{32}$ Escrito mais de 20 anos após a publicação de Travels in Brazil, o trecho de Jackson leva a refletir sobre uma passagem conhecida do livro. Koster, em sua primeira longa viagem, saiu do Recife em finais de 1810 e dirigiu-se a Fortaleza,

${ }^{31}$ J. Jackson, "On picturesque description in books of travels", Journal of the Royal Geographical Society, vol. 5, 1835, p.381-87; e Idem, What to observe, 1841; ambos citados por A. Torrão Filho, op. cit., 2008, e L. Martins, O Rio de Janeiro dos Viajantes, 2001.

32 Apud A. Torrão Filho, A arquitetura da alteridade: a cidade luso-brasileira na literatura de viagem (17831845), 2008, p.147. 
passando por diversas aldeias, vilas e cidades, pousando em casas-grandes e ao relento. Ao chegar a Natal, capital da província do Rio Grande do Norte, Koster quedou espantando:

Cheguei às onze horas da manhã à cidade do Natal, situada sobre a margem do Rio Grande ou Potengi. Um estrangeiro que, por acaso, venha a desembarcar nesse ponto, chegando nessa costa do Brasil, teria um opinião desagradável do estado da população nesse País, porque, se lugares como esse são chamados de cidades, como seriam as vilas e aldeias?33

É certo que muito desse espanto de Koster é retórico, estratégia narrativa também usada em outras partes do livro - que busca transmitir as sensações primeiras (de hesitação, surpresa, receio etc.) ao leitor. Afinal, na seqüência do parágrafo, o reparo é estabelecido - a partir da tópica das terras do Novo Mundo como terra da promissão:

Esse julgamento não havia de ser fundamentado e certo porque muitas aldeias, no Brasil mesmo, ultrapassam esta cidade. O predicamento não lhe foi dado pelo que é, ou pelo que haja sido, mas na expectativa do que venha a ser no futuro. ${ }^{34}$

Ao contrário, o predicamento fora dado pelo lugar que Natal ocupara na estratégia do controle geopolítico português sobre a parte setentrional Brasil entre o final do século XVI e primeiras décadas do XVII, sob a unificação das duas coroas ibéricas. No limite, pode-se especular, apagava-se ou se desconsiderava a história precedente, como errática, em prol de uma história a construir, prospectiva, que se vislumbrava no horizonte, a partir da abertura dos portos - processo essencial para, na leitura de Koster, o avanço civilizacional do país. O seu livro constrói-se também nessa perspectiva, como testemunho dos significados progressistas advindos do estreitamento com o comércio britânico, sobremaneira.

Independente de conhecer esse trecho ou não do Travels in Brazil, a advertência de Jackson chamava a atenção para um problema comum na composição dos relatos de viagem: a necessidade do deslocamento semântico e não apenas geográfico. As palavras nem sempre eram tão precisas. Deslocamento que é,

\footnotetext{
${ }^{33}$ H. Koster, Viagens ao Nordeste do Brasil, 1942 [1816], p.109; grifos nossos.

${ }^{34}$ Ibidem, p.109-10.
} 
portanto, essencial para entender a maneira como as cidades luso-brasileiras foram lidas. Há, ademais, outra chave de leitura fundamental que se depreende desse trecho do livro de Koster, a dizer, a relação direta entre a paisagem e os usos da cidade e as formas de organização social, o estágio civilizacional de determinado povo.

Koster, assim, movia-se no terreno de uma das principais "instruções perceptivas" discutidas ao longo do século XVIII, nas reflexões sobre a arte de viajar e na possibilidade de ler a cidade como espaço (ou principal expressão) da alteridade, como apareceriam nos textos do próprio Conde de Volney, no Instruction for travellers (1758), do deão anglicano Josiah Tucker, ou no ambicioso texto de Leopold Bertchold, Patriotic Traveller (1789), dentre vários outros. ${ }^{35}$ Essas perceptivas teriam largo uso na discussão sobre as cidades no Brasil, cujo paroxismo - em chave negativa - muito provavelmente é o livro do Conde de Suzannet.

Nem mesmo a chegada ao Rio de Janeiro impressionara o francês, ao contrário do que se usava ler - como o próprio Suzannet leu - em outro relatos. Curioso contraste que se estabelece com o livro de David Kidder e James Fletcher, quase contemporâneos. Para o Conde de Suzannet, a vasta baía da Guanabara não permitia um olhar que abarcasse a paisagem, deixando o espectador indeciso, ao contrário do espetáculo imponente de Nápoles e Constantinopla. Kidder e Fletcher, por sua vez, afirmam a proeminência da baía da cidade do Rio de Janeiro sobre as outras duas. Sempre citadas pelos muitos turistas viajantes, pela beleza, extensão e sublimidade do cenário, a do Rio de Janeiro teria a vantagem de ser emoldurada por uma atmosfera de "verão perpétuo", pelas montanhas de um pitoresco único e pelo verde dos trópicos. ${ }^{36}$

\footnotetext{
35 A. Torrão Filho, op. cit., p.121-141 passim.

36 De Suzannet, O Brasil em 1845, 1957, p.21; D. P. Kidder e J. C. Fletcher, Brazil and the Brazilians, 1857, p.13-20.
} 
A cidade, por sua vez, na leitura de Suzannet, era a expressão do descuido, da indolência, da irregularidade de formação do brasileiro. A longa citação que se segue permite entender o uso de tópicas recorrentes que formariam lugares-comuns de vasta ressonância na historiografia brasileira - aqui, ressalte-se, opera uma síntese depreciativa:

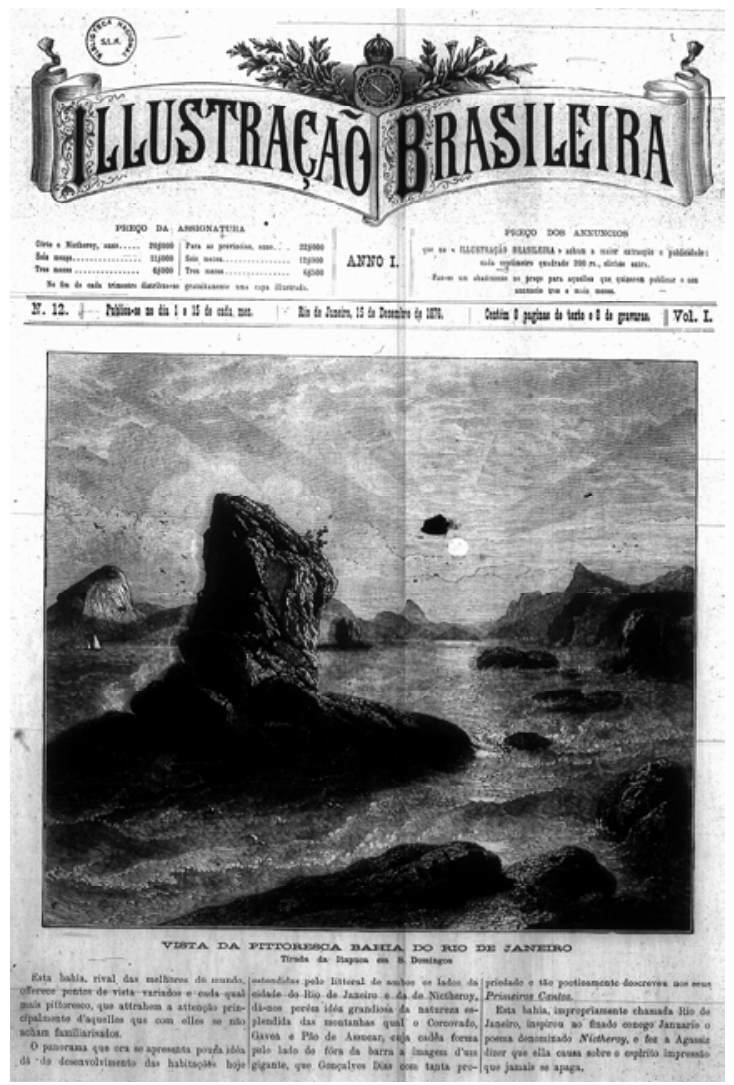

Figura 1.10: vista da "pitoresca" baía do Rio de Janeiro Fonte: A Illustração Brasileira, 15 dez. 1876.

A cidade do Rio tem a forma de um quadrado irregular e fica situada às margens da baía. A sua construção é toda nova, pois a sua importância data apenas de um século. O único monumento notável é o aqueduto que traz as águas do Corcovado (Carcoval) à fonte da Carioca. (...). O palácio do Imperador é um grande edifício quadrado sem arquitetura. As igrejas, os diversos monumentos destinados aos serviços públicos são construídos com solidez, mas sem elegância. Quanto às praças principais da cidade, são irregulares e mal construídas, só tendo de notável o tamanho. Um jardim sombreado por árvores é o único passeio no centro da cidade, mas, graças aos hábitos indolentes dos brasileiros, está sempre deserto. As ruas sujas e estreitas de casas que raras vezes têm mais de um andar, mal calçadas e desiguais, tornam qualquer excursão, a pé ou de carro, difícil e cansativa. 


\section{$[\ldots]$.}

Como costumes e como figuras típicas, as ruas do Rio não têm aspectos característicos: negros e europeus mal vestidos, pesados cabriolés puxados por mulas, nada merece atenção. $O$ canto triste e monótono dos negros que transportam as sacas de café causam uma desagradável impressão. 37

O prazer do deambular se encontraria nos arrabaldes - Botafogo e Catete, principalmente, onde residiam os ministros estrangeiros: "o ar é tão puro, a vegetação em redor das 'vilas' tão rica e variada, que a vida se torna agradável e fácil; (...); por toda a parte descobrem-se recantos encantadores, panoramas admiráveis; em toda parte a natureza tropical seduz pela graça ou surpreende pela grandeza". ${ }^{38}$

As caminhadas, como meio para cultivar o corpo e o espírito, ressoam longa tradição, marcada, ao longo do Setecentos e nas primeiras décadas do século XIX, pela sensibilidade romântica, pela noção do pitoresco. Esses substratos culturais, ainda que imprecisos, não fechados como sistema e de usos cada vez mais largos, teriam grande circulação nas maneiras de ler e, consequentemente, na própria conformação da paisagem do Brasil - tributária tanto da apreciação estética quanto do projeto de investigação metódica e totalizante da natureza do iluminismo, cuja síntese encontra-se na vasta obra do naturalista Alexander Humboldt.

Contudo, constatar esses substratos culturais predominantes é suficiente para analisar o conjunto de relatos dos viajantes ou de um texto singular, como o de Koster? Na verdade, servem de ponto de partida para entender como temas, sistemas de conhecimento, maneiras de olhar e narrar foram apropriados em determinados contextos e sob determinadas circunstâncias. De qualquer maneira, é nesses substratos que se embebeu também, direta ou indiretamente, o livro Travels in Brazil, como se percebe pela estrutura narrativa do texto, revelando a emergência de um novo observador no século XIX.

\footnotetext{
37 De Suzannet, O Brasil em 1845, 1957, p.27-28.

38 Ibidem, p.29.
} 


\section{2 o observador que participa}

O relato de Koster é copioso, devido as suas muitas e extensas viagens e, principalmente, ao interesse pelo detalhe, pela minúcia, pelos pormenores, pelo anedotário, que permeiam e dão cor a sua leitura do todo, ao esforço de compreensão abrangente da região. A sua condição de viajante "não interessado" parece ter revestido de neutralidade ou imparcialidade seu relato, i.e., seria visto como não deformado por objetivos apriorísticos, por motivações imperialistas ou pelo furor classificatório das nascentes disciplinas científicas modernas, como a biologia. Afinal, Koster nem era um artista que buscava ampliar sua paleta e experimentar para abarcar novas cores, formas e texturas; nem era o naturalista interessado em descobrir, catalogar, dissecar; muito menos o militar interessado em ampliar, detalhar e precisar a cartografia náutica; ou o "colonialista" pensando geopoliticamente; ou ainda o colecionador de coisas exóticas e pitorescas.

De fato, nada disso constrange o relato singular de Koster. Esse mover-se "desinteressado" intrigava até mesmo aqueles com quem tomara contato. Em São Luís, e.g., escreveu:

Tive grande dificuldade em convencer aqueles com quem conversava que não tinha negócios a tratar. Não compreendiam o motivo que levava o homem a aturar tantos incômodos para passear e tantos inconvenientes para divertir-se. Muita gente não se convenceu, certa que eu dissimulava e teria planos sinistros. ${ }^{39}$

Desnecessário enfatizar que outros interesses se revelam nesse desinteresse. Se Koster não é artista, cientista, militar-cartógrafo ou colecionador, o seu relato embebe-se num momento de início da profissionalização do olhar em direção à natureza, um momento de emergência do "observador moderno" ou do "observador-em-trânsito". ${ }^{40}$ Observador que traz, assim, algo de artista, cientista, militar-cartógrafo e colecionador, cujas ferramentas de análise e descrição são construídas no embate com o objeto a ser examinado, descrito, objeto muitas vezes novo, desconhecido, como as paisagens de uma terra distante (no tempo e no espaço) - para o viajante estrangeiro.

\footnotetext{
${ }^{39}$ H. Koster, Viagens ao Nordeste do Brasil, 1942, cap. IX, p.246.

${ }^{40}$ L. Martins, O Rio de Janeiro dos viajantes: o olhar britanico (1800-1850), 2001, p.11-16; cf. também Flora M. Lahuerta, Viajantes e a construção de uma idéia de Brasil no ocaso da colonização (1808-1822), Scripta Nova: Revista Electrónica de Geografia y Ciencias Sociales, ago. 2006.
} 
Há de se ponderar ainda que esse "desinteresse" é, claramente, uma ênfase de leitura posterior, sobremaneira de Câmara Cascudo. ${ }^{41}$ Afinal, não se pode desconsiderar que, para além das narrativas de viagem propriamente dita, Koster pontificou (no capítulo XXI, o último) sobre os tratados comerciais entre Brasil, Portugal e Inglaterra, argumentando a favor do incentivo à fixação de estrangeiros no país e do incremento do comércio entre as partes, o que traria benefícios claros à colônia. Harvey Gardiner chamaria a atenção para os interesses comerciais de Koster que podem ser entrevistos em meio ao relato, principalmente quando trata das suas relações em Recife. ${ }^{42}$ Ademais, no longo apêndice, Koster incorporou a sua própria tradução de dois estudos botânicos do religioso carmelita Manuel de Arruda da Câmara, selecionando os trechos que mais interessariam aos "leitores ingleses": o primeiro, dedicado às plantas do Brasil; e o segundo, à utilidade de estabelecer jardins nas províncias do país. ${ }^{43}$

Cabe assim estabelecer uma ressalva acerca da leitura de Koster por Cascudo. Primeiro, mesmo no caso dos viajantes-cientistas, com programação de pesquisa préestabelecida, com objetivos de caminhos, coletas, etc. a realizar, esses não (apenas) constrangeram seus objetos (estranhos, novos) ao conhecimento pré-existente; esse conhecimento forçosamente se expandiu no embate com o novo. A programação prévia foi constantemente posta à prova, revisada, sopesada. Deve-se ter cuidado em apontar esse olhar unilateral, o que Cascudo faz no seu prefácio - para, por oposição, elogiar o "descompromisso" de Koster -, que não seria influenciado pelo que vê (afinal, isso aconteceu em maior ou menor grau com todos).

Em segundo lugar, enfatizar que Koster embrenha-se não apenas na geografia física do território, dos sertões, etc., mas no território das práticas culturais (as festas religiosas, as novenas, o entrudo, etc.) - i.e., ver de dentro, não apenas de fora - aponta muito mais para os interesses de Cascudo pela etnografia histórica, compulsando fontes antigas, recolhendo material que apontasse, direta ou

\footnotetext{
${ }^{41}$ Nos estudos das "permanências", das "constantes" na formação da cultura brasileira, Cascudo se interessaria por esse tipo de relato, que submerge no cotidiano, possibilitado pela longa vivência de Koster no Brasil.

42 C. Harvey Gardiner, Introduction, op. cit., p.ix.

${ }^{43}$ H. Koster, Viagens ao Nordeste do Brasil, 1942 [1816], cap. XXI, p.549-568, e apêndice, p.569-595; interessado nas descrições botânicas de cada espécie, Koster deixa de lado o trecho que "trata das vantagens da instalação no Brasil dos Reais Jardins Botânicos”.
} 
indiretamente, para as tradições orais. Cascudo enfatiza mais ainda que este ver de dentro marcou a forma de observação de Koster: como na atitude desinteressada de tomar notas sentado na porta da casa grande ou cochilando no embalo da rede.

Mesmo assim, o lugar social e cultural do observador Koster pode (e deve) ser marcado. Entretanto, esse aspecto (de estar inserido em um determinado sistema cultural) não pode obscurecer as suas idiossincrasias, a contribuição individual de sua leitura, a especificidade de um olhar em trânsito que busca distanciar-se, embora nem sempre consiga, de uma visão meramente paternalista, que menosprezaria os hábitos e tradições do país que vai visitar.

A "biografia impossível" de Koster dificulta maiores ponderações sobre sua formação, leituras, interesses. Se, de fato, nasceu em 1793, chegou muito jovem ao Brasil - teria 16 anos em 1809. Mas, sabe-se que nasceu em Portugal, onde o pai, inglês, era comerciante. Afirmaria, logo na abertura do livro: "Acrescento que a língua portuguesa me é mais familiar que a do meu país. O leitor sensato dará pouca importância ao estilo de um livro da natureza deste". ${ }^{44}$

Ao contrário, isso aponta para um dado essencial das perceptivas de viagem: o tempo longo de permanência e o conhecimento da língua local eram fundamentais para conhecer e apreciar as características de um país, seu gênio e seu caráter, como definiria Volney. ${ }^{45}$ Assim, percebe-se também como as ressalvas ao leitor tem muitas das estratégias retóricas que compartem os relatos de viagem, sobremodo os "não interessados" ou não científicos, filiando-se a uma longa tradição dos próprios relatos de viagem, como se pode perceber nas narrativas. Diria Koster: "Espero que o leitor queira por bem escusar os defeitos que possa descobrir neste livro quando saiba que não fiz observações seguidas no Brasil com pensamento de publicar os resultados". ${ }^{46}$ Nada muito diverso do tipo de ressalva que faria outro comerciante, o francês Arsène Isabelle, acerca das suas viagens pela Argentina, Uruguai e sul do Brasil, entre 1830 e 1834, embora reconhecesse que escrevia para instruir os compatriotas interessados em investir no comércio com esses países; ${ }^{47}$ ou da que faria Carl Nebel em sua Voyage

\footnotetext{
${ }^{44}$ H. Koster, Viagens ao Nordeste do Brasil, 1942 [1816], "prefácio do autor", p.07, grifos nossos.

45 A. Torrão Filho, op. cit., p.135-136.

${ }^{46}$ H. Koster, loc. cit.

47 Arsène Isabelle, Viaje a la Argentina, Uruguay y Brasil, 2001 [1835], p.11-25.
} 
Pittoresque pelo México - “(...) esta obra não tem nenhum objetivo científico , não esperará pois [o leitor] que uma vista pitoresca seja acompanhada de um artigo científico sobre o México". ${ }^{48}$ Emeric Essex Vidal, aquarelista amador que servia na marinha britânica quando esteve em Buenos Aires - e que acabou sendo o primeiro autor a documentar em imagens a Argentina independente -, também partia da idéia dos registros sem maiores pretensões. Como diria:

(...) el autor de este trabajo se contentó con bosquejos, originalmente sin vistas a publicarlos, algunos rasgos característicos que presentaban las ciudades de Buenos Aires y Montevideo, y aquellas singularidades em las costumbres, maneras e indumentárias de las gentes en la forma más soprendente que se les presentaran durante uma residencia de trés años en el pais. Estos diseños, cree él, resultarán tanto más aceptables a los interesados, cuanto que, a su conocimiento, ninguna ilustración gráfica de esos lugares había sido, hasta ahora, presentada al público. ${ }^{49}$

Essa estratégia comum remete-se também ao processo de legitimação dos relatos viajantes que vinha se processando desde meados do século XVIII, pelo menos. Se a legitimidade não advinha diretamente de um vínculo institucional ou da autoridade científica, derivaria, sim, dos valores inerentes à experiência retratada no texto. Havia assim um público cada vez mais diversificado, interessado nos relatos de tom pessoal, da leitura subjetiva que revelavam uma sensibilidade para o pitoresco, para os costumes, para os elementos desse viver de dentro que poderiam iluminar a alteridade. O "observador-em-trânsito" exacerbaria a tensão entre o olhar de fora e o daquele que reside, o outro, e, por extensão, entre os elementos formativos do sistema cultural de origem do autor e os dados subjetivos que se formam na experiência contínua. ${ }^{50}$ Viver por um longo período no país relatado, falar o mesmo idioma (e, como no caso de Koster, com fluência), era fundamental, como dito acima, para a construção dessa experiência.

\footnotetext{
48 Apud Valéria Souza, Gosto, sensibilidade e objetividade na representação da paisagem urbana nos álbuns ilustrados pelos viajantes europeus: Buenos Aires, Rio de Janeiro e México (1820-1852), 1995, vol. I, p.43.

49 E. Essex Vidal, Buenos Ayres e Montevideo, 1991 [1820], p.13; registre-se que o texto de Vidal e, principalmente, suas imagens teriam grande repercussão na Europa, comporiam de fato o primeiro material gráfico sobre a recente nação Argentina; contudo, o texto seria traduzido e publicado na própria Argentina apenas mais de um século depois, em 1923, cf. Ibidem, p. 09-11.
}

${ }^{50}$ Cf. Luciana Martins, O Rio de Janeiro dos viajantes, 2001, p.21 et seq. 


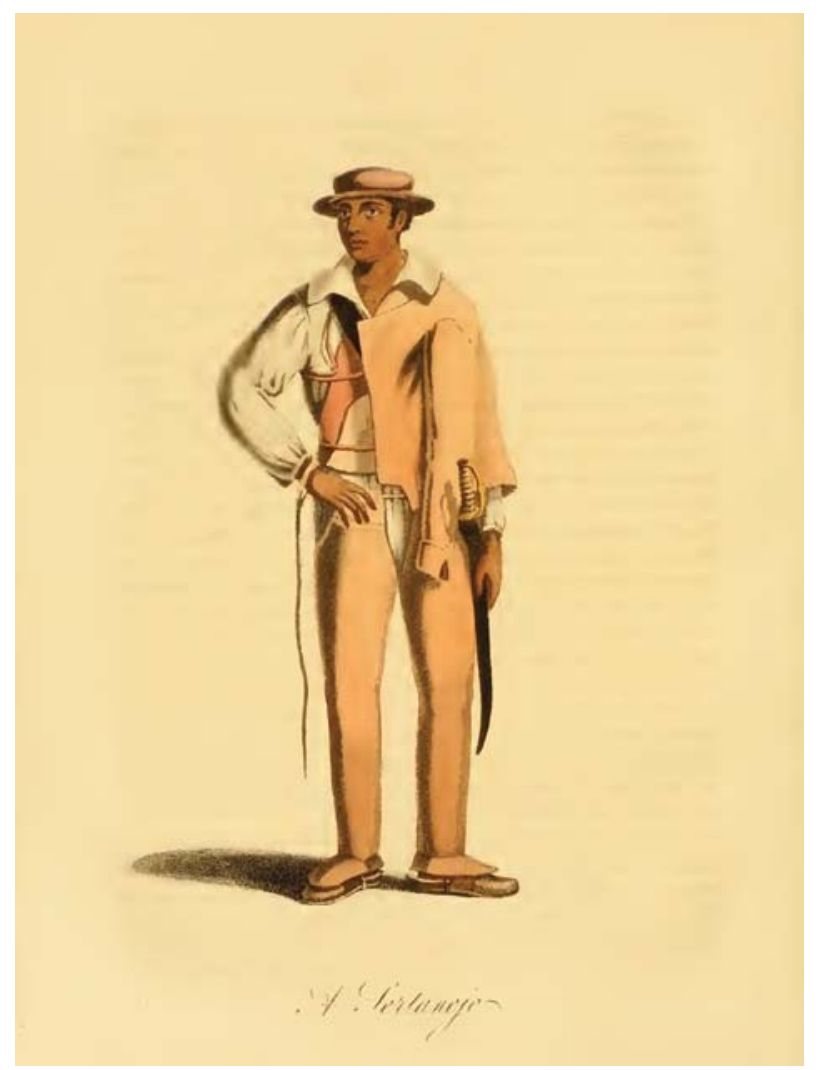

Figura 1.11: o sertanejo e seus apetrechos de couro, alguns dos quais Koster usaria na travessia do sertão sob as secas. Fonte: H. Koster, Travels in Brazil, 1816.

Koster, ao longo de sua primeira grande viagem, iniciada em outubro de 1810 e que o levaria a atravessar o sertão das províncias do Rio Grande do Norte e do Ceará sob período de estiagem, relatou como se apropriaria de certas estratégias para enfrentar o clima e a falta de água:

Minha sede era grande porque não bebera durante a noite anterior. Restavam alguns limões que foram distribuídos, refrigerando-nos muito. Depois do meio-dia, o major sugeriu-me imitar seu exemplo, pondo uma pedrinha na boca, recurso tradicional dos sertanejos em tais ocasiões. Segui seu conselho e o processo produziu considerável umidade. ${ }^{51}$

${ }^{51}$ H. Koster, op. cit., p.127. 
Vivenciar era tão importante quanto a reflexão de gabinete. Experiência que, como expressaria Koster nesse e em outros trechos, fez-se a partir da prática do outro. Assim também o faria o naturalista Joseph Banks, que recomendava expressamente aos seus coletores de plantas nos arredores do Rio de Janeiro que, conquanto jovens e de boa compleição física, conformassem-se "às práticas dos nativos evitando os perigos do clima e os riscos de visitar regiões insalubres". $52 \quad$ William Burchel, naturalista e exímio desenhista e aquarelista, sempre preferia proceder a coleta por conta própria, ver as espécimes em seu próprio habitat a ter que comprá-las dos comerciantes locais. Outro jovem botânico, John Forbes, teve um fim que constitui, de certa forma, um

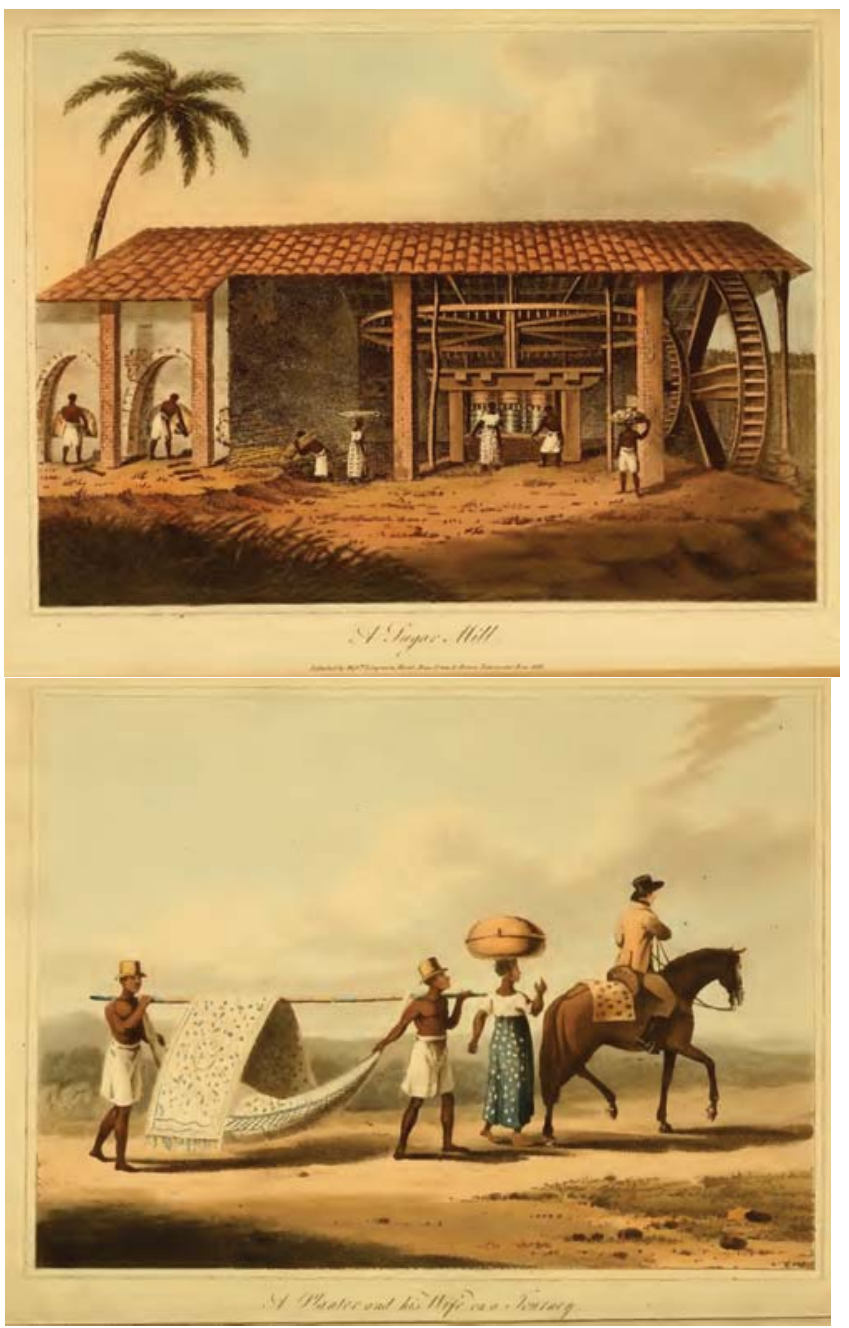

Figura 1.12 (acima): figura de um engenho de cana-de-açúcar (a sugar mill). Fonte: H. Koster, Travels in Brazil, 1816.

Figura 1.13 (abaixo): a viagem de um senhor de engenho e sua esposa, protegida na rede. Fonte: Ibidem.

paroxismo dessa necessidade de vivenciar: após passar por Portugal, parte da costa do Brasil e costa atlântica africana, faleceria ao ingerir um fruto não-comestível durante o levantamento do rio Zambeze. ${ }^{53}$

\footnotetext{
52 Carta de J. Banks a Cunningham e Bowie, 18 set. 1814, apud Luciana Martins, op. cit., p.108.

${ }^{53}$ Cf. Luciana Martins, op. cit., p.110-123; sobre W. Burchel, cf. também G. Ferrez, O Brasil do Primeiro Reinado visto pelo botânico William John Burchell 1825/1829, 1981, que retrata os quase cinco anos de grande produção e longas viagens (Rio de Janeiro, região de Paraíba do Sul, Santos, São Paulo, Goiás Velho até Belém) do pintor e botânico inglês.
} 
Koster não chegaria a tanto, mas reconheceria os perigos dessa imersão no cotidiano que o levara, e.g., a ser "metamorfoseado" em Henrique Costa. O aportuguesamento do nome pelos seus contemporâneos do período como "quase senhor de engenho", entre 1812 e $1815,{ }^{54}$ era apenas a ponta visível de um processo que, temia, poderia levá-lo a sucumbir a um tipo de organização social "feudal". Escrevendo no gabinete de Southey, reconheceria que foi com muita relutância que abandonara o "desejo de residir no Brasil" - o povo, a terra, os seus negros, cavalos, cães, a casa e o jardim, os campos que semeara. Se assim não o fizesse, teria se tornado um lavrador no Brasil. Continua:

\begin{abstract}
A posição que se encontra um homem que governa escravos não é feita para formar a criatura melhor de que seria noutras circunstâncias. Possivelmente eu, em breve tempo, não podia ser membro de outra sociedade. Sentia-me inclinado para a vida que levava. Eu era jovem, era livre e tinha poder. Embora estivesse inteiramente convicto dos males que decorrem de uma sociedade ou estado feudal, amava ter escravos. Poderia tornar-me tão arbitrário como apaixonado por essa existência meio selvagem. Podia ficar sentindo tanto sabor pela ociosidade, não tendo regras, como desgostando tudo que fosse racional e lógico no mundo. ${ }^{55}$
\end{abstract}

Assim, fundando-se na vivência, quer nas práticas científicas dos naturalistas ou nas andanças "descompromissadas" de comerciantes e de gentlemen, como Koster e até mesmo Charles Darwin a princípio seriam, os relatos viajantes superariam as desconfianças que marcaram sua recepção no ambiente intelectual europeu até, grosso modo, meados do século XVIII. Punha-se em xeque, como leitura ultrapassada, inclusive os velhos ditados, como o faria Arsène Isabelle:

"Un viajero - ha dicho Chateaubriand - es una espécie de historiador; su deber es contar fielmente lo que ha visto o lo que ha oído; no debe inventar nada pero tampoco debe omitir nada". $\mathrm{Y}$ en cuando al viejo proverbio: "Quien viene de lejos puede mentir a gusto" ya ridículo de puro viejo, Alcides D’Orbigny le hace justicia com esta reflexión muy sensata:

"Los viajeros se equivocan siempre, sin duda, o pueden equivocarse siempre porque son hombre... pero los viajeros no mienten... Cómo se atreverian a mentir en presencia de un público, por lo general tan desconfiado como instruído, de una

\footnotetext{
${ }^{54}$ Koster arrendou um engenho em Jaguaribe (aproximadamente 24 quilômetros a norte de Recife), em abril de 1812, que manteve até novembro de 1813, quando o proprietário o solicitou; mudou-se para a vila da Conceição, na Ilha de Itamaracá, onde retomou a atividade de cultivar canaviais - essa experiência é retratada extensivamente nos capítulos XI a XV, cf. H. Koster, Travels in Brazil, 1816.

${ }^{55}$ H. Koster, Viagens ao Nordeste do Brasil, 1942, p.417; grifos nossos.
} 
crítica siempre despierta y de una prensa dispuesta a revelar sus imposturas?". 56

É certo que essa experiência seria sopesada nas viagens de ida e volta, como se revela na história da edição de Travels in Brąil. Após sua longa viagem entre fins de 1810 e início de 1811, Koster retornaria à Inglaterra em abril. Em dezembro desse mesmo ano, aportaria novamente em Recife. Em 1815, foi chamado de volta à Inglaterra. ${ }^{57}$ É nessa ocasião que foi instado a publicar em forma de livro as notas que colhera no Brasil. Instado por Robert Southey, a quem dedica o livro. Southey faculta-lhe o uso de sua própria biblioteca, um portento de mais de 14 mil volumes, com diversas preciosidades bibliográficas sobre o Novo Mundo. É nesse ambiente, em Keswick, Cumberland, consultando o próprio History of Brazil, cujo primeiro volume tinha sido publicado em 1810, além de números do Correio Brąiliense e de $O$ Investigador Portuguer, dentre muitos outros títulos, que Koster escreveria seu livro, entre 1815 e 1816.

A proximidade com Southey, que Gardiner aventa tenha sido estabelecida ainda quando da passagem do poeta inglês por Portugal, levado pelo seu tio materno, o pastor anglicano Herbert Hill (que foi quem lhe legou parte da futura grande biblioteca), ou quando do primeiro breve retorno de Koster à Inglaterra, em 1811, seria importante ainda para viabilizar a publicação, abrindo-lhe as portas da editora. ${ }^{58}$ A casa londrina Longman, Hurst, Rees, Orme \& Brown, além de publicar o próprio Southey, já tinha um catálogo com mais de uma dezena de títulos de narrativas de viagem, incluindo Maria Graham (Journal of a residence in India e Letters on India), John Scott, traduções de Humboldt (The personal narrative of $M$. de Humboldt's Travels to the Equinocial Regions of the New Continent, during the years 1799-1804), que supervisionara essa tradução, além de relatos dedicados à China, ao atual Afeganistão, à Tessália, Albânia, à descoberta dos afluentes do Nilo e mesmo à viagens pela Grã-Bretanha, França, Grécia e Estados Unidos. A resenha elogiosa que Southey escreveu na The

\footnotetext{
56 A. Isabelle, Viaje a la Argentina, Uruguay y Brasil, 2001 [1835], p. 22.

${ }^{57}$ L. Câmara Cascudo, Prefácio do tradutor, in Viagens ao Nordeste do Brasil, 1942, p. 12-15. Koster é sempre muito lacônico sobre suas relações pessoais com Portugal e Inglaterra, uma das razões para conformar sua "biografia impossível"; nesse trecho, diria apenas: "Pouco tempo depois recebi notícias da Inglaterra que tornavam necessária minha volta ao lar" (Koster, Viagens ao Nordeste do Brasil, 1942, p.417).

${ }^{58}$ C. Harvey Gardiner, Introduction, op. cit., p.x-xi.
} 
Quartely Review, como mencionado no início deste capítulo, ajudaria na pronta circulação do livro.

Assim, apesar da diferenciação (baseada na dimensão da vida cotidiana) buscada por esse tipo de narrador, o vínculo institucional ou mesmo oficial seria ainda fundamental para inserir o texto numa trama de autoridade e referência. Trama que revela diversas paisagens urbanas, como será discutido a seguir.

\subsection{Narrar a cidade, viver a cidade}

Pouco mais de um mês após a partida de Liverpool, o navio que trazia Koster se aproximou da costa pernambucana. Os cuidados necessários para adentrar o porto de Recife permitem-no olhar com vagar a paisagem no horizonte:

A costa é baixa e, consequentemente, não pode ser vista vindo do mar, senão a uma certa distância. Aproximando-nos distinguimos, um pouco ao norte, a colina sobre que está situada a cidade de Olinda e, algumas léguas ao sul, o cabo de S. Agostinho. Em seguida, descobrimos, quase diante de nós a vila de Santo Antonio do Recife e os navios ancorados sob seus muros, as terras desertas e estéreis que a separam de Olinda, que está a uma légua (.....59

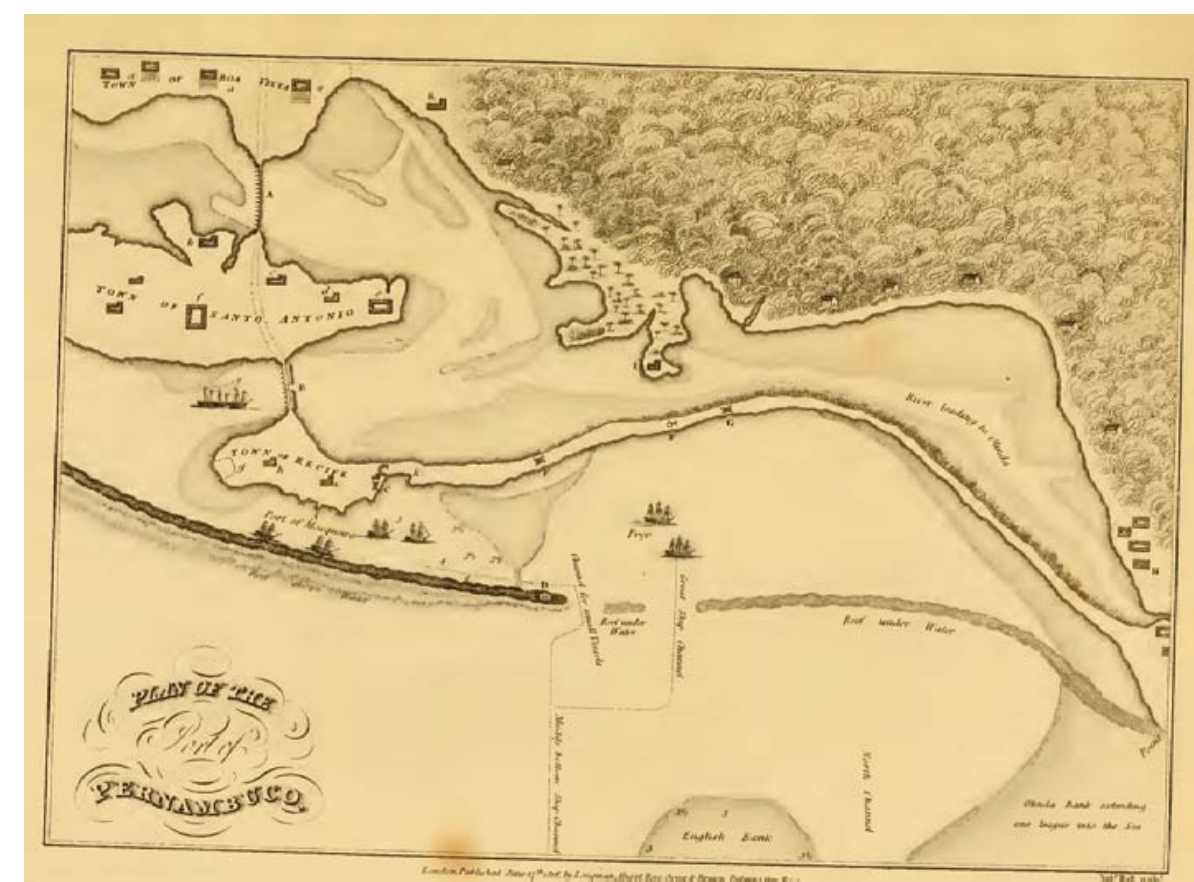

Figura 1.14: planta do porto de Recife; o interesse do registro é pragmático (para navegação e praticagem) e, assim, apenas insinua a ocupação urbana. Fonte: H. Koster, Travels in Brazill, 1816.

${ }^{59}$ Koster, op. cit., cap. I, p.30. 
A estratégia de narrativa é clara. Koster conduz o olhar e tenta reconstruir e transmitir ao leitor as sensações da primeira visada do Novo Mundo. Acaba revelando o que não se podia saber ainda (e.g., a referência às "terras estéreis e desertas" entre Recife e Olinda). O afã de informar embaralha notas de viagem, memória e o redigir ponderado e fechado em um gabinete, realizado a posteriori. Continua Koster, atento agora à paisagem urbana:

A cidade de Olinda é construída sobre um outeiro: sua situação, observada do mar, é do mais agradável efeito. Igrejas e conventos que se elevam sobre os cimos e os flancos da colina, seus jardins e suas árvores, semeados aqui e ali entre as casas, dão a mais alta idéia de sua beleza e extensão. $\mathrm{O}$ aspecto monótono da areia, que se estendem a uma légua ao sul, é interrompido pelos dois fortes que ali construíram e pelos navios ancorados no porto inferior. ${ }^{60}$

Recife demora a se descortinar. Olhando à esquerda, a cidade, "si "surgindo sobre o banco de areia muito baixo, parece sair das ondas". O tema da cidade (ou, melhor, do elemento urbano) que surge, mal-e-mal, entre os elementos naturais, com certo embotamento, um embaralhar-se entre os dados artificiais e naturais (esses normalmente em primeiro plano), não é incomum no registro gráfico dos viajantesartistas. ${ }^{62}$ Havia aí tanto a permanência das vistas construídas a partir do mar, das entradas, de um quadro gráfico construído à distância com claro sentido pragmático (para orientar os navegantes sobre os principais acidentes geográficos a particularizar uma costa, como, e.g., o faria Robert Burford na sua descrição da Baía do Rio de Janeiro, em 1825); ${ }^{63}$ quanto o interesse na visão que abarca o todo, fundado na “concepção humboldtiana da paisagem", em busca de uma "espacialidade panorâmica" - de um observador que se posta à distância e constrói o registro totalizante da paisagem, mas, ao mesmo tempo, a conhece de dentro e a penetra. ${ }^{64}$

\footnotetext{
${ }^{60}$ Ibidem.

${ }^{61}$ Quando Koster viveu no Brasil, Recife ainda era (formalmente) uma vila; seria elevada à condição de cidade em 1823 (Câmara Cascudo, 1942, cap. I, nota 1, p.39).

62 Cf. os estudos de Rugendas, e.g., para Vila Nova de Imperatriz-MG (1824) e para a Baía de Botafogo, no Rio de Janeiro (1822-25), in Maria Costa e Pablo Diener, A América de Rugendas, 1999, p.99.

${ }^{63}$ A imagem panorâmica de Burford encontra-se no capítulo 2 desta tese.

${ }^{64}$ Humboldt consideraria Rugendas o "criador da arte de representação da fisionomia da natureza", cf. Ana Maria Belluzzo, O Brasil dos viajantes, vol. II, p.21-24, 124.
} 
Contudo, as cores, os cheiros, os sons urbanos da nova terra alcançam os viajantes antes do desembarque, aumentando a sensação de confusão e estranhamento. O bote, ocupado por "negros quase nus", que acompanhava o piloto responsável pela praticagem responde por essa antecipação:

A cor desses homens, o estado em que se encontravam, seus clamores sonoros, sua agitação sem motivo, sua inaptidão, eram outras tantas novidades para mim. (...). Essa primeira comunicação com a terra me deu, no momento, a idéia de que as maneiras do povo que ia visitar eram ainda mais estranhas que realmente as encontrei. ${ }^{65}$
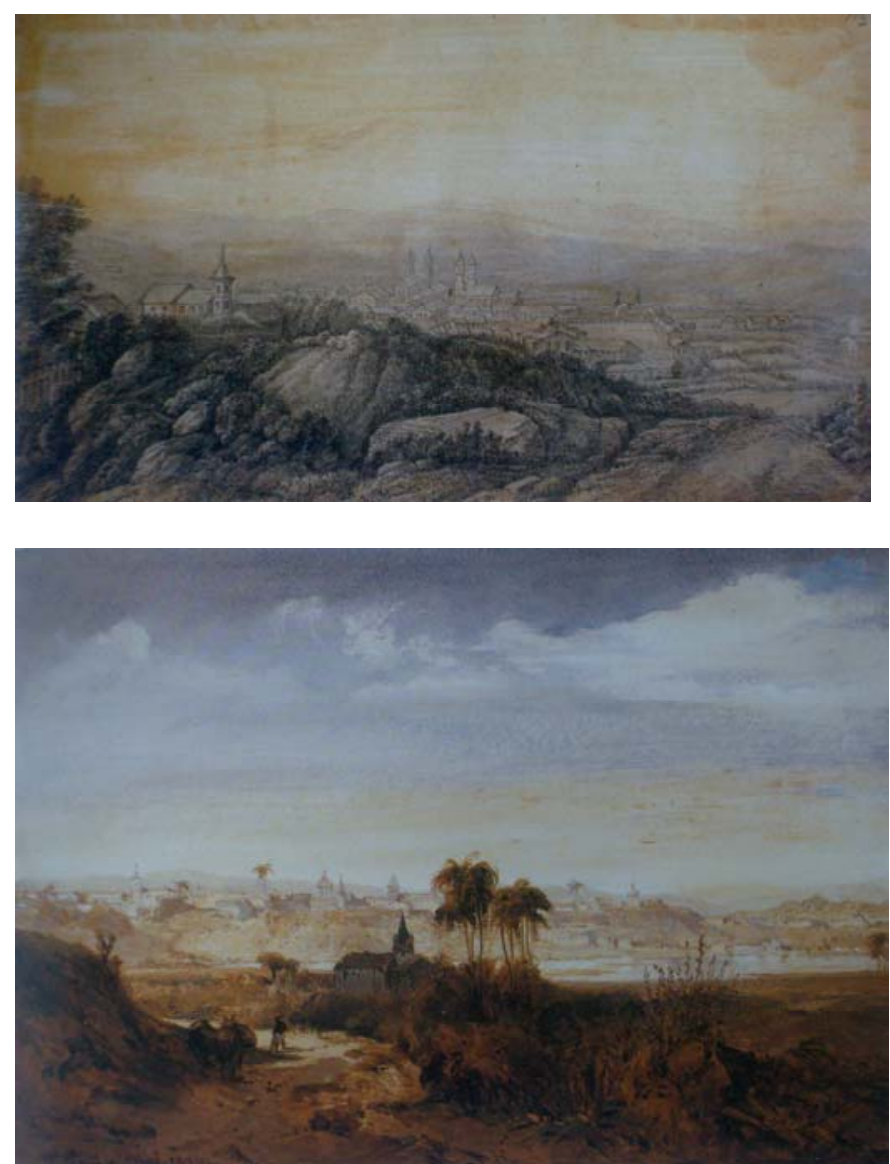

Figura 1.15 (acima): atribuido a von Martius, "Mariana", lapis e pena sobre o papel.

Fonte: Belluzzo, O Brasil dos viajantes, 1999, v.2, p.115.

Figura 1.16 (abaixo): Edouard Hidelbrandt, "São Paulo", 1844, óleo e aquarela sobre papel.

Fonte: Ibidem, v.3, p.105.

${ }^{65}$ Koster, op. cit., p.32. 
Em terra, no cais da Alfândega, a sensação de confusão apenas aumenta. A azáfama de um dia de muito movimento é pontuada continuamente pelos sons ditos, berros, versos, perguntas - e pela agitação que os negros faziam, uma "feia algazarra", diria Koster. Embora chame a atenção para a população negra, preponderante nas ruas, essa algaravia e falta de ordem não lhe era exclusiva e se estendia às mais diversas ocasiões e grupos sociais, como registrou em jantares sociais e festas religiosas. ${ }^{66}$ Depois, parece aceitar a "confusão" como parte da dinâmica urbana. Quando finalmente se instala, assevera (com um quê de ironia):

Eis-nos, portanto, tranquilamente instalados em nossa nova residência, tão tranquilamente como possa estar alguém quando uma vintena de negras grita sob as janelas, em todos os tons de que a voz humana é capaz, laranja, banana, doces e outras mercadorias para vender. ${ }^{67}$

Fisicamente, a vila de Santo Antonio do Recife, "comumente chamada de Pernambuco", aparece para Koster como uma articulação (por duas pontes) entre as duas ilhas e a porção do continente ao sul, configurando os três "bairros":

O primeiro bairro da cidade [Recife propriamente dito] é composto de casas de tijolos, com três, quatro e mesmo cinco andares. Estreitas em sua maioria, as ruas, as mais velhas moradas nas ruas menores não tem senão um andar. Um grande número possui apenas o térreo. Todas as ruas desse bairro, exceção de uma apenas, são calçadas. Na praça encontram-se a Alfândega, num dos ângulos, edifício longo, mesquinho e baixo; o prédio da Inspeção do Açúcar nada tem de notável, uma grande Igreja inacabada, um café onde os comerciantes se reúnem para seus tratos, e as casas particulares. ${ }^{68}$

Após passar a antiga ponte de arcos de pedra e madeira, estreitada pelas pequenas lojas que a ladeavam, Koster chega a Santo Antonio, bairro central e o "principal" da cidade, que compreendia casas altas, ruas largas, muitas praças, diversos prédios públicos (Palácio do Governo, Tesouraria, Casa de Câmara e Cadeia, casernas) e espaços religiosos (os conventos de carmelitas, franciscanos e da

\footnotetext{
${ }^{66}$ Cf. e.g. Ibidem, cap. II, p.47, 50, 52, cap. XI, p.304; ao registrar os ritos, festas, usos e costumes durante a Semana Santa de 1810, lembraria que "no sábado, pela manhã, [fora acordado] pelos mugidos dos bois, grunhidos de porcos e grito das escravas negras, com cestos de galinhas e muitas coisas para vender" (p.49).

${ }^{67}$ Ibidem, cap. I, p.33.

${ }^{68}$ Ibidem, p.34.
} 
Penha, além de várias igrejas). Havia também "uma certa impressão de viveza e alegria", a despeito da arquitetura pouco graciosa das residências e das igrejas. O conjunto é desproporcional, na leitura de Koster: os edifícios "são muito altos para sua largura e a parte térrea serve para lojas, armazéns, oficinas, cocheiras e outros usos semelhantes. As lojas não têm janelas. Recebem luz unicamente pela porta. (...). Algumas das ruas menores têm casas mesquinhas e baixas". ${ }^{69}$

O terceiro bairro é o de Boa Vista. Além da rua central, "formosa e larga", muitas casas pequenas, esparsas, estendem-se pelo território, cuja indistinção é ampliada pela falta de calçamento das ruas (assim como as de Santo Antônio, mas naquele bairro a trama urbana está consolidada e a paisagem conformada pelos quarteirões de edifícios altos sem afastamentos).

O uso do espaço das ruas, dos largos, das praças, é marcado, na leitura de Koster, tanto pela presença profusa dos negros e a balbúrdia daí decorrente quanto pela não-presença feminina (pelo menos, das mulheres brancas, portuguesas e brasileiras, e das mulatas livres). Esse tema é recorrente ao longo do livro - e central para parte da historiografia brasileira que discute a herança colonial na estrutura das relações sociais urbanas pós-independência. Ao observar as residências com atenção, Koster escreve:

\begin{abstract}
Algumas janelas das casas têm vidraças e balcões de ferro, mas a maioria não os possui e os balcões são cobertos de gelosias. Não se vêem mulheres além das escravas negras, o que dá um aspecto sombrio às ruas. As mulheres portuguesas e as brasileiras, e mesmo as mulatas de classe média, não chegam à porta de casa durante o dia. Ouvem a Missa pela madrugada, e não saem senão em palanquins, ou à tarde, a pé, quando, ocasionalmente, a família faz um passeio..$^{70}$
\end{abstract}

De fato, vários viajantes, além do próprio Koster, iriam anotar e enfatizar esse aspecto de reclusão, que aparece como um signo claro do atraso causado pelas estruturas (sociais, econômicas e sobretudo culturais) do período colonial, principalmente pela sociabilidade do mundo rural. ${ }^{71}$ Tema que marcaria, depois, a

\footnotetext{
${ }^{69}$ Ibidem, p.35.

${ }^{70}$ Ibidem, cap. I, p.36.

${ }^{71}$ Paulo Marins põe em xeque tal representação, problematizando o lugar-comum do tema da reclusão, buscando compreender as motivações e o "metro" comparativo dos viajantes, inseridos em outro sistema cultural de valores de civilização; nesse sentido, o "uso social" das rótulas dava-se "não como
} 
própria constituição da história da arquitetura moderna brasileira - como se percebe nos muitos estudos de Robert Smith sobre a documentação baiana (publicados na Revista do IPHAN) ou nas interpretações de Philip Goodwin sobre o "isolamento exclusivista" das famílias latinas (que ajudaria a entender a aceitação franca dos brisesoleils como permanência do usos das antigas rótulas e gelosias) e de Henrique Mindlin acerca da "influência mourisca" na construção das cidades luso-brasileiras, como será discutido no capítulo 4.

Ao jantar num engenho, no caminho entre Goiana e João Pessoa (então Cidade da Paraíba), Koster atestaria de forma inequívoca:

\begin{abstract}
Jantamos uma ocasião com o proprietário do engenho Mussumbu. Este senhor, várias outras pessoas e eu, estávamos à mesa em uma sala enquanto as senhoras, as quais não era permitido sequer trocar um olhar, serviam-se num aposento adjacente. (...). O dono desse domínio é português. É entre essa parte da população, que deixou seu país para fazer fortuna no Brasil, que a introdução de melhoramentos é quase impossível. Muitos brasileiros também, mesmo de classe superior, seguem os costumes mouriscos, de sujeição e reclusão mas, tendo alguma comunicação com a cidade, vêem depressa que é preciso preferir maneiras mais civilizadas e rapidamente possuem hábitos de polidez. ${ }^{72}$
\end{abstract}

Além do tema clássico da reclusão (decorrente da influência ibérica), esse registro interessa de perto pela observação de que é na cidade que a civilidade pode se fazer. Em meio às várias observações sobre os muitos núcleos urbanos que percorre, Koster registra o início de uma mudança de percepção em relação à cidade. De arremedo do mundo rural, passa a ser considerada lócus de novos hábitos e usos necessários a uma nova nação, aberta, a se civilizar.

algo que cindia espaços, dimensões e sociabilidades, mas que, ao contrário da interpretação tradicional, servia à sua união", Cf. Através da rótula, 2001, p.33.

${ }^{72}$ Koster, op. cit., cap. IV, p.83 
De fato, esse passo é decisivo na construção do texto de Koster. As idas e vindas entre Brasil e Inglaterra permitir-lhe-iam mostrar como a vinda da Corte para o país e, principalmente, a abertura dos portos tinham levado, em curto espaço de tempo, a mudanças de hábitos, costumes e usos sociais do espaço urbano e do comportamento privado - "alargando-se o espírito" com leituras, novos tecidos e vestimentas, itens de cutelaria e serviços de mesa etc. - em direção a padrões civilizados. $^{73}$

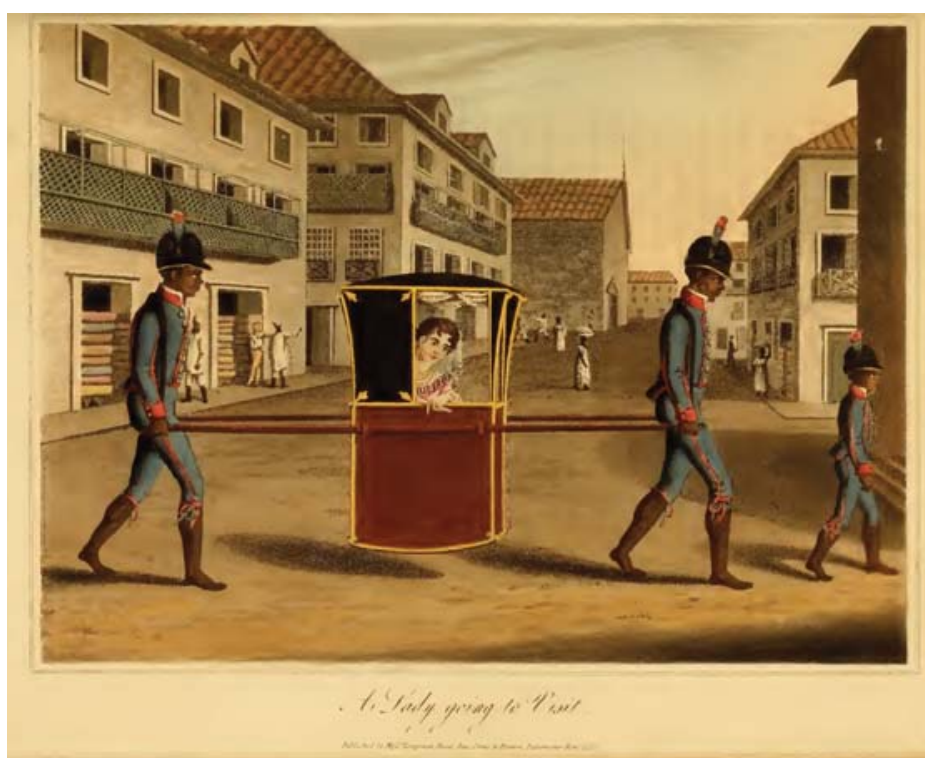

Figura 1.17: rua indefinida do Recife, com algumas características centrais, como as gelosias e balcões, contudo o desenho a partir de uma descrição esmaece a dinâmica da vida urbana. Fonte: Koster, Travels in Bražil, 1816.

Esse alargamento de espírito seria visível principalmente na cidade. Quando retorna a Recife, em fins de dezembro de 1811, depois de uma estadia de pouco mais de seis meses na Inglaterra, ainda assim Koster pôde notar

(...) uma modificação considerável no aspecto do Recife e de seus habitantes, embora minha ausência fosse de curta duração. Várias casas tinham sido reparadas e as rótulas, sombrias e pesadas, foram substituidas pelas janelas, com vidros e balcões de ferro. Algumas famílias haviam chegado de Lisboa e três outras da Inglaterra. As senhoras das primeiras davam o exemplo, indo à missa a pé, em plena luz solar, e as damas inglesas tomavam por hábito passear, todas as tardes, por distração. ${ }^{74}$

\footnotetext{
73 Ibidem, p.56, 59, 204-05.

${ }^{74}$ Ibidem, p.257; grifos nossos.
} 
Difícil precisar a correição das datas de Koster. Mais difícil ainda considerar que as mudanças tenham sido tão rápidas, principalmente observando-se que uma viagem entre Portsmouth e Rio de Janeiro, por volta de 1800, poderia durar de 55 a 80 dias, dependendo das condições climáticas, dos ventos e correntes de navegação. ${ }^{75}$ Contudo, é importante registrar as mudanças, os melhoramentos propiciados pela abertura dos portos e cidades como caminhos para o progresso, quer tal percepção tivesse se dado em fins de 1811, quer fosse fruto da memória dos anos seguintes vividos entre Recife e sua casa-grande.

Importante também demarcar a pedagogia dos sentidos, a educação pelo exemplo de normas civilizadas das famílias vindas da Europa. Assim, continuaria:

Esses melhoramentos, mesmo introduzidos e praticados por outras pessoas, foram adotados por algumas outras, que conservavam o receio de iniciá-los e pelos demais, por acharem agradáveis. As fazendas de seda e cetim, tornadas de uso normal para roupa nas festas e dias santos, foram logo vencidas pelas musselinas brancas e de cor e tecidos de algodão. Os homens que antigamente compareciam todos vestidos de preto, com fivelas de ouro e tricórnio, não faziam grande questão em substitui-los pelas calças de naniquim, meias-botas e chapéus redondos. Mesmo a sela, alta e pesada, estava menos usada, e apresentava feitio mais moderno. As cadeirinhas, em que as senhoras iam a igreja ou pagar visitas de suas relações, tinham forma mais elegante e os carregadores se vestiam mais ricamente. ${ }^{76}$

Como dito antes, a cidade era o espaço dessa educação, do instruir-se na polidez de uma sociabilidade burguesa já em formação. Conforme observou a historiadora Izabel Marson, Koster movia-se no registro de uma "prática pedagógica reformista e reeducadora pacífica" que pudesse levar à superação dos atavismos e do atraso intrínseco ao "antigo regime", expresso na estrutura social e econômica do mundo rural, da casa-grande..$^{77}$ Registro que implicava, também, no recorte de exemplos para corroborar a argumentação de Travels in Braz̧il sobre a caracterização, e.g., do lugar da mulher em meio à sociabilidade do autoritarismo, da repressão e da indolência, mesmo que isso contradissesse outras experiências testemunhadas pelo

\footnotetext{
75 Luciana Martins, O Rio de Janeiro dos viajantes: o olhar britânico (1800-1850), 2001, p.70.

${ }^{76}$ H. Koster, op. cit., p.257-258.

77 Izabel A. Marson, O império da "conciliação": politica e método em Joaquim Nabuco - a tessitura da revolução e da escravidão, 2000, p.98.
} 
próprio autor. A ênfase na mulher confinada servia assim à "construção de um determinado conceito de feudalismo, de sociedade semi-civilizada e feudal". ${ }^{78}$

O progresso material da cidade era fundamental, depreende-se da leitura de Koster, para a superação do atraso derivado dessa estrutura social.

Numerosas casas de campo haviam sido construídas. As terras próximas ao Recife subiam de preço. O comércio de tijolos estava convenientemente lucrativo. Os trabalhadores eram procurados, e, sem falar noutras partes, os trechos situados entre os povoados de Poço de Panela e Monteiro, na extensão de 1 milha, que em 1810 era coberto de matagal, tinham sido limpos. As residências eram edificadas e tendo jardins próximos. A grande igreja do Corpo Santo, situada na parte da vila denominada Recife, estava agora terminada, e projetavam vários embelezamentos. A época dos melhoramentos chegara, e homens que tinham passado muitos anos sem pensar na menor transformação tanto do interior quanto no exterior de sua casa, estavam agora o pintando e envidraçando as fachadas, mobiliando o interior, modernizando eles mesmos, suas familias e suas moradas. ${ }^{79}$

Koster ajudaria, ao lado de outros viajantes, a construir maneiras de olhar e enquadrar a paisagem brasileira - da paisagem construída das vilas e cidades, sobremaneira, marcada pelos sons, pelos cheiros, pelas cores, pelos rituais religiosos e festas mundanas, cuja separação nem sempre era clara, pela população em movimento, miscigenada, negra, escrava. Como se disse antes, essa imagem não é única, mas tem muitos temas que se sobrepõem, a exemplo dos da reclusão das mulheres e da indolência.

Curiosamente, como já observou, o tema da indolência nos espaços urbanos dava-se concomitante ao registro iconográfico e literário das inúmeras atividades laborais dos escravos de ganho, dos pequenos comerciantes, artesãos e serviçais, numa azáfama sem fim que feria os olhos, os narizes e os ouvidos dos viajantes recém-chegados. Azáfama da qual faziam parte as mulheres, com seus tabuleiros de

\footnotetext{
${ }^{78}$ Idem, Imagens da condição feminina em "Travels in Brasil" de Henry Koster, Cadernos Pagu, 1995, p.231; sobre a leitura de Koster sobre o "estado feudal do senhor de engenho", cf. H. Koater, op. cit., cap. XI, p.294-299.

${ }^{79}$ H. Koster, op. cit., p.258; grifos nossos.
} 
doces, quitutes, com a leitura de mãos, rezas, balaios de roupa etc., mas mulheres que não eram brancas. ${ }^{80}$

Esses elementos participam da escrita de Koster, como pôde ser observado. Contudo, a eles não se limitou. Ao pensar o progresso do país que o acolhera, Koster iria pouco a pouco estruturando uma narrativa que apontaria a necessidade de a cidade tornar-se preponderante sobre o ambiente rural. Do mundo da casa-grande, que viveu como viajante e, depois, como residente, senhor de engenho, não se podia esperar o caminho dos melhoramentos. Ao contrário, ele podia fazer regredir inclusive um homem educado nos centros civilizados.

Assim, não é á toa que a paisagem urbana, diversa, fragmentada, se sobrepõem no texto de Koster, principalmente a paisagem em transformação de Recife. Transformação que tomaria ainda muito mais tempo do que deixaria entrever certo otimismo do autor com a abertura dos portos e com a maior circulação de mercadorias e hábitos progressistas. Essa sobreposição da paisagem material, que marca o relato de Koster, ajuda a entender o interesse pelo texto, dentre outros, em meio às discussões sobre os significados da formação do Brasil. Como diria Gilberto Freyre, em Ingleses no Brasil

Se Darwin aqui só se agradou dos recifes e das árvores, detestando os homens e o Recife que conheceu e fechando-se a toda convivência com a natureza humana do Brasil, Burton, Koster, Walsh foi no que se especializaram: nessa convivência com a natureza humana do Brasil e com suas particularidades. Nos descobrimentos não de novas espécies de peixes ou de plantas, mas de novos aspectos da natureza humana. ${ }^{81}$

A ênfase na paisagem material se inscreveria no horizonte das preocupações da intelectualidade brasileira que começaria a pensar o próprio país, seu passado, suas possibilidades de transformação e de construir-se como civilização ao longo do século XIX. Para tanto, deixar de lado aquela imagem de paisagem-só-natureza era fundamental. Uma passagem de Debret, em sua "Viagem Pitoresca e Histórica ao Brasil”, é exemplar. Encarregado de pintar um pano de boca de cena para teatro que

\footnotetext{
80 Amílcar Torrão Filho, $A$ arquitetura da alteridade: a cidade luso-brasileira na literatura de viagem (17831845), 2008, p.242-244.

${ }^{81}$ G. Freyre, Ingleses no Brasil: aspectos da influência britânica sobre a vida, a paisagem e a cultura do Brasil, 1977 [1948], p.13.
} 
representasse a fidelidade do povo ao governo imperial, assim o fez e apresentou o resultado ao então primeiro-ministro José Bonifácio, que o aprovou. "Pediu-me apenas que substituísse as palmeiras naturais por um motivo de arquitetura regular a fim de não haver nenhuma idéia de estado selvagem. Coloquei então o trono sob uma cúpula sustentada por cariátides douradas". ${ }^{82}$ Por vezes, essa preocupação adquiria tom de lamento, como o faria Joaquim Manuel de Macedo na década de 1860, em seus passeios pela cidade do Rio de Janeiro:

Sem teatros, sem galerias de belas-artes, sem parques, sem monumentos, sem riquezas artísticas que ocupem por momentos a atenção dos estrangeiros ilustres que chegam à nossa capital, nós (...) apelamos para os tesouros da nossa grandiosa natureza, e envergonhados da miséria das obras dos homens, (...) procuramos dirigir os passos dos nossos hóspedes para os arrabaldes da cidade. ${ }^{83}$

Outras vezes, tornava-se programa, como exposto no "prospecto" do jornal Illustração Brasileira, editado pelos irmãos Fleuiss ${ }^{84}$ :

Geralmente esta terra é admirada fora pela magnificência assombrosa da Natureza; uma paisagem com um selvagem no primeiro plano é ainda o emblema do Império, aos olhos do estrangeiro. Certamente daremos algumas dessas páginas de eterna beleza que as margens dos grandes rios e os sertões oferecem à admiração do homem civilizado; mas ao lado dela gravaremos outras que atestem o progresso e a civilização do país: os edifícios públicos, cidades notáveis, portos, obras hidráulicas, caminhos de ferro, fábricas, estabelecimentos e vasos de guerra, e tudo o mais que apresente aos olhos da Europa a colaboração do homem com a natureza. 85

De certo modo, Koster inscreve uma chave de leitura: é a paisagem material que interessa, mas não a paisagem da chegada. É a paisagem da cidade em transformação - que apontava um horizonte de possibilidades. Mais de um século

\footnotetext{
82 Apud F. Sussekind, O Brasil não é longe daqui: o narrador, a viagem, 1990, p.38.

${ }^{83}$ J. Manuel de Macedo, Um passeio pela cidade do Rio de Janeiro, v. 1, 2004 [1862], p.142, trecho sobre "O passeio público".

${ }^{84}$ A Illustração Brasileira sucedeu o periódico Semana Illustrada, mantida pelos irmãos e pelo pintor Carlos Linde entre 1860 e 1876; era um projeto mais ambicioso, com projeto gráfico esmerado e redatores como Machado de Assis, mas que malogrou financeiramente, cf. Lucia Guimarães, Henrique Fleiüss: vida e obra de um artista prussiano na Corte (1859-1882), v.8, n.12, 2006.

${ }^{85}$ [editores], Prospecto e Introducção, Illustração Brasileira, Rio de Janeiro, n.01, vol. I, 1 jul. 1876.
} 
depois, um memorialista pernambucano lembraria, baseado em Koster e outros viajantes:

Façamos uma asserção: na primeira metade do século passado $a$ rua pertencia aos negros. (...). A célebre rua da Cruz era um Valongo. E não se dava um passo por aí fora sem se ouvir, no ar, o grito estridente das vendedeiras de canjica, que se misturava ao reclamo característico das mercadoras de angu. Assim observaram Koster, Tollenare, Maria Graham e outros viajantes.

\section{$[\ldots]$.}

Nenhum outro teatro exibiu melhor suas aflicões que as nossas ruas. A atroada dos mercados elevava após si os olhos espantados dos estrangeiros. E, envolto em tangas, coberto de pústulas e tatuagens esquisitas, a mastigar roletes de cana e a espojar-se nas valetas empestadas, o negro atraía a comiseração dos passantes e representava esta cena trágica e desigual da escravatura, que era 'la révélation d'un monde inconnu', como dizia F. Denis. ${ }^{86}$

${ }^{86}$ Estevão Pinto, Pernambuco no século XIX, 1922, p. 33, 99. 
CAPÍTULO 2

\section{AS CIDADES ESTREITAS E SUJAS}

esforços para constituição de uma (nova) ordem urbana 
Além da crítica moral, que sempre marcou as reflexões sobre os aglomerados urbanos desde a Antiguidade, as considerações sobre o corpo físico da cidade ganharam novo vulto no início do século XIX, decorrentes, por um lado, da explosão demográfica e da diversificação dos problemas sociais e econômicos nas cidades do Velho Mundo, e, por outro, do incremento da circulação de pessoas e cousas (e, consequentemente, dos males epidêmicos) entre os portos de todos os continentes. ${ }^{1}$ Isso impôs a necessidade de criação de um aparato técnico de descrição, enquadramento e ação que, ademais, seria uma das bases formativas da disciplina moderna do urbanismo. ${ }^{2}$

Nesse aparato, o saber médico logo assumiria papel central. Uma das razões para essa centralidade encontra-se na longa tradição na qual se insere - de relacionar a saúde do indivíduo à saúde do meio - e que remonta, como é consabido, aos ensinamentos hipocráticos. Entretanto, essa tradição não se construiu como mero acúmulo ou continuação. Houve cortes epistemológicos que levariam a viravoltas decisivas na constituição do saber médico moderno e, consequentemente, na definição de determinadas maneiras de ler os espaços da cidade e do território. ${ }^{3}$

\footnotetext{
${ }^{1}$ A bibliografia é vastíssima sobre o impacto da chamada primeira revolução industrial para as cidades ao longo do século XIX, revelando problemas até então inauditos ou de escala desconhecida, cujas expressões não se limitam ao campo econômico e, sim, se estendem às dimensões culturais, sociais, políticas, etc., como o demonstra um dos trabalhos mais recentes de D. Harvey, Paris, capital of modernity, 2006. No Brasil, há um livro ainda de grande relevância: M. Stella Bresciani, Londres e Paris no século XIX: o espetáculo da pobreza, 1982.

2 D. Calabi, Storia dell'urbanistica europea, 2000, e F. Choay, A regra e o modelo, 1985.

${ }^{3}$ Não interessa a esse capítulo reconstruir a história desse saber médico mas, mesmo assim, anote-se alguns dados fundamentais para a formação da epistemologia médica moderna: a sistematização dos estudos de anatomia a partir do Renascimento, a superação da teoria dos humores corporais e a descrição do sistema circulatório do corpo humano, no século XVII, por Harvey, e, mais decisivo para os interesses desta pesquisa, a emergência do paradigma bacteriológico no final do século XIX, após declínio polêmico das teorias miasmáticas. Nesse sentido, as pesquisas de G. Rosen foram fundamentais (cf. e.g. Da polícia médica à medicina social: ensaios sobre a história da assistência médica, 1980) e subsidiaram outros estudos, como os de M. Foucault sobre o nascimento da clínica.
} 
O longo século XIX assistiria a derrocada das teorias miasmáticas em prol da episteme da biologia moderna, dos estudos sobre vírus, bactérias, infecções. De cambulhada, pôs-se em xeque os pressupostos da leitura mesológica e das condições sociais (que se imiscuíam às leituras dos miasmas) para a proliferação de epidemias e a eclosão de endemias. Movimento que não se deu de forma pacífica. O conjunto de polêmicas entre diversos saberes e as disputas por espaços institucionais (que garantiriam mais validade e possibilidade de emitir enunciados, pareceres, relatórios, etc.) é significativo a esse respeito e foi amplamente discutido.

Ainda assim, percebe-se a continuidade dos esforços de diversos profissionais do saber médico em diagnosticar os males das cidades, em espacializar suas endemias e epidemias, em construir um quadro analítico das condições de salubridade baseada extensivamente na compreensão do meio urbano e natural. Esses esforços iriam aparecer não apenas na forma de relatórios e memórias vinculadas mais estritamente aos órgãos de saúde pública que seriam organizados ao longo desse período, mas também por meio das chamadas topografias e geografias médicas, que continuariam a ser produzidas ainda no início do século XX.

A emergência do papel social dos engenheiros na esfera dos debates técnicos sobre os processos de modernização, arrogando condições, formação e legitimidade para propor e levar a cabo as soluções necessárias, implicaria também na assunção da tarefa de "diagnosticar", de esquadrinhar, de ler as cidades e o território de uma nação em formação. Passo decisivo para a configuração da matriz sanitarista - grosso modo, definida como a tecnicalização dos pressupostos higienistas, a construção de um aparato técnico, material, para tornar o corpo da cidade saudável.

Essa confluência de interesses e olhares que derivam de preocupações comuns, ainda que marcadas por especificidades - delimitemos por ora entre leituras "higienistas" e leituras "sanitaristas" ou entre o "mundo da higiene" e o "mundo sanitário" -, constituiu um corpus de leituras sobre as cidades que permitem entrever a formação de representações, a mobilização de lugares-comuns, os fundoscomuns que subsidiam interpretações.

\footnotetext{
4 Para usarmos expressão cara ao prof. Philip Gunn, A ascensão dos engenheiros e seus diálogos e confrontos com os médicos no urbanismo sanitário em São Paulo, in Anais do VII SHCU, 2002.
} 
Interessa assim, ainda que de forma episódica, investigar como as cidades foram lidas, e enfrentadas como problema técnico-científico, por essa matriz do pensamento. Ao cabo de mais de um século, não seria estranho encontrar uma afirmação como a de Gilberto Freyre, em Casa-Grande \& Senæala, para quem a "influência modificadora do homem", como se revelaria nas "sucessivas vitórias (...) sobre as doenças tropicais" empreendidas pela "higiene ou pela engenharia sanitária", foi crucial para superar a influência decisiva do clima - lido como obstáculo ao processo de colonização e, portanto, de civilização nos trópicos. ${ }^{5}$

Há aí uma chave de leitura que, defende-se como hipótese, seria central nas leituras sobre a cidade colonial no Brasil, a dizer: a crítica à morfologia das cidades coloniais foi fortemente derivada do viés inicialmente higienista e, em conseqüência, que a superação dessa morfologia foi tomada como metonímia da superação dos obstáculos à modernização do país.

Entretanto, não se pode deixar de mencionar que a leitura positiva do empreendimento colonizador português nos trópicos, feita por Gilberto Freyre ainda nos anos 1920, levaria ao elogio dessa herança expressa na paisagem urbana, sobretudo de Recife e Olinda. Tal leitura subsidiou, como se sabe, a polêmica contra as reformas modernizadoras do governo Sérgio Loreto. ${ }^{6}$ Essa ambigüidade marca, ainda que com outras especificidades, o discurso de Ricardo Severo pela preservação do caráter da cidade colonial, embora criticasse, com viés que ecoa claramente as diatribes higienistas, a implantação secular em lotes estreitos e profundos, que não permitia a iluminação e ventilação diretas; ${ }^{7}$ ou mesmo a não defesa de Câmara Cascudo do espaço tradicional da cidade de Natal (na verdade, até saudaria as propostas e ações reformadoras do final dos anos 1920) ao mesmo tempo em que

\footnotetext{
${ }^{5}$ G. Freyre, Casa-grande \& Senzala, 2006 [1933], p.75-76.

${ }^{6}$ José Lira, Mocambo e cidade: regionalismo na arquitetura e ordenação do espaço habitado, 1996, p.310-333; Fernando D. Moreira, A construção de uma cidade moderna: Recife (1909-1926), 1994; Joel Outtes, O Recife: gênese do urbanismo (1927-1943), 1997.

${ }^{7}$ Cf. Joana Mello, Ricardo Severo: da arqueologia portuguesa à arquitetura brasileira, 2007, p.178. Esses temas serão retomados, em parte, no capítulo 4 e nas considerações finais desta tese; mesmo assim, registrese desde logo que certa imprecisão e mesmo ambigüidade marca a composição de Casa-Grande \& Senzala, como já o apontou Ricardo Benzaquen: a permanência de um vocabulário e mesmo de estratégias de leitura eivadas de certa "lógica racial" de corte neolamarckiano não obsta a dimensão culturalista do livro; outrossim, a acusação de que Freyre edulcorou o passado colonial brasileiro ou mesmo as relações escravagistas viceja nessa imprecisão, cf. Guerra e Pą: casa-grande \& senzala e a obra de Gilberto Freyre nos anos 30, 2005, em especial p.25-39.
} 
valorizaria cada vez mais várias práticas e usos populares que tinham esse mesmo espaço como suporte. ${ }^{8}$

\section{1 higiene para as cidades}

O primeiro texto médico publicado no Brasil surgiu no contexto de abertura dos portos e da vinda da família real portuguesa para o Brasil. O opúsculo do médico da Real Câmara, Manoel Vieira da Silva, ${ }^{9}$ fez parte dos esforços, junto com a criação da Imprensa Régia, que o imprimiu, das escolas médico-cirúrgicas em Salvador e no Rio de Janeiro e de outras instituições, para estabelecer uma estrutura que permitisse combater o que se acreditava ser a ação deletéria dos trópicos sobre o europeu e, assim, gerar condições para a estadia da Corte no Brasil.

Publicado ainda em 1808, as "Reflexões" de Vieira Silva buscavam discutir os meios para remover ou, pelo menos, reduzir as causas das moléstias que grassavam na Colônia e, em especial, em sua capital. O texto, curto, constitui uma suma das preocupações higienistas então em voga, que se revela na maneira de ler o território da cidade; ao mesmo tempo, a síntese e brevidade do texto deixa perceber um certo caráter de urgência - acreditando na possibilidade de executar os pontos principais do que seria um programa higienista para as cidades. Há de se observar que, diante das inúmeras dificuldades para levar a cabo tal programa, esse caráter de urgência continuaria a marcar, cada vez mais, os muitos relatos médicos e o conjunto crescente de reflexões sobre a cidade brasileira ao longo do século XIX.

\footnotetext{
${ }^{8}$ Cf. A. Ferreira e G. Dantas, "Em nome da cidade": modernização, história e cultura urbana em Câmara Cascudo, in Eduardo Kingman (org), História social urbana: espacios y flujos, 2009.

${ }_{9}$ Vieira da Silva formou-se médico pela Universidade de Coimbra; fez parte do conselho de D. João VI, que o condecorou Barão de Alvaiazere, Comendador e Physico Mor do Reino (cf. M. Scliar, Introdução, in $A$ saúde pública no Rio de Dom João, 2008, p.16).
} 
Além da urgência, várias tópicas se tornariam correntes, ademais. O início da descrição médico-topográfica de Vieira Silva é exemplar: “A cidade do Rio de Janeiro tem o seu assento sobre uma planície pouco superior ao nível do mar, rodeada de montanhas mais e menos elevadas, deixando entre si canais, por onde se fazem sentir em toda a cidade os ventos reinantes; ao que parece obstar uma delas, chamada Morro do Castelo". ${ }^{10}$

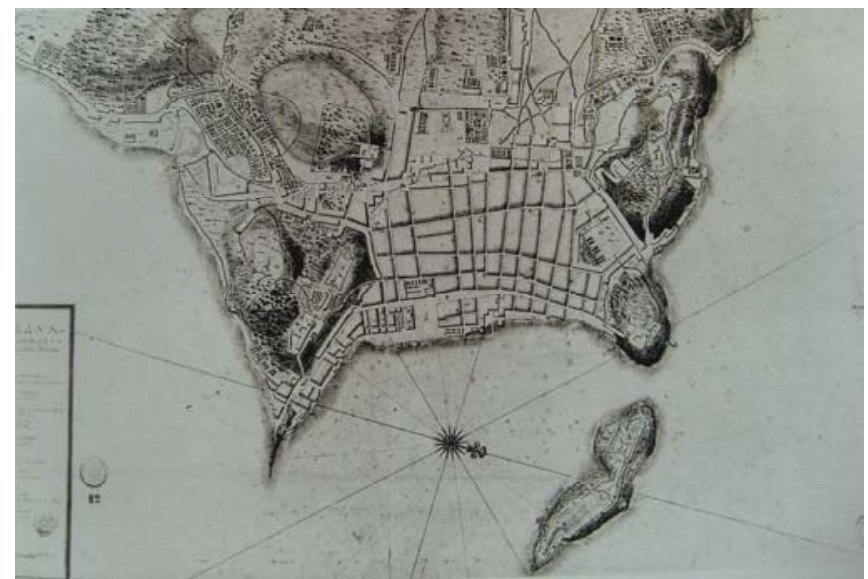

Figura 2.01: A. Vaz Figueira, Carta topográfica, São Sebastião do Rio de Janeiro, 1750.

Fonte: V. Andreatta, 2006, p.25.

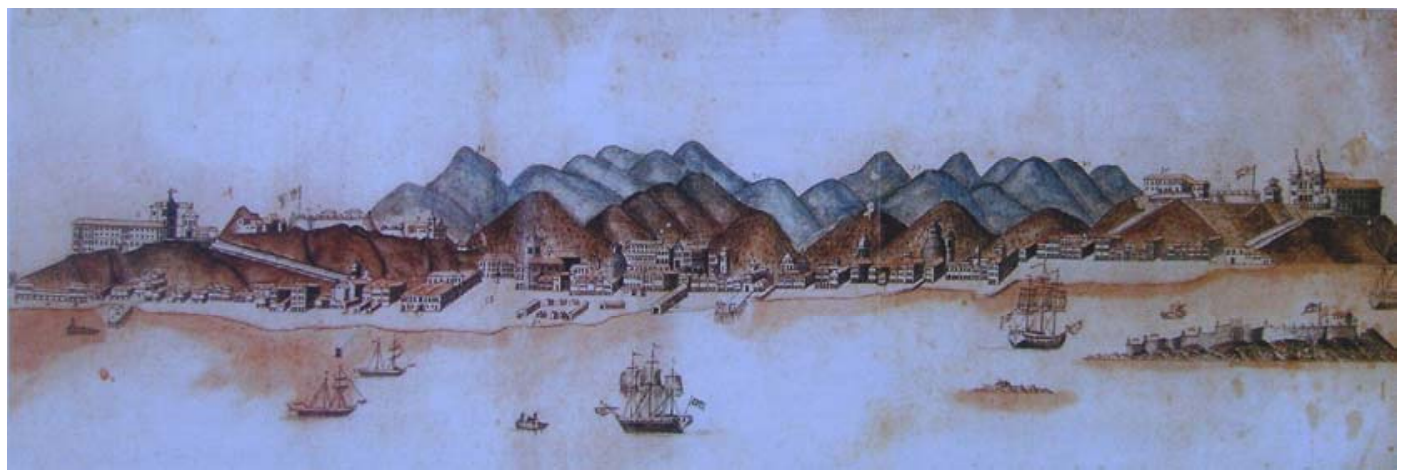

Figura 2.02: Prospecto da cidade do Rio de Janeiro, 1775, publicado em Notícias Soteropolitanas, 1803; com o Morro do Castelo à esquerda.

Fonte: V. Andreatta, 2006, p.51.

Fazer circular os ventos era essencial para o paradigma médico de então e, em especial, para as formulações baseados na teoria miasmática. Daí o physico-mor de D. João VI concordar, embora com ressalvas, com uma avaliação que, ao que tudo

10 M. Vieira da Silva, Reflexões sobre alguns dos meios propostos por mais conducentes para melhorar o clima da cidade do Rio de Janeiro [1808], in A saúde pública no Rio de Dom João, 2008, p. 69 70 . 
indica, parecia ser comum: "O Morro do Castelo será tão prejudicial à cidade como até agora se tem suposto! Deverá entrar no plano da polícia do Rio de Janeiro a sua demolição?". A questão era se, de fato, essa ação seria suficiente. Afinal, além dos onerosos custos para levar a termo a sua demolição, Vieira Silva avaliava que, a partir de algumas considerações sobre a mecânica dos fluidos, a área afetada pelo Morro era pequena:

(...) o morro [do Castelo] só poderia embaraçar a livre corrente do ar naquela pequena parte da cidade, que lhe fica muito próxima; porque as colunas de ar, que passam pelo ápice da montanha, e as laterais, não encontrando resistência, caminham com toda a velocidade com que vem impelidas; as que encontram resistência no morro aumentam por outro lado a força das primeiras em razão daquela, que as partículas refletidas sobre a montanha são obrigadas a comunicar às laterais. (...) podemos logo afirmar com toda a certeza que, ainda sendo os ventos muito brandos, deve haver um movimento insensível nas colunas do ar, que estão sobre as casas unidas ao morro. Chegam a confessar essa verdade os habitantes das ruas da Cadeia e de São José, pelo incômodo, que ali recebem, quando reinam ventos fortes, ainda os que sopram diretamente da Barra. ${ }^{11}$

Na verdade, na continuação da argumentação, Vieira Silva diria, mais ainda, que as formações montanhosas são fundamentais para a "ordem da grande economia da natureza", servindo para fins que não cabia ao homem perturbar - segundo as formulações da época, emanações elétricas, reservatório das águas e corpos minerais, estabelecimento de ordem de atração, como em outros lugares do mundo. Assim, ao invés da demolição do morro do castelo e de diversos outros que pontuavam a paisagem conhecida pelos marinheiros e práticos, Vieira Silva apontaria que seria mais apropriada a expansão da cidade longitudinalmente, ao longo das bordas do mar, e não na latitude, ocupando os morros, as quintas, os arrabaldes. "A cidade do Rio de Janeiro não chega a ter um oitavo de légua na sua maior extensão; e se intentassem distendê-la, como de necessidade há de acontecer, quantos edifícios não ficariam ao abrigo dos montes, como acontece em Lisboa? E, seguindo o sistema de demolir, quantas as dificuldades, e quais seriam as conseqüências?”12

\footnotetext{
${ }^{11}$ M. Vieira da Silva, op. cit., p.71.

12 Ibidem, p.71-72.
} 
O texto breve de Vieira Silva não permite muitas especulações para quem o lê a partir de hoje. Ainda assim, além dos aspectos mais visíveis e de claras implicações (derivadas da teoria miasmática, e.g.) para a leitura do espaço e da paisagem das cidades luso-brasileiras, como se discutirá adiante, percebe-se a presença de alguns elementos que revelam a circulação de temas diversos, de substratos culturais antigos, assim como de novas concepções teóricas. Por exemplo, essa - lendo a posteriori inusitada defesa do Morro do Castelo pelo médico parece ressoar a então nova concepção científica de paisagem de Alexander von Humboldt, que cruza o rigor exaustivo da descrição científica da natureza com as possibilidades da fruição estética, de percepção da conexão elementar do ser com o todo, da unidade da natureza, questionando as maneiras de interação das forças naturais e as relações entre o ambiente geográfico e a vida humana; e reconhecendo a existência de forças vitais que confeririam à natureza uma dinâmica que, em muito, escapava ao domínio humano. ${ }^{13}$

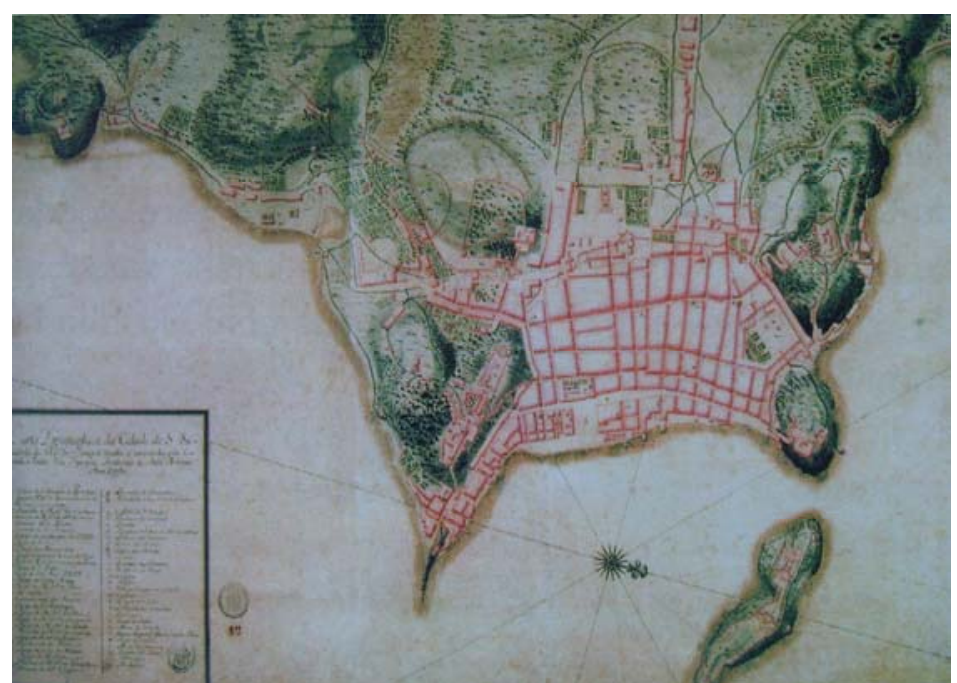

Figura 2.03: J. Massé, São Sebastião do Rio de Janeiro e suas fortificações, 1713

Fonte: V. Andreatta, 2006, p.25.

Se, como pretendia demonstrar, nem o Morro do Castelo e nem mesmo a "atmosfera" da cidade, considerados isoladamente, constituíam sérios entraves à saúde pública, Vieira Silva voltar-se-ia para as verdadeiras "grandes causas" - todas,

13 Ana Belluzzo, O Brasil dos viajantes, vol.II, p.21-22.; L. Murari, Tudo o mais é paisagem: representações da natureza na cultura brasileira, 2002, p.99-100. 
obras dos homens e, ao assim ser, poderiam ser extintas. Mais do que o entrave à circulação dos ventos, preocupava em demasia a estagnação das águas: "é logo para lastimar que o homem observador entrando nesta cidade a descubra por todos os lados cercada de lugares pantanosos". ${ }^{14}$ Era a imprecação característica das preocupações com os miasmas - a exalação de pestíferos gases oriundos da putrefação de matéria orgânica, vegetal ou animal, sob forte calor. Desta forma,

É por conseqüência da boa polícia o aterrar todos os lugares pantanosos, o encanar as águas para aquelas valas que se julgarem deficientes ao seu despejo, e que devem participar das alternativas da maré; o determinar o lugar em que se devem edificar as casas, a altura das portas à estrada, para que os particulares concorram com o Estado ao aterro das novas ruas, sem que por isso sofram ao depois as suas propriedades; demarcar a direção e largura das ruas; e tudo o mais que no meio de semelhantes cuidados se julgar necessário para extinguir uma causa tão oposta à nossa boa existência. ${ }^{15}$

Desses semelhantes cuidados trataria ainda o médico Vieira Silva, a dizer, a condenação da prática de inumação em solo sagrado, em torno das igrejas; a necessidade de construção de hospital em local plano - para permitir que o passeio reparador aos convalescentes não seja prejudicado pelos caminhos cheios de "desigualdades"; organização de lazaretos nas imediações dos portos para receber, principalmente, os "pretos", de forma regular, e as vítimas ou suspeitas de infectados por alguma moléstia epidêmica; o controle da entrada e comercialização dos diversos gêneros alimentícios e, com especial atenção, a mudança de lugar e a regulamentação do matadouro; ademais, considerava imperativo o controle sobre o próprio ofício da medicina, sendo necessário restringir a concessão de cartas aos práticos (sangradores, barbeiros), assim como, a venda imprevidente de remédios, que se dava até em lojas de ferragem. ${ }^{16}$

Ao leitor familiarizado com a historiografia que discute a relação entre higiene, sanitarismo, cidade e território, a publicação dessas Reflexões de Vieira Silva soa quase como um programa inicial das leituras e ações de cunho higienista para as cidades brasileiras nas décadas seguintes - principalmente, a partir da década de 1850

\footnotetext{
14 M. Vieira da Silva, op. cit., p.72.

15 Ibidem, p.73; grifos nossos.

16 Ibidem, p.73-82.
} 
quando a supressão praticamente definitiva do tráfico escravagista levou ao direcionamento dos investimentos privados para obras de melhoramentos, construção de ferrovias, estabelecimentos de serviços públicos, etc. Afinal, qual vila ou cidade, quer de maior ou menor importância na rede urbana, não passaria por um debate e por embates em torno de vários ou mesmo de todos esses "semelhantes cuidados"? ${ }^{17}$

As Reflexões de Vieira Silva configurariam, portanto, um texto instaurador (no sentido que dá à expressão a filósofa Françoise Choay, i.e., como um texto que delimitaria com clareza os elementos de um corpus teórico, da estrutura fundamental de um determinado paradigma que se articula) $?^{18} \mathrm{O}$ texto não tem substância para tanto e compila uma concisa visão geral sobre o problema da salubridade da cidade luso-brasileira. Assim, parece ser mais apropriado considerá-las como um marco significativo, um documento que ajuda a iluminar articulações e considerações que iriam ganhar, cada vez mais, significância, espaço institucional e possibilidades de gerir e transformar em ações as formulações teóricas, ainda que limitadas no mais das vezes.

Afinal, sabe-se, e.g., que em 1798 os membros do senado da câmara do Rio de Janeiro prepararam uma enquete dirigida aos médicos da capital, argüindo sobre as causas das sucessivas epidemias que assolavam a cidade. A pergunta trazia em si uma tese explícita: o clima quente e úmido seria ocasionado pelo impedimento que os morros fazem aos ventos terrais ou matutinos e às virações vespertinas (atravancados esses últimos pelos morros do Castelo, Santo Antonio e Fernando Dias, e os primeiros pelos morros que correm de São Bento até São Diogo). Os médicos confirmariam as inquietações dos edis, acrescentando ainda as causas oriundas da desordem urbana - a falta de canalizações para esgoto e estagnação das águas pluviais, o acúmulo de lixo e imundície de ruas e praças -, além da arquitetura

\footnotetext{
17 Aqui também a bibliografia é vasta, com diversos estudos de caso divulgados e discutidos nas sessões dos Seminários de História da Cidade e do Urbanismo e das mesas de história urbana dos Encontros Nacionais da ANPUR, desde 1990, e assim citamos alguns (que abarcam também a segunda metade do século XIX), mas sem a pretensão de qualquer totalização: sobre Natal, cf. Angela Ferreira et al., Uma cidade sã e bela: a trajetória do saneamento de Natal. 1850-1969, 2008; sobre João Pessoa, cf. Maria Cecília Almeida, Espaços públicos em João Pessoa (1889-1940): formas, usos e nomes, 2006; sobre Campina Grande, cf. Marcus Queiroz, Quem te vê não te conhece mais: arquitetura e cidade de Campina Grande em transformação (1930-1950), 2008; sobre Recife, cf. Raimundo Arrais, O Pântano e o Riacho, 2004; sobre Campinas, cf. José Roberto Lapa, Cidade: os cantos e os antros, 1996.

18 F. Choay, A regra e o modelo, 1985, p.06-10.
} 
civil ordinária acanhada, de casas úmidas, pouco asseadas e ventiladas. A solução estaria, apontavam os médicos inquiridos, na preservação da cobertura vegetal, na limpeza regular das vias públicas e nas praças, no direcionamento do despejo dos esgotos fora da baía, no dessecamento de áreas alagadiças, no incentivo para a construção de casas mais altas e ventiladas, além da eliminação de alguns morros. ${ }^{19} \mathrm{O}$ físico-mór de então, Bernardino Antonio Gomes, enfatizara por sua vez os problemas derivados dos vícios e excessos, em especial os relacionados à prostituição. $^{20}$

Antes ainda, em célebre ensaio sobre as relações e as vantagens econômicas das colônias, em especial do Brasil, para Portugal, o bispo de Elvas, Azeredo Coutinho, que fizera carreira eclesiástica e administrativa em Pernambuco e, depois, na metrópole, argumentaria a favor do desmonte do Morro do Castelo. ${ }^{21}$ Interessa observar que, além do argumento baseado na leitura médica do território, Azeredo Coutinho procuraria localizar na história as condicionantes para entender o desenvolvimento que fez do Morro do Castelo o entrave principal para a salubridade do Rio de Janeiro.

A necessidade de defesa (das incursões indígenas) e de controle do território e da baía levou os primeiros povoadores a se estabelecerem no alto do morro escarpado. Em conseqüência, a ocupação da planície fez-se no sopé dessa área repleta de elevações - que logo cobrariam seu preço. Assim,

(...) tratando só de se aproveitarem da planície, [os povoadores] não advertiram que ficavam cercados de montes e principalmente do grande do Castelo, da parte da barra, donde entra o vento da viração todos os dias, como é freqüente nas terras entre os Trópicos, vindo por isso a ficar o local da cidade muito abafado: a falta de respiração, que em outro tempo não era tão sensível, por

${ }^{19}$ Cf. Carlos Sampaio, Memória histórica: obras da prefeitura do Rio de Janeiro, Lisboa, Lumen, p.09-16, apud C. Kessel, Tesouros do Morro do Castelo, 2008, p.31-34; e M. V. Silva, Naturalismo e biologização das cidades na constituição da idéia de meio ambiente urbano, 2005, p.76.

${ }^{20}$ G. Freyre, Sobrados e Mucambos, 2004 [1936], p.276.

21 A referência de Kessel (op. cit., p.34) levou-nos a consultar o livro de Azeredo Coutinho (a $2^{\mathrm{a}}$ edição, aumentada e corrigida pelo autor, publicada em 1816; a $1^{a}$ edição é de 1794). O "Ensaio" de Azeredo Coutinho é exemplar das posições de uma dos representantes mais influentes do reformismo ilustrado (da sociedade e das instituições, mas mantendo a monarquia, em clara perspectiva contrarevolucionária) em Portugal em fins do século XVIII, como discute Francisco Vaz, O pensamento económico do Bispo de Elvas, D. José Azeredo Coutinho, Revista Cultural de Marvão, 1998. Sobre o pensamento ilustrado luso-brasileiro na virada para o século XIX e, em especial, sobre as propostas de Azeredo Coutinho, cf. Fernando Novais, O reformismo ilustrado luso-brasileiro: alguns aspectos [1984], in Aproximações: estudos de história e historiografia, 2005, p.167-181. 
ser a Cidade mais pequena e mais arejada, hoje pela sua grandeza se tem feito bastante penosa. ${ }^{22}$

Azeredo Coutinho apontava claramente para um erro fundacional na escolha do sítio original. Entretanto, não era um erro exclusivo dos povoadores do que seria depois o Rio de Janeiro ou mesmo, de maneira geral, dos portugueses na ocupação do litoral do Brasil; ao contrário, as necessidades imperiosas explicavam essas imprevidências de muitas cidades antigas, para as quais o tempo e as circunstâncias permitiriam se aperfeiçoar e dar-se polidez. ${ }^{23}$ Erro que se fazia sentir claramente num momento de expansão da cidade. Importante era reconhecer que esses "males são remediáveis, sem que seja preciso esperar-se por um terremoto [como acontecera em Lisboa] (...), nem por um incêndio, nem por uma guerra devastadora. Uma só palavra do Soberano [e] aquela Cidade será a melhor do Mundo. A Natureza lhe tem dado tudo, a Arte é o que lhe falta". ${ }^{24}$

Para Azeredo Coutinho, a principal solução era, portanto, o desmonte do Morro do Castelo. Desmonte que, ao mesmo tempo, viabilizaria a construção da cidade com arte, uma nova cidade, que permitiria reduzir, paulatinamente, a "Cidade velha" a quintas e grandes praças, que tanta falta faziam:

O grande monte do Castelo, que serve de padrasto àquela Cidade e que lhe impede quase toda a viração do mar, tão necessária debaixo da Zona Tórrida, está sobre o mar pela parte da praia de S. Luzia, para onde pode ser lançado, fazendo-se encostar toda a terra desmontada ao longo da mesma praia, seguindo para a de Nossa Senhora da Glória, até se fosse possível chegar à Fortaleza do Villegagnon, e sobre todo o terreno, que ficasse do dito monte juntamente com o novo aterro, formado ao longo da praia, se poderia edificar uma cidadela nova, muito grande, e com todas as proporções que se quisesse, dispondo as ruas de sorte que recebessem a viração da barra, dando-se ao terreno novamente formado toda a altura necessária para o escoamento das águas (...). 25

\footnotetext{
22 Azeredo Coutinho, Ensaio economico sobre o commercio de Portugal e suas colonias, 1816, p.06-07.

${ }^{23}$ Ibidem, p.05; a frase é: “(...) teve na fundação e edificação o defeito que sempre tem tido todas as Cidades antigas, assim como também as Nações, que só o tempo e as circunstâncias as vão polindo e aperfeiçoando (...)".

${ }^{24}$ Ibidem, p.07.

${ }^{25}$ Ibidem.
} 
Diante de tal benefício, auspiciava-se tanto mais ar quanto, consequentemente, mais salubridade para a cidade do Rio de Janeiro. O importante era afirmar a possibilidade de vida e civilização sob os trópicos. Para tanto, Azeredo Coutinho argumentaria claramente contra o "Sistema dos climas" de Montesquieu argumentação que encontraria eco na imprensa francesa e nas notas sobre a publicação de sua obra em inglês e que seria essencial para construir a defesa da reforma e renovação das relações econômicas, ainda sob o estatuto colonial, de Portugal com suas colônias. ${ }^{26}$

Assim, crê-se ser possível afirmar que há muitas leituras e substratos, diretos ou indiretos, que perpassam o texto de Vieira Silva ou mesmo os Prolegômenos de Domingos Peixoto, publicado em 1820 (que serão discutidos adiante), dentre muitos outros. Permanências do humorismo hipocrático, da teoria dos miasmas, das leituras que correlacionavam a integridade e o equilíbrio do corpo humano e as condições do ambiente, assim como dos procedimentos de investigação derivados das geografias e topografias médicas. Permanências que teriam claras implicações na configuração do que aqui se chama de matriz higienista (e, depois, sanitarista) na leitura das cidades no início do século XIX.

Permanências, ademais, que circulariam e adentrariam, inclusive, o século XX. Embora como resquício de um paradigma prestes a desaparecer, os miasmas, e.g., ainda precisaram ser "considerados", conforme relata a historiadora Marta de Almeida, como variável no conjunto de experiências conduzidas no Hospital de Isolamento de São Paulo, com o aval dos médicos Emílio Ribas e Adolpho Lutz e outros do Instituto Bacteriológico, para provar a condição do mosquito Stegomyia fasciata (hoje, Aedes aegypti) como vetor para a disseminação da febre amarela. ${ }^{27}$ Outrossim, as geografias e topografias médicas, que renovaram a leitura dos territórios a partir da expansão colonialista européia, seriam ainda reiteradamente realizadas nas primeiras décadas do século XX no Brasil: para Manaus, em 1916,

\footnotetext{
${ }^{26}$ Francisco Vaz, O pensamento económico do Bispo de Elvas, D. José Azeredo Coutinho, Revista Cultural de Marvão, 1998, p.314.

27 Para realizar a experiência, os voluntários “dormiram com lençóis e roupas manchados e infectados pelo sangue e o vômito de doentes, num quarto vedado para que não entrasse nenhum mosquito e com uma estufa para que o recinto permanecesse constantemente calorento, evitando assim a contraargumentação infeccionista de que a queda brusca de temperatura fosse capaz de destruir os 'miasmas' da febre amarela" (Marta de Almeida, Tempo de laboratórios, mosquitos e seres invisíveis: as experiências sobre a febre amarela em São Paulo, in Artes e oficios de curar no Brasil, p.136).
} 
Natal, em 1920, Joinville, em 1926, Ponta Nova-MG, em 1932 e a do estado do Ceará, em 1925. Apesar das imprecações de sabor oitocentista em vários desses textos - sabor que se revela também na estrutura dos trabalhos -, as leituras são claramente marcadas pelos novos estudos etiológicos e pela microbiologia. A preocupação com as águas paradas permanecia - não pela exalação de miasmas, mas, sim, pelo ambiente propício que criavam para a proliferação de larvas e mosquitos. ${ }^{28}$

Ao longo do século XIX, a cidade do Rio de Janeiro seria o principal objeto das reflexões construídas dentro dessa perspectiva. ${ }^{29}$ As razões são claras e bem estudadas. Capital da colônia desde o último quartel do século XVIII e cabeça do Reino de Portugal, Algarves e Brasil, com a vinda da Corte e, depois, cabeça do Império, a cidade do Rio de Janeiro demandou esforços crescentes e contínuos para transformar a antiga ordem colonial. Esforços que se deram, em maior ou menor articulação, em diversas cidades. Contudo, o Rio de Janeiro, pela sua condição na estrutura geopolítica e administrativa do Atlântico Sul, foi o "epicentro" do "processo de constituição de uma nova ordem urbana brasileira como uma das dimensões do novo processo civilizatório que experimenta o país a partir da urbanização das cidades". ${ }^{30}$

Há que se considerar que, no início do século XIX, ainda não estava posta em xeque, diretamente, o estatuto colonial das vilas e cidades no Brasil, mas se depreende como essa leitura já se insinuava e como ganharia corpo nas décadas seguintes. Vieira Silva, no intróito às suas Reflexões, aponta que a vinda da Corte permitiria estreitar o controle e a observâncias às leis, dado fundamental para a manutenção do equilíbrio do corpo físico e do tecido social do território - que não

${ }^{28}$ Cf. Angela Ferreira, Anna Rachel Eduardo e George Dantas, Saudáveis trópicos: cidade, higiene e ordem para a Nação em formação (Brasil, 1850-1930), in La integración del território en una idea de Estado. México y Brasil, 1821-1946, 2007.

${ }^{29}$ Como, e.g., no trabalho de Gustavus Horner, Medical topography of Brazil and Uruguay with incidental remarks, 1843, que dedica parte considerável à cidade do Rio de Janeiro (cf. em especial os capítulos II, V e VII); o do médico José Francisco X. Sigaud, Du climat et des maladies du Brésil ou statisque médicale de cet Empire, de 1844, o de Alphonse Rendu, Études topographiques, médicales et agronomiques sur le Brésil, de 1848, e de Francisco Araújo, Considerações geraes sobre a topografia phsico-medica da cidade do Rio de Janeiro, de 1852. O boletim da Sociedade de Geografia do Rio de Janeiro manteria séries estatísticas para composição da geografia médica da cidade no final do século XIX, cf. João Pires Farinha, Geographia medica: apontamentos sobre a mortalidade do Rio de Janeiro, tomo III, $2^{\circ}$ boletim, abr-jun 1887 , p.130-31; idem, tomo III, $3^{\circ}$ boletim, jul-set. 1887, p. 210-11; idem, tomo III, $4^{\circ}$ boletim, out-dez. 1887, p.312-13; a série continuaria a ser publicada em 1888 e 1889, pelo menos.

30 R. Pechman, Cidades estreitamente vigiadas: o detetive e o urbanista, 2002, p.39; Paulo Marins, Através da rótula, 2001, em especial os capítulos III, IV e VI. 
pudera ser observado antes devido à imensa distância oceânica a separar a vontade Real da vida cotidiana dos seus súditos d'além-mar. Contudo, apontaria o médico, chegou "a feliz época que os faz sair da desgraça que os rodeava e entrar na história das nações civilizadas". ${ }^{31}$

A cidade colonial não era ainda metonímia do atraso ou razão fundamental para explicar uma insalubridade atávica. Por óbvio, essas leituras derivam também da crítica à cidade medieval européia, às questões gerais sobre a insalubridade e a corrupção moral das cidades antigas, inchadas, misturadas socialmente, que vinha se processando, e.g., tanto na Inglaterra quanto na França na virada para o século XIX, exemplos consabidos na historiografia sobre o tema. ${ }^{32}$ A operação que construiria essa metonímia ainda seria elaborada, valendo-se também da crítica à cidade estreita e suja que se fez à revelia, formulava-se, de um poder central.

O texto do médico Domingos dos Guimarães Peixoto ${ }^{33}$ permite ilustrar como a negatividade vai se construindo, incorporando elementos peculiares, que diziam respeito às condições do sistema colonial e suas expressões na vida social urbana sobremaneira. Publicado em $1820,{ }^{34}$ apontava os caminhos e delineava a construção do "quadro topográfico médico" da cidade do Rio de Janeiro, embora reconhecesse a dificuldade de articular as múltiplas variáveis que o deveriam compor. Derivado da orientação empiricista de viés neo-hipocrático, os Prolegômenos utilizavam um protocolo de observações, como define o pesquisador Flavio Edler acerca da

\footnotetext{
${ }^{31}$ M. Vieira da Silva, op. cit., p.69.

32 No capítulo 1, já se apontou como parte dos valores e metros civilizacionais utilizados pelos viajantes derivavam das próprias leituras depreciativas (que apareciam em guias de viagens, e.g.) acerca das grandes capitais feitas por franceses (sobre Londres) e por ingleses (sobre Paris), principalmente sobre os subúrbios e sua sujidade assustadora, o amontoado amoral de pessoas, os vícios, etc. Cf. Amilcar Torrão Filho, A arquitetura da alteridade: a cidade luso-brasileira na literatura de viagem (1783-1845), 2008, p.261-64.

33 Peixoto, Barão de Igarassu, nasceu em Pernambuco, em 1790, e faleceu no Rio de Janeiro em 1846; formou-se pela Escola Médico-Cirúrgica do Rio de Janeiro e doutorou-se em Medicina pela Universidade de Paris, em 1830, com tese sobre o uso medicamentoso das plantas brasileiras; foi membro do conselho do Imperador, médico da Imperial Câmara, sócio da Real Academia de Medicina de Paris e de outras instituições e ordens, além de lente de fisiologia no Rio de Janeiro (Cf. M. Scliar, Introdução, in A saúde pública no Rio de Dom João, 2008, p.17, 20). Em 1820, Peixoto era Cirurgião da Câmara Real.

34 Domingos Peixoto, Aos sereníssimos Príncipes Reais do Reino Unido de Portugal e do Brasil e Algarves, os senhores D. Pedro de Alcântara e D. Carolina Josefa Leopoldina oferece, sem sinal de gratidão, amor, respeito e reconhecimento estes Prolegômenos, ditados pela obediência, que servirão às observações, que for dando das moléstias cirúrgicas do País, em cada trimestre [1820], in $A$ saúde pública no Rio de Dom João, 2008, p.84-118; doravante, aqui se fará referência ao livro como "Prolegômenos".
} 
literatura sobre as causas ambientais das doenças, que partia das circunstâncias mais gerais até atingir os elementos particulares de cada doente. ${ }^{35}$ Assim, Domingos Peixoto, ao buscar a síntese da sua concepção de saúde, afirmaria que

Um sem-número de causas morfíbicas e muito diversas nos podem afetar com maior ou menor prontidão, imprimindo em nossa organização um modo de existir muito diferente e análogo à sua ação: aqui se achando dispersas no seio da atmosfera, e em torno de nós - circunfusa; ali postas em contato com o nosso corpo - applicata; de uma parte introduzidas nos nossos órgãos - ingesta; de outra existindo dentro de nós mesmos, e dependem do desarranjo das evacuações, dos movimentos e das paixões excreta, gesta et percepta. 36

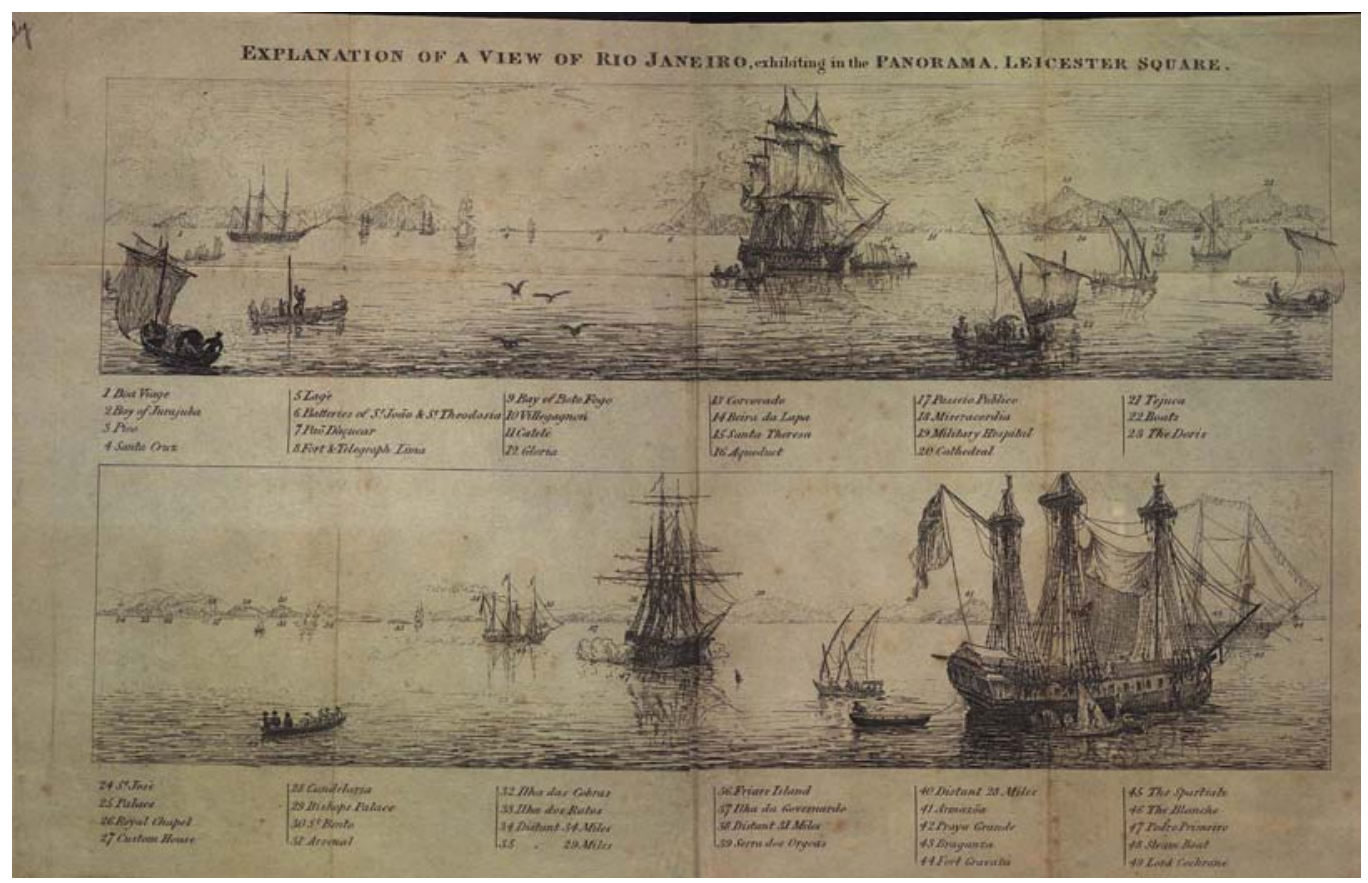

Figura 2.04: Robert Burford, Description of a view of the city of St. Sebastian and the Bay of Rio de Janeiro [panorama], 1824

Fonte: R. Burford, 1827.

Os termos expostos por Domingos Peixoto, além de desvelarem a clara filiação ao gênero das geografias e topografias médicas, que levaram a várias inovações no saber médico nos séculos XVIII e XIX - ainda que dentro dos paradigmas pré-pasteurianos -, permitem entender como seria construída a leitura das cidades (ainda) luso-brasileiras. Afinal, os circunfusa diziam respeito aos elementos da meteorologia, hidrologia, geologia, do clima e das habitações; os ingesta, aos

${ }^{35}$ F. Edler, De olho no Brasil: a geografia médica e a viagem de Alphonse Rendu, História, Ciências, Saúde - Manguinhos, 2001.

${ }^{36}$ Domingos Peixoto, Prolegômenos [1820], op. cit., p.88. 
alimentos e bebidas; os excreta, às excreções e banhos; os applicata, às vestimentas e cosméticos; os percepta, aos costumes, à sexualidade e higiene pessoal; e os gesta, aos movimentos habituais e às atividades profissionais. ${ }^{37}$

Daí emerge uma leitura que, de início, condenaria a cidade pelo seu elemento fundamental de identificação secular para a navegação. O perfil topográfico, "uma imensidade prodigiosa de serras empinadas e horrorosas", cuja descrição fora consolidada pela leva de viajantes desde o século XVI e que no início do XIX despertava sensações de sublime e de deleite pitoresco (como, e.g., na descrição de Robert Burford, em vista panorâmica de 1827), não resistia ao olhar perscrutador do médico:

\begin{abstract}
Esses elevados morros, parecendo-nos oferecer uma grande barreira à destruição do Rio, são todavia prejudiciais, não só porque obstam que os ventos circulem livremente no grande espaço compreendido entre si mesmos, mas porque servem de escoadores às copiosíssimas águas que recebem das chuvas, as quais em parte são recebidas em muitos e caudalosos rios que se dirigem ao braço de mar, entremetido em forma de baía; em parte alagam mais ou menos o terreno, o qual acumulado de mais a mais das águas que recebe das mesmas chuvas não as pode escoar livremente pela sua situação baixa e irregularidade de sua superfície; (...). ${ }^{38}$
\end{abstract}

As dificuldades de escoamento e a conseqüente estagnação, decomposição e evaporação das águas e do "ar atmosférico", constantemente denunciadas, tinham levado à proposta de um novo nivelamento das ruas e de remodelação das calçadas pelo Arquiteto da cidade (nomeado por D. João VI em 1808), o Capitão do Real Corpo de Engenheiros José Joaquim de Santa Anna, em sua "Memória sobre o enxugo geral desta cidade do Rio de Janeiro", distribuída em 1816. ${ }^{39}$ Problema persistente cujas causas Domingos Peixoto endossaria: as ruas e largos da região central, com pouca altura e mal calçadas, faziam com que a cidade fosse "toda ela pantanosa, as águas de chuvas que recebe, não podendo ter saída para o mar, por

\footnotetext{
${ }^{37}$ F. Edler, De olho no Brasil: a geografia médica e a viagem de Alphonse Rendu, História, Ciências, Saúde - Manguinhos, 2001, p.928.

38 Domingos Peixoto, Prolegômenos [1820], op. cit., p.97.

39 Este trabalho foi apresentado ao Príncipe Regente em 1811 e, após atualizações, novamente em 1815, cf. Ana Camargo e Rubens Moraes, Bibliografia da Impressão Régia do Rio de Janeiro, 1993, p.xxiii, $151-152$.
} 
falta de escoante, e de aquedutos suficientes, aí se demoram e são evaporadas pelo calor do sol". ${ }^{40}$

Os termos neo-hipocráticos conduziam a uma leitura severa da cidade. A longa citação que se segue é instrutiva e necessária para entender o uso das palavras, das maneiras de descrever e nomear os problemas:

A disposição dos edifícios é muito pouco favorável; o maior número deles são mal construídos e não tem a duplicada vantagem de uma habitação saudável, e de darem à cidade aquela vista linda e agradável que lisonjeie os seus habitantes; o seu pavimento estando quase ao nível do da cidade, e em alguns sendo ainda mais baixo está claro que tais habitações devem ser muito úmidas e sujeitas a serem banhadas pelas águas das chuvas, quando aturadas e fortes. As ruas, geralmente falando, são estreitas, e essa condição faz com que o giro dos ventos seja pouco favorecido e se sinta, in maximum, o calor do sol; não há aquele desafogo de que somos advertidos quando passamos por alguns lugares, que se devem antes reputar saídas da cidade, tais como a denominada rua larga de São Joaquim, a dos Ciganos, Lavradio, e Ajuda em certa distância. Segundo a sua direção, umas devem participar da viração, outras do terral; as primeiras encontram os dois morros do Castelo e de Santo Antônio, particularmente aquele, que lhes obstam mais ou menos essa circunstância tão vantajosa, quão saudável, por cujo motivo da irregularidade com que é distribuida a viração nas ruas correspondentes e mesmo da falta dela em alguns resulta que sentimos alternativamente impressões estranhas que nos incomodam sobremaneira; as segundas recebem princípios nocivos deletérios emanados das imundícies das praias e de certos lugares tocados pelo terral. ${ }^{41}$

Apesar dos esforços conduzidos após a chegada da Corte Portuguesa em prol da salubridade e, consequentemente, da instauração de padrões civilizados de vida social urbana, Domingos Peixoto reafirmava as "causas morbíficas" que ainda deixavam o Rio de Janeiro doentio e, mais ainda, o país, que pouco a pouco se libertava da condição de região malfazeja e inabitável. Havia muito a ser feito para tornar a nação viável e saudável - e, para tanto, era fundamental disseminar os preceitos da higiene pública. ${ }^{42}$

Mais uma vez, percebe-se o eco de leituras que revelam a persistência do determinismo geográfico, contudo numa perspectiva de reversibilidade (e não de

\footnotetext{
${ }^{40}$ Domingos Peixoto, Prolegômenos [1820], op. cit., p.99.

${ }^{41}$ Ibidem, p.99-100; grifos nossos.

${ }^{42}$ Ibidem, p. 107-108, 117.
} 
impossibilidade, como o faria, e.g., o jurista Cornelius de Pauw, em Recherches philosophiques sur les Américains, publicado em 1768) - a partir de uma ação decisiva que transformasse estruturas materiais e costumes atávicos. Entretanto, esse determinismo vinha sendo confutado desde meados do século XVIII, ao menos. Azeredo Coutinho argumentara contra o que considerava o erro do "sistema dos climas" de Montesquieu, como citado antes. Antes ainda, em 1759, o cronista Loreto Couto, ao visitar e descrever a vila de Recife, fixara a noção de locus amoenus para falar do clima da região, aprazível, sem grande amplitude térmica - "não há verão que aflija; nem inverno que moleste". ${ }^{43}$ De fato, a noção de país de clima aprazível, infenso a epidemias e endemias de alcance significativo, manter-se-ia até meados do século XIX, quando as devastadoras epidemias de febre amarela (1849-50) e do cólera (1855-56) puseram em xeque tanto a salubridade do país e de suas cidades quanto a estrutura para combater as

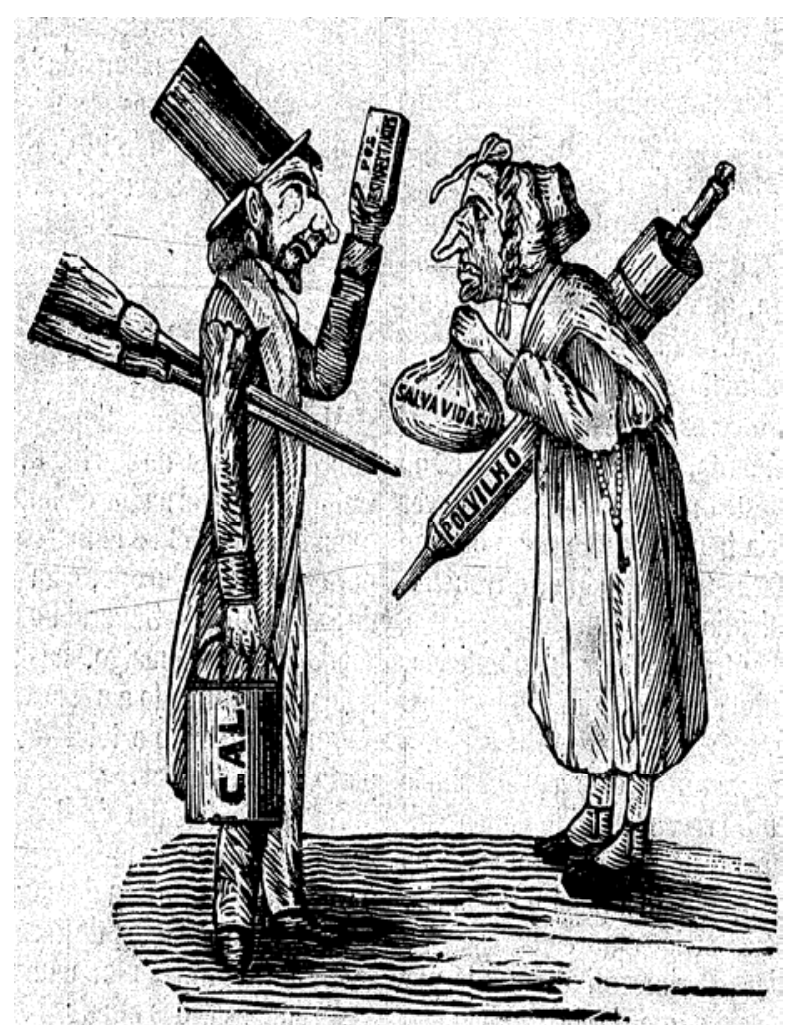

Figura 2.05: o que se fazer com o cólera? Alternativas diversas eram aventadas pela população.

Fonte: O Brasil Illustrado, Rio de Janeiro, n.06, 31 ago. 1856.

condições que propiciavam a disseminação dos males, como enfatizariam importantes médicos da estrutura de poder do Império, como José Pereira Rego (Barão do Lavradio e presidente da Junta Central de Higiene Pública entre 1863 e 1881) e Francisco de Paula Candido (primeiro presidente da Junta, onde permaneceu de 1850 a 1863, e médico do Imperador na década de 1850, ao menos). ${ }^{44}$

\footnotetext{
${ }^{43}$ R. Arrais, O Pântano e o Riacho, 2004, p.362.

44 José Pereira Rego [Barão do Lavradio], Memória histórica das epidemais de febre amarela e cólera-morbo que têm reinado no Brasil, 1876; F. Paula Candido, Relatório acerca da saúde publica, 1856, em especial a segunda parte, dedicada às "medidas sanitárias - interpretação dos fenômenos epidêmicos". Os dados apresentados no Relatório de Paula Cândido, ainda que imprecisos e incompletos, apontam para uma mortalidade de mais de 115 mil pessoas em diversas províncias do Império, de norte a sul, cf. Angela
} 
Havia um claro interesse político na retórica nos Prolegômenos de Domingos Peixoto, ressaltando diversas vezes a necessidade de continuidade dos esforços de estruturação dos serviços e preceitos da higiene pública do ainda Reino. Isso aponta inclusive para a luta pela legitimidade do saber médico (e pela circunscrição de suas atribuições, normalizando as práticas, as autorizações profissionais, o combate ao curandeirismo, a fiscalização sobre a fabricação de remédios etc.). Houve grande resistência cultural ao processo de monopolização da cura pelos médicos ao longo do século XIX. Diante de um quadro de precariedade de formação de profissionais médicos, a população continuava a usar, de maneira geral, os terapeutas populares, leigos. Durante a epidemia do cólera em Recife, em 1856, e.g., o curandeiro Pai Manoel (ou “doutor” Manoel da Costa, epíteto que tinha um quê de escárnio em relação aos médicos profissionais) chegou a receber autorização oficial para praticar suas artes da cura, evitando assim insurreições entre sobremaneira a população negra que lhe atribuía poderes mágicos para enfrentar a peste. ${ }^{45} \mathrm{E}$ mesmo quando da grande pandemia de influenza em 1918-19, em um momento de institucionalização praticamente definitiva da prática médica no Brasil, houve um esforço oficial e corporativo acentuado contra os curandeiros e seus remédios que prometiam curas milagrosas, não apenas entre a população pobre mas também entre pessoas mais ilustradas, conforme denunciaram vários periódicos. Artur Neiva, então diretor do Serviço Sanitário de São Paulo, formado pela Faculdade de Medicina do Rio de Janeiro, onde foi aluno de Oswaldo Cruz, apontaria que a presença e, principalmente, a influência de curandeiros e poções era incompatível com os "créditos de centro civilizado" de uma metrópole como São Paulo. ${ }^{46}$

As reclamações contra a "incúria da população" seriam uma constante ao longo do século XIX em muitas cidades brasileiras. Pedro Velho, Inspetor de Saúde Pública do governo provincial do Rio Grande do Norte diria, em 1886, que a situação "pouco lisonjeira" da higiene pública da capital Natal, diante de um quadro topográfico considerado favorável, recebendo ventilação e insolação, devia-se à falta

Ferreira, Anna Rachel Eduardo e George Dantas, Saudáveis trópicos: cidade, higiene e ordem para a Nação em formação (Brasil, 1850-1930), op. cit., p.447.

45 O episódio é narrado por Ariosvaldo Diniz, As artes de curar nos tempos do cólera: Recife, 1856, in S. Chalhoub et al. (orgs.), Artes e oficios de curar no Brasil, 2003, p.355-385.

46 Liane Bertucci, Remédios, charlatanices... e curandeiros: práticas de cura no período da gripe espanhola em São Paulo. In Chalhoub, S. et al. Artes e oficios de curar no Brasil, 2003, p.197-227. 
de asseio e de uma alimentação apropriada pela média da população. ${ }^{47}$ Observe-se que não se pretende aqui afirmar uma homogeneidade das formulações e ações higienistas em período tão longo e em contextos geográficos, políticos e econômicos com ritmos históricos distintos e particularidades. Como se afirmou na abertura do capítulo, o processo de institucionalização do saber médico no Brasil e, mais ainda, dos saberes sobre as cidades, não foi pacífico. Exemplo forte das marchas e contramarchas desse processo encontra-se, e.g., nos embates entre contagionistas e infeccionistas durante a epidemia do cólera de 1855-56 - e, em conseqüência, sobre a propriedade de se proceder ou não as quarentenas, que causavam grande embaraço à movimentação dos portos. O já citado relatório do médico Francisco de Paula Candido aponta para uma espécie de síntese entre as duas visões: ao observar a disseminação geográfica do cólera nas várias províncias afetadas, que "poupava" alguns núcleos urbanos que estavam inseridos na linha de propagação, o médico diria que a viagem do veneno (termo usado pelos contagionistas) tinha pouco impacto se não encontrasse condições propícias para evoluir - um meio insalubre, com umidade, águas paradas etc. (preocupação chave dos infeccionistas). ${ }^{48}$

Mas há, certamente, elementos comuns que foram mobilizados de maneira hegemônica na leitura crítica das cidades ao longo desse período. Além da dimensão material (parte dos elementos circunfusa), as práticas e os usos (os percepta e os gesta) do espaço urbano seriam vistos cada vez com mais cuidado e preocupação. A relação entre os vícios dos homens e os vícios das cidades (e das sociedades as quais expressavam) era um lugar-comum de viajantes e muitos médicos, cujo fundocomum de referências misturava leituras mesológicas, escritos moralistas e filosóficos, teorias deterministas e, também, a literatura de viagem, que, como se disse, muitas vezes serviu de referência para as reflexões de caráter mais científico.

${ }^{47}$ Cf. George Dantas, Linhas convulsas e tortuosas retificações: transformações urbanas em Natal nos anos 1920, 2003, p.38.

48 Francisco Paula Candido, Relatório acerca da saúde publica, 1856, p.67-88. 
Para Domingos Peixoto, além das "causas morbíficas" relacionadas à produção dos miasmas (oriundos da vegetação que se acumulava nas proximidades da área urbana, das águas estagnadas nas ruas e quintais, das "imundícies" que se encontravam em várias partes, como no Campo de Santana, das praias sujas, das inumações em igrejas e do matadouro), vários aspectos relacionados à vida social urbana afetavam diretamente as condições da higiene pública. A chegada e o depósito de escravos no Valongo, o hábito de se fritar peixes nas portas das tavernas, espalhando fumaça pela vizinhança e as bebidas fermentadas eram alguns desses elementos. Note-se, em especial, a condenação aos excessos, aos abusos, aos hábitos extremados - em relação à bebida, à alimentação, à ociosidade. ${ }^{49}$ Daí a languidez, a fraqueza e mesmo o sangue não concrescível que condenavam à debilidade o brasileiro. Para piorar, na leitura do médico, o costume do uso das amas-de-leite, mormente escravas negras, debilitava a possibilidade da boa educação moral. ${ }^{50}$

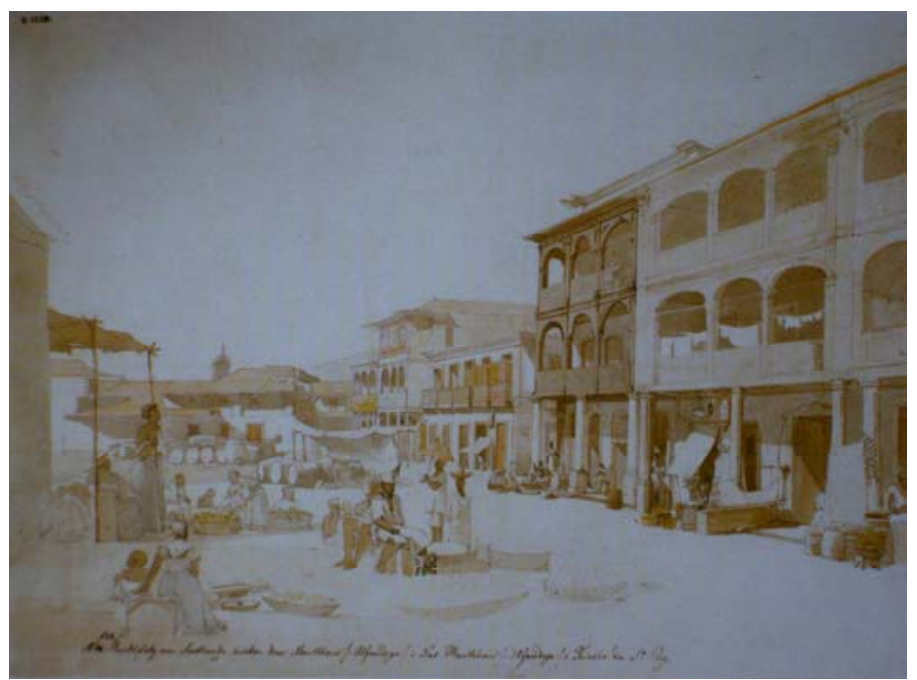

Figura 2.06: Thomas Ender, Mercado perto da praia atrás do trapiche da Alfândega, lápis e aquarela Fonte: Belluzzo, 1999, v.3 (fig.385)

\footnotetext{
${ }^{49}$ Domingos Peixoto, Prolegômenos [1820], op. cit., p.108-111.

50 "O que se deve esperar do aleitamento mercenário, feito mormente por pretas, sendo escravas o maior número delas? É impossível que essa casta de gente, quase sem religião e sem moral, oprimida e excitada a cada momento pela idéia de cativeiro, e capaz de todas as sortes de artifícios, empregue todo o desvelo e carinho na criação dos meninos (...)" (Ibidem, p.112-113).
} 
Condenava-se assim uma série de práticas que remontavam ao estatuto colonial das cidades, do seu espaço tomado pela "desordem" do populacho e da escravaria em suas atividades cotidianas, comezinhas, espalhando-se pelas ruas, calçadas e paredes, naquela algaravia de sons, ruídos e cheiros que espantara Koster e vários outros viajantes em suas chegadas às cidades luso-brasileiras.

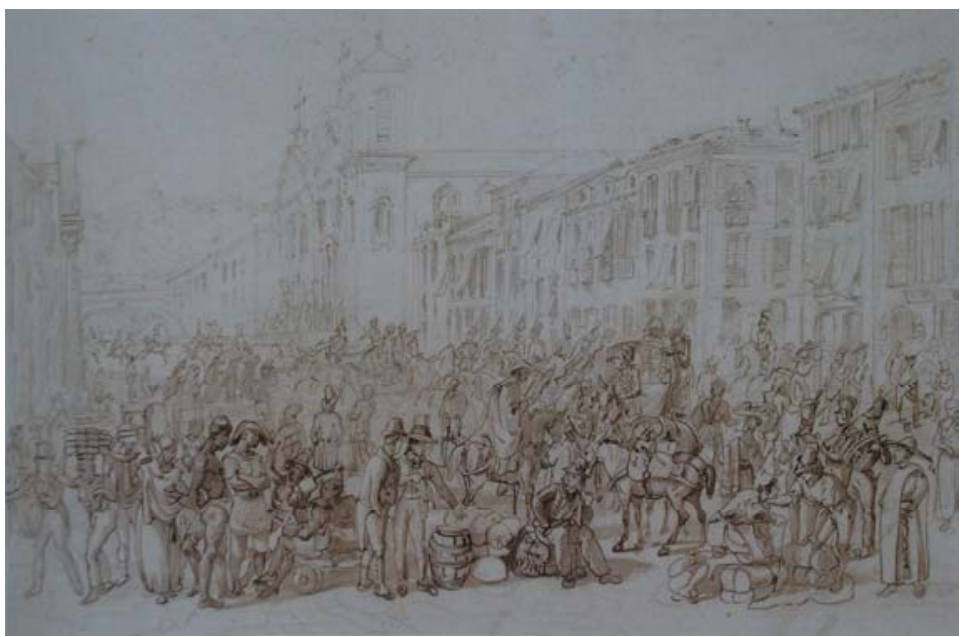

Figura 2.07: J. M. Rugendas, Rua Direita no Rio de Janeiro, lápis e nanquim sobre papel.

Fonte: Belluzzo, 1999, v.3 (fig.446)

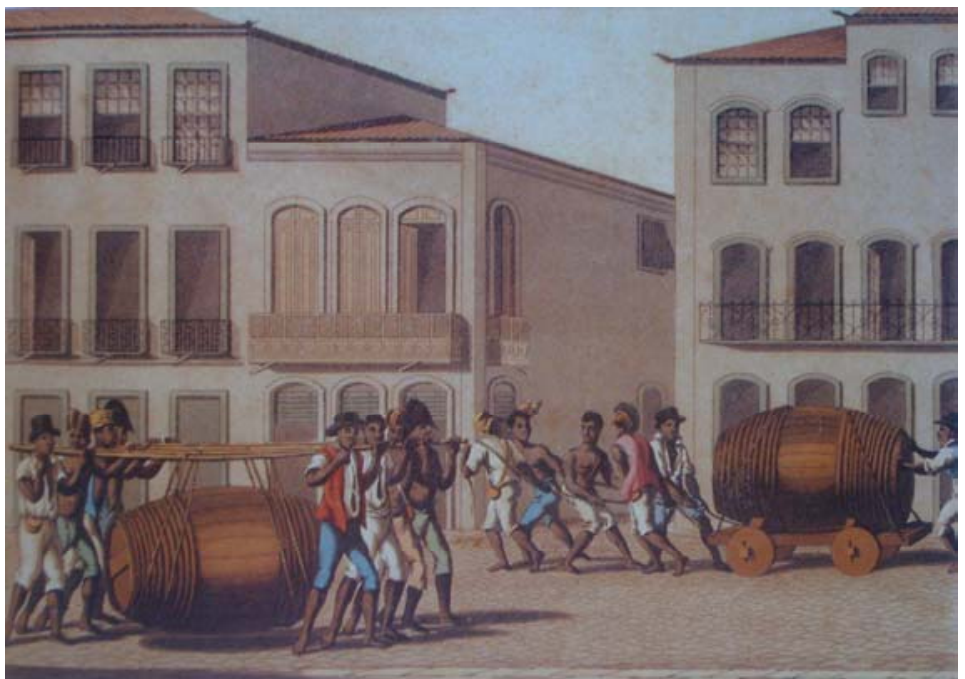

Figura 2.08: John Clarke e Henry Chamberlain, Pretos de ganho (no Rio de Janeiro), água-tinta colorida sobre papel.

Fonte: Belluzzo, 1999, v.3 (fig.470). 
Uma nova ordem precisava ser estabelecida para receber a Corte. Uma ordem para estabelecer o decoro, a higiene, a possibilidade de instaurar uma sociedade civilizada e abrigar o que passara a ser a capital do Império em 1808. Como discute o historiador Robert Pechman, uma ordem que, antes de ser urbana, seria cortesã, baseada na polidez, na moderação, na estetização do cotidiano. Uma ordem que prescindia da ordem (ou, melhor, da visão de desordem) colonial e, mais ainda, que precisaria suprimi-la ou enquadrá-la em esferas específicas. ${ }^{51}$ Essa leitura estava presente nos viajantes, como discutido no capítulo 1: Debret, e.g., faria uma dura crítica à colonização portuguesa e afirmaria que a obra de civilização só seria possível com a superação dos vínculos coloniais e com o apagamento da herança portuguesa. $^{52}$

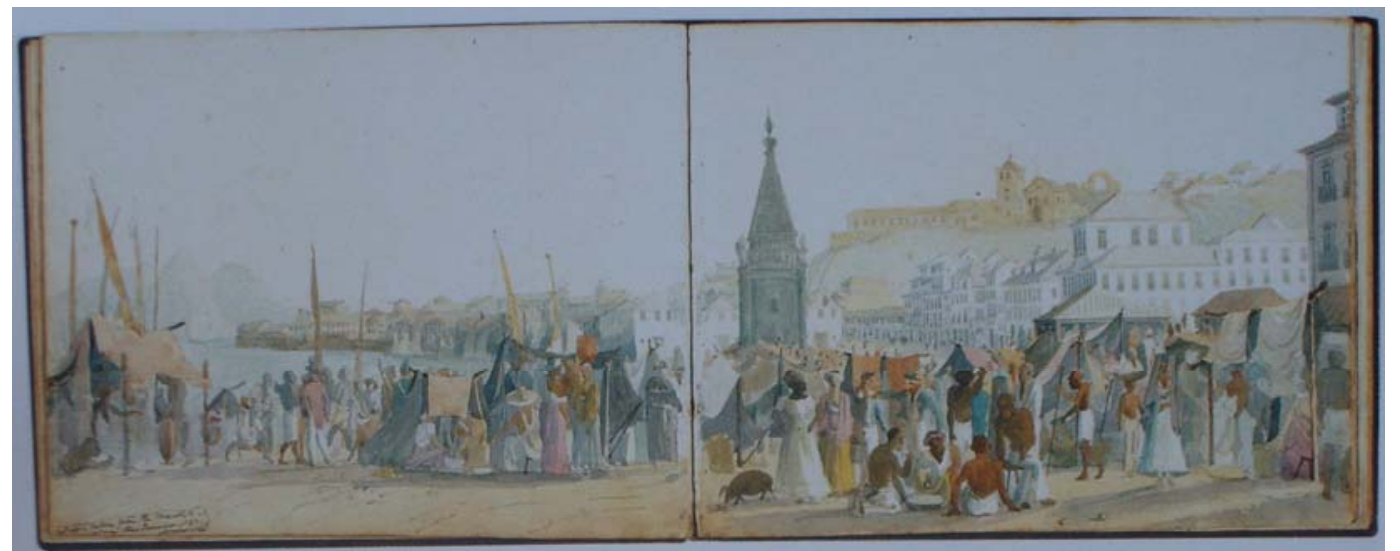

Figura 2.09: sketchbook de William Smith, Desenho tomado da praça do mercado, 1832, desenho aquarelado sobre papel.

Fonte: Belluzzo, 1999, v.3 (fig.474)

Ordem, enfim, para a qual a higiene era fundamental. Vieira Silva, em citação anterior, já falara que aterrar os lugares pantanosos era obra da "boa polícia". Polícia que, sabe-se, vem de pólis que, por sua vez, depreende polidez, como apareceria no Dicionário da Língua Portuguesa, de Almeida Prado, em $1868 .{ }^{53}$ Mas, antes ainda, a primeira entrada do verbete "polícia" no Dicionário de Bluteau já definia: "A boa ordem que se observa e as leis que a prudência estabeleceu para a sociedade humana

\footnotetext{
51 Robert Pechman, Cidades estreitamente vigiadas: o detetive e o urbanista, 2002, p. 23-117.

52 Amílcar Torrão Filho, $A$ arquitetura da alteridade: a cidade luso-brasileira na literatura de viagem (1783-1845), 2008, p.159160.

53 Cf. R. Pechman, op. cit., p.68-69.
} 
nas cidades"; acrescentaria ainda que a polícia "não se acha nos povos a que chamamos bárbaros, como v. g. o gentio do Brasil (...)". ${ }^{54}$

É muito provavelmente esse sentido de polícia que tinha Vieira Silva em mente quando a registra em suas Reflexões. As suas formulações não eram isoladas, certamente. Junto com a Corte, como se sabe, transferiram-se para o Rio de Janeiro as estruturas administrativas, instituições e suportes materiais (arquivos, bibliotecas etc.), para seu funcionamento. A Fisicatura do Reino foi instalada ainda em 1808, mesmo ano de criação das escolas médico-cirúrgicas de Salvador e do Rio de Janeiro. ${ }^{55}$ Em abril, pouco após a chegada da Corte, D. João VI conferiria atribuições ao intendente geral de polícia que lhe permitiam agir, de fato, como "um prefeito reformando sua cidade": cabia-lhe a responsabilidade pelo arruamento, abertura de estradas, conservação dos logradouros públicos até pela fiscalização do comércio vendas, iluminação, delitos da imprensa, repressão à mendicidade e vadiagem, etc.: ${ }^{56}$

Não é por outro motivo que as primeiras medidas, logo provavelmente as mais urgentes, sancionadas pelo intendente, assim de sua posse, dizem respeito à limpeza da cidade, às construções, ao comportamento no teatro, à vigilância dos botequins, à estatística da população etc. Medidas visivelmente necessárias à ordenação do espaço público, lugar de exercício da civilidade. ${ }^{57}$

A construção dessa ordem seria longa - a "praça venceu o engenho, mas aos poucos", como interpretaria Gilberto Freyre ${ }^{58}$ - e revela as incompletudes, características, ênfases e interesses em jogo no processo de modernização brasileiro ao longo do século XIX. Mais uma vez, corre-se o risco de homogeneizar leituras de contextos históricos diversos, mas, ao mesmo tempo, deve-se reconhecer que forças

\footnotetext{
${ }^{54}$ R. Bluteau, Polícia [verbete], Vocabulario Portuguez \& Latino..., 1712-1728 [edição on-line do IEBUSP], p.575.

${ }^{55}$ Cf. Lilia M. Schwarcz, O espetáculo das raças, 1993, p. 189-198; Tânia Pimenta, Terapeutas populares e instituições médicas na primeira metade do século XIX. In Chalhoub, S. et al. (orgs.) Artes e ofícios de curar no Brasil: capitulos de bistória social, 2003, p.308-330.

${ }^{56}$ Sobre as atribuições do intendente geral de polícia, cf. R. Pechman, Cidades estreitamente vigiadas: 0 detetive e o urbanista, 2002, p. 68-77, e Paulo Marins, Através da rótula, 2001, p.160-167; o papel civilizador, de estabelecimento de parâmetros de polidez, é muito claro, principalmente no enquadramento da população aos "termos do bem-viver", aos padrões de decoro público, tentando resolver caso a caso as querelas.

${ }^{57}$ Ibidem, p.73.

${ }^{58}$ G. Freyre, Sobrados e Mucambos: decadência do patriarcado rural e desenvolvimento do urbano, 2004 [1936], p.135.
} 
homogeneizantes atuaram nesse processo. A ênfase e o investimento das ações médicas estatais contra a febre amarela a partir de 1850, e.g., desnuda a neutralidade do discurso técnico: a epidemia era um entrave tanto ao projeto ideológico de fortalecimento racial e embraquecimento da população brasileira, porque atingia sobremaneira os imigrantes europeus, quanto ao desenvolvimento comercial, atravancando as atividades portuárias. Enquanto isso, a tuberculose, doença relacionada diretamente às más condições de moradia, trabalho e alimentação, foi a endemia que mais óbitos causou entre 1850 e 1920, atingindo diretamente a população pobre e negra. ${ }^{59}$

Forças e leituras homogeneizadoras serviriam para disseminar a noção (negativa) da intima relação entre os vícios da cidade e os vícios dos homens. A reiterada denúncia do enviesamento das ruas, do acanhamento das edificações, dos elementos naturais que impediam a livre circulação dos ventos, deixando os espaços sombrios, abafados, enfermiços, disseminaram-se para além dos círculos especialistas, tornar-se-ia lugar-comum, a despeito das particularidades de cada cidade, como, e.g., seriam os casos de Recife e Natal. ${ }^{60}$

A polidez dessa ordem cortesã que se tentava implantar (e por força, sedução e violência se fez) implicava também, conforme o verbete no dicionário de Bluteau, uma cidade regulada, governada com boa polícia - no trato, na conversação, nos costumes, nos gestos, na higiene pública e no asseio pessoal. O problema, contudo, persistia. E persistia porque os problemas eram estruturais e diziam respeito não apenas aos elementos naturais, como o Morro do Castelo, reiteradamente condenado, como pode se perceber em vários documentos a partir de meados do século XIX.

O relatório apresentado pelo engenheiro Henrique de Beaurepaire Rohan, então Diretor das obras municipais do Rio de Janeiro, à Câmara Municipal da Corte delimitava com clareza que os problemas relacionados à falta da boa polícia e, consequentemente, dos elementos fundamentais à insalubridade pública, derivavam da estrutura da cidade:

\footnotetext{
${ }^{59}$ S. Chalhoub, Cidade febril: corticos e epidemias na corte imperial, 1996, p.56-76; não se pode esquecer que a epidemia de febre amarela de 1849-1850 atingiu toda a família imperial, quando perderam um filho que tinha apenas um ano e meio de idade.

${ }^{60}$ R. Arrais, O pântano e o riacho, 2001, p.362-403; Angela Ferreira et al., Uma cidade sã e bela, 2008.
} 
O Rio de Janeiro participa de muitos dos defeitos que são ordinários nas cidades edificadas sem plano. É um deles a estreiteza das ruas, algumas das quais tem apenas trinta palmos de largura, que muito dificulta o trânsito, em ocasiões de concorrência. Conviria pois destruir-se essa imperfeição, como já foi indicado pelo Exmo. Tenente General Andréia, comandante do Imperial Corpo de Engenheiros, aproveitando também o ensejo para dar à cidade uma forma mais regular, às águas um esgote mais pronto, e aos habitantes uma residência mais cômoda, aprazível e sadia. ${ }^{61}$

A partir dá, o engenheiro arrolaria uma série de medidas que acabariam configurando, segundo a arquiteta Verena Andreatta, o primeiro plano urbanístico do Rio de Janeiro - que pôs em xeque diretamente toda a estrutura da cidade velha, colonial, como o erro de localização do matadouro, da proximidade com fontes miasmáticas, como o mangue da Cidade Nova, com os despejos públicos - que tornava "a praia e outros lugares da cidade de um desasseio e de uma indecência que cumpre evitar, por meio de alguma medida que se possa aplicar a todos os pontos mesmo centrais da cidade, como acontece nas [cidades] mais civilizadas da Europa". ${ }^{62}$

Por conta da epidemia do cólera de 1855-56, o diretor da Junta Central de Higiene Pública, Francisco de Paula Candido, propôs a criação de um sistema provisório para os despejos, enquanto não se construía o definitivo, baseado ainda no uso dos barris que seriam levados, em horários específicos, a depósitos distritais (calculados para receber os despejos de uma semana) e, daí, a fossos (que funcionariam próximo do que se entende hoje como aterro sanitário). Todo o processo seria marcado por medidas de desinfecção; haveria ainda privadas e mictórios públicos para o uso da população. O cálculo das imundícies da capital imperial debitava tanto a estrutura material da cidade quanto os costumes arraigados que não respeitavam os horários delimitados pelas posturas municipais e nem mesmo a importância dos lugares - para consternação do médico, despejos eram feitos inclusive ao lado do Paço Imperial. Assim, "por toda a parte, liberdade plena de

${ }^{61}$ H. Beaurepaire Rohan, Relatório apresentado à Ilma. Câmara Municipal do Rio de Janeiro, 1843, In V. Andreatta, Cidades quadradas, paraísos circulares: os planos urbanísticos para o Rio de Janeiro no século XIX, 2006, anexos, p.04; grifos nossos.

62 Ibidem; sobre o "plano" de Beaurepaire Rohan, cf. V. Andreatta, Cidades quadradas, paraísos circulares: os planos urbanísticos para o Rio de Janeiro no século XIX, 2006, p.83-135, que efetua um importante trabalho de descrição e reconstituição gráfica das propostas apenas escritas. 
envenenar o ar da cidade". ${ }^{63}$ Ao historiar o que considerava como as duas grandes moléstias a atravancar o progresso do Brasil no século XIX, Pereira Rego afirmaria que a epidemia de febre amarela que irrompera em 1849 viera no bojo do "mais deplorável estado de nossa higiene pública e polícia sanitária, pelo desleixo e abandono em que jazia tudo que respeita à saúde pública". ${ }^{64}$

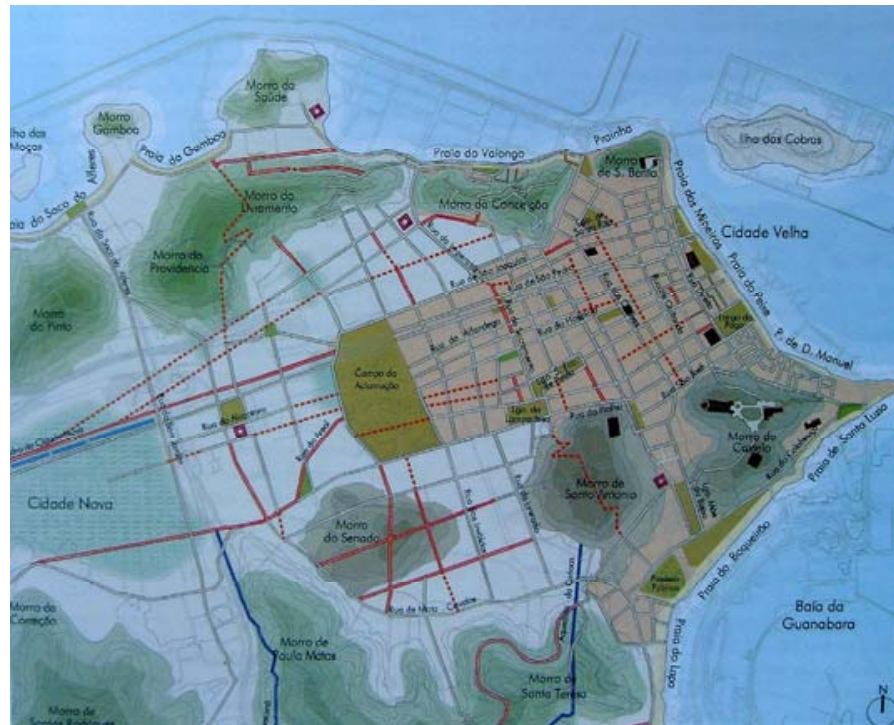

Figura 2.10: mapa interpretativo das propostas de Beaurepaire Rohan, 1843 (sobre a base cartográfica digital atual da cidade) Fonte: V. Andreatta, 2006, p.55.

Além da leitura higienista, que reiteraria ademais a condenação ao Morro do Castelo, Beaurepaire Rohan proporia a organização de um "plano colossal" para coordenar o conjunto de medidas necessárias ao melhoramento da cidade. Essa noção de plano - não traduzido graficamente à época conquanto descrito em detalhes - o levaria a condicionar, e.g., a reforma geral do calçamento da cidade com muitas ruas em "estado de ruína" ou com tudo por fazer - com um "sistema de esgote". ${ }^{65}$

${ }^{63}$ F. Paula Candido, Relatório acerca da saúde publica, 1856, p.70-77; observe-se que Candido não se estende em comentários sobre a necessidade de remoção do matadouro, sobre as inumações em solo sagrado e sobre a construção de moradas salubres pois considerava que a utilidade de tais medidas estava mais do que demonstrada.

${ }^{64} \mathrm{~J}$. Pereira Rego, Memória histórica das epidemias de febre amarela e cólera-morbo que têm reinado no Brasil, 1873, p.17.

${ }^{65}$ B. Rohan, op. cit., p.05, 08. 
Ainda assim, pensando pragmaticamente, os elementos do "plano" de Beaurepaire Rohan não iriam prever o arrasamento do Morro do Castelo, conquanto o seu fim implicasse "em extensão, salubridade e embelezamento, como foi demonstrado pelo Ilmo. Dr. Emílio Maia, no seu relatório à Academia de Medicina". ${ }^{66}$ A clareza das limitações orçamentárias e de ação da câmara municipal impunham a delimitação de propostas que se considerava exeqüíveis.

A formulação de que a consecução dos sistemas de saneamento (abastecimento de água, coleta, canalização e tratamento das águas pluviais e dos esgotos) seria fundamental para superação dos problemas gerais de salubridade e, assim, para viabilizar a transformação e construção de uma cidade progressista, civilizada, moderna, ganharia corpo até o final do século XIX. Nesse sentido, a obra de diversos engenheiros como Aarão Reis, Francisco de Paula Bicalho, Lourença Baeta Neves, Theodoro Sampaio, Henrique de Novaes e, sobremaneira, Francisco Rodrigues Saturnino de Brito estruturaram uma prática sobre o desenho das reformas, da expansão e mesmo da criação de cidades por todo o Brasil. O que exigiu uma série de leituras sobre as estruturas urbanas herdadas do período colonial - que se expandiram e atravessaram o período imperial.

\section{2 o traçado sanitário das cidades}

O Le tracé sanitaires des villes, publicado por Saturnino de Brito em 1916, na França (por ocasião do Congresso da Associação de Técnicos Municipais, órgão do qual o autor era membre d'hounner como representante do Brasil), será considerado aqui como uma suma desse conhecimento que vinha se estruturando desde o final do século XIX. Isso por várias razões. Antes de mais nada, porque o texto faz um apanhado e reflete sobre planos e obras já realizadas ou em andamento que serviriam como parâmetro para o próprio Brito e, principalmente, para seus pares profissionais. Dentre esses planos e obras, destacavam-se os de Santos e Recife, mas há também referências a Campos, Vitória (Novo Arrabalde) e Parahyba do Norte (atual João Pessoa). Em segundo lugar, porque exprime vários dos pressupostos teóricos que informam a leitura e a formulação de soluções, demonstrando que a

\footnotetext{
66 Ibidem, p.04.
} 
formação do urbanismo sanitarista não significou uma mera continuação das leituras e ações higienistas, embora delas se aproprie claramente. Há aqui uma cisão que se manifestaria, e.g., ao negar a possibilidade de analogia entre o ser humano como organismo e a cidade como organismo: "On multiplie les études pour amener les efforts vers une orientation organique, c'est-à-dire, esthétique, rationnelle, pratique; mais on ne peut pas songer à résoudre tous les problèmes locaux par des règles ou des types classiques L'organisme-ville est comparable à l'organisme-homme il est encore plus complexe".67

Em meio às várias citações, desde as mais eminentemente técnicas até aquelas voltadas para o problema do plano da cidade (como The sanitary side of town planning, de Alfred J. Price, e do artigo de Nelson P. Lewis para o Congresso Internacional de Engenharia, realizado em San Francisco, 1915), destaca-se a leitura do livro de Camillo Sitte, não a partir do original, mas em sua edição francesa de 1902, L'Art de bâtir les villes. Leitura que é marcada, claro, pelos interesses do leitor e, antes ainda, pelas alterações operadas pelo tradutor para o francês, Camille Martin, que fez substanciais acréscimos, compondo praticamente um livro diverso, inclusive com novas ilustrações. ${ }^{68}$

Essa questão está longe de ser de somenos importância. Afinal, como o demonstrou o professor Carlos de Andrade, recuperando a fortuna crítica do influente livro de Camillo Sitte para o nascente urbanismo moderno, é principalmente a partir da edição francesa de 1902 que o livro de Sitte circularia como, e.g., no Town Planning in practice (1909), de Raymond Unwin, na Société Française des Urbanistes e nas próprias leituras de Brito. Assim, muitas das críticas feitas às idéias de Sitte são, na verdade, formulações sobre trechos transfigurados por Martin, que chegara, inclusive, a escrever um novo capítulo dedicado ao tema das ruas em substituição ao capítulo sete original - "praças do norte da Europa". 99

\footnotetext{
${ }^{67}$ F. Saturnino R. de Brito, Le trace sanitaire des villes: technique sanitaire urbaine. [1916], in Obras Completas de Saturnino de Brito, v. 20, 1944, p.34.

68 George R. Collins e Christiane C. Collins, Camillo Sitte y el nacimiento del urbanismo moderno [1965], in C. Sitte, Construcción de ciudades segun principios artísticos, 1980.

69 Cf. Carlos de Andrade. Camillo Sitte, Camille Martin e Saturnino de Brito: traduções e transferências de idéias urbanísticas, in L. C. Q. Ribeiro e R. Pechman, Cidade, povo e nação. Gênese do urbanismo moderno, 1996, p.287-310.
} 
Isso implica considerar que Brito fez uma leitura interessada em cima de uma leitura que, por sua vez, já operara ênfases, reescritas, interesses. Leitura interessada todas as leituras costumam ser. Em Saturnino de Brito, a leitura de Sitte buscaria os fundamentos para a defesa do plano contra o crescimento desordenado das cidades. Como afirmaria logo no prefácio, para Brito era melhor algum plano do que nenhum - não fazê-lo implicaria deixar

(...) l'extension des villes dépendre du hasard, des caprices des propriétaires et des administrations locales; les faits ont montré partout les graves inconvénients, aux points de vue technique et économique, de l'imprévoyance touchant le développement des réseaux de distribution d'eau potable, et principalment des réseaux d'égouts sanitaires et d'égouts pluviaux. ${ }^{70}$

Fazer-se ao acaso revela as muitas leituras de Sitte mas, também, uma preocupação fundamental de Brito com a realidade das cidades brasileiras em que vinha atuando havia mais de duas décadas. Assim, por meio dos argumentos de Sitte,

$\mathrm{O}$ engenheiro

brasileiro propõe

demonstrar que

'l'irrégularité des

plans des villes

anciennes venait du sentiment artistique, mais que'on ne doit plus laisser au hasard l'extension des villes; au contraire, il faut

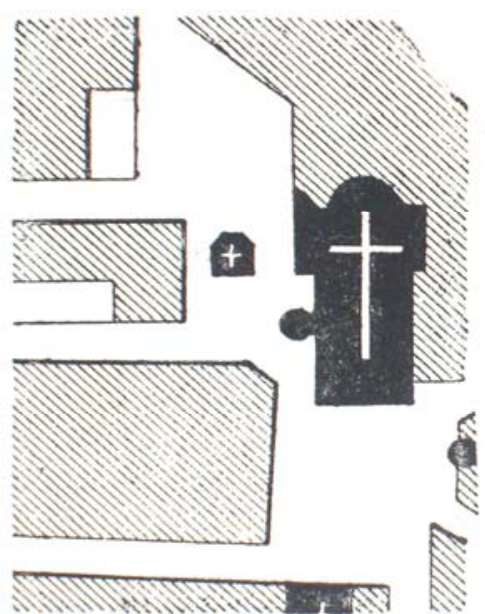

Figura 2.11: os exemplos sitteanos de Ravenne (esq.) e Pádua (dir.) evocados por Saturnino de Brito para falar do sentimento artístico presente na irregularidade das cidades antigas européias. Fonte: S. Brito, Tracé Sanitaire des villes, 1916.

en dresser à l'avance

les plans

d'ensemble". ${ }^{71}$ Não seria o acaso, o capricho de um indivíduo ou uma conjunção de fatores fortuitos que levariam à beleza pitoresca da irregularidade de praças e ruas, mas, sim, e mesmo inconscientemente, o vínculo à tradição de cada época - que

\footnotetext{
70 Saturnino de Brito, Trace sanitaire des villes, op. cit., p.28.

${ }^{71}$ Ibidem, p.35.
} 
combinaria, com arte, o pitoresco natural, a grandeza das construções, o estilo e a disposição das massas. ${ }^{72}$
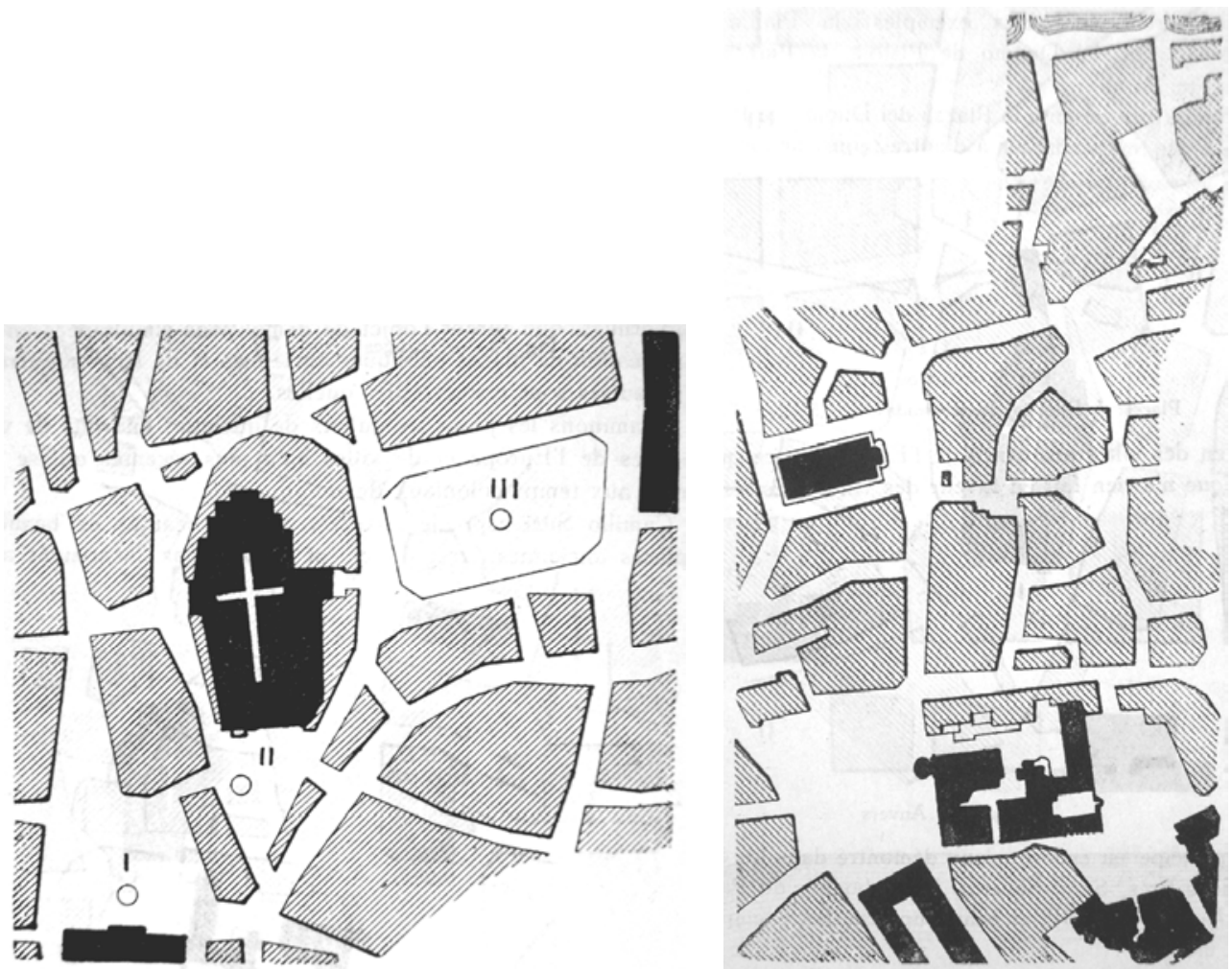

Figura 2.12 (esq.): Anvers

Fonte: S. Brito, Tracé Sanitaire des villes, 1916

Figura 2.13 (dir.): área central de Bruges Fonte: Ibidem.

Arte que poderia ser vista nos exemplos sitteanos que Brito incorpora a seu texto - as Piazze del Duomo em Ravenne e em Pádua, a catedral de Anvers e os pequenos largos e praças de Bruxelas. Arte que não se encontraria nos exemplos evocados das cidades "bien plus recentes qui se sont formées aux temps coloniaux du Brésil". ${ }^{73}$ Os exemplos são retirados de Recife e Santos, cidades que conhecia bem por conta de sua longa estadia em ambas, conduzindo os trabalhos de planejamento e execução das redes de saneamento e de expansão urbana, com claro impacto sobre as estruturas já existentes.

\footnotetext{
72 Cf. Ibidem, p.35-36; as citações de Brito baseiam-se na edição de 1902 do livro de Camillo Sitte.

73 Ibidem, p.37.
} 
Les exemples des plans des figures [européias] peuvent être compares aux exemples des plans des figures [brasileiras], de quelques places et rues des villes de Santos et de Recife, également irrégulières; elles n'ont pas cependant la beauté que'on ont aux exemples nombreux pris en des villes anciennes de l'Europe, parce que le sentiment artistique n'a rien em faveur des villes brésiliennes, en les dotant de beaux édifices harmonieusement disposés, comme il n'a rien fait aussi pour embellir la plupart d'autres places et rues irrégulières de l'Europe, même tout pres de celles qui bénéficièrent d'une préférence quelquefois fortuite. Quelquesunes des rues et des places représentées [das cidades brasileiras] sont aujourd-hui modifiées sans aucune orientation esthétique ou rationelle. ${ }^{74}$

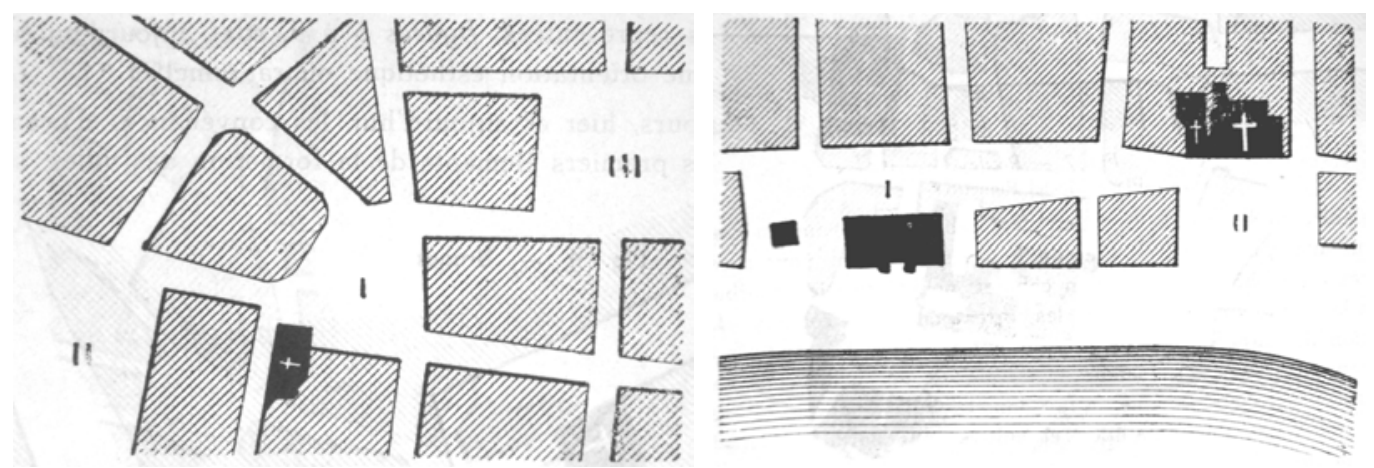

Figura 2.14 (esq.): Santos - praças do Rosário (I), Andradas (II) e Mauá (III) Fonte: S. Brito, Tracé Sanitaire des villes, 1916.

Figura 2.15 (dir.): Santos, Praça da República Fonte: Ibidem.

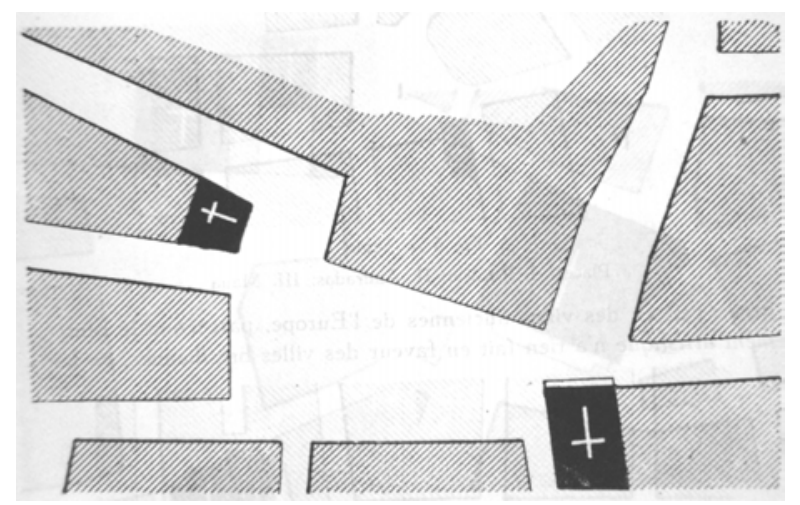

Figura 2.16: Recife, Praça Maciel Pinheiro Fonte: Ibidem.

Para Brito, o problema não estaria na irregularidade em si. Inclusive, quando o terreno fosse acidentado, com diferenças de nível expressivas, o traçado irregular, sinuoso ou que combinasse ortogonalidade e irregularidade era a melhor solução técnica - para implantação das redes de saneamento, dos sistemas de circulação etc.

\footnotetext{
${ }^{74}$ Ibidem, p.39-41.
} 
Esse é o cerne da crítica de Brito ao traçado de Belo Horizonte, e.g., para a qual evocaria Nelson Lewis: "La symétrie sur un plan et la symétrie sur le terrain sont choses très différents". ${ }^{75}$

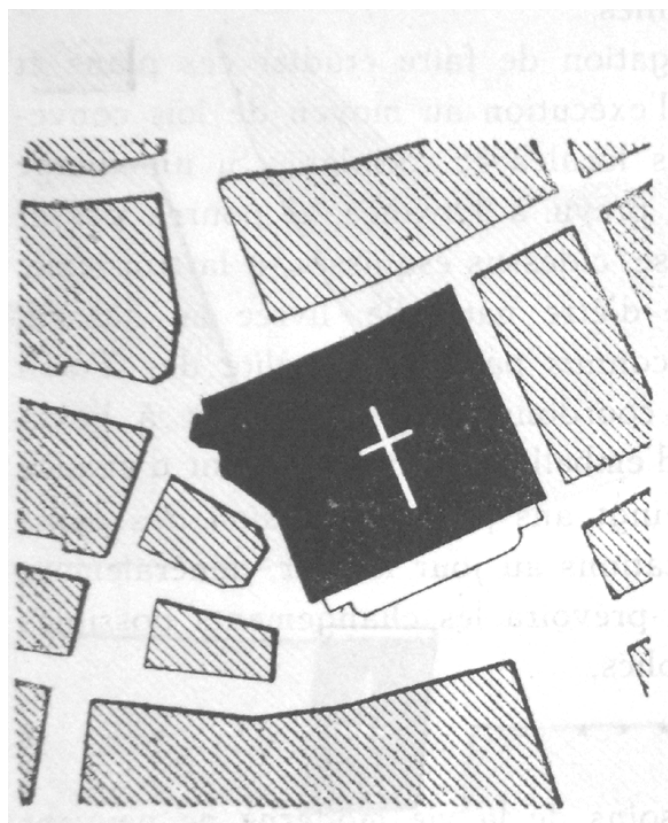

Figura 2.17: Recife, Largo do Corpo Santo (esq.) e Pátio do Carmo (dir.) Fonte: S. Brito, Tracé Sanitaire des villes, 1916.

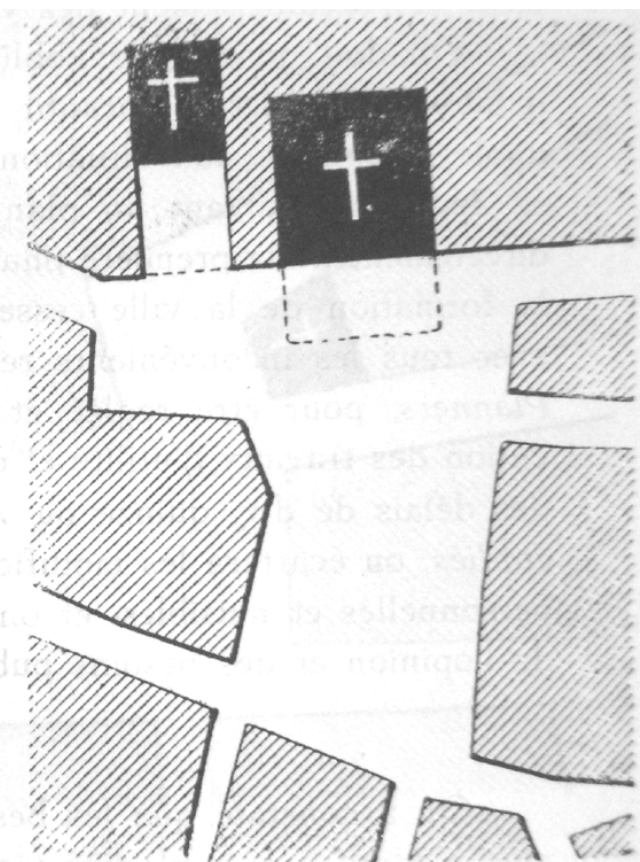

Esse seria, a propósito, o fundamento para o delineamento da proposta para João Pessoa, em 1913:

(...) indico alguns melhoramentos para a cidade existente, alargando várias ruas destinadas a realizarem a fácil distribuição do trânsito; projeto ruas novas, sem a preocupação inconveniente, e hoje condenada, de alinhar ruas retas e longas, cortando-se em ângulos retos; procurei traças as ruas novas de modo a terem todas uma declividade favorável ao escoamento pluvial e à execução dos esgotos. ${ }^{76}$

\footnotetext{
75 Ibidem, p.51.

${ }^{76}$ F. Saturnino R. de Brito, Saneamento de Paraíba do Norte (João Pessoa) [1913], in Obras Completas de Saturnino de Brito, v.5, 1943, p.291; grifos nossos.
} 


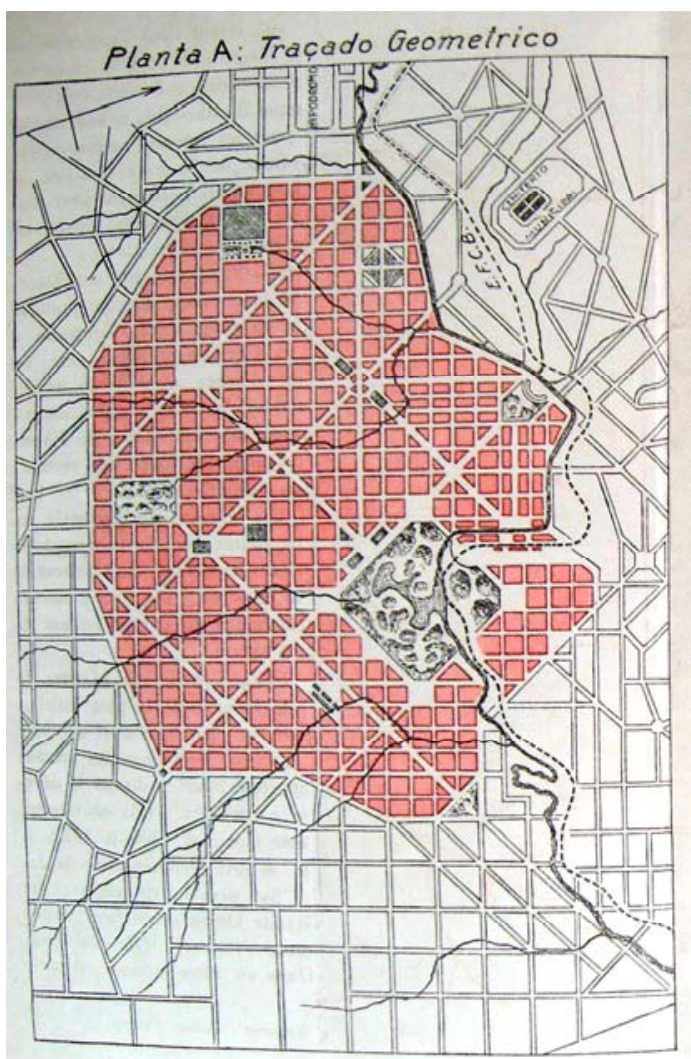

Planla B: Traçado Sanitario P. Ix

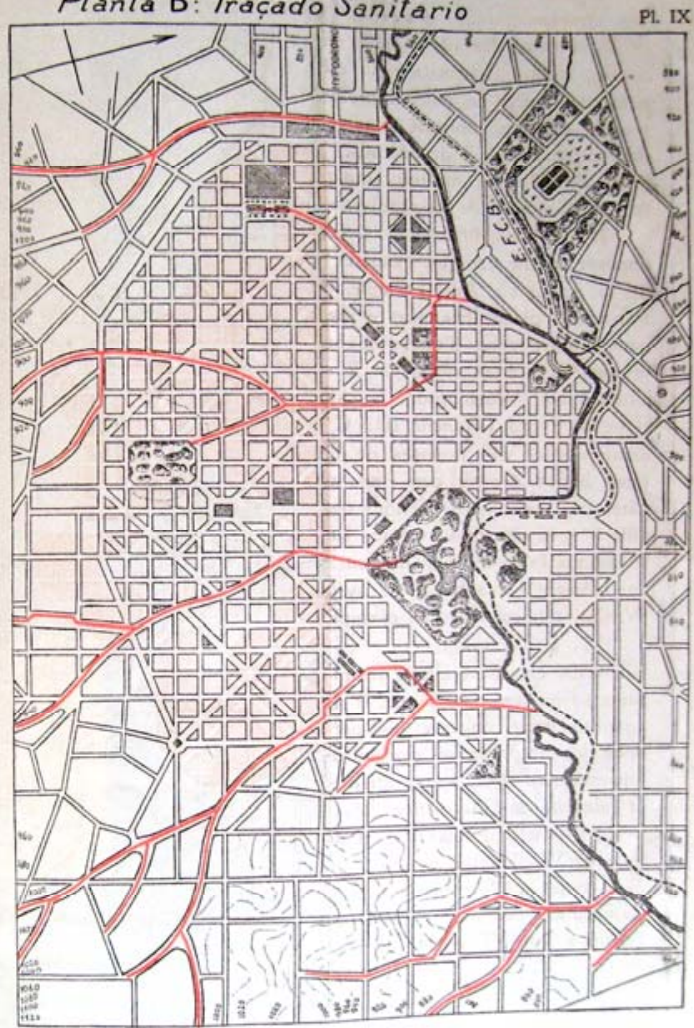

Planta de Bello Horizonte (MINAS)

Figura 2.18: à esquerda, o traçado regular de Aarão Reis que se sobrepõem às condições topográficas do sítio; à direita, a correção segundo os princípios do traçado sanitário.

Fonte: S. Brito, Tracé Sanitaire des villes, 1916. 
Isso serviria de princípio para corrigir as eventuais falhas no traçado do plano, diante de uma planta topográfica original que Brito reputava como falha e insuficiente. $\mathrm{O}$ traçado sanitário viabilizaria assim a conexão e a fluidez da circulação entre o platô elevado da cidade alta - núcleo original de ocupação com trama regular

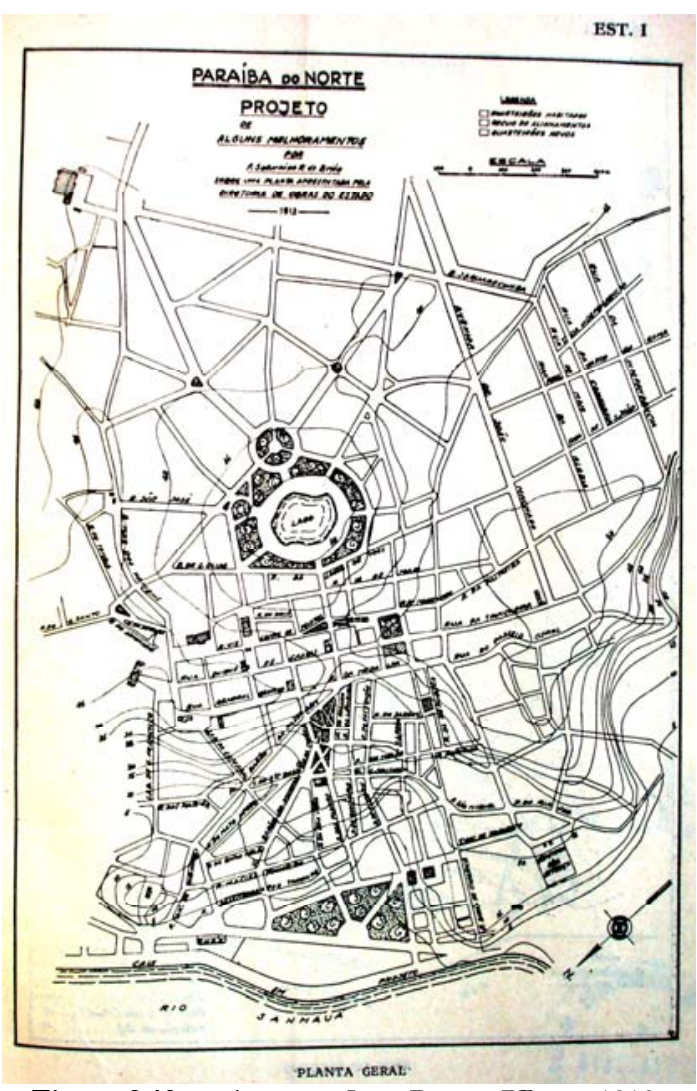

Figura 2.13: projeto para João Pessoa-PB, em 1913 Fonte: S. Brito, Tracé Sanitaire des villes, 1916.

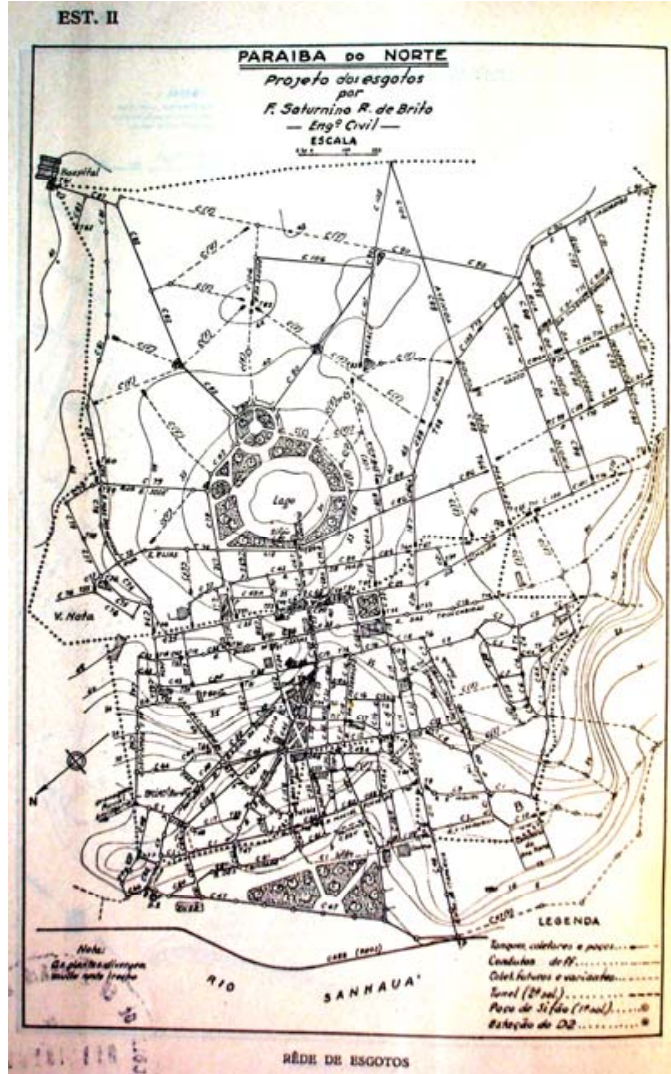

Figura 2.14: rede sanitária que informa e determina a solução do traçado viário (que já aproveita a situação existente). Fonte: S. Brito, Tracé Sanitaire des villes, 1916.

do final século XVI - e a irregularidade que descia a encosta em direção ao Varadouro e ao Rio Sanhauá. Mais ainda, apontava para a possibilidade de ocupação em direção leste, expandindo a cidade para além dos seus limites seculares, dominando a antiga Lagoa dos Irerês (transformada, no projeto, em parque). ${ }^{77}$

\footnotetext{
77 As obras de saneamento seriam realizadas apenas a partir de 1922 e concluídas em 1926; cf. Francisco Sales Trajano Filho, D.V.O.P.: arquitetura moderna, estado e modernização (Paraíba, década de 1930), 2003, e M. Cecília Almeida, Espaços públicos em João Pessoa (1889-1940): formas, usos e nomes, 2006, p.86-87, 99-102, 160 et seq.; uma leitura detida do plano, mostrando incongruências entre os próprios princípios de Saturnino de Brito e algumas das soluções apresentadas (compondo um traçado que não seria o melhor do ponto de vista sanitário), encontra-se em Alberto Sousa, Helena Nogueira e Wylnna Vidal, Inovação no urbanismo brasileiro da Primeira República: o traçado de Saturnino de Brito para a expansão da capital paraibana, Arquitextos, mar. 2006.
} 
O imperativo era sanitário - que subordinaria as outras dimensões que deveriam ser consideradas na elaboração e execução de um plano geral para uma cidade, nova ou existente. Como diria Brito, ao referir-se aos planos de L'Enfant para Washington e de Aarão Reis para Belo Horizonte:

Il faut maintenir ce point de vue relatif dans l'organisation des nouveux tracés des villes, de même que pour le jugementet la révision des plans déjà dressés: ceux-ci doivent être respectés, malgré l'accusation du manque d'esthétique, quand ils représentent aussi le schéma prévu pour les travaux sanitaires; lês modifications ne doivent jamais influer sur le tracé sanitaire ou doivent se limiter à des détails. L'architecte compétent peut toujours embellir les endroits indiqués par les besoins artistiques, indépendamment de la régularité géométrique du plan. ${ }^{78}$

Essa questão seria reiterada diversas vezes, quase como um leitmotiv dos engenheiros que trabalharam dentro da perspectiva do urbanismo sanitarista. Em texto sobre os melhoramentos do Rio de Janeiro, publicado em 1927, pouco antes do convite oficial ao arquiteto Alfred Agache, Brito voltaria mais uma vez a defender a necessidade de se trabalhar "o problema integral" das cidades sob o seu "duplo aspecto - o utilitário e o estético":

Sem essa capacidade especial, torna-se indispensável a colaboração de outros técnicos. A injunção de Camillo Sitte, para que o engenheiro que projeta arruamentos consinta que o artista olhe sobre o ombro e modifique algumas vezes a direção da régua e do compasso, junte-se o conselho para que o artista que projeta permita que o engenheiro municipal e o sanitário também modifiquem algumas vežes o "pistolet" da estética, ou mesmo o substitua momentaneamente pela régua. ${ }^{79}$

Sitte permaneceria como referência, é certo - mesmo em meio às discussões sobre a delimitação profissional de responsabilidades sobre os problemas da cidade. Mas a leitura que não encontrara o "sentimento estético" nas cidades antigas brasileiras deriva de Sitte tão-somente? Ou, melhor, deriva de fato da versão de Martin do livro de Sitte?

Aqui, pode-se especular, a vivência das muitas cidades por onde passou, trabalhando, elaborando planos, projetos de redes técnicas, pesava-lhe mais na

\footnotetext{
${ }^{78}$ Saturnino de Brito, Trace sanitaire des villes, op. cit., p.50.

79 Idem, Os melhoramentos do Rio de Janeiro, in Obras Completas de Saturnino de Brito, v. 20, 1944, p.181-182; grifos nossos.
} 
delimitação dos parâmetros de julgamento. Oriundo do ambiente cultural técnico em que Brito se movia, pesava-lhe praticamente um século de leitura escrutinadora e depreciativa contra as cidades antigas, tanto européias ${ }^{80}$ quanto brasileiras, e os seus cheiros, barulhos, promiscuidade, falta de asseio e de decoro. Afinal, alguns dos exemplos evocados das cidades brasileira, como o do Largo do Corpo Santo, em Recife, encontrava-se uma configuração que serviria aos princípios sitteanos.

Observe-se, portanto, algumas das leituras realizadas ou esposadas por Saturnino de Brito que são anteriores ou, no máximo, contemporâneas a 1902 (ano da publicação da edição francesa do livro de Camillo Sitte). ${ }^{81}$ Salvo engano, uma das primeiras referências a Sitte apareceria nos relatórios dos trabalhos de Santos referentes a 1905 e 1906 (o texto deve ser de meados de 1907, pois Brito refere-se a Sitte ao lado de Vierendeel e de Joseph Bouvard, que "passou pelo Rio de Janeiro para ir reformar Buenos Aires" havia pouco, os três autores como exemplos da capacidade de diferenciar o que se vê na planta e o que aparece na rua, transformando em belezas artísticas o "suposto defeito de plano" ou o "acidente topográfico"). ${ }^{82}$

Em Campos, cidade natal do engenheiro, no Vale do Paraíba fluminense, iria descrever a cidade a partir da preocupação técnica com a salubridade, com o decoro, com a possibilidade de viver bem o espaço público e o espaço privado da habitação:

(...) as ruas em geral são mal lançadas e, na parte antiga, estreitas $e$ irregulares; a declividade é geralmente insuficiente para o

\footnotetext{
${ }^{80} \mathrm{Via}$ autores, e.g., sainsimonistas que tiveram clara repercussão na formação politécnica francesa e, em conseqüência, na politécnica do Rio de Janeiro, sobremaneira, onde se formaram Saturnino de Brito, em 1886, e Aarão Reis, em 1874 (quando a Escola passou de Central à Politécnica); cf. M. Cristina Leme, Urbanismo no Brasil. 1895-1965, 1999, p.448-451, 453-455; Heliana Salgueiro, Engenheiro Aarão Reis: o progresso como missão, 1997; idem, O pensamento francês na fundação de Belo Horizonte: das representações às práticas, in Cidades capitais do século XIX: racionalidade, cosmopolitismo e transferência de modelos, 2001c; Antoine Picon, Racionalidade técnica e utopia: a gênese da Haussmannização, in Cidades capitais do século XIX: racionalidade, cosmopolitismo e transferência de modelos, 2001.

81 (nota pessoal) estivemos por duas vezes, entre 2000 e 2001, no arquivo morto do Laboratório Técnico Hidroesb, no Rio de Janeiro, onde se encontra o "espólio" do Escritório Saturnino de Brito, e encontramos apenas alguns livros, cadernetas de campo e grande parte dos projetos originais, desde antes da fundação do próprio Escritório (em 1920) até o fechamento das atividades, na década de 1970. O livro de Camillo Sitte não fazia parte desse acervo.

${ }^{82}$ Cf. F. Saturnino R. de Brito, Saneamento de Santos, Relatório dos trabalhos de 1905-1906 [1907], in Obras completas de Saturnino de Brito, v.7, 1943, p.50-51; Bouvard foi contratado em 1907 pela intendência de Buenos Aires para realizar um plano de melhoramentos; em julho desse ano estava de volta a Paris, cf. Adrián Gorelik, La grilla y el parque, 1998, p.195; M. Cristina Leme, Urbanismo no Brasil, 1999, p.544-45.
} 
escoamento pelas sarjetas. As praças que existem são abandonadas (...).

(...) $\mathrm{O}$ asseio e a propriedade do hábito externo da cidade são tão necessários quando para o hábito de cada indivíduo no lar e em sociedade. Vemos aqui generalizada a antiga e detestável construção colonial, tanto para o miserável casebre como para as habitações comuns e para os próprios casarões, com pretensões a palacetes; sempre a falta de ar e de iluminação no interior (...). ${ }^{83}$

Seria em Campos que Brito desenvolveria a proposta do quarteirão com vielas sanitárias - que serviria depois de referência para os projetos de Santos e Recife. Apesar da leitura condenatória da parte antiga, o engenheiro não propunha transformá-la, por questões pragmáticas. Deixavam-se assim as "ruas tortas e estreitas do centro da cidade" como estavam, pois os alinhamentos e retificações seriam economicamente inviáveis para o orçamento de uma cidade de pequeno porte. Importante, no caso, era planejar a expansão, as novas áreas, enquanto remediavam-se os becos insalubres com calçamento e esgotamento. ${ }^{84}$

Brito esposaria a leitura higienista que encontraria na cidade o problema fundamental - o que levava, inclusive, a embaraçar as condições naturais favoráveis à salubridade. Em Campos, citaria e elogiaria relatório do médico Pereira Nunes, de 1902, que afirmava:

Realmente Campos, dotada pela natureza de condições topográficas excepcionais para ser em todos os sentidos a sultana do Paraíba, foi, pelos desvios da engenharia indígena e dos construtores coloniais, transformada em uma cidade de ruas tortuosas, becos e vielas sombrias, cheias de casebres escuros e insanáveis, criando assim um meio nosológico de condições semelhantes a muitas cidades asiáticas, onde a peste é endêmica. ${ }^{85}$

O texto do médico constitui quase uma síntese da leitura negativa que foi se estruturando sobre a cidade colonial. Imagem que evocaria também, ainda que de maneira vaga, um tema comum a muitos viajantes, a dizer, a proximidade com as imagens das cidades asiáticas ou orientais de maneira geral, ecoando noções de confusão, reclusão, vida privada sobrepondo-se à vida privada, perigos e doenças

${ }^{83}$ F. Saturnino R. de Brito, Saneamento de Campos [1903], in Obras completas de Saturnino de Brito, v.6, 1943, p.76-77; grifos nossos.

84 Ibidem, p.193-196.

85 Ibidem, p. 79. 
exóticos, enfim, configurações do orientalismo. ${ }^{86}$ Esse tipo de leitura encontraria paralelo durante o desenvolvimentos dos projetos e obras para Recife, em especial na leitura da produção do médico Octavio de Freitas (Brito citaria várias passagens de "O clima e a mortalidade da cidade do Recife", de 1905), construindo a mesma noção de que o território da cidade era naturalmente propício à salubridade. Era na construção material da cidade que se encontravam os defeitos - nas habitações insalubres, nas condições e materiais empregados na construção, na localização adensada, parede com parede, criando alcovas, no pouco asseio empregado na manutenção etc - que a transtornavam. ${ }^{87}$

As obras de modernização - da construção das redes técnicas em conjunto com as obras de embelezamento levadas a cabo por outros setores da prefeitura do Recife - seriam fundamentais para dar "à cidade um aspecto mui diferente da feição colonial e tristemente mórbida que a caracterizava". ${ }^{88}$

A leitura do erro que se inscreve nas origens das vilas e cidades fundadas pelo colonizador português já aparecera antes, quando efetuou os estudos para o Novo Arrabalde, área de expansão de Vitória. Brito concedia que a ocupação original derase sob os imperativos da defesa. Contudo, essa justificativa não explicaria o desenvolvimento que acontecera ao longo da história, pois na margem oposta da ilha "sobravam terras em melhores condições":

Se, porém, esta justificativa corre paralela ao natural egoísmo do ocupador lusitano, ela não logra vingar em favor do procedimento acanhado dos primeiros edificadores, que erguiam as suas casas à direita e à esquerda, acima e abaixo, com tanto cunho de estabilidade no detalhe quão pequena preocupação de ordem $e$ de progresso no conjunto. ${ }^{89}$

O Novo Arrabalde implicaria assim não apenas na construção material de um novo espaço, mas, sim, de uma sociabilidade diversa do "viver acanhado" da cidade tradicional. Essa formulação seria constante nos relatórios e projetos posteriores.

\footnotetext{
86 Cf. E. Said, Orientalismo: o Oriente como invenção do Ocidente, 1990 [1978].

${ }^{87}$ F. Saturnino R. de Brito, Saneamento de Recife, in Obras completas de Saturnino de Brito, v.8, 1943, p.21-33 passim.

88 Ibidem, p.09; grifos nossos.

89 Idem, Melhoramentos de Vitória, Espírito Santo [1896]. In Obras Completas de Saturnino de Brito, v. 5, 1943, p.15; grifos nossos.
} 
Como formularia em seu Tracé Sanitaire, as cidades brasileiras ainda viviam na fase do fazer-se ao acaso, ${ }^{90}$ sem ou com pequena preocupação de "ordem" e de "progresso" - preocupações que implicavam plano (delineado sob o imperativo do traçado sanitário).

90 À maneira de Comte, como discute Carlos de Andrade, Brito diria que haveria três fases que caracterizam o desenvolvimento das cidades: a primeira é a "formation au hasard des premiers éléments d'un village ou d'u faubourg"; a segunda é o "développement sans plan général, sans programme précis, suivant des plans partiels, d'occasion ou de fortune, esquissés para lês proprietaires interesses, ou par les administrations locales, généralement mal conseillées"; por fim, a terceira seria o "regime de l'élaboration systèmatique de plans d'ensemble bien coordonnées pour l'extension future et pour la formation des villes nouvelles", cf. Saturnino de Brito, Tracé sanitaire des villes, op. cit., p.147. 
CAPÍTULO 3

\section{A ARTE QUE LHE FALTA}

Legitimações do campo disciplinar do urbanismo 


\begin{abstract}
"Les besoins de la vie moderne ne peuvent plus s'adapter aux plans irréguliers de la plupart des villes anciennes"

Francisco Saturnino de Brito, Le tracé sanitaire des villes, 1916.
\end{abstract}

A mudança da capital de Minas Gerais foi assumida, desde meados do século XIX pelo menos, como uma tarefa necessária para a modernização do estado, marco simbólico e material da superação - que se pretendia definitiva - dos entraves atávicos do período colonial e, depois, imperial. Ouro Preto, a antiga e próspera Vila Rica, havia muito não era considerada uma alternativa viável para ser a sede do poder político-administrativo. Como resumiria o jornal "A Ordem”, em edição de 19 de julho de 1890, a propaganda contra a então e ainda capital advertia tanto para a falta de condições higiênicas necessárias e para a "péssima posição topográfica" quanto para a situação geográfica que dificultava a ação governamental de administração do território do estado e desenvolvimento dos interesses públicos e particulares. Ademais, não haveria nem área para expansão urbana nem condições para suscitar uma rica vida social urbana que uma capital moderna requeria. ${ }^{1}$

Tanto que, num derradeiro esforço para manter a condição de Ouro Preto como capital, constituiu-se uma Comissão de Melhoramentos, em 1891 - em meio ao recrudescimento das discussões nos jornais e na assembléia legislativa estadual sobre as localidades mais propícias para receber a nova capital -, para modernizar a antiga cidade, com retificação de traçados viários, construção de boulevard, organização de um serviço de transporte público com bondes e delimitação de áreas para expansão urbana, em especial no Morro do Cruzeiro, onde, projetava-se, poderia se criar uma nova e moderna cidade para mais de 50 mil habitantes ligada à existente por um viaduto de ferro. Medidas duramente criticadas pelos grupos mudancistas, que apontavam o contínuo sorvedouro de recursos que a capital

\footnotetext{
1 A citação de "A Ordem" é derivada de Caion M. Natal, Ouro Preto: a construção de uma cidade histórica,
} 1891-1913, p.15-16. 
representava, sem nada produzir depois do fim da atividade mineira. Tais melhoramentos tratavam-se de um "embelezamento impraticável e improfícuo", pois não se iria reverter a imagem de decadência e de desolação de que fora impregnada a cidade desde o início do século XIX por meio do relato de vários viajantes, como John Mawe, Saint-Hilaire e, já na segunda metade do Oitocentos, Richard Burton. ${ }^{2}$ Os mesmos recursos projetados poderiam ser melhor empregados na construção da nova capital, defendiam muitos publicistas, como os de "O Contemporâneo", de Sabará. ${ }^{3}$

A escalada de decisões que levariam à criação da Comissão Construtora da nova capital poria por terra de vez tais esforços. Obras ficaram pela metade, outras tantas nem mesmo sairiam do papel. ${ }^{4} \mathrm{O}$ prolongamento da Estrada de Ferro D. Pedro II até Ouro Preto (concluído em 1889), obra de complicada logística e solução técnica dirigida pelo engenheiro Miguel Burnier, também pouco servira para romper com a leitura de que a capital era mal localizada geograficamente para ser o centro simbólico e político do estado.

A isso se somavam as leituras de decadentismo, de atraso e de desordem que caracterizavam várias cidades coloniais do ciclo do ouro, em especial Ouro Preto. O projeto mudancista apresentado pelo Padre Agostinho Paraíso à Assembléia Provincial em 1867 fundava-se na leitura da decadência e do caráter parasitário de uma capital que nada produzia (em tom jocoso, muitos afirmavam que nem mesmo suas hortaliças), e.g. ${ }^{5} \mathrm{O}$ terreno acidentado e montanhoso apenas agravava esse conjunto de representações.

Leituras que perdurariam ao longo das primeiras décadas do século XX, como se percebe na monumental história de Belo Horizonte construída por Abílio Barreto, ainda hoje uma fonte fundamental (que compila e organiza diversos

\footnotetext{
2 Esses relatos ainda impressionariam vivamente os estudos de John Bury sobre a arte e arquitetura colonial de Minas Gerais em meados do século XX, cf. J. Bury, Arquitetura e Arte no Brasil colonial, 2006. Manuel Bandeira registrou essa mudança de percepção - da "decepção ante a decadência do lugar" no século XIX à sensibilidade à beleza pitoresca no século XX, cf. Guia de Ouro Preto, 1938, p.34.

${ }^{3}$ Mudança da Capital, O Contemporâneo, Sabará, 29 jun. 1890, p.04 apud Abílio Barreto, Belo Horizonte: memória histórica e descritiva, vol. I, história antiga, 1996, p.300.

${ }^{4}$ Caion M. Natal, op. cit., p.37-58.

5 Abílio Barreto, op. cit., vol. I, p.288-291; o projeto receberia parecer favorável no ano seguinte, mas seria vetado em seguida pelo presidente da província (veto endossado em votação apertada, dias depois), cf. Ibidem, p.292-295.
} 
documentos originais, alguns já perdidos, dos quais esta tese se vale enormemente) para os estudos sobre a cidade. Com claro viés evolucionista, como discute a historiadora Heliana Salgueiro, Barreto procurava demonstrar que a necessidade de mudança da capital estava inscrita na própria história da capitania de Minas Gerais (quando, em 1720, foi separada da de São Paulo e se cogitou pela primeira vez da mudança). ${ }^{6}$ Ouro Preto, embora histórica e venerável para o historiador que publicava o primeiro volume (dedicado ao que chama de "história antiga") da sua obra no final da década de 1920, era a capital velha, com defeitos insanáveis e de péssima posição para ser sede de uma província que precisava progredir.

Assim, nos embates que levariam à criação de Belo Horizonte se entrecruzam várias questões relacionadas: as disputas e os diversos interesses políticos e econômicos de grupos regionais, as leituras e proposições de uma emergente cultura técnica moderna no Brasil, por meio sobremodo da ação dos engenheiros, e as formulações - que revelam representações - sobre o território, sobre os núcleos urbanos existentes e as suas histórias. Mais ainda, Belo Horizonte significou um ponto de convergência e de discussão (que perduraria ainda nas primeiras décadas do século XX), um marco enfim, na formação do campo disciplinar do urbanismo moderno no Brasil, embora ainda não fosse assim nomeado.

Como já se observou, o plano de Belo Horizonte constituiu-se uma suma dos conhecimentos técnicos sobre as cidades e sobre o território no Brasil do final do século $\mathrm{XIX}^{7}$ que se embebeu claramente nas leituras higienistas e na formação politécnica e positivista dos engenheiros. Além do plano em si, o longo relatório final, que será discutido a seguir, preparado pelo engenheiro Aarão Reis para definir a localidade que receberia a nova capital, é exemplar dessa confluência que marca a emergência do urbanismo moderno. ${ }^{8}$

Exemplar também de uma importante inflexão que vinha se processando na segunda metade do século XIX: o lugar social de proeminência do engenheiro, no

\footnotetext{
${ }^{6}$ Heliana A. Salgueiro, A “volta” da história, in A. Barreto, op. cit., vol. I, 1996, p.35-39.

7 Marco Aurélio Gomes e Fábio Lima, Pensamento e prática urbanística em Belo Horizonte, 18951961, in C. Leme, Urbanismo no Brasil, 1895-1965, 1999, p.120.

${ }^{8}$ D. Calabi, Storia dell'urbanistica europea, 2000; M. S. Bresciani, História e historiografia das cidades, um percurso, In M. C. Freitas (org.), Historiografia brasileira em perspectiva, 1998, p.244; Carlos de Andrade, A peste e o plano: o urbanismo sanitarista do Eng. Saturnino de Brito, 1992; e F. Béguin, As maquinarias inglesas do conforto, Espaços e Debates, 1991 [1977].
} 
lugar do médico, na elaboração e condução dos relatórios de análise dos espaços urbanos e dos planos de reforma, de expansão ou mesmo criação, como é o caso, de cidades, enfim, nos processos de modernização urbana. A composição (definida em lei adicional à constituição estadual de 1893) da Comissão de estudos das localidades indicadas para a nova capital diz muito dessa inflexão: Aarão Reis, nomeado engenheiro-chefe, designou mais cinco engenheiros, um para cada localidade a ser estudada, e um médico, além do pessoal de apoio técnico e administrativo. ${ }^{9} \mathrm{O}$ médico funcionava como um consultor, pelo que se depreende do relatório final de Aarão Reis. Coligia dados climáticos, fazia apanhados estatísticos (alguns baseados apenas nas informações orais) e observava, dentro da longa tradição mesológica, o território. Os dados principais, seriados, mesmo aqueles que interessavam diretamente ao saber médico, eram compulsados pelos engenheiros e auxiliares. Ao que tudo indica, ao contrário dos engenheiros, que residiram e trabalharam praticamente de maneira ininterrupta em cada localidade por cinco meses, o médico apenas as visitava, por vezes muito brevemente.

Um breve parêntese: essa relação assimétrica entre a atuação de engenheiros e médicos foi, pode-se especular, um fator a mais que pesou nos debates legislativos que articularam a mudança da Várzea do Marçal para o arraial de Belo Horizonte. É certo que a avaliação final de Aarão Reis pendeu para a primeira, mas apenas com leve vantagem sobre a segunda.

Entre Várzea do Marçal e o Belo Horizonte é difícil a escolha. Em ambas, a nova cidade poderá desenvolver-se em ótimas condições topográficas; em ambas, é facílimo o abastecimento de água e a instalação dos esgotos, ambas oferecem excelentes condições para as edificações e a construção em geral, e se, na atualidade, a Várzea do Marçal representa melhor o centro de gravidade do Estado e acha-se já ligada, por meios rápidos e fáceis de comunicação com todas as zonas, daqui a algumas dezenas de anos Belo Horizonte melhor o representará, decerto, e mais diretamente ligada ficará a todos os pontos do vasto território mineiro.

É, porém, de notar que na Várzea do Marçal há muito maior área de terrenos devolutos dentro no próprio perímetro da futura cidade, e a execução das obras indispensáveis à instalação desta exigirá menor dispêndio, acrescendo que, em Belo Horizonte, será

\footnotetext{
${ }^{9}$ Os membros da Comissão eram: eng. José Carvalho de Almeida (em Várzea do Marçal), eng. Samuel Gomes Pereira (em Belo Horizonte), eng. Manuel da Silva Couto (em Barbacena), eng. Eugênio de Barros Raja Gabaglia (em Juiz de Fora), eng. Luis Martinho de Morais (em Paraúna) e o médico José Ricardo Pires de Almeida, cf. A. Barreto, op. cit., vol. I, p.334-343.
} 
mister, desde logo, construir um ramal férreo de 15 quilômetros, ligando-a à Estrada de Ferro Central do Brasil. ${ }^{10}$

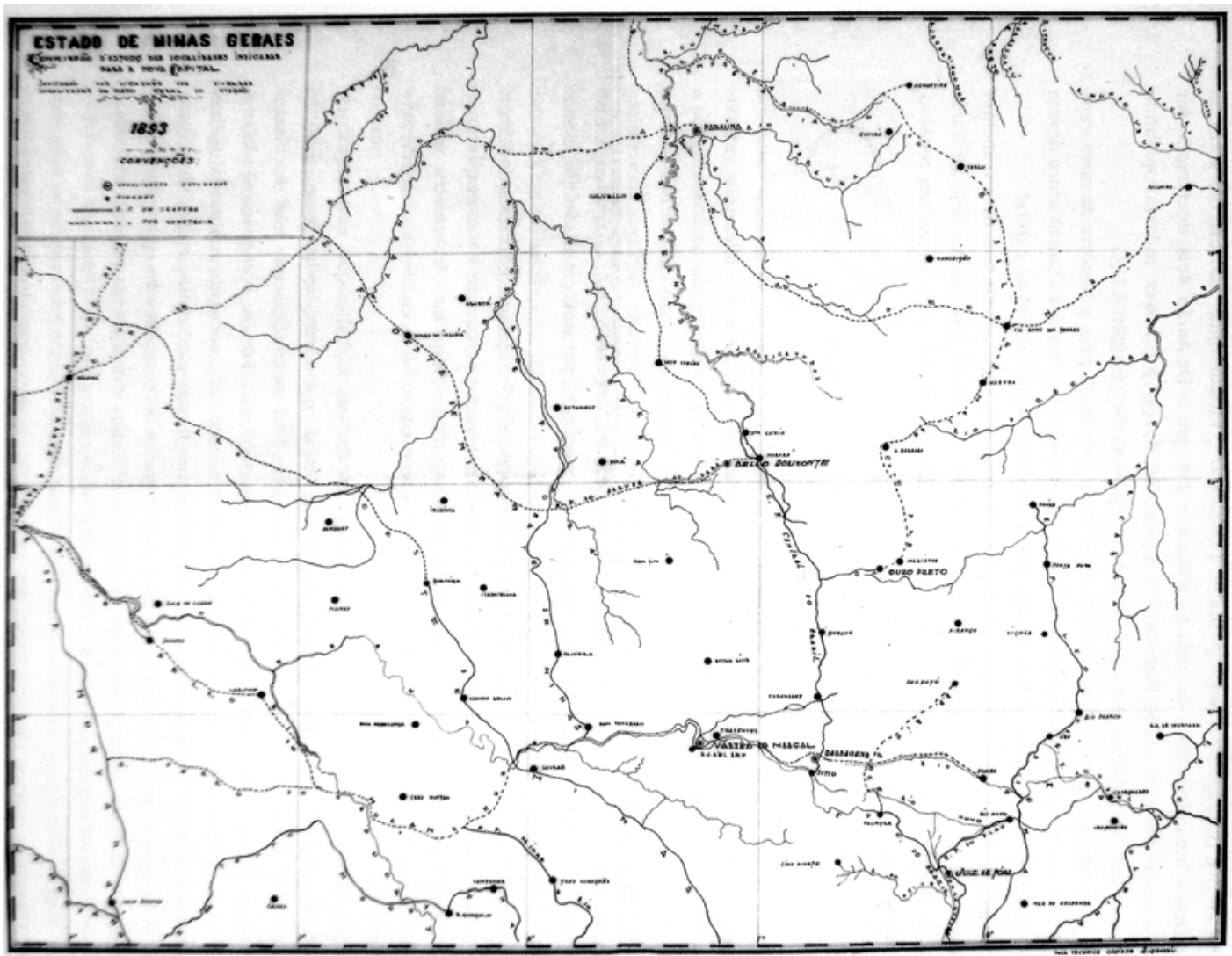

Figura 3.01: Mapa de Minas Gerais com as cinco localidades estudadas pela Comissão. Fonte: A. Barreto, Belo Horizonte, 1996, v.1, p.344.

O médico Pires de Almeida apontara que Belo Horizonte seria mais salubre do que a Várzea do Marçal. Aarão Reis, a partir dos dados apresentados, inverteria essa classificação. Essa questão estava longe de ser de somenos importância para intelectuais e técnicos formados ao longo do século XIX. De maneira geral, Aarão Reis, embora advertisse para a impossibilidade de estabelecer generalizações com os dados colhidos em apenas cinco meses de trabalho (conquanto em condições uniformes, por aparelhos aferidos previamente e de fabricação idêntica), apontou que se podia inferir e corroborar o juízo generalizado no Brasil e entre os visitantes estrangeiros acerca da "excelência do clima mineiro, sobretudo da zona que ocupa o grande planalto da Mantiqueira"; especialmente em Barbacena, na Várzea e em Belo

${ }^{10}$ A. Reis, Comissão de Estudos das localidades indicadas para a nova capital, relatório apresentado à S. Ex. Dr. Afonso Pena, presidente do estado de MG..., janeiro a maio de 1893, Rio de Janeiro: Imprensa Oficial, 1893 [esse é o item $4^{\circ}$ da Conclusão Geral dos estudos], in A. Barreto, op. cit., vol. I, p.396. 
Horizonte, o clima concorreria "eficaz e poderosamente" para as condições gerais de salubridade. ${ }^{11}$

Os dados do relatório sobre o clima seriam tomados como um elemento de legitimação da escolha da localidade de Belo Horizonte nos debates legislativos, em julho de 1893. Por um lado, avalizou-se o trabalho do médico - quando afirmou a melhor salubridade de Belo Horizonte em relação à Várzea. Por outro, em relação às anotações sobre a possibilidade de o bócio ser endêmico na região, alguns congressistas ironizariam o fato de Pires de Almeida ter passado pelo arraial pouco mais de 24 horas; lembraram ademais que a "idéia do bócio" fora mobilizada em artigos de periódicos de Ouro Preto como parte da propaganda anti-mudancista. Os dados apresentados pelo médico não serviam para configurar uma particularidade endêmica e foram considerados estatisticamente irrelevantes ${ }^{12}$ - o que de fato eram, deve-se dizer.

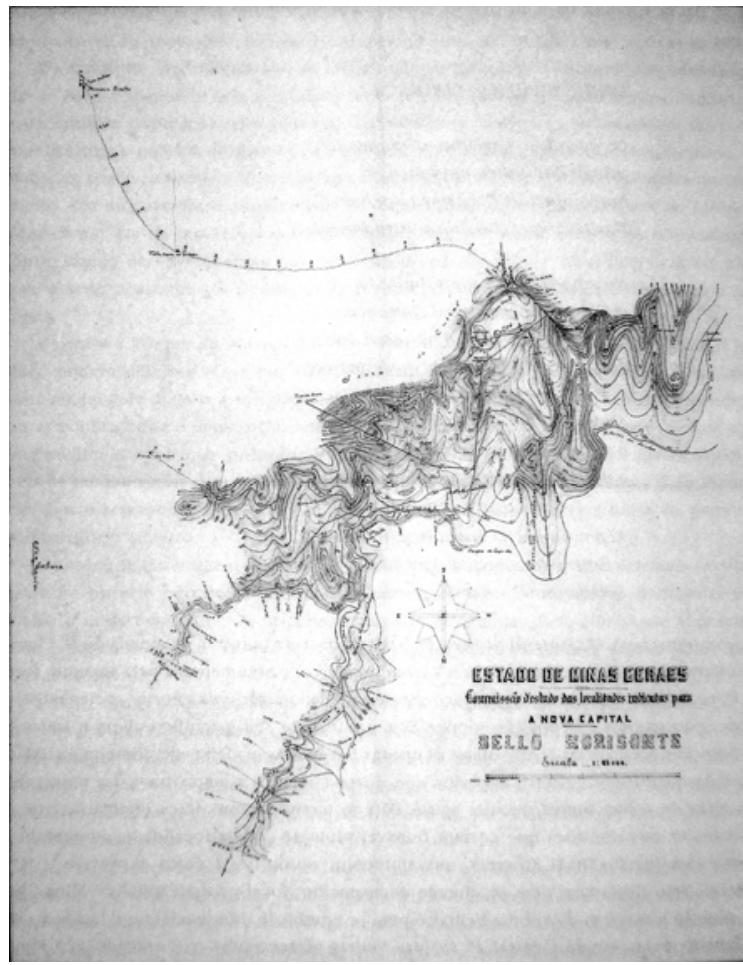

Figura 3.02: planta do arraial de Belo Horizonte, desenhada pela Comissão em 1893.

Fonte: A. Barreto, Belo Horizonte, 1996, v.1, p.398.

11 Ibidem, p.363-365, 372.

12 Extratos das discussões de várias sessões, que levariam à escolha de Belo Horizonte, podem ser lidas no cap. XV do livro de A. Barreto, op. cit., vol. I, p. 404-429. 
Ressalte-se esse aspecto para que não se incorra no equívoco de que tenha havido um simples deslocamento entre a decisão técnica e a decisão política, como se a primeira fosse deixada de lado. A elaboração técnica, embora se propusesse neutra e afastada de qualquer interesse, como o faria Reis na introdução ao relatório, ${ }^{13}$ foi mobilizada decisivamente nos embates e no encaminhamento das decisões políticas travadas mais diretamente no âmbito do legislativo estadual. Conformaria um argumento fundamental para legitimar decisões em meio às discussões e a outros argumentos.

Enfim, sobre o que não restava dúvida era a impropriedade de uma cidade como a antiga Vila Rica continuar a ser a capital. Tanto que os relatórios da Comissão de estudos das localidades e os textos da Comissão Construtora praticamente não abordaram, diretamente, esse tema. Em muitos aspectos, pode-se dizer que a batalha simbólica pela nova capital - nascida moderna, sob os imperativos da higiene, da estética neoclássica e da fluidez da circulação e das comunicações $^{14}$ - já estava ganha, em detrimento das velhas vilas e arraias coloniais. Quase um século de leituras reforçando a imagem de decadência, de atraso, de irregularidade conformariam um fundo-comum que, depois, seria importante para construir representações úteis aos projetos de modernização urbana.

\footnotetext{
13 "Não sendo natural de Minas Gerais, nem tendo aí o mínimo interesse pessoal, direto ou indireto, e animado, por outro lado, dos sentimentos a que já me referi, encontrei-me e encontro-me, felizmente, no exame e estudo deste assunto, com a mais perfeita isenção de ânimo e de espírito, sem predileções prévias e, mesmo agora, sem paixões adquiridas, fazendo os mais ardentes votos para que o futuro confirme a escolha que for decretada"; isso levaria Aarão Reis a abrir mão, inclusive, da colaboração dos profissionais mineiros, “a cuja cooperação já tenho aliás devido, em outras comissões, os melhores serviços" (A. Reis, Comissão de Estudos das localidades indicadas para a nova capital, relatório apresentado à S. Ex. Dr. Afonso Pena, presidente do estado de MG, janeiro a maio de 1893, Rio de Janeiro: Imprensa Oficial, 1893, in A. Barreto, op. cit., vol. I, p.345-46).

${ }^{14}$ Heliana A. Salgueiro, O pensamento francês na fundação de Belo Horizonte, in H. A. Salgueiro (org.), Cidades capitais do século XIX, 2001c; Marco Aurélio Gomes e Fábio Lima, op. cit., p.120-21; e Berenice Guimarães, A concepção e o projeto de Belo Horizonte: a utopia de Aarão Reis, in L. C. Ribeiro e R. Pechman, Cidade, povo e nação: gênese do urbanismo moderno, 1996, p.123-140.
} 


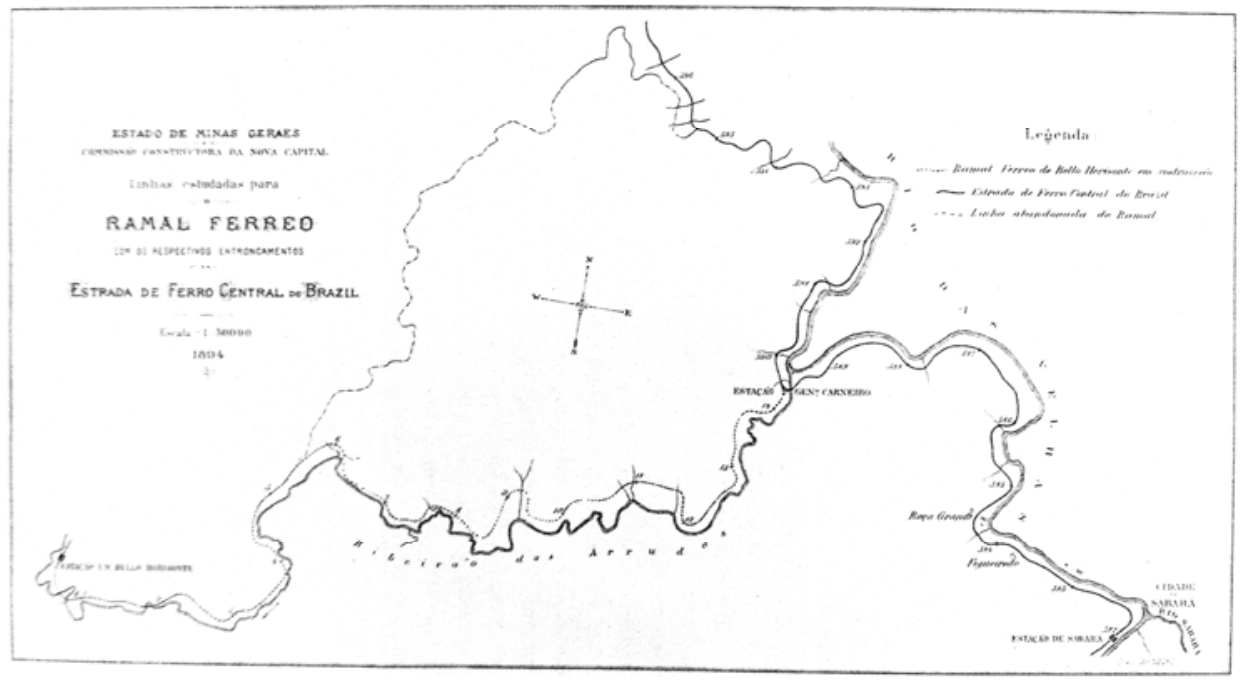

Figura 3.03: linhas estudadas para o ramal férreo, e respectivos entrocamentos, entre Belo Horizonte e Sabará. Fonte: A. Barreto, Belo Horizonte, 1996, v.2, p.66.

O presente capítulo parte assim da leitura das peças técnicas relacionadas ao processo de elaboração do plano de Belo Horizonte para inquirir como o tema da cidade colonial seria mobilizado, instrumentalizado e problematizado como parte do processo de legitimação do campo disciplinar do urbanismo no Brasil. Afinal, é cada vez mais claro para a historiografia brasileira que o saber urbanístico, nesse período de formação (e não somente), não escaparia do crivo das formulações do pensamento histórico-social do país (sobre a formação racial, a influência do clima e do meio, o papel do elemento "primitivo", etc.) e das suas construções ideológicas, cujos temas seriam rebatidos na própria episteme da disciplina (pretensamente neutra e científica) e "na reflexão sobre o processo de urbanização e modernização do país". ${ }^{15}$ Saber, portanto, que seria atravessado pelas mais variadas hipóteses de formação do Brasil, nas quais a construção do passado colonial e, conseqüentemente, dos significados (das formas) da cidade, é peça central.

Saber que, em seus textos inauguradores, como na Teoría General de la Urbanización (1867), de Ildefonso Cerda, se faria também como oposição entre ordem e desordem, no balanço e avaliação entre uma cidade em negativo (com seus defeitos) e outra em positivo (o modelo espacial ordenado, que se vislumbra no plano). Inscreve-se assim em sua episteme a tarefa de análise sincrônica e diacrônica

15 José Lira, O Urbanismo e o seu outro: raça, cultura e cidade no Brasil (1920-1945), Revista Brasileira de Estudos Urbanos e Regionais 1999. 
da cidade - o que levaria, inevitavelmente, a avaliar como anacrônicas as cidades antigas segundo a ótica da necessidade de circulação e comunicação modernas. ${ }^{16}$

\section{1 a primeira cidade da América do Sul}

Foi citado acima o trecho final do relatório da Comissão de estudos das localidades, quando Aarão Reis sopesa e se inclina por Várzea do Marçal como o lugar mais adequado para receber a nova capital. É significativo também outro trecho (o $5^{\circ}$ item) quando afirmaria que

(...) é preferível que a nova capital seja edificada na Várzea do Marçal, onde o Estado de Minas Gerais poderá - mediante projeto organizado com competência e baseado em sérios e cuidadosos estudos definitivos - erguer, dentro de três anos, e sem exagerados ônus para seus cofres públicos, a primeira cidade da América do Sul, dominando de cerca de $1.000 \mathrm{~m}$ de altitude todo o vasto planalto brasileiro. ${ }^{17}$

Significativo mas lacunar. De onde adviria essa afirmação de que a nova capital a ser construída seria a primeira cidade da América do Sul? É difícil até especular. Não parece ser peça de retórica, força de expressão para inflar o discurso e ganhar uma assembléia e seus ouvintes - embora se soubesse que o relatório seria escrutinado e avaliado para a deliberação e conseqüente escolha política da nova capital. Não se pode alegar ignorância de seu autor tampouco. Aarão Reis, como muitos de seus pares, a exemplo de André Rebouças e Saturnino de Brito, tinha conhecimento vasto, livresco por vezes, da produção científica e técnica da época. O relatório de Reis está repleto de citações aos técnicos franceses, e.g., para convalidar os dados e as conclusões acerca das soluções para o saneamento e para o abastecimento de água.

Da mesma forma, durante a elaboração do projeto, Aarão Reis solicitaria inúmeras publicações técnicas estrangeiras para manter a comissão atualizada. Escreveria ainda para o ministro Plenipotenciário do Brasil na Argentina solicitando os dados relativos às grandes cidades do país vizinho, enfim tudo que fosse útil para

${ }^{16}$ F. Choay, A regra e o modelo, 1985, p.266-275.

17 A. Reis, Comissão de Estudos das localidades indicadas para a nova capital, op. cit., in A. Barreto, op. cit., vol. I, p.396. 
informar o projeto, desde plantas, perfis, vistas, memoriais e estatísticas, até as normas municipais, de polícia, de higiene e sanitárias. Deriva daí também o interesse pelo projeto de La Plata (concebida como a capital da Província de Buenos Aires, em 1882), com o qual compartiria a estrutura básica quadriculada cortada por diagonais e encerrada por um boulevard circular, além das grandes áreas verdes como parte da concepção. ${ }^{18}$

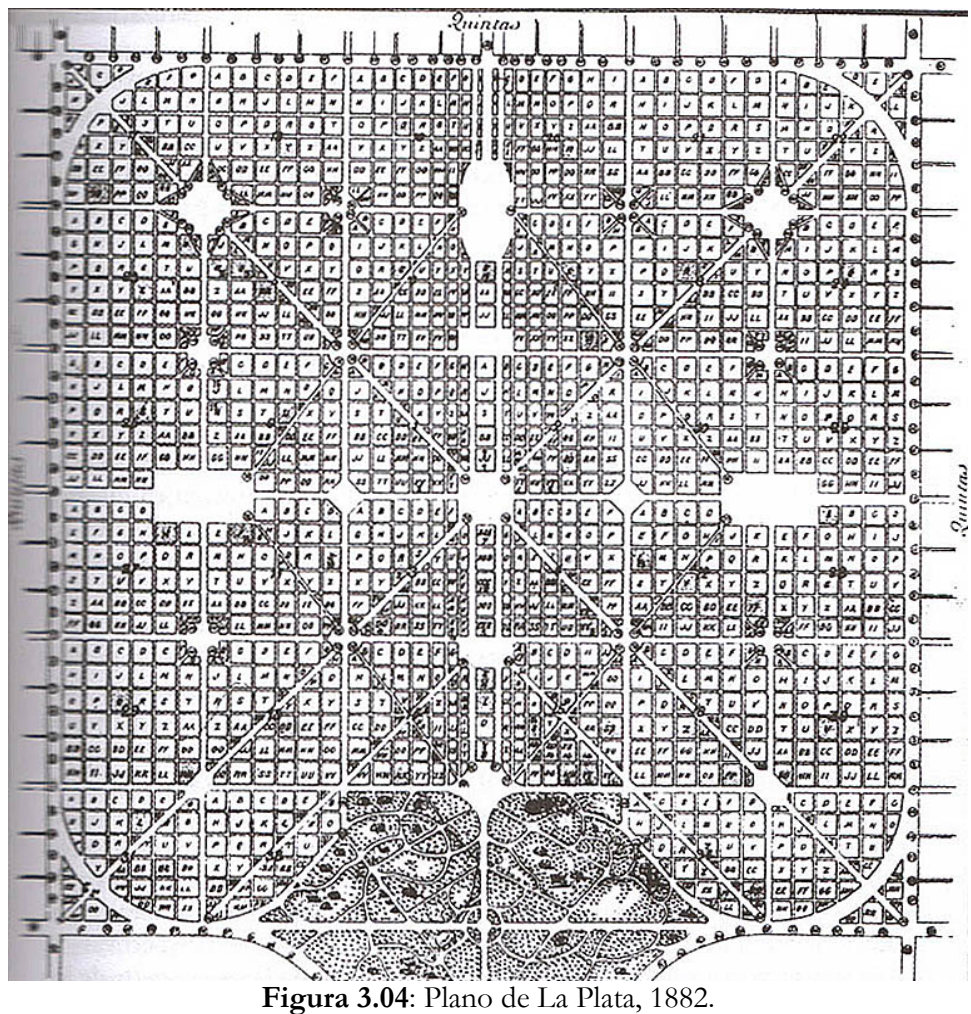

Fonte: H. Capel, La Morfología de las ciudades, 2002.

Outrossim, é difícil pensar que Reis não conhecesse a proposta de criação de Teresina ou mesmo de Aracaju. Reis fez parte de uma geração de técnicos que ajudou a construir uma compreensão abrangente sobre o território do Império a partir da discussão de questões que seriam configuradas como problemas de interesse nacionais, a exemplo do fenômeno das secas nas chamadas províncias do Norte e da necessidade de articulação de um sistema de comunicação e circulação integrado. Não à toa, Aarão Reis seria inspetor chefe da Inspetoria de Obras Contras as Secas

\footnotetext{
18 Marco Aurélio Gomes e Fábio Lima, op. cit., p.121.
} 
nos anos 1910. ${ }^{19}$ Eventos desse porte não lhes eram estranhos, principalmente considerando que a fundação da nova capital da então Província do Piauí, em 1852, deu-se a partir de argumentação semelhante: a situação geográfica de Oeiras, a antiga capital, era considerada um obstáculo à modernização. Situada em região de terras de pouca fertilidade e, principalmente, distante do rio Parnaíba, principal escoadouro do território, Oeiras fora construída no contexto de esforço para aumentar a autoridade da Coroa e o controle sobre a colônia no início do século XVIII e, assim, possibilitar a ligação terrestre pelo interior entre as capitais dos estados do Brasil (Salvador) e do Maranhão e Grão-Pará (São Luís). ${ }^{20}$ Teresina, a nova capital, deveria ser melhor localizada para facilitar a circulação da produção e para possibilitar o controle administrativo da província, cujas necessidades não estavam mais atreladas ao antigo sistema colonial. ${ }^{21}$

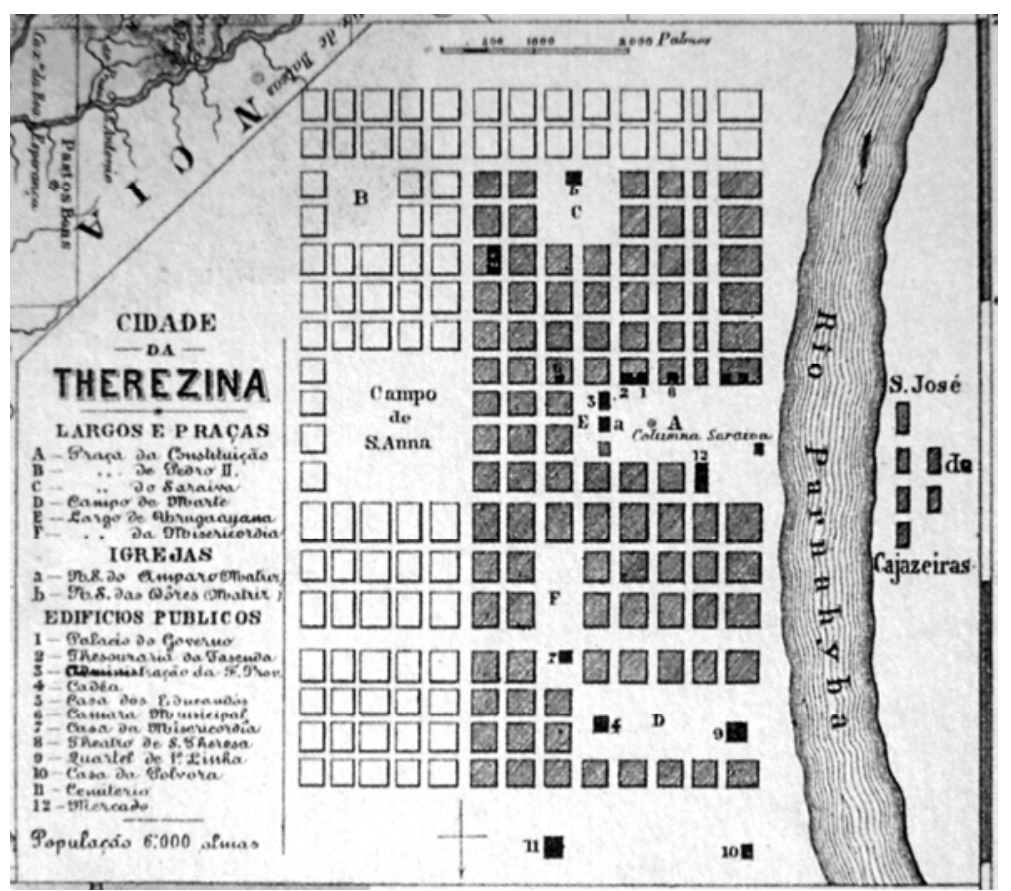

Figura 3.04: esquema do mapa de Teresina-PI

Fonte: Cândido M. de Almeida, Atlas do Império do Brasil, 2000 [1868]

19 Cf. George Dantas, Angela Ferreira e Hélio Farias, Pensar e agir sobre o território das secas: planejamento e cultura técnica no Brasil (1870-1920), Vivência, 2008.

${ }^{20}$ Roberta M. Delson, Novas vilas para o Brasil-Colônia: planejamento espacial e social no século XVIII, 1997 [1979], p. 17-24.

${ }^{21}$ Mauricio de Abreu, $\mathrm{O}$ estudo geográfico da cidade no Brasil, in Os caminhos da reflexão sobre a cidade e o urbano, 1994. 


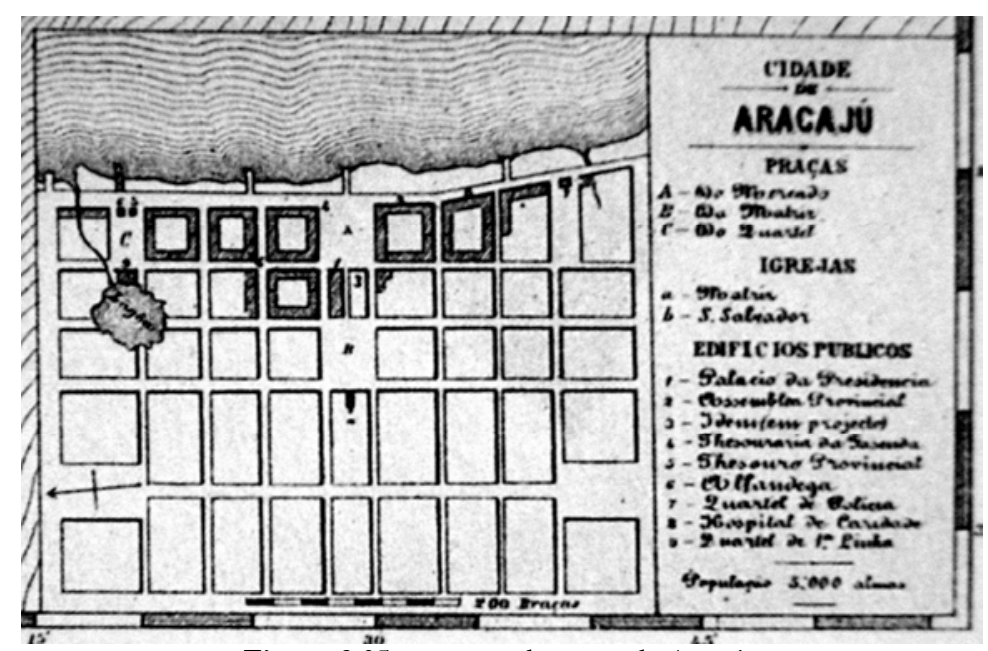

Figura 3.05: esquema do mapa de Aracaju

Fonte: Cândido M. de Almeida, Atlas do Império do Brasil, 2000 [1868]

Para a fundação de Aracaju, em 1855, o "fator geográfico" seria também preponderante. Os antigos portos de Capivaras, Pedreiras e Porto das Redes e suas respectivas pequenas estruturas urbanas que serviam como "cidades de fundo de baía", como postos de passagem que articulavam a produção do interior à distribuição no litoral, eram consideradas incompatíveis ao desenvolvimento da navegação e ao uso dos vapores de maior calado. No lugar de São Cristóvão, distante mais de $20 \mathrm{~km}$ do litoral, antiga capital provincial de uma rede urbana que gravitava em função da província da Bahia, propôs-se (com risco do engenheiro Sebastião Basílio Pirro) uma trama regular em rígido tabuleiro de xadrez inicial que pretendia ser a cabeça de uma nova articulação territorial que marcasse a autonomia de Sergipe. $^{22}$

Havia um fundo-comum de argumentação, certamente, no que diz respeito ao papel que uma cidade capital deveria desempenhar - papel que estava relacionado a uma leitura da estrutura econômica e urbana do sistema colonial que, defendia-se, estava havia muito superado. No caso de Belo Horizonte, tal argumentação acirravase em oposição a um atraso que tinha uma clara expressão material na estrutura e na paisagem urbanas de Ouro Preto.

Assim, por que escrever e anunciar a nova capital a ser construída - em um momento em que o projeto ainda seria elaborado - como a primeira cidade da

22 Fernando Porto, A cidade do Aracaju 1855/1865, 1991 [1945], p.13-17; W. Santos e Maria Vargas, Apropriações na construção do urbano na cidade de Aracaju/SE, Scientia Plena, 2007. 
América do Sul? Havia, antes de mais nada, a consciência de se estar diante de uma tarefa nova, com nenhum ou poucos parâmetros que pudessem servir de ponto de partida para a reflexão; havia também a consciência do vulto e do significado da tarefa, aspecto já ressaltado pela historiografia sobre o tema, da construção de uma cidade que não apenas externasse os valores do regime republicano, mas que, principalmente, pudesse se tornar um farol a apontar o caminho para a modernização do país.

Pode-se especular que havia também aí uma leitura, derivada do fundocomum da forte influência positivista dos engenheiros politécnicos brasileiros, que, anos depois, levaria à formulação de Saturnino de Brito acerca das fases de crescimento do organismo urbano (derivadas, de certo modo, dos três estados da evolução intelectual da humanidade da filosofia comteana). ${ }^{23}$ Belo Horizonte significaria assim, pode-se inferir (em retrospecto de Brito para Reis), naquele momento, o ingresso definitivo na terceira fase - uma cidade concebida segundo um plano geral, "a imagem utópica da cidade salubre", que teria deixado de lado o lento processo de expansão das cidades coloniais brasileiras, dominadas pelo acaso (a primeira fase que, ainda assim, consolidaria a situação fundiária), e o predomínio dos interesses particulares, da especulação (a segunda fase).

Mas, ilações à parte, o sentido permanece: a nova capital apontaria para um novo país, uma possibilidade de articular o território vasto da nação, por meio de uma nova maneira de pensar a cidade e sua relação com a região. Idealmente, não consolidaria um caminho existente, um interesse de exploração imediato. A cidade capital serviria a um projeto de poder que é também simbólico, por óbvio (com sua centralidade, sua arquitetura oficial monumental, seu desenho urbano que se impõe sobre a topografia, etc.). ${ }^{24}$

Das considerações que levariam, por fim, à escolha do antigo sítio de Curral d'El Rey para erguer a nova capital, deve-se fazer pelo menos mais três considerações que interessam diretamente ao recorte de pesquisa e leitura aqui proposto.

\footnotetext{
23 Cf. Carlos de Andrade, A peste e o plano: o urbanismo sanitarista do eng. Saturnino de Brito, 1992, p.199201; F. R. Saturnino de Brito, Le tracé sanitaire des villes, 1916, p. 41-43.

${ }^{24}$ A. Picon, Racionalidade técnica e utopia: a gênese da Haussmannização, In Cidades capitais do século XIX, 2001; Bernard Lepetit, Das capitais às praças centrais. Mobilidade e centralidade no pensamento econômico francês, in Cidades capitais do século XIX, 2001.
} 
Primeiro, o rigor da análise técnica, que procurava ponderar e sopesar com minúcias os critérios técnicos e econômicos, não deixaria de estabelecer apreciações estéticas da paisagem, marcadas por certa noção do pitoresco e pelas imagens que se vinham sobrepondo à leitura das cidades coloniais havia décadas. Veja-se, e.g., as considerações sobre a cidade de Barbacena, em relação à posição geográfica e condições topográficas:

Situada no planalto da Mantiqueira, (...), é incontestavelmente um dos pontos mais apraziveis, não só do Estado Mineiro, porém mesmo de todo o Brasil.

O vasto e soberbo horizonte que, do cimo do seu Monte Mário, se descortina, em todo o esplendor de uma atmosfera limpida e brilhante, para todas as direções; os maravilhosos efeitos de cambiante perspectiva que se gozam do alto de suas sucessivas colinas; o relevo variado e multiforme de sua topografia; a pureza do ar que se respira; o encanto de sua solidão em meio das campinas onduladas que a circundam; os cursos de água que serpeiam no fundo dos seus vales; o panorama que já oferecem alguns elegantes prédios espalhados pelos cabeços dos seus morros (...). ${ }^{25}$

E Aarão Reis continuava a sua descrição que evoca, ainda que sem pretensões literárias, o encantamento dos viajantes com a paisagem. Não havia, certamente, a perícia de uma Maria Graham, cujas narrativas eram marcadas por suas habilidades como desenhista, mas, sim, a tentativa de fixar um quadro, transmitir sensações táteis e visuais para delimitar uma paisagem de interesse pitoresco. Os cronistas lembrariam dos passeios de Reis pelo sítio na época em que traçava a planta de Belo Horizonte. ${ }^{26}$ Ao mesmo tempo, e como muitos viajantes artistas fizeram, essa é uma beleza que se via a partir do núcleo urbano (e não enquadrando o núcleo urbano), olhando para o sítio natural circundante; ou mesmo, é uma beleza que se percebia à distância. Barbacena, no máximo, seria local de repouso, uma cidade para retiro, com sua "tranqüilidade de uma vida descuidosa e calma, que permite seu afastamento dos grandes centros agitados do país" ${ }^{27}$ Um quadro que só funcionaria se mantido estático para fruição estética; o aumento populacional decorrente da implantação administrativa de uma capital facilmente romperia com tal harmonia. Percebe-se

25 A. Reis, Comissão de Estudos das localidades indicadas para a nova capital, op. cit., in A. Barreto, op. cit., vol. I, p.351; grifos nossos.

${ }^{26}$ Heliana A. Salgueiro, O Pensamento francês na fundação de Belo Horizonte, op. cit., p.157-158.

27 A. Reis, Comissão de Estudos das localidades indicadas para a nova capital, op. cit., in A. Barreto, op. cit., vol. I, p.351. 
como, no contrapelo, Aarão Reis construía sua leitura da cidade colonial, ainda que não diretamente explicitada. As citações que se seguem são longas mas instrutivas para entender as limitações que apareciam aos olhos do engenheiro:

Constituída, porém, totalmente, quer na parte já ocupada pela atual cidade, quer na que, em seus arredores, pode ser aproveitada para o desenvolvimento desta, por interminável sucessão de morros, separados por insignificantes córregos e oferecendo, em todos os sentidos, fortes declividades que se elevam até $15 \%$, não permite esta localidade, pela irregularidade de sua caprichosa topografia e esquisita configuração do terreno, a edificação de uma grande cidade em boas condições técnicas e higiênicas.

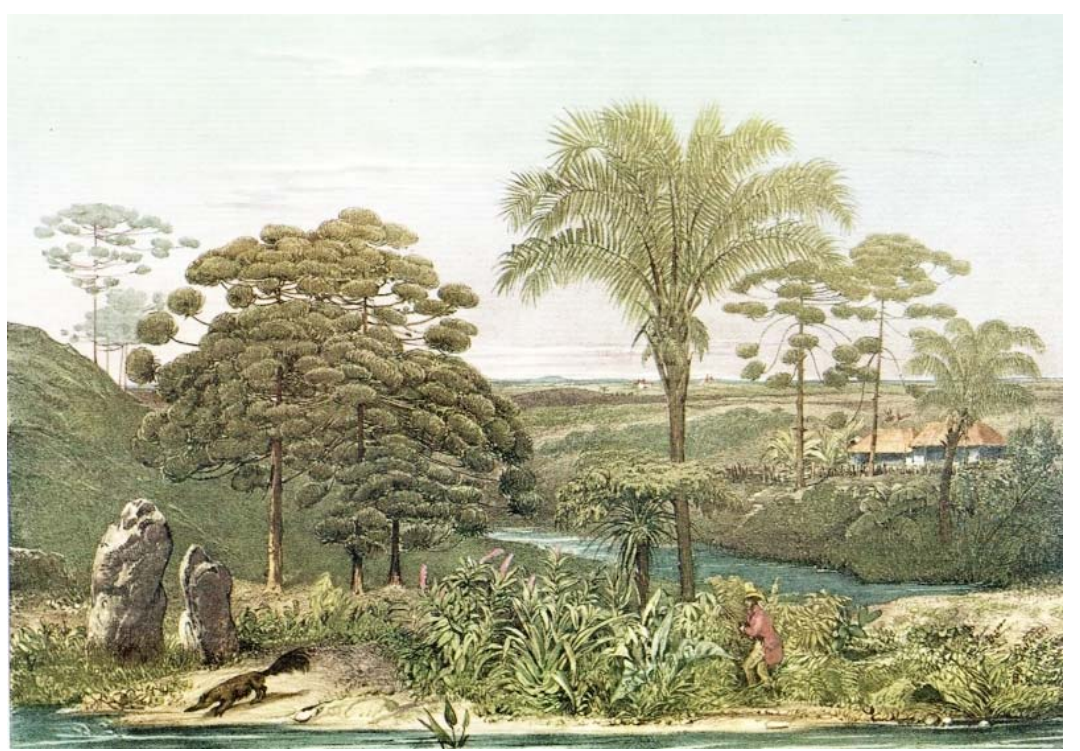

Figura 3.06: J. M. Rugendas, A caminho de Barbacena

As palavras são importantes para mobilizar os sentidos e dar força à descrição. Submeter-se a tal capricho e irregularidade seria um desastre técnico, sanitário e econômico que resultaria em uma paisagem desgraciosa, atravancada. Assim, argumentava

A impossibilidade de concentrar a população em área relativamente pequena, por exigir a configuração especial do terreno que a cidade se estenda em longos e tortuosos bracos em todas as direções; as enormes dificuldades, técnicas e financeiras, de uma terraplenagem que excederia os limites do razoável; as péssimas condiçôes estéticas em que teria de ser edificada a maior parte dos edifícios e prédios, alguns exigindo custosas fundações para assentarem no terreno firme; os onerosos transportes dos materiais; a irregularidade com que teriam de ser rasgadas as ruas e 
avenidas, sem as condições de um bom arejamento e uma conveniente ventilação da cidade; concorreriam para obstar que, nesta localidade, a população se desenvolvesse além dos estreitos limites de uma pequena e modesta cidade de verão. ${ }^{28}$

Esse quadro prospectivo para Barbacena era, pode-se inferir, uma leitura que olhava para o passado - presente e expresso em Ouro Preto. Certamente a técnica poderia subverter as determinações "caprichosas" de um sítio de topografia "irregular" que submetera outrora os colonizadores. Mas os custos seriam muito altos, principalmente em comparação com as demais opções disponíveis. Para implantar o abastecimento de água para 30 mil habitantes (número inicial, conforme exigido em lei), e.g., as despesas com Barbacena montavam a quase o dobro das que seriam necessárias para Belo Horizonte ou Várzea do Marçal. ${ }^{29}$ E, pior, o resultado seria

(...) uma aglomeração informe e sem atrativos, de milhares de casas sobrepostas, tortas, desalinhadas, sem gosto, sem conforto, serpeando colinas, trepando outeiros, descendo vales, inclinadas umas, outras achatadas sob o peso de pavimentos posteriores, e tudo isso dificultado o trânsito, obstando a regularidade do abastecimento e comprometendo a facilidade dos escoamentos. ${ }^{30}$

A crítica à Barbacena, à sua impossibilidade de ser transformada em uma cidade capital moderna, continha em si os elementos da crítica a Ouro Preto e aos outros núcleos coloniais e, consequentemente, ao próprio sítio que acabaria sendo escolhido para se erigir a nova capital. Nesse sentido, e esse é o segundo aspecto que interessa apontar, é significativo que o arraial de Curral d'El Rei seja praticamente ignorado no relatório final de Aarão Reis.

\footnotetext{
${ }^{28}$ Ibidem, p.352

${ }^{29}$ Ibidem, p.382.

30 Ibidem, p.352.
} 
Ignorado como trama e paisagem urbanas, diga-se. Afinal, o território, a paisagem natural, a topografia, a hidrografia, a climatologia seriam dissecados para estabelecer os termos de comparação. Abílio Barreto faria eco às representações do final do século XIX. O antigo arraial, dependente de Sabará, seria um aglomerado de ruas mal definidas, ladeiras arenosas com "casas baixas e deselegantes", sem proteção contra as intempéries, raras tinham vidraça e apenas duas eram assobradadas, em meio a muitas residências de pau-a-pique. Os elementos materiais seriam apagados tanto nas considerações oficiais quando, depois, por necessidade de implantação do plano, fisicamente. Não escapariam nem mesmo as igrejas, como a simplória Capela de Santana ou mesmo a Matriz de Boa Viagem. ${ }^{31}$

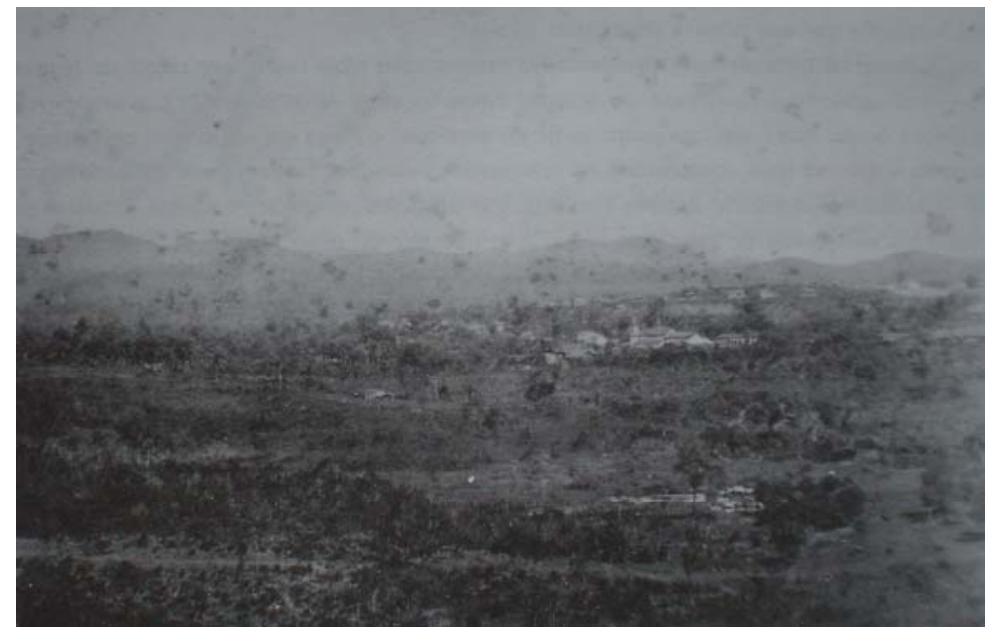

Figura 3.07: panorama do arraial de belo horizonte, vendo-se ao centro o perfil da igreja da Matriz da Boa Viagem; embaixo, a chácara que seria transformada em parque.

Fonte: A. Barreto, Belo Horizonte, 1996, v.1, p.172.

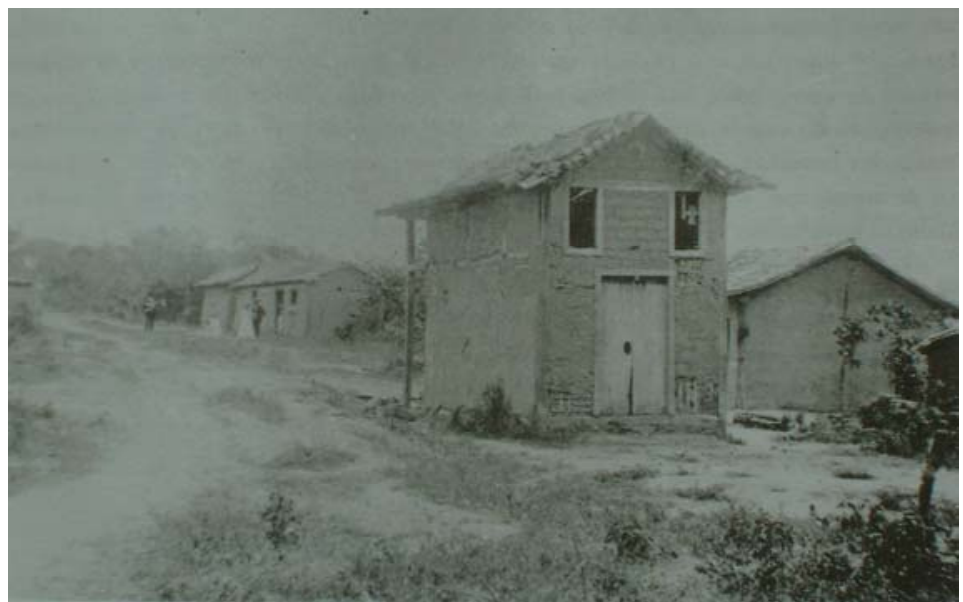

Figura 3.08: extinta capela de Santana, demolida em 1894. Fonte: A. Barreto, Belo Horizonte, 1996, v.1, p.261.

31 Abílio Barreto, Belo Horizonte: memória histórica e descritiva, vol. I, história antiga, 1996, p.222-262 passim. 


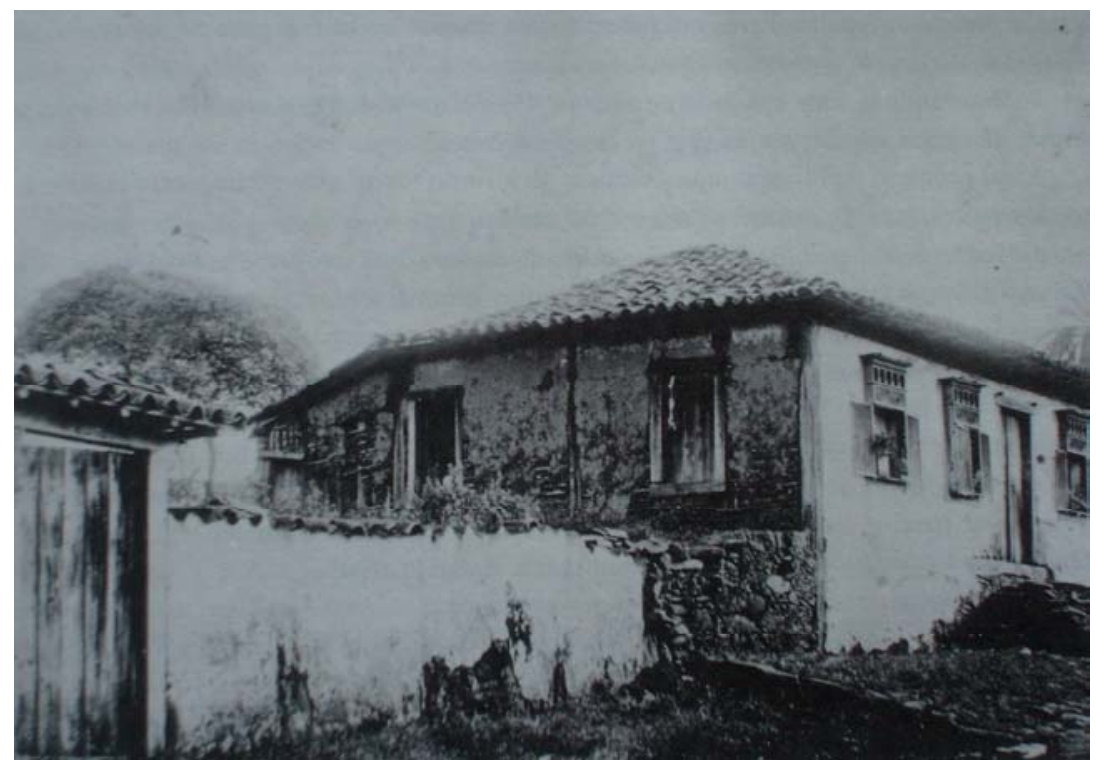

Figura 3.09: casa colonial na antiga rua do Rosário

Fonte: A. Barreto, Belo Horizonte, 1996, v.1, p.211.

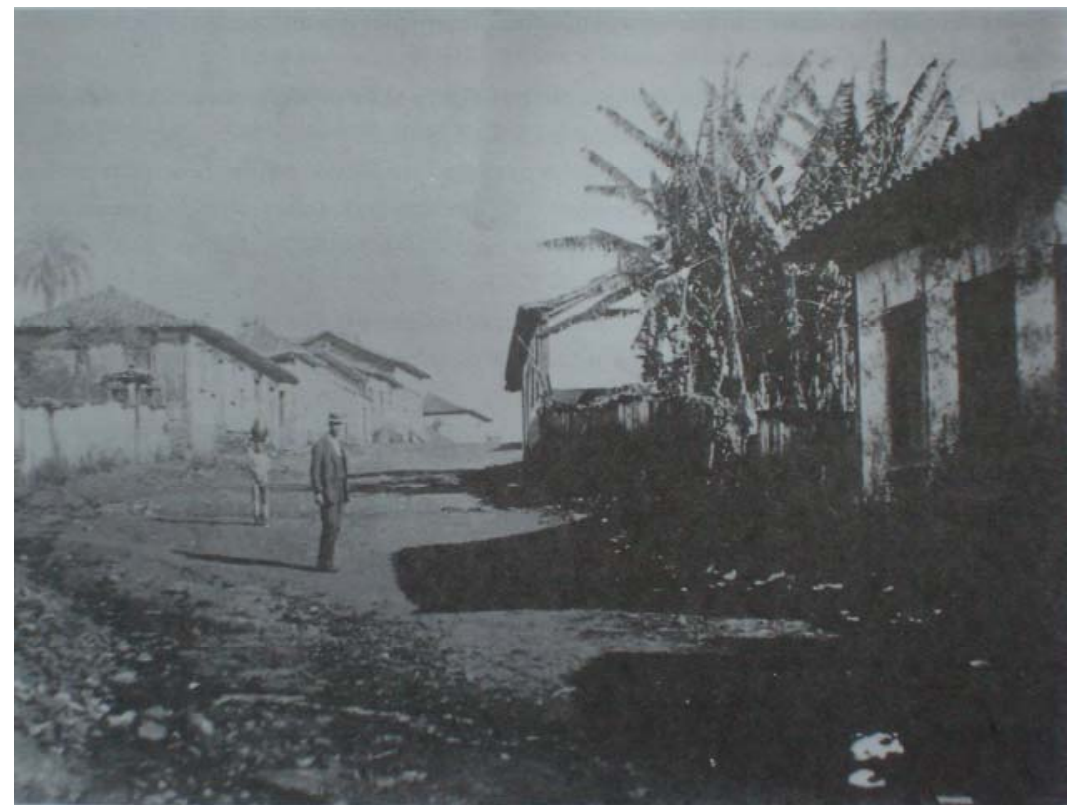

Figura 3.10: Rua do Rosário, que desembocava no Largo de mesmo nome. Fonte: A. Barreto, Belo Horizonte, 1996, v.1, p.265. 
Apagavam-se assim os suportes da memória daquela localidade. Como lembra a historiadora Heliana Salgueiro, nem mesmo o "habitante comum" estaria presente no relatório, à exceção dos trechos de topografia médica. A leitura em negativo da população local se confunde com o quadro de irregularidade do núcleo urbano original, negatividade reforçada pelas leituras de cunho determinista e evolucionista (no corte do darwinismo social) pela geração que se formou na segunda metade do século XIX e do qual os engenheiros politécnicos fizeram parte, como Aarão Reis. ${ }^{32}$ Em artigo para a Revista Geral dos Trabalhos da Comissão Construtora, em 1895, Fabio Leal perguntaria: “Quem, no futuro, cortado já o arraial de largas avenidas, de espaçosas e belas ruas, ornadas de palacetes (...), de ajardinamentos de luxo, (...) não ficará (...) surpreendido de ter habitado nele uma população tão mesquinha?". ${ }^{33}$

Por fim, o plano da nova capital iria, assim, ser feito sobre esse apagamento. O ato e o processo de fundação são contrários à "idéia de continuidade histórica". Tábula rasa, apagamento dos vestígios materiais, correções das "imperfeições naturais", como definia Leónce Reynaud acerca da tarefa de erguer capitais, em texto sansimonista que era conhecido daqueles que se formaram na Escola Politécnica do Rio de Janeiro. ${ }^{34} \mathrm{O}$ desenho rígido da malha urbana quadriculada, cortada por diagonais que seguiam a lógica da circulação dos fluxos, a delimitação de um grande parque urbano (implicando no controle da paisagem para fruição em meio a um território de paisagens pitorescas que se prestavam ao sublime) e o boulevard de contorno e delimitação da zona urbana eram a expressão de ato fundador, desejo deliberado de opor-se a um quadro urbano de núcleos de traçado irregular.

Como esclarece Heliana Salgueiro, no contrapelo da leitura de uma historiografia local sobre a criação da capital, não se pode afirmar que o plano preexistisse à escolha do sítio, apesar da "rigidez" da solução sugerir tal leitura. Nos

\footnotetext{
${ }^{32}$ Heliana A. Salgueiro, O pensamento francês na fundação de Belo Horizonte, op. cit., p.164; sobre a influência das leituras deterministas (raciais, geográficas, genéticas) na formação dos intelectuais brasileiros, cf. Lilia M. Schwarcz, O espetáculo das raças: cientistas, instituiçoés e questão racial no brasil - 18701930, 1993; Roberto Ventura também discute a formação da chamada "geração de 1870" em sua heterogeneidade e, ao mesmo tempo, aproximação e apropriação dos temas da raça, cultura, estilo e natureza nas formulações sobre o Brasil, cf. Estilo tropical: história cultural e polêmicas literárias no Brasil, 1991.

33 Apud Heliana A. Salgueiro, O pensamento francês na fundação de Belo Horizonte, op. cit., p.164.

34 Ibidem, p.159.
} 
anexos do Relatório da Comissão de Estudos das Localidades, que já apresentavam os projetos arquitetônicos, não constava tal documento. $\mathrm{O}$ desenho foi realizado após a definição política de Belo Horizonte. A triangulação para detalhamento topográfico do sítio ajudou, claramente, a definir a implantação da solução, a pensar o arranjo para tentar "garantir efeitos artísticos", a articular a arquitetura compondo "panoramas", "perspectivas recíprocas" e "pontos de vistas", como seria expresso na Revista Geral dos Trabalhos da Comissão ao longo de $1895^{35}$

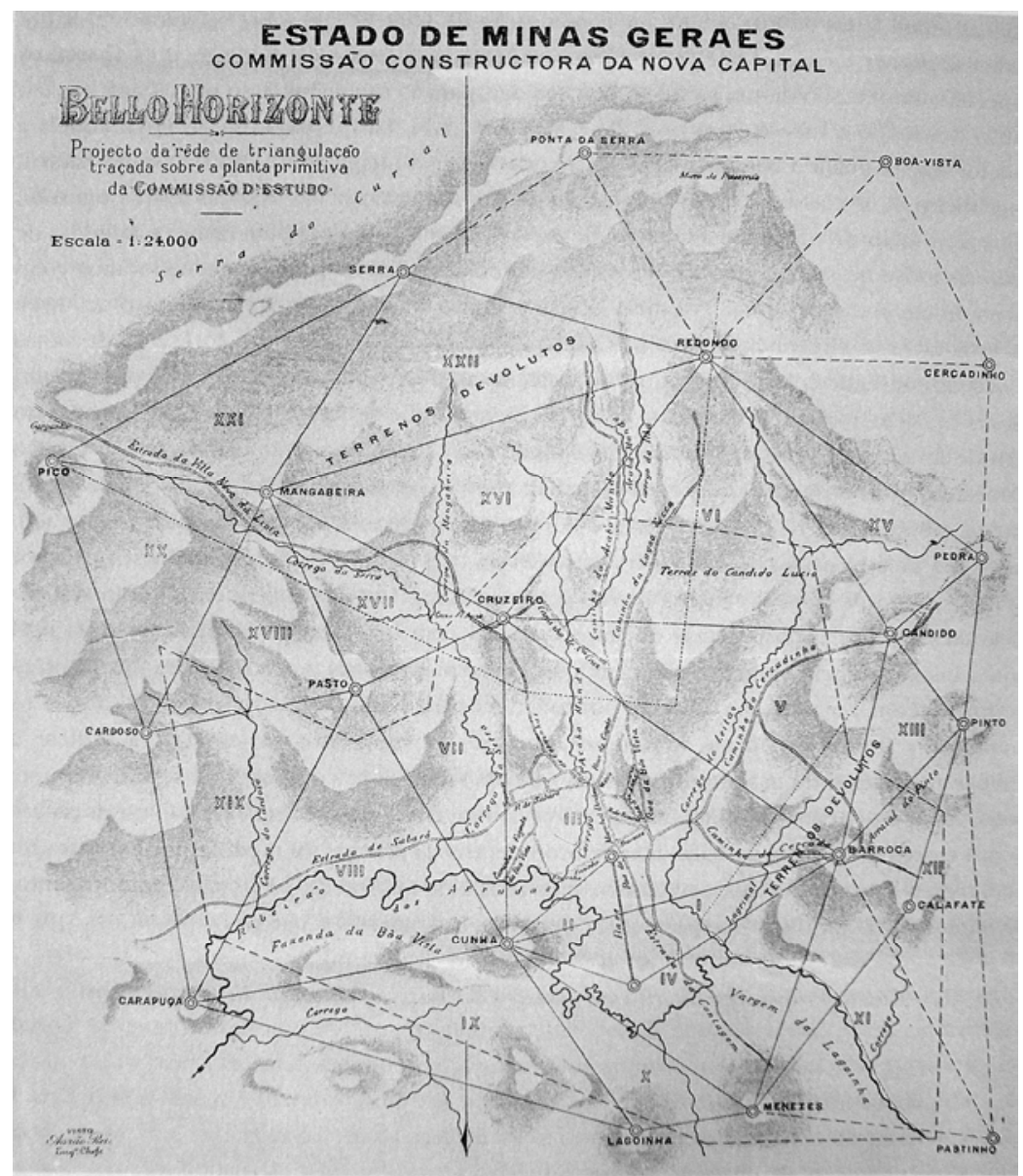

Figura 3.11: projeto da rede de triangulação traçada sobre a planta primitiva do arraial. Fonte: A. Barreto, Belo Horizonte, 1996, v.2, p.196.

35 Heliana A. Salgueiro, O pensamento francês na fundação de Belo Horizonte, op. cit., p.163-160. 


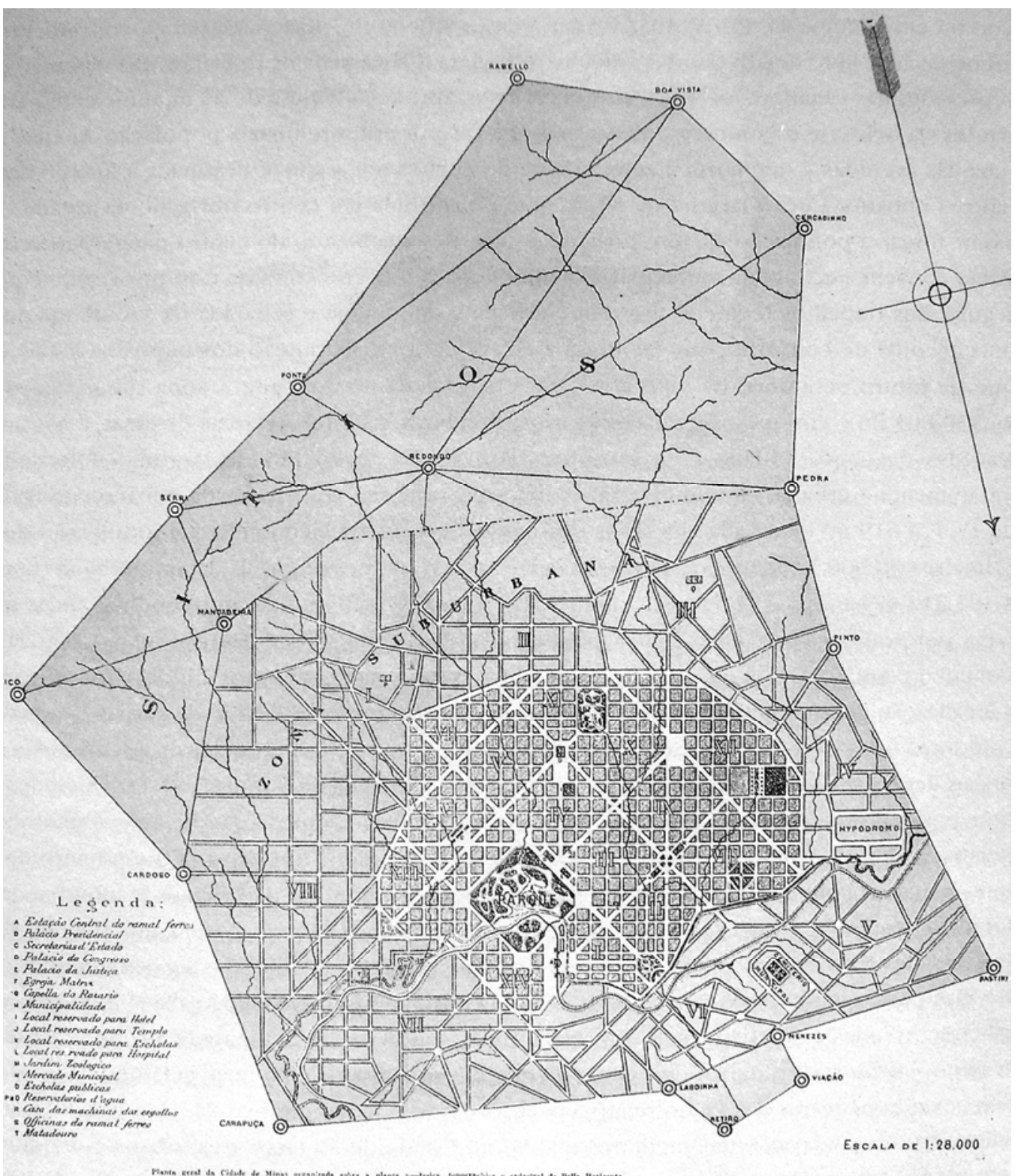

Figura 3.12: planta geral de Belo Horizonte traçada sobre as plantas geodésica, cadastral e topográfica do sítio. Fonte: A. Barreto, Belo Horizonte, 1996, v.2, p.252.

Mas a solução, de fato, submete o território, o que era outra clara diferenciação ao fazer das cidades as quais se opunha - Ouro Preto, que tentavam modernizar, Curral d'El Rei, que não mais existia, Barbacena e São João Del Rei, que foram colocadas como opção antes, enfim, a imagem da cidade colonial decadente. Solução em que se cruzavam também tradições de longa duração - como a regularidade e mesmo a noção de fechamento e auto-contenção, de clara finitude das cidades ideais do Renascimento, por meio do boulevard de contorno; assim como eram mobilizadas soluções modernas, como o parque, que remetem ao Bois de 
Boulogne e ao Bois de Vincennes de Adolphe Alphand, na Paris haussmanniana, ou mesmo ao projeto de Auguste Glaziou para o Passeio Público do Rio de Janeiro

De certo modo, em Belo Horizonte finalmente se cumpriria o desiderato de Azeredo Coutinho (embora ele se referisse às reformas necessárias para extirpar os males do Rio de Janeiro no final do século XVIII): cidade feita com previdência, método, a arte que faltara às cidade feitas no Brasil até então era, assim, princípio norteador para realizar uma nova capital.

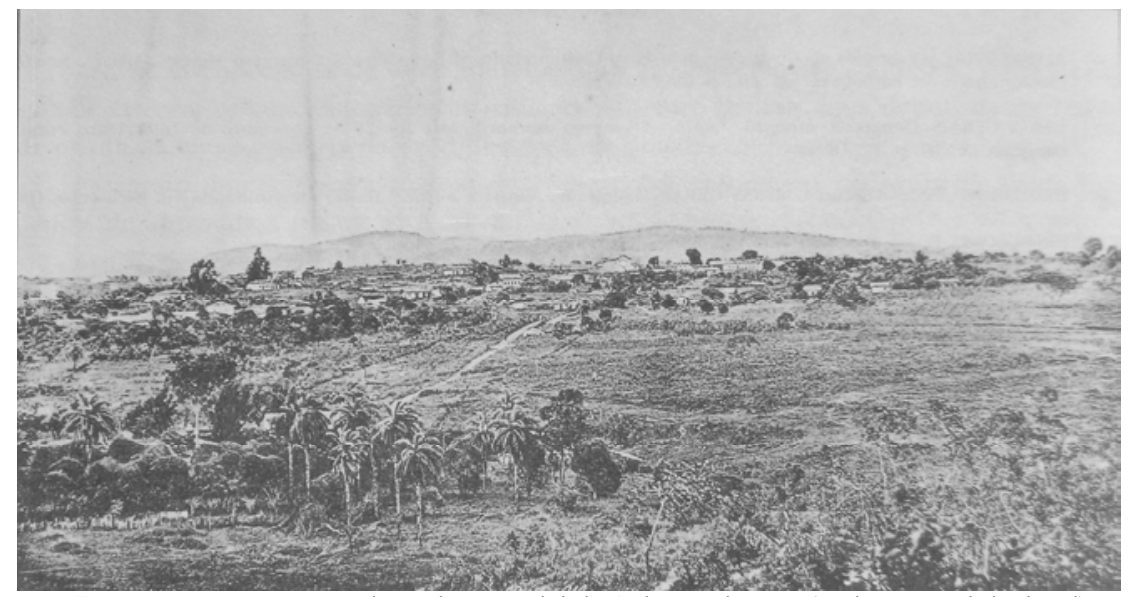

Figura 3.13: panorama do extinto arraial de Belo Horizonte (antigo Curral d'El Rei) Fonte: A. Barreto, Belo Horizonte, 1996, v.1, p.430. 
É significativo que, ao iniciar a discussão sobre o "arranjo das cidades antigas", na terceira parte (dedicada ao tema "arquitetura e urbanismo") do livro Arquitetura Contemporânea no Brasil, Yves Bruand, arquivista paleógrafo francês oriundo da Escola de Chartes, retome a oposição fundamental - interesse central desta tese - que conformou uma leitura corrente e, pode-se dizer, hegemônica acerca do tipo de cidade construído pelos portugueses na América. Significativo pelos pressupostos - interpretação, palavras, conceitos - que assume mas também pelos que deliberadamente deixa de lado.

Afinal, Bruand iria afirmar, partindo do clássico capítulo "O semeador e o ladrilhador", do livro Raizes do Brasil de Sérgio Buarque, que em "matéria de urbanismo, as cidades portuguesas da América obedeceram a critérios radicalmente opostos aos que orientaram a ordenação das cidades espanholas do mesmo continente". Reconhece que o fundamento da política de colonização é o mesmo: a possessão territorial definitiva. Contudo,

Enquanto os colonizadores hispânicos esforçavam-se para criar conjuntos urbanos disciplinados, com planos regulares em xadrez, com uma praça central agrupando [...] seus vizinhos deixavam-se guiar pela natureza dos locais, explorando a topografia e deixando que as aglomerações crescessem livremente, sem nenbum esquema imutavelmente preconcebido. ${ }^{1}$

A nota de rodapé deste excerto remete-se diretamente ao Raízes do Brasil e à polêmica que se abrira diretamente havia poucos anos. Resultado de pesquisas desenvolvidas entre 1959 e 1963, a tese de livre docência defendida pelo professor Nestor Goulart em 1964 vem relativizar e mostrar um quadro mais complexo sobre

\footnotetext{
${ }^{1}$ Yves Bruand, Arquitetura Contemporânea no Brasil, 1997, p.325, grifos nossos.
} 
o tema. De fato, iria explorar um tema que não era a ênfase do texto de Sérgio Buarque. $^{2}$

Discutindo no texto e na banca do concurso com Sérgio Buarque, lembraria que "mesmo entre arquitetos e historiadores, acreditava-se que não teria havido planos urbanísticos no Brasil colonial”. Arremataria lembrando a conhecida frase de Robert Smith: “a ordem era ignorada pelos portugueses', como 'observavam deliciados os viajantes". 3

É verdade que Bruand remete-se à polêmica; contudo logo a dá por encerrada. O plano de Salvador de meados do século XVI, que Nestor Goulart utilizara como exemplo da existência de planejamento nos dois primeiros séculos de colonização portuguesa, é-lhe insuficiente:

[Nestor Goulart] mostrou que existiu um urbanismo colonial português que não desprezava os traçados geométricos e não hesitou em retomar as criações ideais da Renascença - verdade indiscutível nas Índias e África, porém mais sujeitas a cautelas no Brasil; é verdade que o plano primitivo de Salvador [...] tinha uma regularidade relativa, mas permanecia muito flexível em sua adaptação ao relevo; além disso, ele foi logo imerso na confusão que tomou conta da cidade durante seu crescimento posterior; por outro lado, é evidente que os portugueses jamais rejeitaram o xadrez como princípio e que eles o utilizaram quando as circunstâncias eram favoráveis, mas sem lhe dar aquela rigidez absoluta, típica das criações espanholas na América. ${ }^{4}$

A escolha das colinas, dos terrenos acidentados elevados, para criação dos primeiros assentamentos e núcleos urbanos pode ter sido acertado no início - por serem mais salubres e pela facilidade de defesa, seguindo a lógica da acrópole - e ajudam a explicar a "flexibilidade do traçado" adotado no Brasil, com suas ruas serpenteando para encontrar o melhor caminho; contudo, continua Bruand, mesmo na ocupação de áreas planas o esforço de uma mínima organização racional inexistira e "a expansão ocorreu de maneira espontânea na medida das necessidades". 5

\footnotetext{
${ }^{2}$ Há que se considerar que boa parte da polêmica, que existiu de fato se construiu a posteriori pelas leituras e extrapolações (como a de Bruand) que já existiam e que ganharam força interpretativa e operativa a partir de Raizzes do Brasil.

${ }^{3}$ Nestor G. Reis, Contribuição ao estudo da evolução urbana no Brasil (1500/1720), 2000 [1968], p.13.

${ }^{4}$ Bruand, op.cit., p.325, nota 03.

5 Ibidem.
} 
Assim, o autor francês arremata em uma (a princípio e aparentemente) aporia: por um lado, o "urbanismo português foi mais negativo do que positivo em relação à tarefa de planificação propriamente dita", conquanto reconheça que amiúde a ação empírica tenha aproveitado bem as "condições locais"; por outro lado, e talvez no decurso desse aproveitamento empírico - que na verdade decorre de uma tradição secular do saber fazer anônimo do construtor lusitano, se seguirmos a elaboração de Lucio Costa que embasa Bruand ${ }^{6}$-, o urbanismo português "foi altamente positivo no setor arquitetônico, onde revelou ser admirável a unidade dos edifícios construídos". É a "unidade de estilo" daí decorrente, e não a falta de rigidez da malha urbana, que emprestaria aos centros antigos o "encanto delicado e um pouco anacrônico" que teriam. ${ }^{7}$

Tour de force que estabelece uma conclusão peremptória - mesmo com os cuidados e ressalvas que pontuam a escrita - logo na primeira página dessa terceira parte do livro de Bruand. Contudo, tal conclusão nasce da própria estrutura argumentativa da Arquitetura contemporânea no Brasil, cujo ponto de partida, como explicitado na "introdução", é uma leitura não determinista (ou que se esforça para não sê-lo) sobre o meio - histórico, geográfico, econômico, social e cultural brasileiro. Portanto, uma leitura que constantemente remete-se à herança do passado, à "herança colonial [que] não deixou de pesar intensamente sobre o presente", ${ }^{8}$ para compreender as transformações arquitetônicas do século XX.

Essa operação analítica não se deve apenas ao historiador interessado nos fios narrativos da longa duração para compreender substratos culturais, suas permanências e rupturas. $\mathrm{O}$ voltar-se para e a avaliação da herança e dos significados desse passado é, de fato, um passo constitutivo do esforço por pensar e formular uma arquitetura "brasileira", desde os próceres do movimento neocolonial" até os articuladores da viravolta modernista, Lucio Costa à frente. Passo constitutivo,

\footnotetext{
6 Em depoimento por ocasião do seminário internacional "Um século de Lúcio Costa" (Rio de Janeiro, 2002), Yves Bruand reafirmaria que um dos grandes problemas enfrentados por Lucio Costa foi o aproveitamento das lições da arquitetura civil luso-brasileira do período colonial pela arquitetura contemporânea (modernista), cf. Y. Bruand, Lucio Costa: o homem e a obra, In Um modo de ser moderno, 2004, p.15; a elaboração sobre a "boa tradição" já estava claramente delineada por Costa em, e.g., Documentação necessária, Revista do Serviço do Patrimônio Histórico e Artístico Nacional, 1937, p.31-39.

${ }^{7}$ Idem, Arquitetura Contemporânea no Brasil, 1997.

8 Ibidem, p.19.

9 Joana Silva, Nacionalismo e Arquitetura em Ricardo Severo: Porto 1869 - São Paulo 1940, 2005.
} 
também e por conseqüência, da tessitura da "trama" da historiografia da arquitetura brasileira. ${ }^{10}$

Em meio a uma questão - os vínculos discursivos e operacionais com o passado, colonial sobremaneira - que tem sido cada vez mais problematizada na historiografia recente da arquitetura, interessa a este capítulo abordar um tópico específico: identificar e discutir a maneira como o tema da cidade colonial no Brasil foi apropriado, lido e articulado nos textos constituintes da historiografia da arquitetura sobre o país. Quais são as matrizes teóricas, quais as referências mobilizadas, quais as palavras e quais os autores (citados direta e/ou indiretamente) utilizados para construir essa(s) narrativa(s)?

Assume-se como ponto de partida o livro de Yves Bruand porque, primeiro, é um documento que consolida a trama hegemônica dessa historiografia; ${ }^{11} \mathrm{em}$ segundo lugar, porque ainda é, pode-se dizer, o trabalho analítico de maior fôlego e o panorama mais abrangente da arquitetura brasileira, cuja influência se faz sentir na formação acadêmica dos arquitetos e, mais especificamente, dos que trabalham com história da arquitetura e da arte; por fim, porque permite mapear os aparatos teóricos e conceituais que suportam a construção da narrativa.

Deve-se enfatizar que a abordagem da historiografia da arquitetura, embora não prevista no projeto original desta tese, pode revelar, formula-se como hipótese, algumas "pontes" da "genealogia" das representações sobre a cidade colonial no Brasil. Afinal, o tema da cidade colonial não é objeto de estudo da maioria desses textos conquanto uma das referências fundamentais, como em Bruand, para entender os elementos (trans)formadores do século XX. São, portanto, e guardando as proporções, narrativas de formação e explicação do Brasil. Para tais textos era necessário, e legítimo como procedimento de análise, apoiar-se em interpretações já construídas, absorvidas, consolidadas. Entretanto, quais são essas chaves de leitura? A apropriação é minimamente crítica? Superam ou enredam-se no problema da "circularidade da interpretação", i.e., de tomar-se uma representação como fato histórico que, assim, se perpetua (ou de ler nos documentos textuais e iconográficos de determinado contexto o que já é sabido a priori)? Assumidas acriticamente, não se

\footnotetext{
${ }^{10}$ Carlos Martins, "Hay algo de irracional...", Block, 1999.

${ }^{11}$ Idem, Arquitetura moderna no Brasil: uma trama recorrente, In Arquitetura e Estado no Brasil, 1989.
} 
rompem (ou nem ao menos se problematizam) as interpretações construídas historicamente. $^{12}$

Propõe-se então, na leitura que se segue, mapear especificamente as referências à cidade colonial brasileira que fundamentaram essas várias narrativas. $\mathrm{O}$ ponto de partida é o livro de Yves Bruand, ponto de chegada e consolidação da trama historiográfica hegemônica sobre a arquitetura brasileira - e ainda hoje o documento mais completo e exaustivo na discussão do tema com tal abrangência. ${ }^{13}$

\subsection{Antiurbanismo ou as limitações impostas pelo passado}

O livro de Bruand abre-se com uma abordagem, a princípio, de história tradicional. Busca compreender as condicionantes do meio brasileiro para que seu "olhar estrangeiro" possa abarcar melhor o objeto de estudo a que se propõe enfrentar. É uma narrativa que lembra, em alguns momentos, as estruturas dos relatos dos viajantes do Oitocentos ou ainda as das explicações do pensamento social brasileiro para a condição nacional, tributárias de leituras evolucionistas. Entretanto, e obviamente, Bruand vai além: percebe-se a atenção metodológica com o estudo da longa duração e, mais importante, com a relevância do papel do sujeito histórico ante os riscos de uma leitura determinista das estruturas temporais. Se escapa de certas explicações fáceis ou relações primárias de análise, recai com freqüência nas armadilhas deterministas da leitura da "mentalidade e da psicologia do povo brasileiro", que empreende, escudado em Fernando de Azevedo, ainda na introdução.

Um dos principais substratos para construção da sua argumentação, não se deve olvidar que o livro do importante educador Azevedo insere-se no contexto das grandes interpretações do Brasil dos anos 1930 e 1940; mais ainda, que esteve envolvido nos debates sobre a formação de uma arte nacional nos anos 1920, tendo organizado, insuflado por Ricardo Severo e José Mariano, uma série de reportagens sobre a arquitetura colonial, publicadas em O Estado de São Paulo em $1926 .{ }^{14}$ Cabe

\footnotetext{
12 Cf. Carlo Ginzburg, Mitos, Emblemas e Sinais, 1989, p.63-64, 79 et seq.

${ }^{13}$ Carlos Martins, Arquitetura e Estado no Brasil, 1989; Nelci Tinem, O alvo do olhar estrangeiro, 2006, p. 3341.

${ }^{14}$ Cf. H. Segawa, Arquiteturas no Brasil, 1999, p.37.
} 
observar que o livro A Cultura Brasileira, utilizado profusamente por Bruand na sua parte introdutória, apresenta também uma leitura das formações urbanas para compreensão do seu complexo tema.

Que leitura é essa? Apoiando-se principalmente em Gilberto Freyre, Azevedo enfatizaria o contraste entre a miséria das cidades e o dinamismo e esplendor do mundo rural no período colonial. Ilustrando essa parte do livro com fotografias de panoramas urbanos de várias cidades brasileiras, afirmaria que mesmo as maiores cidades do século XVI e do início do século XVII não passavam de "lugarejos mal construídos e abandonados a si mesmos, que cresciam sem nenhum plano preconcebido". Arremataria com a assertiva que o "urbanismo" seria uma condição muito recente. ${ }^{15}$

Bruand segue a argumentação: compreender o passado - as cidades aí incluídas - é fundamental para estabelecer os elementos dessa mentalidade, suas características e "traços essenciais". A ocupação original de muitas cidades brasileiras em sítios elevados (conforme discute no início do trecho sobre as condições geográficas), em terrenos acidentados, restringiu a malha urbana inicial a platôs muito estreitos. Isso acarretaria na dificuldade de estabelecer e organizar uma "malha viária lógica e eficaz" e, como corolário, na consecução de ruas estreitas. Entretanto, esse tipo de estrutura foi importante e eficiente para minorar os efeitos do clima tropical: a luminosidade excessiva e o calor intenso. ${ }^{16}$

De maneira esquemática - em relação à escolha de sítios desfavoráveis -, essa assertiva servia para falar do Rio de Janeiro, de São Paulo, de Salvador e mesmo do Recife. A situação dessas cidades ilustrava o peso da "herança colonial" sobre o presente. Era um "peso" que se traduzia na dimensão física e interferia na arquitetura - circunscrita durante muito tempo ao padrão que o lote colonial impunha; e, talvez principalmente, que se traduzia na "atitude" em relação à cidade e ao seu planejamento. Baseando fundamentalmente na leitura de Sérgio Buarque do

\footnotetext{
${ }^{15}$ F. Azevedo, A Cultura Brasileira, 1964 [1946], p.131-132.

16 Bruand, op.cit., p.12; ademais, deve-se apontar que, para Bruand, o clima tropical conformou uma influência decisiva para a arquitetura no Brasil, na busca sucessiva de soluções para reduzir seus efeitos, o que teria possibilitado, e.g., a incorporação decisiva do brise-soleil como elemento plástico da linguagem modernista. Adiante-se que essa leitura já estava presente em Goodwin.
} 
"desleixo" português e nos estudos de Aroldo de Azevedo sobre as "Vilas e cidades do Brasil colonial", Bruand afirmaria que:

Com efeito, os problemas urbanísticos sempre foram negligenciados no Brasil, atitude que perdurou até recentemente. Pode-se perceber nisso a herança colonial dos portugueses, que, ao contrário dos espanhóis, jamais pensaram em dar às cidades que criaram na América um caráter ordenado a ponto de um geógrafo [Aroldo de Azevedo] que estudou o assunto empregar a expressão "antiurbanismo". ${ }^{17}$

Negligência, falta de caráter ordenado, transformação lenta, falta de sensibilidade à natureza, aqui e ali os termos ressoam, direta ou indiretamente, as "Raízes do Brasil", de Sérgio Buarque. Por vezes o texto de Bruand aponta uma relação complexa, de dados positivos e negativos, dessa herança para a cidade, para a paisagem urbana em especial, como dito alhures. Outras, a negatividade dessa atitude desinteressada em relação à planificação vincula-se à leitura da própria cidade como um todo, que se torna assim a materialização das "limitações impostas pelo passado". 18

Parece irromper aqui claramente o problema da "circularidade da interpretação" a que se aludiu antes. Lê-se nos exemplos apenas o que se sabe de antemão. Os documentos não são interpelados e assim se reitera a interpretação original que, no caso, é uma representação construída historicamente acerca da cidade colonial no Brasil. Contudo, há também deslizamentos na leitura e nos usos de palavras e expressões.

Tome-se, e.g., o uso do termo "antiurbanismo". Em Bruand, em trecho citado acima, o termo é usado claramente para se referir a uma atitude de negligência em relação aos problemas urbanísticos no Brasil - atitude que perduraria, avaliava então, de maneira geral, até o momento de suas pesquisas. Fernando Azevedo, por sua vez, em "A cultura brasileira", afirmaria que o "urbanismo" seria condição muito recente. Não usa a palavra "antiurbanismo", mas por oposição sabe-se em que registro se move. Urbanismo refere-se não apenas à disciplina moderna que se estrutura entre meados do século XIX e início do XX, quando surge a própria

\footnotetext{
${ }^{17}$ Bruand, op.cit., p.20; grifos nossos.

18 Ibidem.
} 
palavra; urbanismo é utilizada por Azevedo para designar toda atividade ou política urbanizadora. Daí porque o uso do termo mesmo para o período colonial, quando não existia tal palavra. ${ }^{19}$

Oliveira Vianna, por sua vez, ao falar sobre o "centrifugismo" e o "complexo antiurbano" do que denomina homo colonialis implica claramente referir-se a uma atitude negativa em relação aos núcleos urbanos, às cidades. $\mathrm{O}$ povoamento disperso teria levado a moldar uma psicologia "amante da solidão e do deserto", que evita a cidade e tem gosto pela floresta e pelo campo e cujo exemplo mais acabado seria o "paulista do bandeirismo"; ${ }^{20}$ i.e., o antiurbanismo não poderia ser visto, a princípio, como uma oposição à política urbanizadora ou ao saber da antiga arte urbana, de arruar, de riscar os núcleos urbanos. O registro aí é outro e pode ser revelador dessas mudanças de significações que passam a ter força narrativa e a sintetizar chaves de leitura, como parece ter ocorrido com a palavra "antiurbanismo".

Aroldo Azevedo, em "Vilas e cidades do Brasil colonial", proporia matizar essa visão do tão propalado antiurbanismo colonial. Seguindo a argumentação de Oliveira Viana e de outros autores (como Alcântara Machado, Paulo Prado e Sérgio Buarque) que corroborariam a tese da "verdadeira aversão à vida urbana" - que, a propósito, teria persistido ainda sob o Império, a confiar nos relatos de viajantes como Saint-Hilaire e Martius -, ainda assim Azevedo não aceitaria (totalmente) esse moto explicativo. Ao contrário, propunha entender o que significam as vilas e cidades no período colonial, cuja designação pouco dizia das possíveis diferenciações e hierarquizações (demográficas, sociais e ou econômicas) entre si. Ao assumir sob uma mesma rubrica, de "aglomerados urbanos", as 12 cidades e 213 vilas do período colonial constituiriam um número significativo para um território em formação com algo em torno de 5 milhões de habitantes. ${ }^{21}$

Observe-se que Aroldo Azevedo está dialogando, de fato, muito mais próximo ao registro de Oliveira Vianna, ainda que o matizando, do que do uso que Bruand faria do termo, a dizer, Azevedo mobiliza a palavra urbanismo com um

19 Para aprofundar essa leitura de Azevedo, cf. A Cultura Brasileira, 1964 [1946], especialmente Parte I, cap. III, “as formações urbanas”, p.127-160.

${ }^{20}$ Cf. O. Vianna, Instituições políticas brasileiras, 1999 [ed. orig. 1949], vol. I, $2^{\text {a }}$ parte, p.135-136; veja-se todo o cap. IV, cujo título é por si revelador, "o significado sociológico do antiurbanismo colonial (gênese do espírito insolidarista)".

${ }^{21}$ Cf. A. Azevedo, Vilas e cidades do Brasil colonial, 1956, p.84-88. 
sentido muito próximo do sentido de urbanidade, como se usava amiúde até princípios do século XIX.22

A "metodologia dos contrários", como ressaltou Antonio Candido, utilizada na construção da análise de "Raízes do Brasil" tem um dos pares antinômicos na comparação cidade portuguesa - cidade espanhola. Contudo, deve-se dizer que esse não era o objetivo central de Sérgio Buarque. A interpretação do Brasil daí decorrente, na qual a avaliação da herança do passado, da tradição ibérica, é central para entender uma série de permanências - patrimonialismo, cordialidade, personalismo, etc. -, secunda as formulações para pensar caminhos em direção a um Brasil Republicano de fato. ${ }^{23}$

É importante ressaltar que essa representação em negativo da cidade colonial é anterior ao livro seminal de Sérgio Buarque. A contestação a algumas das conclusões do capítulo "O semeador e o ladrilhador" - principalmente em relação à falta de planejamento urbano por parte dos portugueses na América - inclusive não desmerece suas teses centrais. O próprio autor, em entrevista em 1981, apontava, ainda que de forma imprecisa, para a necessidade de reformulação de vários trechos do livro, incluindo o capítulo em questão: “o mesmo [ser muito estático] vale para aqueles trechos sobre o ladrilhador, o semeador: acho aquilo ensaístico demais, precisaria refazer". ${ }^{24}$

Contudo, sabe-se que essa leitura de Raízes que opõe os tipos de colonização espanhola e portuguesa - materializados em suas cidades - tornar-se-ia uma interpretação corrente e, mais ainda, hegemônica. Pode-se dizer que o texto de Sérgio Buarque, sobretudo a partir da segunda edição, de 1948, serviu, direta ou indiretamente, a esse tipo de leitura. ${ }^{25}$ Certo é que Bruand se escuda nela e descarta

\footnotetext{
22 O dicionário de Raphael Bluteau registra que urbanidade "vem a ser o mesmo que comedimento e bom modo dos que vivem na cidade, em diferença da rusticidade e grosseria dos que vivem nas aldeias e no campo", cf. verbete urbanidade, Vocabulario Portuguez. \& Latino, áulico, anatômico, architectonico..., 1712-1728, p.587 [edição on-line do Instituto de Estudos Brasileiros - USP, disponível em: http://www.ieb.usp.br/online/index.asp].

${ }^{23}$ Não à toa o último capítulo é dedicado à "Nossa Revolução", Cf. Holanda, S. B. Raíres do Brasil, 1995.

${ }^{24}$ Holanda, S. B. A revolução subterrânea [em entrevista]. Folha de São Paulo, 08 ago. 2004, p.13 (a entrevista é de 1981).

25 Por ocasião da segunda edição, cujo texto sofreu modificações consideráveis, como apontou o próprio Sérgio Buarque no prefácio, o capítulo "O passado agrário", original de 1936, foi desdobrado em dois, "Herança rural" e "O semeador e o ladrilhador".
} 
sumariamente as divergências e os novos dados apresentados pelas pesquisas de Nestor Goulart - em um período em que o autor de Arquitetura Contemporânea no Brasil está desenvolvendo suas atividades no país. ${ }^{26}$ Sintomaticamente, Bruand não descarta as leituras do mesmo Nestor Goulart no que diz respeito à análise arquitetônica propriamente dita (os artigos publicados na revista Acrópole na década de 1960 que seriam a base para a publicação do "Quadro da Arquitetura no Brasil" na década seguinte).

Aponta-se aqui para uma hipótese: aceitar a polêmica e problematizar tal representação sobre a cidade colonial desmontaria alguns pressupostos-chave da sua narrativa, em que as soluções modernistas aparecem como conseqüência inescapável no enfrentamento dessa herança adversa. $O$ uso dos pilotis, e.g., "uma das características mais marcantes da nova arquitetura brasileira", permitiria escapar às injunções do relevo acidentado. ${ }^{27}$ Permitia libertar-se de um dos "determinantes", para usarmos um expressão da proposta metodológica de Carlos Lemos, ${ }^{28} \mathrm{da}$ arquitetura e da paisagem urbana tradicionais portanto.

Bruand reafirmará também que a relação tradição-modernidade é constitutiva da "nova arquitetura"; daí a preocupação com a preservação do passado e dos seus monumentos, a participação decisiva de Lucio Costa no SPHAN, a busca pela compreensão dos princípios da tradição luso-brasileira dos primeiros séculos para conciliar com os princípios da arquitetura "moderna", etc. ${ }^{29}$ Mas, que passado é este que se busca preservar?

Dois episódios narrados no livro ajudam a ilustrar essa questão. Ao discutir o “estilo neocolonial", afirma que esse tipo de movimento tradicionalista não poderia grassar em São Paulo porque esta sempre foi uma "cidade inteiramente voltada para o presente e para o futuro, que desprezava e audaciosamente destruía os vestígios do

\footnotetext{
${ }^{26}$ Bruand residiu e pesquisou no Brasil entre 1960 e 1969; Nestor Goulart defendeu sua tese de livredocência em 1964 e publicou a primeira edição de Evolução urbana no Brasil em 1968.

${ }^{27}$ Bruand, op.cit., p.12.

${ }^{28}$ Lemos partiria da premissa de que o partido arquitetônico é uma "conseqüência formal derivada de uma série de condicionantes ou de determinantes", que seriam: as técnicas construtivas, as condições topográficas e físicas do sítio, o programa de necessidades, as possibilidades financeiras do empreendedor, a legislação reguladora e as normas sociais e ou regras funcionais, cf. C. Lemos, Arquitetura brasileira, 1979, p.07-10.

${ }^{29}$ Cf. Y. Bruand, Arquitetura contemporânea brasileira, 1980, p.25, 71, 123.
} 
seu passado, aliás pouco significativos quando comparado aos de outras regiões". ${ }^{30}$ Ademais, São Paulo nunca passara, no período colonial, de uma "grande aldeia bastante pobre". ${ }^{31}$

É uma clara ressonância de formulações como as de Mário de Andrade. Ao discutir o problema da demolição da Sé de Salvador, nos anos 1920, conforme registra no seu diário d'O Turista Aprendir, Mário compara Natal, onde estava hospedado, a São Paulo:

Natal é feito S. Paulo: cidade mocinha, podendo progredir à vontade sem ter coisa que dói destruir. Isso é muito importante para nós. O problema da destruição ou conservação da Sé, da Bahia, por exemplo, confesso que por mim não sei resolver.

$[\ldots]$

O problema da Sé está mais é anunciado errado. É muito mais grandioso do que a derrubada ou não derrubada dum casarão pra alargamento de rua. O próprio centro urbano da cidade alta é que se tem de resolver se é prático ou não ficar onde está. Todas aquelas ladeiras, quedas de sopetão, torceduras de terrenos são absolutamente contrárias a qualquer norma utilitária de urbanismo contemporâneo. Não é possível aplainar aquilo e retificar as ruas sem arrasar tudo. Ou se destrói tudo para atualizar aquilo, ou, qualquer paliativo destruirá tradições curiosas e mesmo valiosas que nem a dita Sé, não passando de paliativo e não resolvendo nada - esse é o problema. ${ }^{32}$

Não haveria valores permanentes nem em Natal ou em São Paulo. Contudo, isso é lido negativamente por Bruand. Uma civilização que se pretende grande precisa tê-los, afirma. Mas a lamentação não é porque quase tudo se destruiu - afinal os vestígios do passado em São Paulo seriam "pouco significativos" - mas pela atitude que continua a destruir tudo:

(...) em parte alguma a fúria destrutiva foi exercida com maior constância e o foi tão bem que essa cidade de mais de quatrocentos anos não conserva quase nada dos séculos passados,

\footnotetext{
${ }^{30}$ Ibidem, p.52; ademais, essa foi uma representação corrente na historiografia sobre a cidade de São Paulo, como discute Amilcar Torrão Filho, Paradigma do caos on cidade da conversão?: a cidade colonial na América portuguesa e o caso de São Paulo na administração do Morgado de Mateus (1765-1775), 2004.

31 Y. Bruand, Arquitetura contemporânea brasileira, 1980, p.54.

32 Andrade, M. O Turista Aprendir, 1976, p.254-55, "Natal, 29 de dezembro [de 1928], 17 horas"; grifos nossos.
} 
e as testemunhas do começo do século atual desapareceram, por sua vez, há uma década. ${ }^{33}$

Atitude cujas conseqüências mais expressivas - negativamente - deram-se no Rio de Janeiro, como discute acerca dos episódios da derrubada do Morro do Castelo, nos anos 1920, e das reformas estadonovistas, na gestão do prefeito Dodsworth. $^{34}$

De qualquer maneira, percebe-se que os problemas de crescimento urbano colocados em pauta no século XX principalmente nas cidades grandes eram agravados, na leitura de Bruand, pelo contexto topográfico e pelas seqüelas da tradição colonial.

O outro episódio - que ajuda a entender a valoração da relação entre tradição e modernidade - é a leitura que Bruand empreende do "arranjo antigo" de Salvador e, principalmente do plano de urbanismo desenvolvido pelo EPUCS, dirigido por Mário Leal Ferreira e Diógenes Rebouças. Toma-o como um exemplo para pensar a tarefa do planejamento no Brasil e para lidar com a questão da preservação - no caso, do "mais belo conjunto urbano dos séculos XVII e XVIII que foi legado pelos portugueses ao continente americano", 35

De fato, os princípios do plano põem o tema da preservação como questão central. E isto, ressalta, é feito sem sentimentalismo, "isento das nostalgias românticas dos amadores de casebres e ruínas para quem a miséria não passa de um tema para a poesia". Tanto que uma das primeiras tarefas foi a identificação dos "verdadeiros valores históricos" para distingui-los dos que eram objeto apenas de interesse pitoresco, podendo destrui-los desde que necessário e justificado racionalmente. A organização da circulação também ajudava a manter o "caráter da capital colonial, assegurando-lhe meios de integrar-se sem choques na vida moderna", porque partira de uma "interpretação inteligente da tradição cultural portuguesa no Brasil". 36

\footnotetext{
33 Bruand, op.cit., p.333.

34 Ibidem, p.334-337.

35 Ibidem, p.340.

36 Ibidem, p.342.
} 


\section{2 delineamentos narrativos}

Se o livro de Bruand configura um momento de consolidação desta trama hegemônica da historiografia da arquitetura brasileira, é importante identificar se representações tão estruturadas sobre a cidade são explicitadas no momento inicial de delineamento da trama: os livros de Philip Goodwin, Brazil Builds (1943), e de Henrique Mindlin, Modern Architecture in Brazil (1956).

Em Goodwin, não há referência explícita ao tema da cidade, embora o vínculo entre passado e presente seja crucial para explicar a pujança e a originalidade da arquitetura brasileira. A cidade aparece entrevista em meio a narrativa fotográfica - de Kidder Smith - que estrutura o livro. O vínculo é também, e fortemente, imagético; e, ademais, apóia-se no esquema teórico que vinha sendo desenvolvido por Lucio Costa desde Razões da nova arquitetura. ${ }^{37}$

37 Martins, C. A. F. "Hay algo de irracional...': apuntes sobre la historiografía de la arquitectura brasileña. Block, 1999, p.11. 


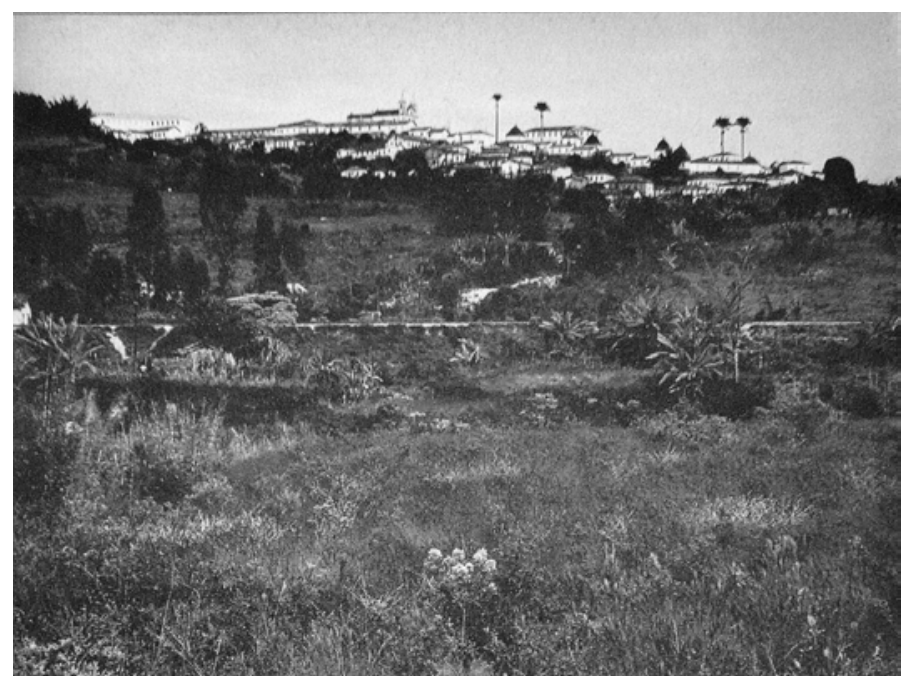

Figura 4.01: Congonhas do Campo (na narrativa fotográfica de Kidder Smith)

Fonte: P. Goodwin, Brazil Builds, 1943, p.45.

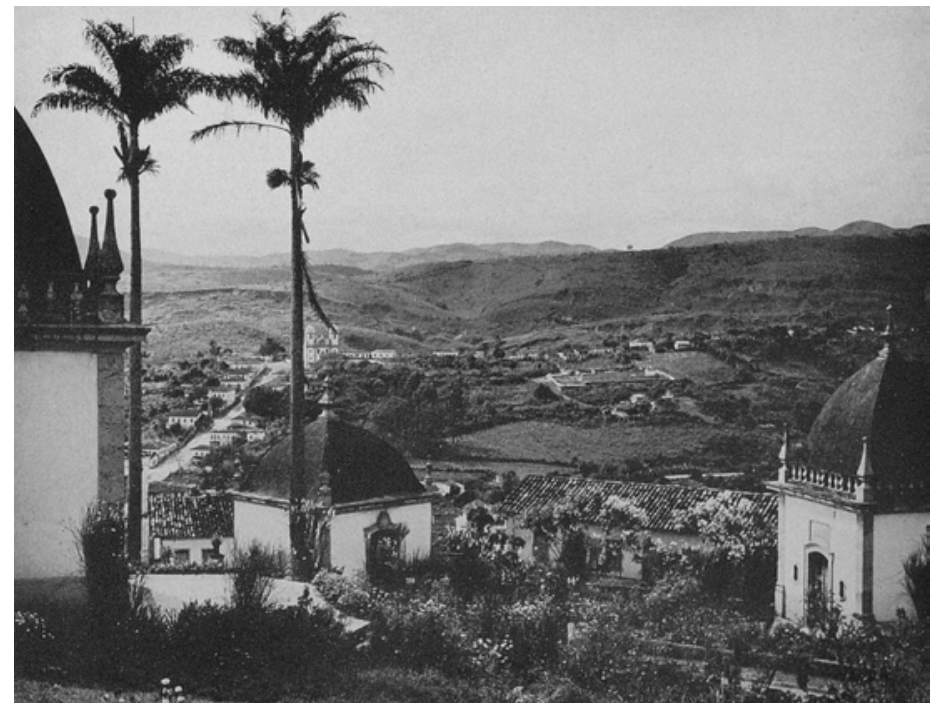

Figura 4.02: Igreja de Bom Jesus de Matosinhos em Congonhas do Campo Fonte: P. Goodwin, Brazil Builds, 1943, p.45.

Se a nova arquitetura filia-se às mais puras tradições mediterrâneas, que seria a tradição clássica herdada dos gregos e romanos, dever-se-ia procurar as leis fundamentais que subjazem às variações formais ao longo da história. Lições que estariam presentes na arquitetura civil luso-brasileira do construtor anônimo do período colonial. Os estudos historiográficos, a atividade de crítica e a obra, mesmo das poucas e significativas casas, de Lucio Costa apontam para a construção historiográfica desse vínculo. Lembremo-nos já da advertência da época da reforma da Escola Nacional de Belas-Artes, em 1930: os alunos deveriam conhecer "perfeitamente" a arquitetura brasileira do período colonial, não para "transposição 
ridícula de seus motivos" mas, sim, pelas lições de "simplicidade, perfeita adaptação ao meio e à função, e conseqüente beleza" ${ }^{38}$ Contudo, essa lição seria encontrada também na conformação da estrutura urbana do período colonial?

Mesmo assim, pelo menos dois aspectos chamam a atenção em Brą̣il Builds. Primeiro, o entusiasmo na descrição da inovação dos elementos de proteção ao calor e aos reflexos luminosos - a grande contribuição, em sua leitura, à originalidade não questiona ou ao menos observa algumas situações que são no mínimo conflitantes, a exemplo da solução da Torre d’Água de Olinda, de autoria de Luís Nunes e de Fernando Saturnino de Brito. Os elementos vazados são exemplares. A relação com o sítio de implantação não é sequer apontada. ${ }^{39}$ Como se dá então esse vínculo entre passado e presente, entre tradição e modernidade?

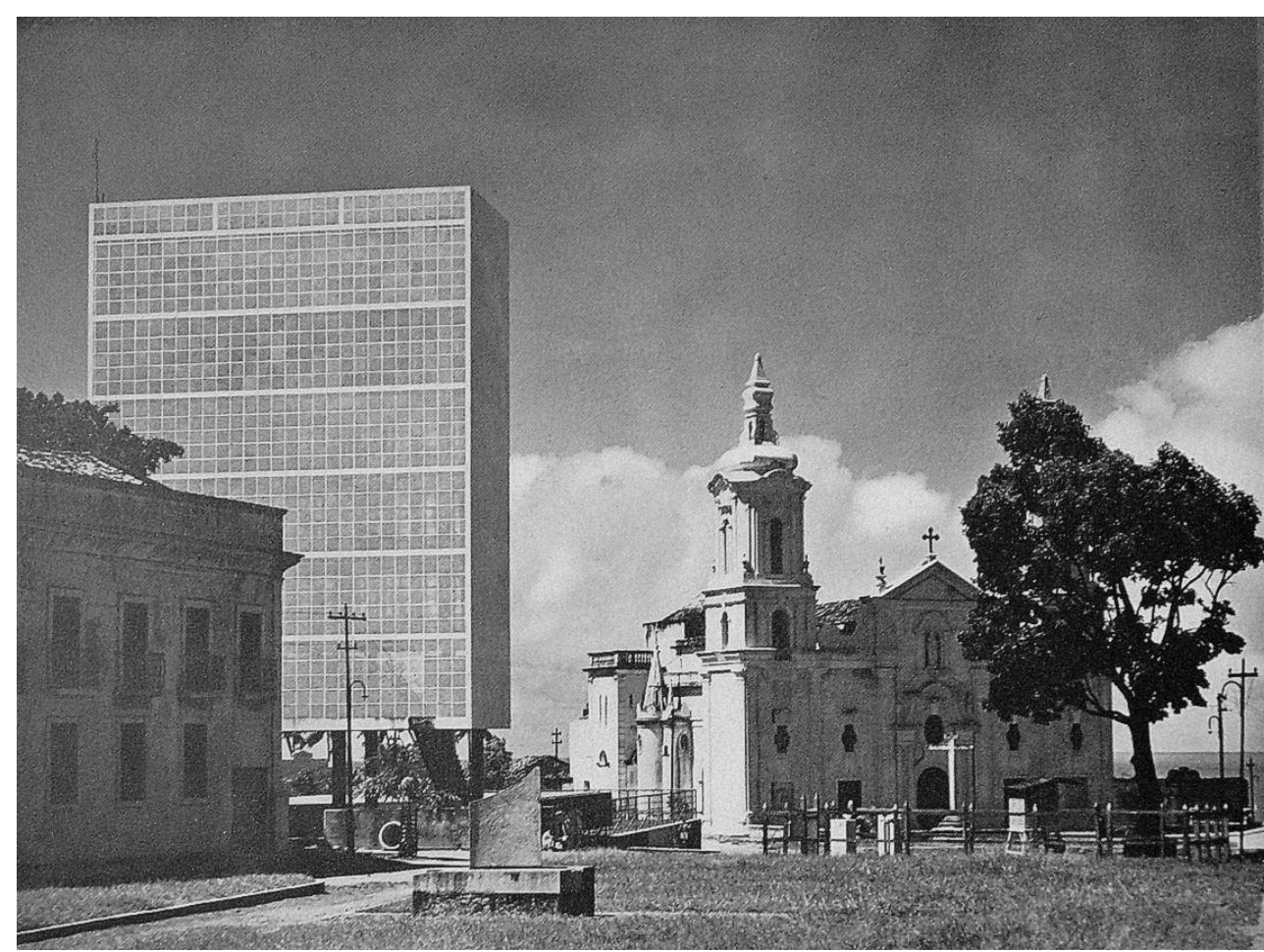

Figura 4.03: torre de água, Olinda; como lembra Goodwin, "the precise and beautiful tower is rather fake only part it is actually used as a tank"

Fonte: P. Goodwin, Brazil Builds, 1943, p.158.

38 L. Costa, A situação do ensino das Belas-Artes, In Depoimento de uma geração, 2003, p.58; Idem, Razões da nova Arquitetura, In Depoimento de uma geração, 2003, p.39-52.

${ }^{39}$ De resto, o episódio de renovação que se desenrolou no Recife como um todo é apenas assinalado. 
Um breve parêntese: merece discussão também a aparente força autoexplicativa da imagem da torre-d'água de Olinda como uma síntese e símbolo da ousadia e dos avanços formais do período heróico da arquitetura modernista no Brasil. A imagem, quer com o cruzeiro em primeiro plano ou a igreja em segundo, parece dispensar maiores considerações, tanto no texto de Mindlin quanto num mais contemporâneo, como o de Sylvia Ficher e Marlene Acayaba.

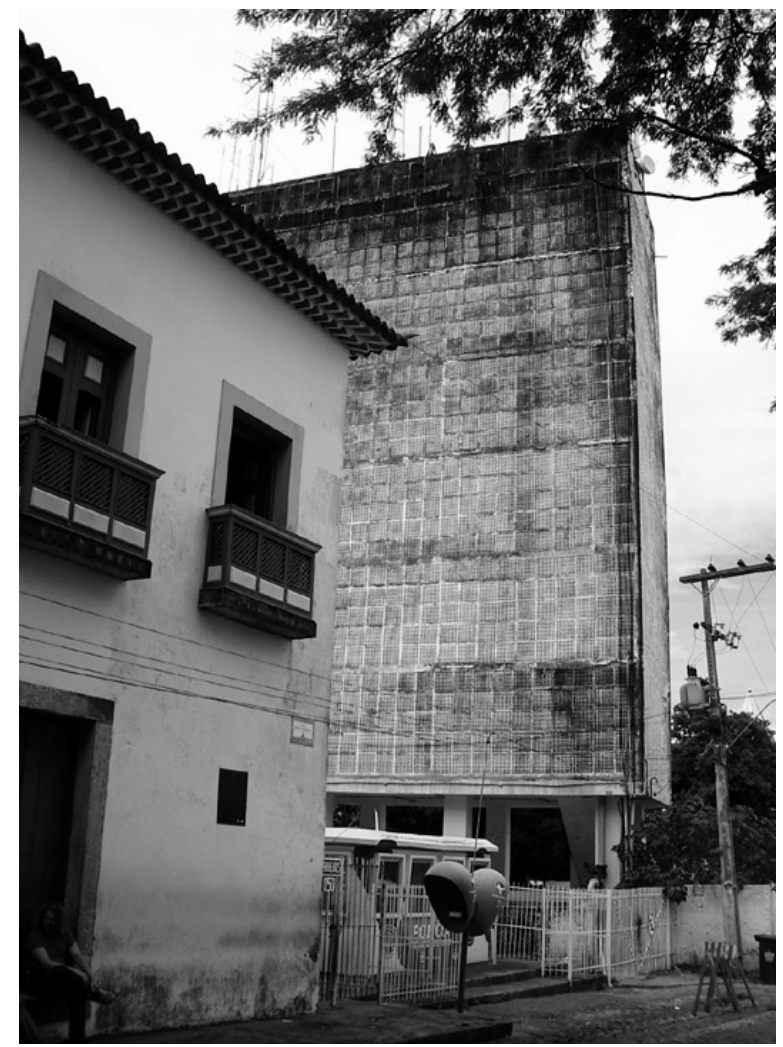

Figura 4.04: foto recente da Torre D’água de Olinda, numa perspectiva que enfatiza a relação de significação do projeto modernista em contraste ao prédio antigo - o que revela muito do interesse do olhar que recorta, no caso, o enquadramento do fotógrafo, e não necessariamente uma situação de contraste acerbo. Fonte: G. A. F. Dantas, maio de 2006.

Embora não explicitamente, a leitura de Goodwin aponta para o ambiente familiar traduzido na casa, no modo de viver tradicional:

Um isolamento exclusivista foi sempre o traço acentuado das famílias latinas. Constitui uma das diferenças constantes e fundamentais entre os Estados Unidos e os paises latinoamericanos. Talvez uma das razões para a aceitação franca e entusiástica dos quebra-luzes, desde as simples rótulas até o tipo 
mais complicado, seja justamente esse isolamento retraído da casa que os brasileiros mantiveram durante séculos. ${ }^{40}$

O vínculo estabelece-se quase que naturalmente dentro da linearidade da cronologia - textual e fotográfica. Uma permanência cultural praticamente sem ruptura que seria apropriada e renovada pela nova arquitetura. Não se deve esquecer, contudo, que o tema do isolamento quase oriental das famílias brasileiras, e das mulheres em especial, constituiu uma representação constante dos viajantes entre o final do século XVIII e o XX - para estabelecer metros civilizacionais comparativos (a mulher não mais restrita à vida íntima seria um sinal de evolução, como enfatizaria o inglês H. Koster na década de 1810, e.g), como foi apontado anteriormente. Tema que seria também rediscutido pelos "intérpretes" do Brasil, como Gilberto Freyre, ao longo do século XX.

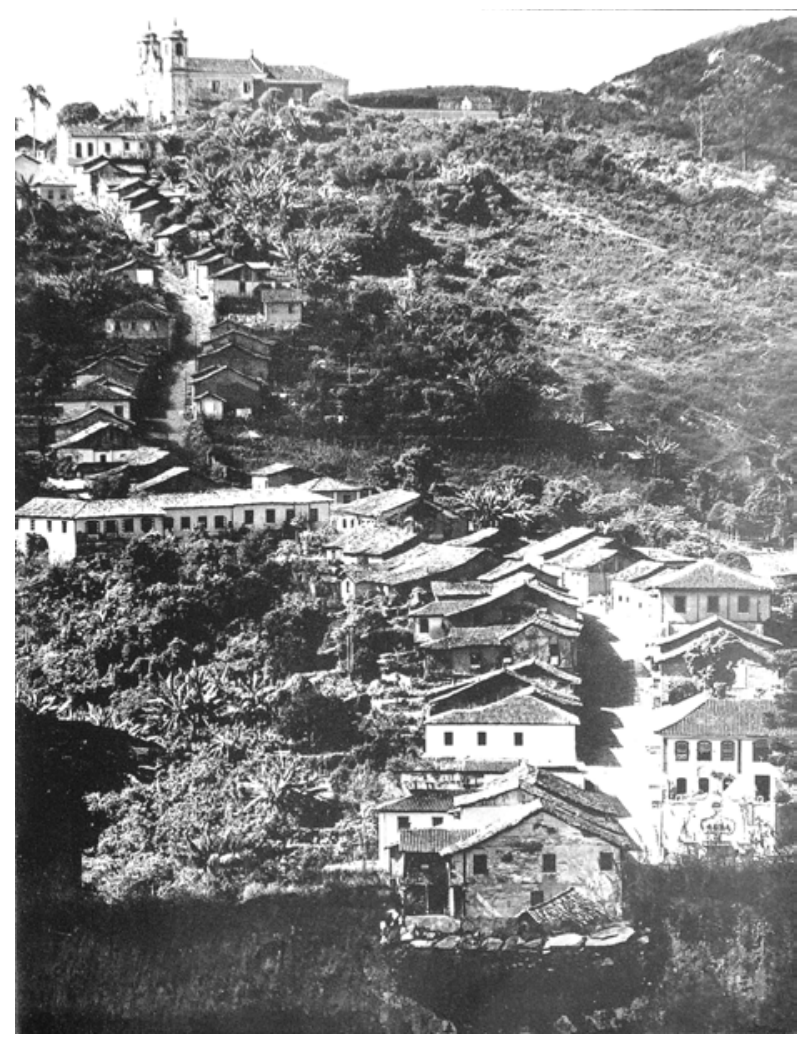

Figura 4.05: caminhos tortuosos de Ouro Preto até a Igreja de Santa Ifigênia

Fonte: P. Goodwin, Brazil Builds, 1943, p.57.

${ }^{40}$ Goodwin, P. Brazil Builds, 1943, p.98. 


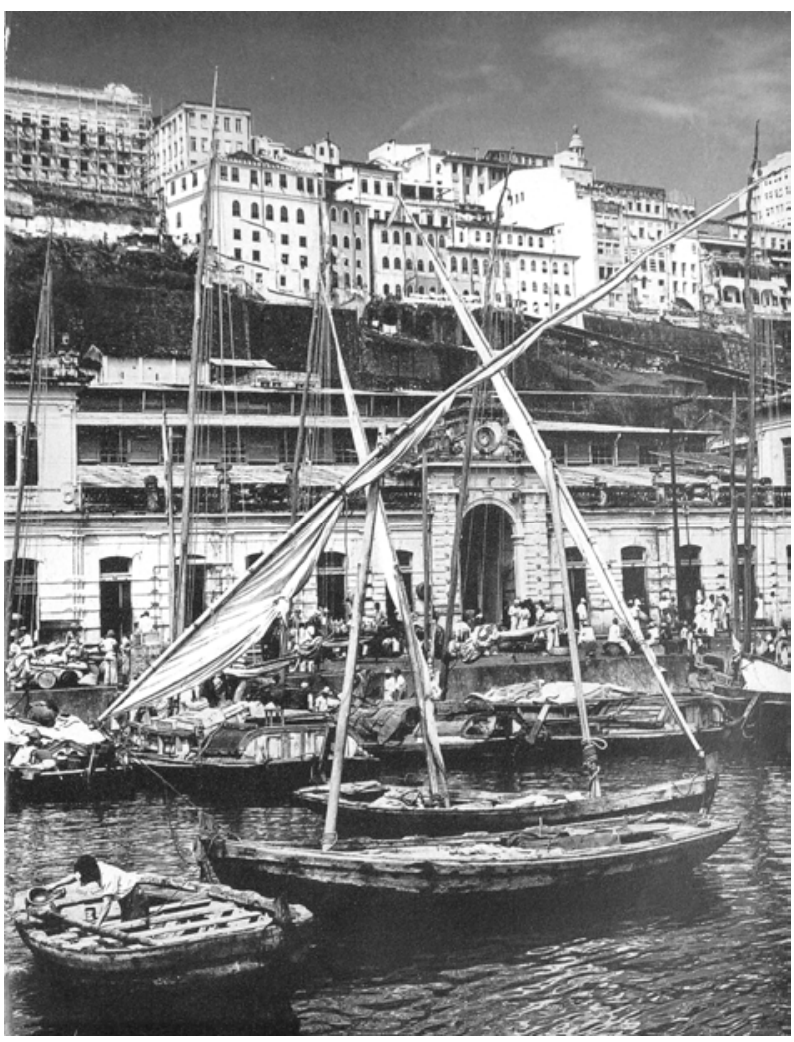

Figura 4.06: Salvador

Fonte: P. Goodwin, Brazil Builds, 1943, p.45.

Em relação ao passado das cidades, há uma pequena pista que é revelada pelo que não considera. Ao falar sobre o urbanismo, Goodwin ressalta que nesse campo São Paulo foi também "bandeirante" (contudo, deve-se notar que o uso da representação deve-se à tradução). Referindo-se ao Plano de Avenidas do engenheiro Prestes Maia, afirma que "aí surgiram os primeiros grandes planos de origem oficial". ${ }^{41}$ Por contraposição, não houve portanto planejamento urbano anteriormente no Brasil.

Mindlin considera seu livro como uma continuação da narrativa de Goodwin, embora o texto e trajeto iconográfico logo adquiram autonomia frente ao tempo decorrido entre uma e outra publicação. Sua análise é também mais erudita e abrangente, apoiando-se numa série de estudos sobre o passado colonial. Robert Smith, Gilberto Freyre, Wasth Rodrigues, o material da revista do SPHAN como um

${ }^{41}$ Goodwin, op.cit., p.94; o texto original é: "São Paulo will be found to have lead in town-planning, first in importance of government-inspired projects". 
todo e principalmente Lucio Costa. A este, inclusive, assim como a Mário Barata e Mário Pedrosa, dentre outros, agradece pela leitura e correção do texto. ${ }^{42}$

Seguindo o recorte específico proposto para este capítulo, Mindlin inicia sua leitura sobre as cidades no Brasil apontando o ímpeto da obra civilizatória da colonização portuguesa: em menos de um século de vilarejos se fizeram cidades, "construídas, tanto quanto possível, à maneira portuguesa". ${ }^{43} \mathrm{O}$ que significa esse construir-se à portuguesa? Cabe acompanhar a longa citação, que reverbera leituras de Freyre e a representação corrente sobre a cidade colonial:

As cidades cresceram de uma maneira bastante desordenada em torno das igrejas, geralmente situadas nos pontos mais elevados. As ruas e becos eram sinuosos e irregulares, evocando uma longínqua influência mourisca. Embora acompanhassem melhor a topografia que as cidades de origem espanhola do resto da América do Sul e da América Central, com seu monótono traçado ortogonal, não revelavam mais do que um esboço de urbanização. Ainda assim, limitações graduais começaram a restringir a o individualismo total da "casa grande". A rua, que no começo nada mais era que um espaço livre em torno da "casa grande" e seus anexos, começou a impor restrições, no interesse da comunidade.

Afasta-se de uma valoração tão-somente negativa da falta de planejamento. Contudo, há uma confusão aqui - ou generalização totalizadora - entre a estrutura físico-espacial da casa-grande e a da cidade. A análise do mundo rural passa sem restrições à análise das transformações nas cidades. Partindo dos "documentos baianos" compulsados por Robert Smith, Mindlin continua o texto, mostrando os esforços de circunscrição, na esfera da cidade, do despotismo privado que marcavam as relações sociais agrárias:

Já antes do fim do século XVII, a legislação municipal da Bahia, por exemplo, procurava disciplinar o egocentrismo do proprietário, obrigando-o a alinhar sua casa com a dos vizinhos e combatendo a tendência a exagerar na saliência dos balcões e a construí-los demasiadamente baixos, o que representava uma ameaça à cabeça dos passantes. ${ }^{44}$

\footnotetext{
${ }^{42}$ Cf. Mindlin, op.cit., "nota do autor", p.22.

43 Ibidem, p.23.

${ }^{44}$ Ibidem.
} 
Enfatiza assim o caráter utilitário, condicionado às circunstâncias geográficas e materiais, na construção e organização das casas e, de maneira geral, das cidades. Contudo, e mesmo assim, Mindlin escreve depois, quando aborda os problemas decorrentes do "crescimento descontrolado das cidades", que a despeito dos éditos reais trazidos no primeiro século de colonização e do fato de Recife ter sido pavimentada antes de Paris, "não há nenhum registro histórico de planejamento urbano em larga escala no Brasil”. O exemplo da solução empírica parece não servir - aos olhos contemporâneos. E repete: "nunca houve, nos tempos da colônia ou do Império, nenhuma tentativa consistente de planejamento urbano". ${ }^{45}$

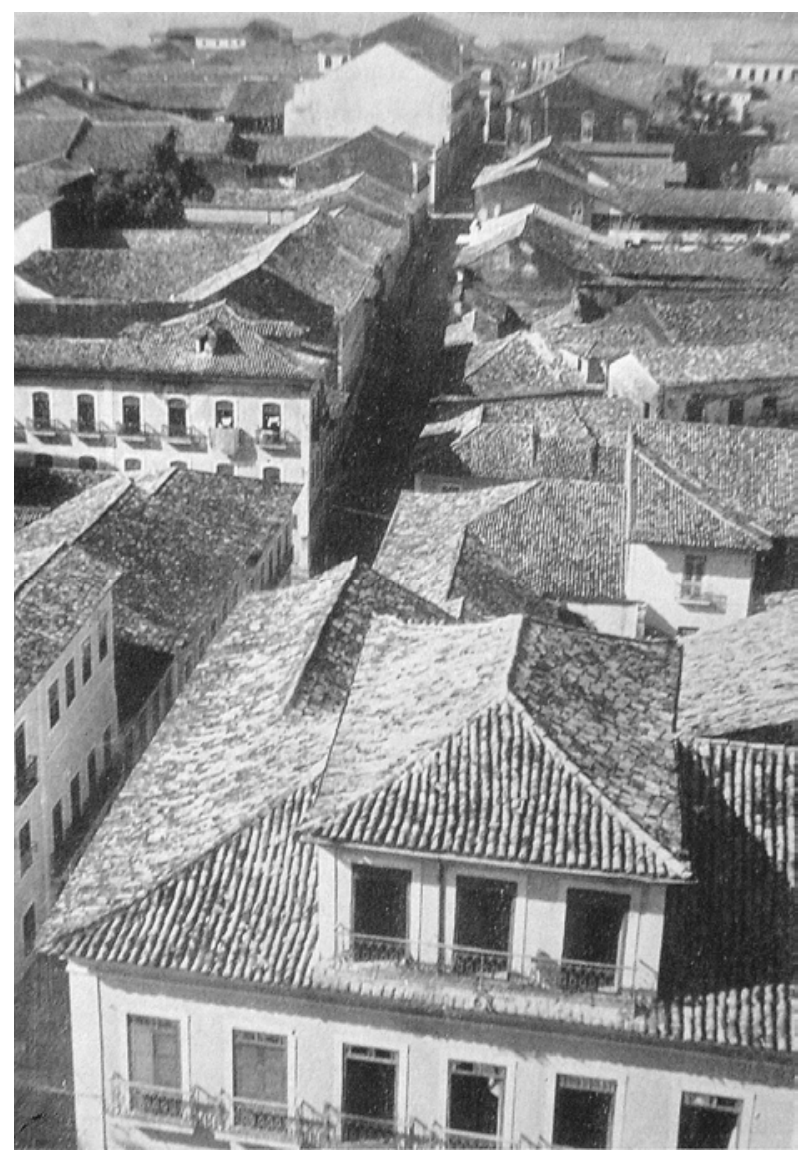

Figura 4.07: antigos telhados do casario de São Luis Fonte: H. Mindlin, Modern Architecture in Brazil, 1956, p.05.

45 Ibidem, p.29. 


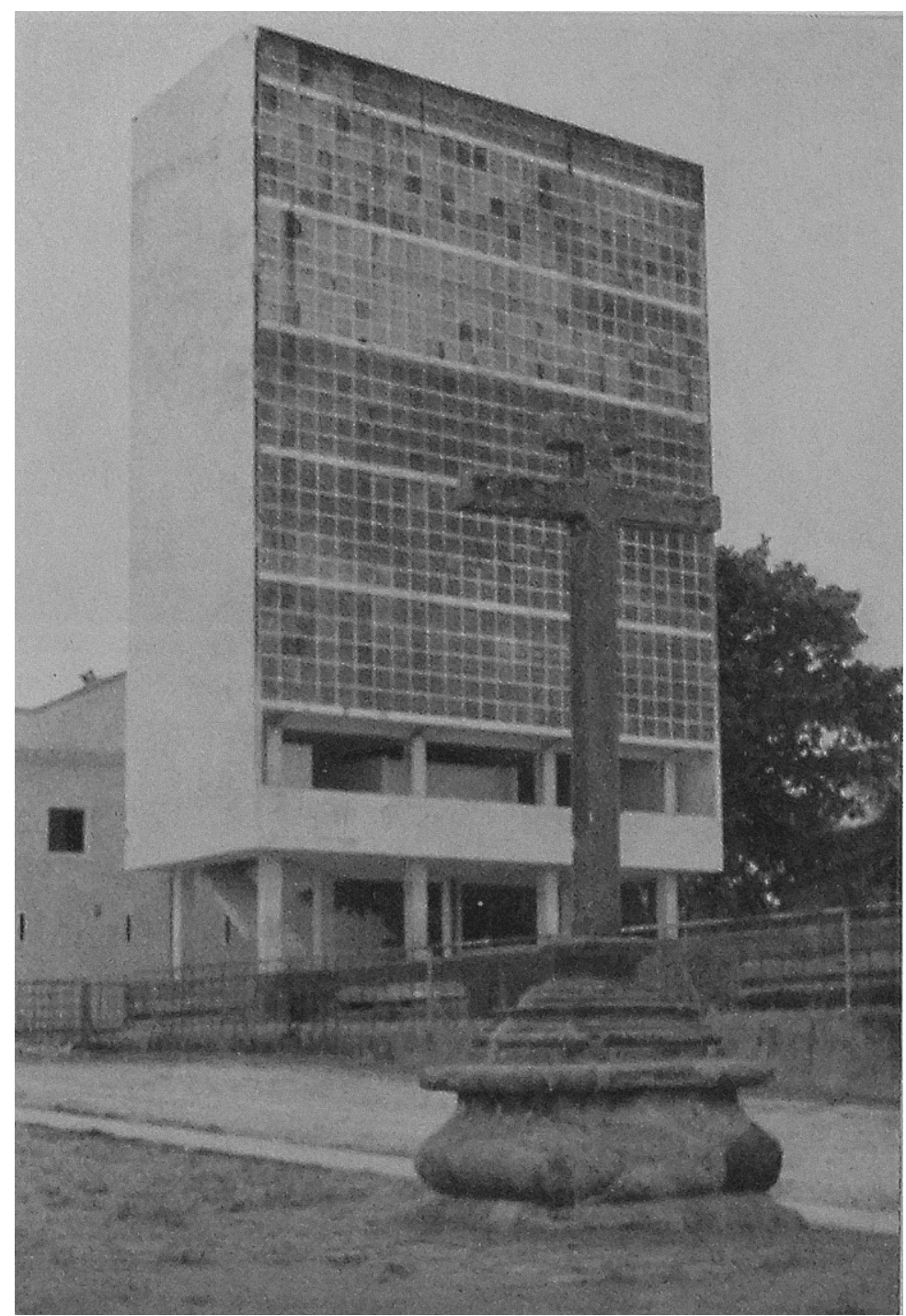

Figura 4.08: torre de água de Olinda (projeto de Luiz Nunes e Fernando Saturnino de Brito), 1937; vista a partir do cruzeiro.

Fonte: H. Mindlin, Modern Arcbitecture in Brazil, 1956, p.05.

A preocupação com os efeitos perniciosos da falta de planejamento - aqui contudo Mindlin se refere não ao passado colonial e imperial, mas à falta de ação no século XX, quando os problemas urbanos se agravaram - o leva a tomar como exemplo uma série de ações urbanísticas, todas no Rio de Janeiro, que foram desastrosas do ponto de vista da preservação do patrimônio. O desmonte do Morro do Castelo, e.g., era um "exemplo de coragem no trato dos problemas do planejamento urbano". Da mesma forma o seriam tanto a abertura da Avenida Presidente Vargas quanto o desmonte do Morro de Santo Antônio. ${ }^{46}$

46 Ibidem, p.30. 
Não é por acaso então que seriam exatamente esses três casos que Bruand recuperaria, como exemplo negativo, ${ }^{47}$ para abordar as dificuldades na relação passado e presente, tradição e modernidade. Episódios significativos de destruição da malha tradicional e secular - estrutura material de suporte da memória e da história da cidade do Rio de Janeiro. Episódios, ademais, cujos processos iniciais remontavam em mais de um século e cuja significância se compunha de múltiplas tramas e investidas.

\section{3 estudos sobre arte e arquitetura colonial}

Em meio às referências mobilizadas para a construção dessas narrativas, os trabalhos de Robert Smith foram praticamente uma constante. Desde os anos 1930, o pesquisador norte-americano vinha produzindo investigações extensivas e eruditas sobre arte e arquitetura no mundo moderno luso - compreendendo as colônias e, assim, especialmente o Brasil. Mais ainda, Smith parece ter desempenhado um claro papel de divulgador da produção dos estudos e pesquisas sobre esse tema para o meio acadêmico norte-americano por meio de dezenas de resenhas, sobretudo na Hispanic American Historical Review, como aquelas destinadas às pinturas de Portinari, à publicação do livro de G. Freyre sobre a presença de Vauthier em Recife, ao livro de Morales de Los Rios Filho sobre Grandjean de Montigny, assim como aos dicionários inglês-português, à gastronomia e às fontes de pesquisa diversas, dentre várias outras. ${ }^{48}$ Ademais, foi o responsável pela compilação sobre Brazilian Art para os primeiros Handbooks of Latin American Studies.

Ao lado de Manoel S. Cardoso e Alexander Marchand, seria um dos pioneiros nos estudos sobre o Brasil e sobre a América Portuguesa no âmbito acadêmico dos Estados Unidos. Ocuparia um lugar institucional de autoridade sobre o tema, em

\footnotetext{
47 Bruand, op.cit., p.334-337.

48 Citamos aqui, dentre os vários artigos aos quais tivemos acesso, as resenhas do início dos anos 1940, como: R. C. Smith, jr., The Art of Candido Portinari, The Bulletin of the Museum of Modern Art, oct. 1940, p.10-12; Idem, Review [untitled, sobre Um engenheiro francês no Brasil, de G. Freyre], The Hispanic American Historical Review, aug. 1942, p.539-541; Idem, Review [untitled, sobre Grandjean de Montigny e a evolução da arte brasileira, de Adolfo Morales de Los Rios Filho], The Hispanic American Historical Review, aug. 1942, p.536-537; Idem, Review [untitled, sobre Portuguese: A Handbook of Brazilian Conversation, de Margarida F. Reno], Hispania, Dec. 1943, p.509-510; Idem, Review [untitled, sobre Variações sobre a gastronomia, de Paulo Duarte], The Américas, Jan. 1945, p.385-386. Registre-se que essa tarefa de divulgação, comentário e discussão da produção sobre o tema permaneceu até o final de sua vida acadêmicas, nos anos 1970.
} 
especial sobre arte e arquitetura do Brasil colonial e de Portugal, a partir dos anos 1930 - quando, em relação ao tema da América Latina, predominavam quase hegemonicamente os estudos sobre a América Hispânica. ${ }^{49}$ Autoridade derivada certamente da formação e erudição de Smith, que lhe permitia transitar pelos documentos originais em português e pelos relatos (em francês, espanhol e alemão) dos diversos viajantes que passaram pelo Brasil, fonte que utiliza com freqüência para reconstruir (literariamente) paisagens arquitetônicas das cidades luso-brasileiras até o início do século XIX, assim como as impressões, representações, significados simbólicos, processos materiais de construção, etc.

Autoridade que deriva também dos esforços institucionais para expandir os estudos sobre a parte portuguesa da América Latina. Se, por um lado, a crescente produção sobre a América Hispânica permitira a constituição de disciplinas (como a criada em Berkley, em 1894) ou mesmo a elaboração de obras de síntese (como o livro de E. G. Bourne em 1904) na virada para o século XX, por outro, não se poderia falar em especialistas sobre a América Portuguesa até finais dos anos 1930, início dos anos 1940. Tampouco havia uma agenda sistemática de pesquisas e estudos, como se expressa, e.g., na produção relativa irrisória sobre o tema entre 1918 e 1945. A renovação das discussões panamericanistas e o crescente peso geopolítico do Brasil a partir do contexto da Primeira Guerra Mundial ajudam a explicar a mudança nesse quadro. Argumentava-se, ademais, que as bibliotecas norteamericanas possuíam coleções e uma bibliografia suficiente para estudar o Brasil. Não se pode esquecer que a vasta e especializada biblioteca do historiador de ofício e diplomata Oliveira Lima já estava disponível em Washington. O espaço dedicado ao Brasil foi se tornando crescente nos Handbooks of Latin American Studies, editados desde 1935. Assim, em 1945, B. William Diffie publicaria importante estudo, Latin American Civilization: colonial period, que incluiria o Brasil dentro do quadro mais geral de compreensão. ${ }^{50}$ No mesmo período, dentro do programa das Nações Unidas, o livro sobre o Brasil editado por Lawrence Hill, reunindo contribuições de autores brasileiros e brasilianistas, como Manoel Cardozo, Mario de Andrade, Frederic William Ganzert, Samuel Putnam, Francisco Venâncio Filho, Arthur Ramos, entre

\footnotetext{
${ }^{49}$ A. J. R. Russel-Wood, United States scholarly contributions to the historiography of colonial Brazil, The Hispanic American Historical Review, nov. 1985, p.694-696.

${ }^{50}$ Russel-Wood, op. cit., p.687-693.
} 
outros, considerava-se como o primeiro a abarcar diversas esferas da história do Brasil. ${ }^{51}$ A produção de Robert Smith pode ser entendida também nesse contexto, quer como pesquisador que publicava nos periódicos panamericanistas (escreveu sobre São Luiz do Maranhão para o primeiro número de The Pan American Traveler, e.g., além de vários artigos para o Bulletin of Pan American Union), quer como editor colaborador dos citados Handbooks.

Em longo artigo sobre a arquitetura colonial de Minas Gerais, publicado em The Art Bulletin, Smith argumentaria que o Brasil, das antigas colônias européias, foi onde se apresentou de forma consistente uma relação direta com a arquitetura da metrópole. Sem ter que enfrentar um clima muito diverso ou severo que exigisse alterações significativas nas condições materiais de produção, acabaria se configurando um único estilo luso-brasileiro (a single Portuguese-Brazilian style) ao longo do processo de colonização. Desde os primeiros estabelecimentos em São Vicente e Igarassu até as construções urbanas do projeto político centralizador do século XVIII sob Pombal, a arquitetura seria completamente portuguesa, quer nas cidades costeiras, mais influenciadas pela tradição da Corte, quer nas cidades do interior, onde teria florescido a tradição nativa Portuguesa do meio rural. ${ }^{52}$

Smith pouco trata das cidades neste artigo. Primeiro, porque a ênfase estava na leitura da arquitetura religiosa. Em segundo, pela consabida dificuldade em obter relatos de uma região sob estrito controle da Coroa. Depois do livro de André João Antonil (Cultura e Opulência do Brasil por suas drogas e minas, de 1711), publicado em Lisboa e logo suprimido pelas autoridades reais, apenas se voltaria a publicar textos sobre a região das Minas Gerais no início do século XIX, pelo relato dos viajantes. A leitura de John Mawe, D’Orbigny, Alexander Claudcleugh, Reverendo R. Walsh, F. Denis, Hermann Burmeister e, principalmente, Saint-Hilaire - "one of the most observant of the nineteenth century visitors to Brazil" - testemunhariam uma região já em decadência. ${ }^{53}$

Esses relatos serviam de contraponto a sua própria observação in loco. Os resultados que apresentava então eram parte das pesquisas conduzidas no Brasil em

\footnotetext{
${ }^{51}$ L. Hill (ed.), Brazil, 1947.

${ }^{52}$ R. Smith, The colonial architecture of Minas Gerais in Brazil, The Art Bulletin, jun.1939, p.110-111.

53 Ibidem, p.113-114, 126 e nota de rodapé 33.
} 
1937, sob os auspícios da American Council of Learned Societes. Nessa confluência surgiam algumas tentativas de análise do espaço urbano observado:

Monsieur de Saint-Hilaire has complained that Ouro Preto possessed no public parks or promenade. Yet this was the only town in Minas Gerais in which there is evidence of definite Baroque town planning [sic]. The laying out of squares and broad avenues in such a mountainous region, where towns grew up wherever there was gold, regardless of the site's relation to other factors, was naturally a difficult undertaking. ${ }^{54}$

Uma terceira razão, pode-se especular, estaria no desconhecimento da vasta iconografia produzida pelos portugueses, mesmo no século XVIII. Smith, nesse momento, já conhecia algumas pinturas de Frans Post (sobre o qual escrevera para The Art Quartely, em 1938, em artigo intitulado "The Brazilian landscapes of Frans Post") além do importante trabalho de Joaquim de Souza Leão (Frans Post: seus quadros brasileiros, 1937). Mais de dez anos depois, Robert Smith começaria a discutir as plantas e mapas que pôde compulsar, como a da cidade de Mariana, de 1745, que encontrara no Arquivo Militar do Rio de Janeiro.

54 Ibidem, p.147; grifos nossos. 


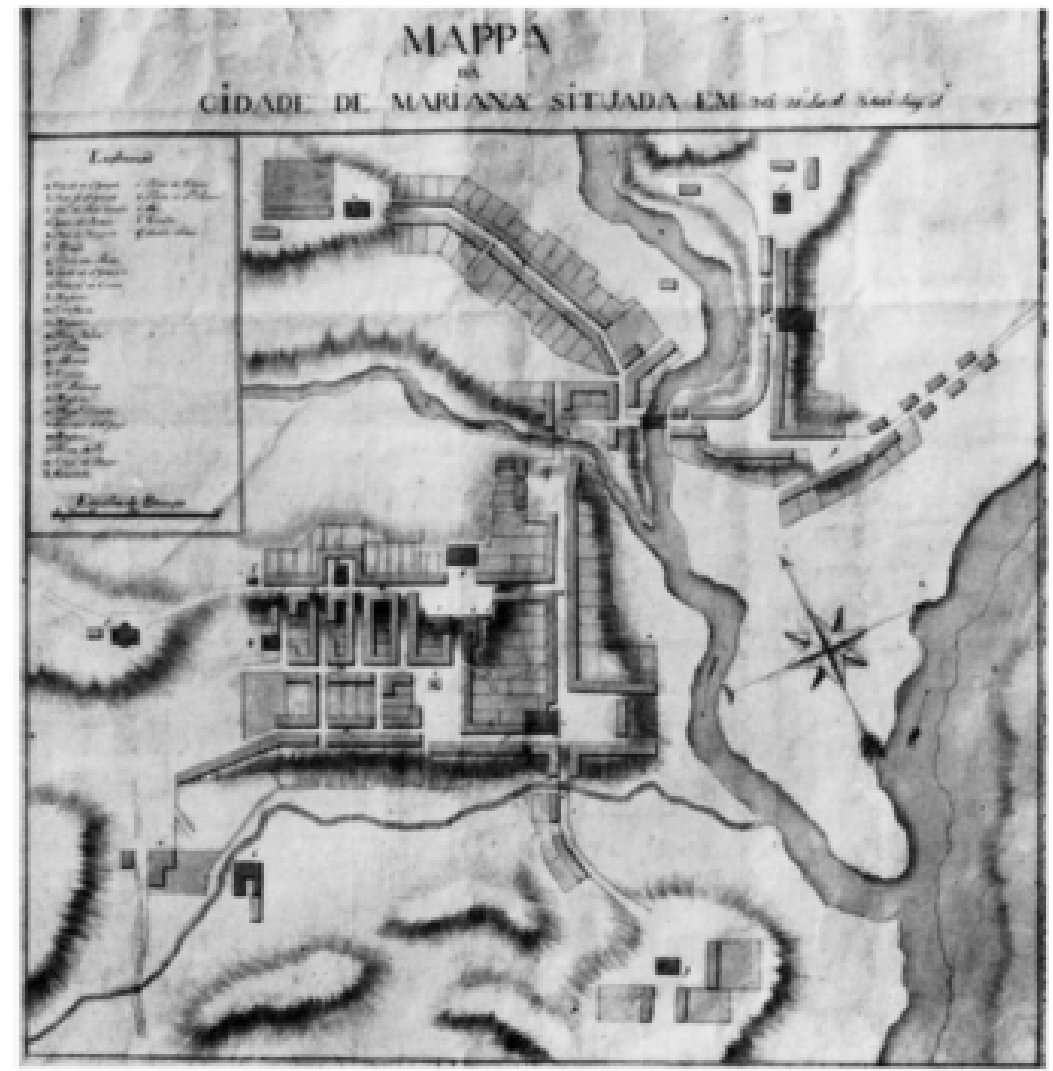

Figura 4.09: Mariana em mapa de 1745; o plano de expansão, feito pelo eng. militar Jose Alpoim, seria considerado por Smith como possivelmente o primeiro exemplo de uso da grelha retangular no Brasil. Fonte; R. C. Smith, Colonial towns of Spanish and Portuguese, $J S A H, 1955$.

Mesmo em artigos da década de 1950, Smith não apresenta grandes avanços em pesquisas iconográficas sobre a cartografia produzida por portugueses, holandeses, franceses e ingleses sobre a América Portuguesa. Essa era uma questão generalizada, na verdade, que começaria a ser enfrentado por pesquisadores como Mario Chicó, em Portugal, e Nestor Goulart Reis, no Brasil, no final da década e ao longo dos anos 1960.

Robert Smith discutiria a cidade colonial brasileira em, pelo menos, dois textos, ambos publicados em 1955: como introdução ao livro sobre a arquitetura colonial na Bahia e em artigo mais minucioso para The Journal of the Society of Architectural Historians (JSAH). ${ }^{55}$ Percebe-se que ambos os textos estão relacionados, partem do mesmo fundo-comum de pesquisa, embora o primeiro, por seu próprio

55 R. C. Smith, Arquitetura colonial [as artes na Bahia - I Parte], 1955; Idem, Colonial towns of Spanish and Portuguese, The Journal of the Society of Architectural Historians, dec. 1955, p.03-12. 
caráter introdutório, seja muito breve: apenas três páginas cujas frases constituíram, pode-se arriscar afirmar, formulações sedutoras, sintéticas, representações strictu sensu - que conformaria lugares-comuns do debate sobre o tema. ${ }^{56}$

Mais do que a questão do idioma mais acessível, possivelmente o "sucesso" do primeiro texto tenha vindo dessa sedução das palavras. Não à toa, provém dessa introdução a frase lapidar que a "ordem era ignorada pelos portugueses como assinalavam deliciados os viajantes". ${ }^{57}$

Lapidar e reveladora do conjunto de referências que vinham estruturando as pesquisas e parte das análises de Robert Smith sobre arte e arquitetura colonial no Brasil. As descrições dos viajantes conformam um suporte documental essencial para a sua leitura, como já se percebia nos artigos dos anos 1930. Mas, deve-se fazer a ressalva: não se pretende afirmar que o trabalho de Smith resumia-se a análise da arquitetura e das cidades luso-brasileiras pelo relato dos viajantes tão-somente. Como historiador da arte, primordialmente, a análise do objeto era essencial. O objeto como "presença absoluta", como diria Argan, que não prescinde, claro, das leituras e significações que se sobrepõem ao longo da história, mas que, enfim, resiste/existe como materialidade. Investigar essa materialidade pressupunha, depreende-se dos textos de Robert Smith, um esforço constante de análise comparativa dos processos civilizacionais, dos desejos que os impeliam assim como de seus limites. Daí, portanto, o uso constante e inescapável dos relatos viajantes, assim como da compilação de documentos como aqueles organizados por Paulo Vilhena. Assim, Smith abriria o texto afirmando que

Os portugueses estabeleceram no Brasil, quase intacto, o mundo que haviam criado na Europa. A melhor comprovação oferece a cidade da Bahia em si mesma. Em quase 215 anos, de 1549 a 1763, durante os quais gozou do privilégio de ser a primeira metrópole lusitana no novo mundo, tornou-se a Bahia uma réplica fidelíssima de Lisboa e do Porto (...).

[como ambas cidades], de acordo com o uso português, a Bahia foi fundada sobre uma escarpa alta, dominando larga extensão de água. A exemplo de ambas, para defesa, foi cercada de muros com torres e portas entremeadas com fortes. Os melhores sítios, o alto das colinas, como em Portugal foram reservados às igrejas e

\footnotetext{
${ }^{56}$ Ao longo do livro, há considerações esparsas à estrutura e paisagem urbanas em meio à discussão sobre arquitetura civil e religiosa da cidade de Salvador.

${ }^{57}$ R. C. Smith, Arquitetura colonial, 1955, p.12.
} 
conventos, aos edifícios públicos e solares, ao passo que o comércio funcionava em baixo ao longo do cais. Havia assim duas cidades, uma alta e outra baixa, existindo na Bahia como na terramãe o problema constante da comunicação. Esta fazia-se por uma série de caminhos tortuosos tão estreitos e ingremes que o tráfego de veículos era quase impossível (.....58

A sucessão de palavras que evocam a falta de ordenamento, de controle, de racionalidade enfim, se sucedem.

As suas ruas, ironicamente chamadas "direitas", eram tortas e cheias de altibaixos, as suas praças de ordinário irregulares, as casa agarravam-se às vertentes alcantiladas das colinas em torno de uma teia de caminhos escuros, escadas e passadiços, (...). desta sorte, em 1763, quando deixou de ser a capital do Brasil era a Bahia uma cidade tão medieval quanto Lisboa na véspera das grandes reformas de Pombal. Nada inventaram os portugueses no planejamento de cidade em países novos. Ao contrário dos espanhóis, que eram instruídos por lei a executar um gradeado regular de ruas que se entrecruzam em torno de uma praça central, os portugueses não mantinham regras, exceto a antiga, da defesa através da altura. Suas cidades cresceram pela vinculação gradual de núcleos isolados, formados pela fundação individual e arbitrária de capelas, casas ou mercados. A posição desses edifícios ditava as trajetórias irregulares seguidas pelas ruas que os uniam..$^{5}$

Ruas inclinadas, faixas estreitas de terra para ocupação, áreas atravancadas, vias que descem e sobem rapidamente, de maneira abrupta, caminhos que vagueiam entre torres e telhados "pitorescos", assim se comporia a "clássica mise-em-scène luso brasileira, o fundo dramático da arquitetura primitiva". Características que partilhava com vilas e cidades como Olinda, Rio de Janeiro e as mineiras do século XVIII, mas Salvador era a suma da cidade luso-brasileira. ${ }^{60}$

O texto mantém a perspectiva de pensar a arte e a arquitetura no Brasil como parte de um mesmo sistema cultural - o mundo luso -, embora atento às particularidades, às adaptações, às transformações. Smith alinhava-se assim ao "programa" anunciado por Gilberto Freyre já no primeiro número da Revista do

\footnotetext{
58 Ibidem, p.11-12.

${ }^{59}$ Ibidem, p.12.

${ }^{60}$ Ibidem, p.13.
} 
SPHAN, o esforço de pesquisa para compreender a "unidade luso-brasileira" ou, mais ainda, como sugeriria, "luso-afro-brasileira". ${ }^{61}$

A sedução de palavras desse texto seria sopesada no artigo para o JSAH, inclusive pela própria extensão do texto acadêmico mais longo. Antes de mais nada, Smith lembraria que das seis nações que se aventuraram em empreendimentos colonizadores entre 1500 e 1700, apenas os espanhóis teriam criado vilas e cidades a seguindo um padrão regular e invariável, baseado no traçado ortogonal que, por sua vez, remetia-se à retomada da prática da Antiguidade de fundar cidades - base para, em autores como Filarete e Alberti, articular a noção de cidade ideal. Esse padrão de ocupação teria sido, assim, repetido por toda a América do Sul hispânica. ${ }^{62}$

Os portugueses, ao contrário, não teriam trabalhado com a noção de ordem e plano. Como diria:

That plan in fact was not a characteristic of the colonial settlements of Brazil. At no time did the Portuguese, who discovered the country in 1500 and held it until 1822, provide a code of rules for urban development. Their cities grew without being planned in a kind of picturesque confusion that is as typical of Luso-Brazilian cities as order and clarity are typical of the urbanism of Spanish America. ${ }^{63}$

Aqui, a referência direta para construir essa generalização era o livro de Sérgio Buarque, em sua segunda edição, portanto, remetendo-se direto ao novo capítulo 4 “o semeador e o ladrilhador". Os exemplos evocados por Smith são vários para atestar a falta de ordem, desde Rio de Janeiro, Ouro Preto e, principalmente, Salvador. Mais do que qualquer descrição verbal, a iconografia então existente era mais eloqüente para expressar a confusão que reinava, como a do quarteirão do já demolido Morgado de Santa Bárbara, exemplo evocado em vários textos de Smith.

\footnotetext{
${ }^{61}$ G. Freyre, Sugestões para o estudo da arte brasileira em relação com a de Portugal e a das colônias, Revista do SPHAN, n.1, 1937.

62 R. C. Smith, Colonial towns of Spanish and Portuguese, op. cit, p.03-05.

${ }^{63}$ Ibidem, p.06-07.
} 


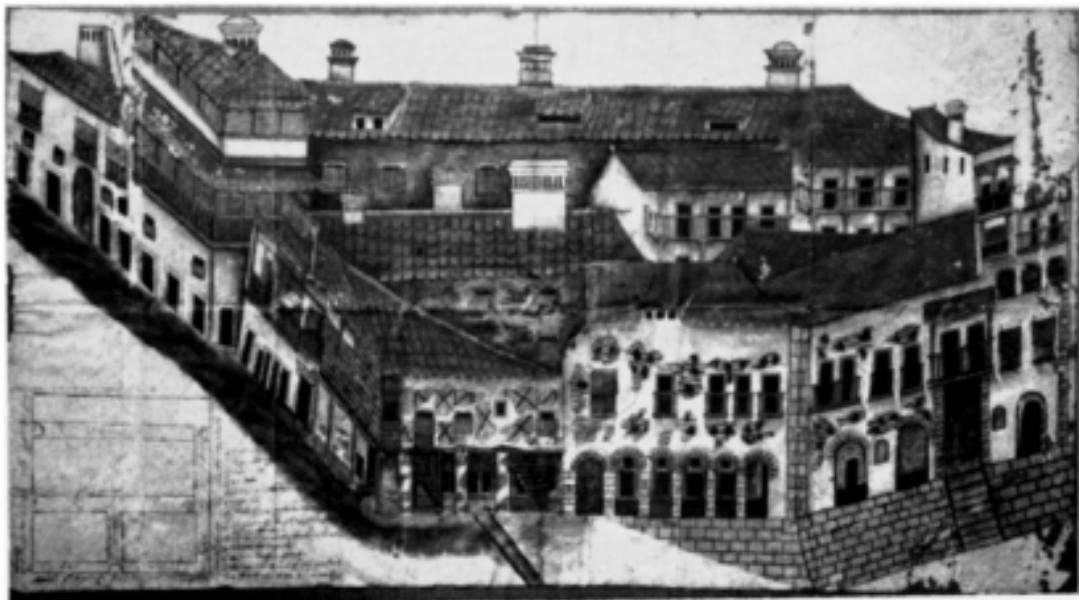

Figura 4.10: Morgado de Santa Bárbara, Salvador, em aquarela do século XVIII. Fonte: R. C. Smith, Colonial towns of Spanish and Portuguese, JS AH, 1955.

Contudo, apesar de todos os problemas derivados da falta de plano - que revelavam a longa permanência dos procedimentos medievais de construção de cidades -, Robert Smith reconhecia que

The gridiron system may have lacked originality but it did have these advantages. It also allowed practically unlimited expansion upon the same plan and provided a stamp of imperial uniformity to a whole colonial development. In Portuguese America, on the contrary, an opposite system almost exclusively prevailed. Settlements were made in rugged coastal areas. They developed without formal plans in strip formation at several levels, with narrow steep streets that rendered any communication difficult. The resulting plans are all different, disordered but picturesque. ${ }^{64}$

A superação dessas leituras - que davam estatuto historiográfico à representação negativa da cidade colonial, demonstrando "materialmente" as imagens de desordem e irregularidade que constituíam entraves atávicos à modernização do Brasil - só seria possível, nas décadas seguintes, com o avanço da pesquisa documental e com a mudança nas próprias chaves de leitura. A irregularidade aparente exigiu um saber técnico refinado que não prescindiu de planos formais e de concepções cujas soluções apontam para outro registro de ordem.

64 Ibidem, p.11. 
CONSIDERAÇÕES FINAIS

IMAGENS E REPRESENTAÇÕES EM UM TEXTO FUNDADOR: "Raízes do Brasil" 
"Não há cidade que pertença a um homem só" [Hêmon a Creonte] Sófocles, Antígona, verso 837

Um texto e uma polêmica permaneceram como leitura subjacente ao longo desta tese. Uma preocupação de fundo, sempre à espreita. Uma preocupação que, como dito na introdução, serviu como ponto de partida ao projeto e que, depois, funcionaria como ponto de inflexão. Agora, servirá como ponto de chegada das voltas desta tese de trama difusa e incompleta, na qual algumas imagens do quebracabeça se formaram, acredita-se, e outras tantas apenas se insinuaram.

Raízes do Brasil é uma pedra angular das interpretações sobre o Brasil e, ao mesmo tempo, uma pedra no caminho para dialogar e problematizar tais interpretações. Livro sedutor, repleto de imagens-sínteses que marcam uma escrita ensaística rigorosa que se embebia nas questões de história social e psicologia, sem perder o "senso agudo das estruturas", Raízes do Brasil tornou-se um texto praticamente inescapável para discutir as representações sobre o Brasil e, mais especificamente aos interesses desta tese, para as representações sobre a cidade brasileira. Imagens-síntese que constroem lugares-comuns, representações, pontos de partida interpretativos e narrativos. A própria oposição entre semeador e ladrilhador é uma dessas imagens. Parecem opor imediatamente Olinda a Lima, Vila Rica a Santiago de Guatemala, Vila Boa de Goiás a Buenos Aires ou Cidade do México.

De fato, reconhece-se e se concorda aqui com a condição de tomar Raízes do Brasil como texto inaugurador de "uma abordagem interpretativa da historiografia urbana brasileira". De uma abordagem tão complexa e sugestiva que gerou polêmicas substantivas sobre o passado colonial e, mais ainda, acabaria se tornando

\footnotetext{
${ }^{1}$ Ibidem, p.249.

${ }^{2}$ Cibele S. Rizek, Os sentidos da cidade brasileira, in VII Seminário de História da Cidade e do Urbanismo, 2002, p.01
} 
um mito. ${ }^{3}$ Mito por que a sua estrutura analítica teria se ossificado numa narrativa a qual não caberia reparos. Concordava-se ou não com seus termos.

Se é certo que a forma do ensaio interpretativo, tradição na qual também bebe Raízes do Brasil, se presta a tais leituras totalizantes, não menos certo é a consideração de que a obra historiográfica de Sérgio Buarque está muito distante de quaisquer esquematismos. ${ }^{4} \mathrm{O}$ próprio autor, em entrevista no início da década de 1980, apontava, ainda que de maneira imprecisa, para a necessidade de reformulação de várias partes de Raízes do Brasil, incluindo o capítulo que interessa a esta tese mais de perto, conforme citado no capítulo $4 .{ }^{5}$ Mas, antes ainda, no prefácio à segunda edição ao livro de 1948 (o texto é datado de junho de 1947), diria que

(...) este livro sai consideravelmente modificado na presente versão. Reproduzi-lo em sua forma originária, sem qualquer retoque, seria reeditar opiniões e pensamentos que em muitos pontos deixaram de satisfazer-me. Se por vezes tive o receio de ousar uma revisão verdadeiramente radical do texto - mais valeria, nesse caso, escrever um livro novo -, não hesitei, contudo, em alterá-lo abundantemente onde pareceu necessário retificar, precisar ou ampliar sua substância. ${ }^{6}$

De fato, há substanciais alterações entre a primeira e a segunda edição; a terceira (1955) - que é, sem maiores reparos, a versão que se lê nas edições mais atuais - também apresentaria novos cortes e acréscimos, enquanto que a quinta estabeleceu em definitivo a organização de notas e a diagramação. ${ }^{7}$ Mas, mesmo com essas alterações, é possível afirmar, como já o fizeram outros autores, que os argumentos centrais permaneceram, ainda que atenuados ou menos enfáticos em alguns trechos ou no todo. ${ }^{8}$

\footnotetext{
${ }^{3}$ Fânia Fridman, Breve história do debate sobre a cidade colonial brasileira, in $A$ cidade como história, 2004, p.44

${ }^{4}$ R. Vainfas, Sérgio Buarque de Holanda: historiador das representações mentais, in Sérgio Buarque de Holanda e o Brasil, 1998.

${ }^{5}$ S. B. Holanda, A revolução subterrânea, Folha de São Paulo, 2004 [1981], p.13.

${ }^{6}$ Idem, Raízes do Brasil, $2^{\text {a }}$ ed, 1948, p.11.

${ }^{7}$ Edgar de Decca, Raízes do Brasil: um ensaio de formas históricas, in Pelas Margens: outros caminhos da história e da literatura, 2000; Robert Wegner, Um autor relê seu livro, in A Conquista do Oeste: a fronteira na obra de Sérgio Buarque de Holanda, 2000, p.53; Francisco Barbosa, Introdução, in Raízes de Sérgio Buarque de Holanda, 1989, p.11. A terceira edição é a que une, pela primeira vez, os textos do debate com Cassiano Ricardo sobre "o homem cordial"

${ }^{8}$ Interessado em discutir a noção de fronteira na obra de Sérgio Buarque, Robert Wegner mapeou duas modificações importantes: a primeira refere-se às ressalvas às teses de Max Weber em $A$ ética
} 
Essa atenção às edições e às mudanças vão além do mero escrúpulo e interesse exegético. O mapeamento dessa inquietação e inconformismo de um autor que lê seu próprio texto implica apontar alguns elementos para entender a própria historicidade do texto e das leituras que foram se sobrepondo.

Afinal, é inegável o lugar central que Raízes do Brasil ocupou e ainda ocupa como um dos textos chaves para entender como se pensou o Brasil ao longo do século XX. No campo disciplinar da história da arquitetura, do urbanismo e da cidade, permaneceu - e, de várias maneiras, ainda permanece - como um dos pólos antagônicos na querela sobre a existência ou não de plano na política urbanizadora dos portugueses para as suas colônias e, em especial, para o Brasil. Serviu de referência definitiva, antes, para Robert Smith e para Yves Bruand, e.g., mas em trabalhos mais recentes ainda é tomado como estrutura argumentativa para falar dos processos de urbanização no período colonial. ${ }^{9}$

Para além do como se leu e das seleções e recortes efetuados da narrativa de Sergio Buarque, é preciso inquirir o próprio texto, seus termos, sua história. É necessário, antes de mais nada, acompanhar as mudanças auto-reconhecidas que Sérgio Buarque operou em seu livro. Há aí chaves fundamentais para entender os objetivos do livro, os interesses que permeiam e que podem ser revelado na sua própria estrutura. Uma das mudanças significativas operada entre as duas primeiras edições reside, precisamente, na estruturação do capítulo que acabaria servindo para consolidar as representações negativas sobre a cidade colonial brasileira.

Advirta-se desde logo que não houve uma partição de um capítulo em dois. A edição original apresentava dois capítulos intitulados "O passado agrário" - o III e o IV, este assumido como uma continuação. A partir da segunda edição, foram

protestante e o espirito do capitalismo; a segunda, a relativização da leitura do peso do iberismo, afastando-se da "explicação genética" determinista original, que poderia dar margens à visadas fatalistas, cf. R. Wegner, op. cit., pp.58-67.

${ }^{9}$ Como, dentre vários, o livro recente de Verena Andreatta (Cidades quadradas, paraísos circulares: os planos urbanísticos para o Rio de Janeiro no século XIX, 2006) o faz, ao discutir o tipo de trama urbana que se desenvolveu desde o século XVI no Rio de Janeiro e que seria tematizado pelos reformadores do século XIX. Dentre vários outros autores que discutem as teses de Raízes do Brasil para iluminar novas questões sobre as características do processo de urbanização do Brasil colonial, deve-se destacar: Beatriz Bueno, Desenho e Desígnio: O Brasil dos engenheiros militares (1500-1822), 2001; Ana de Lourdes da Costa, Salvador, século XVIII: o papel da ordem religiosa dos Beneditinos no processo de crescimento urbano, 2003; e Renato Cymbalista, Sangue, ossos e terras: os mortos e a ocupação do território luso-brasileiro, séculos XVI e XVII, 2006. 
renomeados para "Herança rural" e "O Semeador e o Ladrilhador", respectivamente, “denominações estas que melhor se ajustam aos conteúdos, pelo menos aos conteúdos atuais". Alertando o seu leitor para as mudanças realizadas, Sérgio Buarque diria que essas novas denominações eram parte daquelas "mudanças simplesmente exteriores ou formais agora introduzidas". ${ }^{10}$

$\mathrm{Na}$ verdade, as mudanças foram muito mais substanciais. Como se percebe, a abertura de ambos capítulos permaneceu, mas os textos foram alterados, alguns verbos e substantivos substituídos, fazendo cortes e inúmeros acréscimos. Apenas para ilustrar, registre-se que o capítulo IV original tinha 40 parágrafos e, na edição de 1948, passou a 71 parágrafos (aumento que deriva também da reorganização dos parágrafos, subdividindo alguns em 2, 3 ou mesmo 4 novos, o que melhorou, de fato, a leitura). Tipograficamente, a edição de 1948 introduz também o espaçamento maior entre alguns parágrafos, acentuando a mudança de blocos temáticos dentro de cada capítulo.

O conteúdo é razoavelmente expandido. As longas notas ao capítulo "O Semeador e o ladrilhador" não existiam em 1936, e.g. (as notas são, respectivamente: "vida intelectual na América Espanhola e no Brasil”, "a língua geral em S. Paulo", “aversão às virtudes econômicas" e o mais curto, conquanto muito significativo, “natureza e arte”). A propósito, a nota 2 é exemplar do ofício de um historiador amadurecido, que inquire com rigor e perspicácia as fontes, apontando limites, legitimidades e possibilidades de usos de diversas fontes para investigar a tese de que o tupi seria corrente no uso civil e doméstico na província mesmo durante o século XVIII. $^{11}$

Há ademais nessas notas argumentos que aprofundam a discussão que ajuda a entender o lugar original dos capítulos III e IV. Assim, não se pode olvidar que o capítulo "O passado agrário" fica entre um capítulo (II - "Trabalho e aventura") que argumenta que os portugueses instauraram no Brasil uma "civilização de raízes rurais" e outro ( $\mathrm{V}$ - "O homem cordial") que descreve o que seria o traço fundamental da "mentalidade" do brasileiro - a cordialidade -, plasmada em tal contexto de primazia da vida rural em oposição à miséria urbana; assim, "o semeador

\footnotetext{
10 S. B. Holanda, Raízes do Brasil, 1948, p.12.

${ }^{11}$ Idem, Raízes do Brasil, 2006, p.130-143.
} 
e o ladrilhador" iria discutir o "realismo chão", o deixar-se ir pela "rotina" que teria orientado a criação de vilas e cidades na América Portuguesa. Muito mais do que uma discussão pormenorizada da morfologia das cidades do Brasil colonial, Sérgio Buarque buscaria nessa relação precária com a urbanidade elementos para compor tal mentalidade.

Claro, a estrutura sequencial dos capítulos permanece. Mas esse novo capítulo $\mathrm{IV}$, individualizado - que se tornaria quase uma metonímia do próprio livro, na síntese fundamental dessa oposição entre ordem e desordem do empreendimento colonizador de espanhóis e portugueses, respectivamente -, deve ser compreendido a partir desse contexto original de construção do argumento de Sérgio Buarque.

Individualização que se expressa no título e é reforçado na composição da nota 4, "natureza e arte", que cita o sermão de sexagésima de Antonio Vieira, conformando a imagem do semeador que sintetizaria o "velho naturalismo português" e, em conseqüência, as raízes das relações do homem brasileiro com o seu espaço: "porque o semear he hua arte que tem mays de natureza que de arte; caya onde cahir", reverbera a passagem famosa. ${ }^{12}$

Mais ainda, como já observou o professor Edgar de Decca, a imagem da semeadura reverbera outras leituras, talvez mais fortes, das interpretações do Brasil:

(...) não me parece acertado afirmar que esta metáfora tenha sido sugerida, literariamente, pelo sermão do Padre Vieira. Há indícios de que ela funciona na obra de Sérgio como um modo ambiguamente indireto e elíptico para abordar o incômodo uso da metáfora da semeadura feito por Paulo Prado em sua polêmica obra Retrato do Brasil. Neste autor, a semeadura refere-se ao sêmen que por se espalhar em excesso dá forma a uma personalidade brasileira, que por transbordamento de sexualidade, torna-se, profundamente, melancólica. Espalhar o sêmen é, ao mesmo tempo, excesso de sexualidade e por decorrência histórica, povoamento. Assim é retratado o espírito de aventura dos portugueses na obra de Paulo Prado. ${ }^{13}$

Essa noção de semeadura, embora não usando essa palavra, seria central também na obra de Gilberto Freyre, em especial em Casa-Grande \& Senzala, para a formação da cultura tropical e mesmo para definir a chamada plasticidade do

\footnotetext{
12 S. B. Holanda, Raizes do Brasil, 1948, p.199.

${ }^{13}$ Edgar de Decca, Decifra-me ou te devoro: as metáforas em Raízes do Brasil, Rivista di Studi Portoghesi e Brasiliani, 2000, p.09.
} 
colonizador português. Contudo, em Raízes do Brasil, a metáfora da semeadura perderia o acento sexual. Ao se dessexualizar, "semeadura torna-se a forma de constituição da colônia e mais especificamente, de seu desdobramento do agrário para o urbano”. Distanciar-se-ia da alusão direta à atividade agrícola, tal qual em Vieira, para explicar a forma de criação das cidades, que, por sua vez, estaria relacionada, no fim, à formação do homem cordial. ${ }^{14}$

Assim, não deixa de ser significativo que, como relatou o professor Nestor Goulart, ${ }^{15}$ a polêmica e a argüição mais dura a sua tese de livre-docência não tenha vindo de Sérgio Buarque, mas de Paulo Santos - esse, sim, preocupado com as discussões sobre os padrões morfológicos dos núcleos urbanos coloniais construídos pelos portugueses e com as possibilidades de discutir os saberes formais que os orientavam para fundamentar uma obra que viria a lume alguns poucos anos depois. Sérgio Buarque teria se limitado às observações e correções pontuais, conferindo o rigor da pesquisa, do uso das fontes, checando datas, etc.

Há ainda outro aspecto a considerar. Canonizado pelo prefácio de Antonio Candido como um dos textos fundamentais que impactou a maneira da intelectualidade pensar o Brasil, Raízes do Brasil não foi um "clássico de nascença" todavia - embora tenha passado a ser assim lido. Não se pretende negar o lugar central do ensaio de Sérgio Buarque; ao contrário, tal afirmação apenas chama a atenção para o fato de que o livro circularia principalmente a partir dessa segunda edição. $^{16}$

Historicizar a composição do texto permite, assim, lembrar-nos que o texto de Sérgio se tornaria fundador não apenas pelo aporte teórico e conceitual rigoroso, mas por mobilizar uma série de temas e de fontes - em especial a dos viajantes, como o próprio Koster ou Le Gentil de la Barbinais, citados em mais de uma ocasião

\footnotetext{
${ }^{14}$ Ibidem, p.12.

15 Em entrevista, São Paulo, 02 jun. 2009; além de Sérgio Buarque e Paulo Santos, os professores Aroldo de Azevedo, Dirceu Lino de Mattos e Eurípedes Simões de Paula compuseram a banca examinadora da tese de Livre-Docência do professor Nestor.

16 Fábio Franzini, A coleção Documentos Brasileiros e as transformações da historiografia nacional (1936-1959), 2006, pp.11-13.
} 
por Robert Smith para ilustrar as imagens de desordem da Salvador colonial ${ }^{17}$ - que circulavam no ambiente cultural havia muito tempo.

É o relato de La Barbinais, proveniente de Nouvean voyage au tour du monde, de 1729, que serviria para Sérgio Buarque ilustrar uma das passagens fundamentais para consolidar a imagem de desordem da cidade luso-brasileira:

A fantasia com que em nossas cidades, comparadas às da América espanhola, se dispunham muitas vezes as ruas ou habitações é, sem dúvida, um reflexo de tais circunstâncias [a "aversão congênita a qualquer ordenação impessoal", relatada no parágrafo anterior]. Na própria Bahia, o maior centro urbano da colônia, um viajante do princípio do século XVIII notava que as casas se achavam dispostas segundo o capricho dos moradores. Tudo ali era irregular, de modo que a praça principal, onde se erguia o Palácio dos Vice-Reis, parecia estar só por acaso no seu lugar. ${ }^{18}$

17 Como, e.g., em R. C. Smith, The Colonial Architecture of Minas Gerais in Brazil, The Art Bulletin, 1939, p.142.

18 S. B. Holanda, Raízes do Brasil, 2006, p.114; fora as atualizações ortográficas, o texto é o mesmo de 1948 (p.155); salvo engano deste pesquisador ao comparar as duas primeiras edições, essa passagem não fazia parte do texto original de 1936. 
REFERÊNCIAS 
ABREU, Capistrano de. Capítulos de História Colonial. 1500-1800. 7 ed. rev. anot. Belo Horizonte: Itatiaia; São Paulo: Publifolha, 2000. [ed. orig. 1907]

ABREU, Mauricio de. O estudo geográfico da cidade no Brasil. In CARLOS, Ana Fani A. (org.). Os caminhos da reflexão sobre a cidade e o urbano. São Paulo: EDUSP, 1994, p.199-322.

AGACHE, A. Cidade do Rio de Janeiro: extensão - remodelação - embelezamento. Paris: Foyer Brésilien, [1930].

AGUIAR, Flavio. A moldura e o espelho. In E. de Decca e R. Lemaire (orgs.) Pelas Margens: outros caminhos da história e da literatura. Campinas: Editora da Unicamp, 2000. 27 p. [disponível em: http://www.unicamp.br/siarq/sbh/A_Moldura_e_o_Espelho.pdf acessado em 20 de junho de 2008]

ALEXANDRE, Marcus. Representação social: uma genealogia do conceito. Comum, Rio de Janeiro, v.10, n.23, jul.-dez. 2004, p.122-138.

ALMANDOZ, Arturo. Urban planning and historiography in Latin America. Planning in Progress, n.65, 2006, pp.81-123.

ALMEIDA, Maria Cecília F. de. Espaços públicos em João Pessoa (1889-1940): formas, usos e nomes. Dissertação, 2006 (Mestrado em Arquitetura e Urbanismo) - São Carlos, EESC-USP, 2006.

ALMEIDA, Marta de. Tempo de laboratórios, mosquitos e seres invisíveis: as experiências sobre a febre amarela em São Paulo. In Chalhoub, S. et al. Artes e ofícios de curar no Brasil: capítulos de história social. Campinas: Ed. Unicamp, 2003a, pp.123-160.

Perspectivas sanitárias e representações médicas nos congressos médicos latino-americanos (1901-1913). Horizontes, Bragança Paulista, v.21, jan.-dez. 2003b, pp.3747.

ANDRADE, Carlos R. M. Barry Parker: um arquiteto inglês na cidade de São Paulo. Tese, 1998 (Doutorado em Arquitetura e Urbanismo) - São Paulo, FAUUSP, 1998.

Camillo Sitte, Camille Martin e Saturnino de Brito: traduções e transferências de idéias urbanísticas. In RIBEIRO, L. C. Q. e PECHMAN, R. Cidade, povo e nação. Gênese do urbanismo moderno. Rio de Janeiro: Civilização Brasileira, 1996, p.287-310.

A peste e o plano: o urbanismo sanitarista do Eng. Saturnino de Brito. 2 vols. Dissertação, 1992 (Mestrado em Arquitetura e Urbanismo) - São Paulo, FAUUSP, 1992.

ANDRADE, Mário de. O Turista Aprendiz. São Paulo: Duas Cidades, 1976.

ANDRADE E SILVA, José Bonifácio de. Projetos para o Brasil. Organizado por Miriam Dolhnikoff. São Paulo: Companhia das Letras, Publifolha, 2000.

ANDREATTA, Verena. Cidades quadradas, paraísos circulares: os planos urbanísticos para o Rio de Janeiro no século XIX. Rio de Janeiro: Mauad X, 2006.

ANDRIOLO, Arley. Ouro Preto, 1897-1973: a construção social de uma cidade histórica turística. Dissertação, 1999 (Mestrado em Arquitetura e Urbanismo) - São Paulo, FAUUSP, 1999. 
ARANTES, Otília B. F. Urbanismo em fim de linha e outros estudos sobre o colapso da modernização arquitetônica. São Paulo: Edusp, 1998.

ARAÚJO, Francisco L. de O. Considerações geraes sobre a topografia phisico-medica da cidade do Rio de Janeiro. Rio de Janeiro: Typ. Guanabarense, 1852

ARAÚJO, Ricardo B. Guerra e Paz: Casa-Grande \& Senzala e a obra de Gilberto Freyre nos anos 30. 2 ed. São Paulo: ed. 34, 2005. [1 ${ }^{\mathrm{a}}$ ed. 1994]

ARRAIS, Raimundo. O Pântano e o Riacho: a formação do espaço público no Recife do século XIX. São Paulo: Humanitas/FFLCH/USP, 2004.

ASSUNÇÃO, Paulo de. A terra dos Brasis: a natureza da América Portuguesa vista pelos primeiros jesuítas (1549-1596). São Paulo: Annablume, 2000.

ATAS do CONGRESSO INTERNACIONAL Extraordinário de Críticos de Arte. Cidade Nova - a síntese das artes. Brasília, São Paulo e Rio de Janeiro, s.n., s.l., 17 a 25 set. 1959.

ATLAS do Império do Brazil: os mapas de Cândido Mendes - 1868. edição e textos: Ney O. R. Carvalho. Rio de Janeiro: Arte \& História, 2000.

AZEVEDO, Aroldo de. Vilas e cidades no Brasil colonial. Ensaio de geografia urbana retrospectiva. Boletim n.208 da FFLC da USP, Geografia, São Paulo, n.11, 1956.

São Paulo, da Vila Quinhentista à Metrópole Regional. Boletim Paulista da Geografia, n.39, p.12-46, 1961.

AZEVEDO, Fernando de. Cultura brasileira. 4 ed. São Paulo: Melhoramentos, 1964. [orig. 1946]

BACZKO, Bronislaw. Los imaginarios sociales: memorias y esperanzas colectivas. Buenos Aires: Nueva Visión, 1991 [ed. orig. 1984].

BAETA, Rodrigo E. Ouro Preto: Cidade barroca. Dissertação, 2003 (Mestrado em Arquitetura e Urbanismo) - Salvador, UFBA, Programa de Pós-Graduação em Arquitetura e Urbanismo, 2003.

BANDEIRA, Manuel. Guia de Ouro Preto. Rio de Janeiro: MES, 1938.

BARATA, Mário. Introdução. In PLANITZ, Karl R. Cidade de São Sebastião do Rio de Janeiro: oito sépias inéditas. Rio de Janeiro: Companhia Brasileira de Projetos e Obras, Livraria Kosmos, 1985.

Apresentação. In SCHEIER, Peter. Imagens do passado de Minas Gerais. Rio de Janeiro: Livraria Kosmos, [1986].

BARBOSA, Francisco de A. (org.). Raízes de Sérgio Buarque de Holanda. Rio de Janeiro: Rocco, 1988.

BARREIRO, José C. Imaginário e viajantes no Brasil do século XIX: cultura e cotidiano, tradição e resistência. São Paulo: Ed. UNESP, 2002.

BARRETO, Abílio. Belo Horizonte: memória histórica e descritiva - história antiga e história média. 2 ed. atual. rev. e anot. 2 vols. il. Belo Horizonte: Fundação João Pinheiro, Centro de Estudos Históricos e Culturais, 1996. [ed. orig. 1928 e 1936]

BAZIN, Germain. A Arquitetura religiosa barroca no Brasil. 2 vols. trad. Glória L. Nunes. Rio de Janeiro: Record, 1956. (revisão técnica e atualização a cargo de Mario Barata).

BEGUIN, François. As maquinarias inglesas do conforto. Espaço e Debates, São Paulo, n.34, p.39-54, 1991. [orig. 1977]

BELLUZZO, Ana Maria de M. O Brasil dos viajantes. 2 ed. 3 vols. São Paulo: Metalivros; Rio de Janeiro: Objetiva, 1999. 
BENCHIMOL, Jayme L. Pereira Passos: um Haussmann tropical: a renovação urbana da cidade do Rio de Janeiro no início do século XX. Rio de Janeiro: Secret. Mun. de Cultura, Turismo e Esportes, Depto. Geral de Documentação e Informação Cultural, Divisão de Editoração, 1992.

BENJAMIN, Walter. Magia e Técnica, arte e política: ensaios sobre literatura e história da cultura. trad. S. P. Rouanet. 7 ed. São Paulo: Brasiliense, 1994, p.222-232 (obras escolhidas, v.1).

BERNARDINI, Sidney P. Construindo infra-estruturas, planejando territórios: a Secretaria da Agricultura, Comércio e Obras Públicas do Governo Estadual Paulista (18921926). Tese. 2008 (Doutorado em Arquitetura e Urbanismo) - São Paulo, FAUUSP, 2008.

Um engenheiro norte-americano em Santos: os planos de Estevan A. Fuertes e de Saturnino de Brito no ideário urbanístico do final do século XIX. In VI Seminário de História da Cidade e do Urbanismo, Natal, out. 2000, Anais eletrônicos do VI SHCU cinco séculos de cidade no Brasil, PPGAU, UFRN, Natal, arquivo 110com2 [cd-rom], 2000.

BERTUCCI, Liane M. Remédios, charlatanices... e curandeiros: práticas de cura no período da gripe espanhola em São Paulo. In Chalhoub, S. et al. Artes e ofícios de curar no Brasil: capítulos de história social. Campinas: Ed. Unicamp, 2003, pp.197-227.

BICALHO, Maria F. A cidade e o Império: O rio de Janeiro no século XVIII. Rio de Janeiro: Civilização Brasileira, 2003.

BITTENCOURT, Luiz Cláudio. Regularidades do Visível. Tese. 1999 (Doutorado em Arquitetura e Urbanismo) - São Paulo, FAUUSP, 1999.

BOMFIM, Manoel. O Brasil na América: caracterização da formação brasileira. 2 ed. Rio de Janeiro: Topbooks, 1997. [ed. orig. 1929]

orig. 1905]

A América Latina: males de origem. Rio de Janeiro: Topbooks, 2005. [ed.

BOURDIER, Pierre. O poder simbólico. Rio de Janeiro: Bertrand Brasil, 1989.

BRESCIANI, Maria Stella M. O charme da ciência e a sedução da objetividade: Oliveira Vianna entre intérpretes do Brasil. São Paulo: Ed. UNESP, 2005.

A cidade: objeto de estudo e experiência vivenciada. In Encontro Nacional da ANPUR, 11, Salvador, maio 2005, Anais eletrônicos do $\mathbf{1 1}^{\mathbf{0}}$ ENANPUR, Salvador: PPGAU/UFBA, 2005. [cd-rom]

(org.) Palavras da cidade. Porto Alegre: Ed. Universidade/UFRGS, 2001.

Identidades inconclusas no Brasil do século XX - fundamentos de um lugarcomum. In BRESCIANI, M.S.M. e NAXARA, M. Memória e (res)sentimento: indagações sobre uma questão sensível. Campinas: Editora da Unicamp, p.403-429, 2001.

História e historiografia das cidades, um percurso. In M. C. FREITAS (org.). Historiografia brasileira em perspectiva. São Paulo: Contexto, Universidade São Francisco, 1998, pp.237-258.

. (org.). Imagens da Cidade: séculos XIX e XX. São Paulo: Marco Zero, ANPUH, FAPESP, 1994.

Brasiliense, 1982.

Londres e Paris no século XIX: o espetáculo da pobreza. São Paulo:

BRITO, Francisco Saturnino R. de. Obras Completas de Saturnino de Brito. 23 vols. Rio de Janeiro: Imprensa Nacional, 1943-1944. 
Os melhoramentos do Rio de Janeiro [1927]. In BRITO, Francisco Saturnino R. de. Obras Completas de Saturnino de Brito. v. 20. Rio de Janeiro: Imprensa Nacional, 1944, pp.179-184.

Le trace sanitaire des villes: technique sanitaire urbaine. [1916]. In BRITO, Francisco Saturnino R. de. Obras Completas de Saturnino de Brito. v. 20. Rio de Janeiro: Imprensa Nacional, 1944, pp.23-157.

Saneamento de Juiz de Fora, estudos preliminares [1915]. In BRITO, Francisco Saturnino R. de. Obras Completas de Saturnino de Brito. v. 5. Rio de Janeiro: Imprensa Nacional, 1943, pp.447-510.

Saneamento de Paraíba do Norte (João Pessoa) [1913]. In BRITO, Francisco Saturnino R. de. Obras Completas de Saturnino de Brito. v. 5. Rio de Janeiro: Imprensa Nacional, 1943, pp.285-428.

Saneamento de Recife: descrição e relatórios. $1^{\circ}$ tomo. In BRITO, Francisco Saturnino R. de. Obras Completas de Saturnino de Brito. v. 8. Rio de Janeiro: Imprensa Nacional, 1943.

Saneamento de Santos [1905-1909]. In BRITO, Francisco Saturnino R. de. Obras Completas de Saturnino de Brito. v. 7. Rio de Janeiro: Imprensa Nacional, 1943.

Saneamento de Campos [1903]. In BRITO, Francisco Saturnino R. de. Obras Completas de Saturnino de Brito. v. 6. Rio de Janeiro: Imprensa Nacional, 1943.

Saneamento de Campinas, Estado de S. Paulo [1897]. In BRITO, Francisco Saturnino R. de. Obras Completas de Saturnino de Brito. v. 5. Rio de Janeiro: Imprensa Nacional, 1943, pp.151-160.

Melhoramentos de Vitória, Espírito Santo [1896]. In BRITO, Francisco Saturnino R. de. Obras Completas de Saturnino de Brito. v. 5. Rio de Janeiro: Imprensa Nacional, 1943, pp.09-147.

BRITO FILHO, Francisco S. R. de. A higiotécnica e o urbanismo. Rio de Janeiro: Americana. Tese apresentada ao Primeiro Congresso Brasileiro de Urbanismo [xerografado], 1941.

BROCKEY, Liam M. (ed.) Portuguese colonial cities in the early modern world. Farnham: Ashgate, 2008 (serie: Empires and the making of the modern world, 1650-2000).

BRUAND, Yves. Lucio Costa: o homem e a obra. In NOBRE, Ana Luiz et al. (orgs.). Um modo de ser moderno: Lúcio Costa e a crítica contemporânea. São Paulo: Cosac \& Naify, 2004, p.13-17. [orig. 1981].

Arquitetura contemporânea no Brasil. 3 ed. São Paulo: Perspectiva, 1997

BUENO, Beatriz Piccolotto S. Desenho e Desígnio: o Brasil dos engenheiros militares (1500-1822). Tese. 2 vol. 2001 (Doutorado em Arquitetura e Urbanismo) - São Paulo, FAUUSP, 2001.

BUENO, Eduardo (org.). Os nascimentos de São Paulo. Rio de Janeiro: Ediouro, 2004.

BURKE, Peter. Variedades de História Cultural. Rio de Janeiro: Civilização Brasileira, 2000.

Abertura: a nova história, seu passado e seu futuro. In A Escrita da História: novas perspectivas. trad. M. Lopes. São Paulo: Ed. UNESP, 1992, p. 07-37.

A Escola dos Annales (1929-1989): a revolução francesa da historiografia. trad. Nilo Odalia. São Paulo: Fundação Editora da UNESP, 1990. 
BURTON, Richard, Sir. Viagem do Rio de Janeiro a Morro Velho. Apresentação e notas de M. Guimarães Ferri. trad. David Jardim Jr. São Paulo: Itatiaia, Edusp, 1976.

BURY, John. Arquitetura e Arte no Brasil colonial. Organizador Myriam A. R. de Oliveira. Brasília: IPHAN/Monumenta, 2006.

CALABI, Donatella. Storia dell'urbanistica europea. Torino: Paravia Scriptorium, 2000.

CALLOW JR., Alexander B. (ed.). American urban history: an interpretative reader with commentaries. $3^{\text {rd }}$ ed. New York: Oxford University Press, 1982 [ed. orig. 1969].

CAMARGO, Ana M. de A. e MORAES, Rubens B. Bibliografia da Impressão Régia do Rio de Janeiro. São Paulo: Edusp, Livraria Kosmos Editora, 1993.

CAMPOS, Candido M. Os Rumos da Cidade: urbanismo e modernização em São Paulo. São Paulo: Senac, 2002.

CAMPOS, Cristina de. Ferrovias e saneamento em São Paulo: o engenheiro Antonio Francisco de Paula Souza e a construção da rede de infra-estrutura territorial e urbana paulista, 1870-1893. Tese. 2007 (Doutorado em Arquitetura e Urbanismo) - São Paulo, FAUUSP, 2007.

A transformação da cidade pela educação sanitária: a atuação do sanitarista Geraldo Horácio de Paula Souza em São Paulo, 1922-1927. In VI Seminário de História da Cidade e do Urbanismo, Natal, out. 2000, Anais eletrônicos do VI SHCU - cinco séculos de cidade no Brasil, PPGAU, UFRN, Natal, arquivo 011 com2 [cd-rom], 2000.

CANDIDO, Antonio (org.). O significado de Raízes do Brasil [1965]. In Holanda, S. B. de. Raízes do Brasil. ed. rev. São Paulo: Companhia das Letras, 2006, pp.235-250. (edição comemorativa 70 anos, organizada por Ricardo B. de Araújo e Lilia M. Schwartz) Abramo, 1998.

Sérgio Buarque de Holanda e o Brasil. São Paulo: Editora Fundação Perseu

A visão política de Sérgio Buarque de Holanda. In Sérgio Buarque de Holanda e o Brasil. São Paulo: Editora Fundação Perseu Abramo, 1998, pp.11-28.

CANDIDO, Francisco de Paula. Relatório acerca da Saúde Publica. Rio de Janeiro: Typographia Nacional, 1856.

CAPEL Saez, Horacio. La Morfología de las ciudades: sociedade, cultura y paisaje urbano. Barcelona: Ediciones del Serbal, 2002.

CARDOSO, Adauto Lúcio. O urbanismo moderno e a questão da natureza. Tese. 1997. (Doutorado em Arquitetura e Urbanismo) - São Paulo, FAUUSP, 1997.

CARDOSO, Ciro F. e MALERBA, Jurandir (Orgs.) Representações. Contribuições para um debate transdisciplinar. Campinas: Papirus, 2000.

CARDOSO, Ciro F. Introdução: uma opinião sobre as representações sociais. In CARDOSO, C. F. e MALERBA, J. (Orgs.) Representações. Contribuições para um debate transdisciplinar. Campinas: Papirus, 2000, p.09-39.

CARVALHO, Jarbas S. de. Geografia médica do município de Ponta Nova (estado de Minas Gerais), relatório apresentado ao $10^{\circ}$ Congresso brasileiro de medicina (sucinta contribuição). Rio de Janeiro: Est. Graph. Canton \& Reile, 1932.

CARVALHO, José M. de, A formação das almas: o imaginário da república no Brasil. São Paulo: Companhia das Letras, 1990.

1981.

A construção da Ordem: a elite política imperial. Brasília: Universidade de Brasília, 
CARVALHO, Marta M. C. de.; HANSEN, João A. Modelos culturais e representação: uma leitura de Roger Chartier. Varia História, Belo Horizonte, n.16, set. 1996, p.07-24.

CASCUDO, Luis da Câmara. Vaqueiros e cantadores: folclore poético do Ceará, Paraíba, Rio Grande do Norte e Pernambuco. Rio de Janeiro: Ediouro, 2000 [ed. orig. 1939]

Prefácio do tradutor in Koster, H. Viagens ao Nordeste do Brasil. trad. e notas L. da Câmara Cascudo. São Paulo: Companhia Editora Nacional, p.09-28, 1942.

História da Cidade do Natal. 3 ed. Natal: IHGRN, 1999. [ed.orig.1947]

Rede de dormir: uma pesquisa etnográfica. Rio de Janeiro: Ministério da Educação e Cultura, Serviço de Documentação, 1959.

CAVALCANTI, Lauro. Moderno e Brasileiro: a história de uma nova linguagem na arquitetura (1930-60). Rio de Janeiro: Jorge Zahar, 2006.

CENTURIÃO, Luiz R. M. A cidade colonial no Brasil. Porto Alegre: EDPUCRS, 1999.

CERASOLI, Josianne F. A Grande Cruzada: os Engenheiros e as Engenharias de Poder na Primeira República. A fundação da Escola Politécnica de São Paulo. Dissertação (Mestrado em História) - Unicamp, IFCH, Campinas, 1998.

CHALHOUB, Sidney. Cidade febril: cortiços e epidemias na corte imperial. São Paulo: Companhia das Letras, 1996.

Machado de Assis: historiador. São Paulo: Companhia das Letras, 2003.

CHARTIER, Roger. O mundo como representação. Estudos Avançados, Rio de Janeiro, 11(5), 1991, p.173-191.

A história cultural: entre práticas e representações. Lisboa: Difel; Rio de Janeiro: Bertrand Brasil, 1988.

Histoire intellectuelle et histoire des mentalités. Trajectoires et questions. Revue de Synthése, IIIe Se., n.111-112, juil.-dec. 1983, p.277-307.

CHAUÍ, Marilena. O que é ideologia. 12 ed. São Paulo: Brasiliense, 1983.

CHOAY, Françoise. A regra e o modelo: sobre a teoria da arquitetura e do urbanismo. São Paulo: Perspectiva, 1985. [orig. 1980].

O Urbanismo: utopias e realidades. uma antologia. 5 ed. São Paulo: Perspectiva, 1998. [ed. orig. 1965]

CICCO, Januário. Como se higienizaria Natal: algumas considerações sobre o seu saneamento. Natal: Atelier Typ. M. Victorino, 1920.

COLLINS, George R. e COLLINS, Christiane C. (1965). Camillo Sitte y el nacimiento del urbanismo moderno. In SITTE, C. Construcción de ciudades segun principios artisticos. Barcelona: Gustavo Gili, 1980.

COMISSÃO DE SANEAMENTO DE NATAL. Relatório de Abril de 1924 (assinado pelo eng. Henrique de Novaes), Natal, s.n., 1924. [datilografado]

CONTINENTINO, Lincoln. Saneamento e urbanismo. Belo Horizonte: s.n., 1937.

COOPER, Donald. The new 'black death': cholera in Brazil, 1855-1856, In Kiple, Kenneth (ed.), The African exchange: toward a biological history of black people. Durham e Londres: Duke University Press, 1987, p.235-256.

CORREIA, Telma de B. A construção do Habitat Moderno no Brasil - 1870-1950. São Carlos: RiMa, 2004. 
COSTA, Ana de Lourdes R. da. Salvador, século XVIII: o papel da ordem religiosa dos Beneditinos no processo de crescimento urbano. Tese. 2003 (Doutorado em Arquitetura e Urbanismo), Barcelona, Universitat Politècnica de Barcelona, ETSAB, 2003.

COSTA, Franciso X. La ordenación de los flujos indeseables. Gestión residual y organización socioespacial de la ciudad contemporánea. Paris (1855), Barcelona (1891-1902) y Salvador (1926). In VII Seminário de História da Cidade e do Urbanismo, Salvador, out. 2002, Anais eletrônicos - Historiografia da cidade e do urbanismo: balanço da produção recente e desafios atuais, PPGAU, FAUFBA, ANPUR, Salvador, arquivo 8_018.htm [cd-rom], 2002.

COSTA, Lúcio. Documentação necessária. Revista do Serviço do Patrimônio Histórico e Artístico Nacional Rio de Janeiro, Ministério da Educação e Saúde, pp.31-39, 1937.

Razões da nova Arquitetura. In XAVIER, Alberto (org.). Depoimento de uma geração: arquitetura moderna brasileira. ed. rev. ampl. São Paulo: Cosac \& Naify, pp. 39-52, 2003 [texto original de 1936].

A situação do ensino das Belas-Artes. In XAVIER, Alberto (org.). Depoimento de uma geração: arquitetura moderna brasileira. ed. rev. ampl. São Paulo: Cosac \& Naify, pp. 57-58, 2003 [texto original publicado em 29 dez 1930].

COSTA, Maria de F. e DIENER, Pablo. A América de Rugendas: obras e documentos. São Paulo: Estação Liberdade, Kosmos, 1999.

CUTMORE, Jonathan. The Quartely Review under Gifford: an overview. Quartely Review Archive. Disponível em: <http://www.rc.umd.edu/reference/qr/founding/intro.html> [acessado em 10/10/2007]

CYMBALISTA, Renato. Sangue, ossos e terras: os mortos e a ocupação do território lusobrasileiro, séculos XVI e XVII. Tese. 2006 (Doutorado em Estruturas urbanas ambientais) São Paulo, FAUUSP, 2006.

DALAND, Robert T. Brazilian Planning: development politics and administration. Chape Hill: The University of North California Press, 1967.

DAL CO, Francesco. De los parques a la región: ideología progresista y reforma de la ciudad americana, In Ciucci, G. et al. La Ciudad Americana: de la guerra civil al New Deal. Barcelona: Gustavo Gili, 1975, p.141-293.

D’ALLONES, Myriam Revault. Le dépérissement de la politique: généalogie d'un lieu commum. Paris: Flammarion, 1999.

DANTAS, George A. F. Linhas convulsas e tortuosas retificações: transformações urbanas em Natal nos anos 1920. Dissertação (Mestrado em Arquitetura e Urbanismo), São Carlos, EESC-USP, 2003.

DARNTON, Robert. O beijo de Lamourette: mídia, cultura e revolução. trad. Denise Bottmann. São Paulo: Companhia das Letras, 1995 [ed. orig. 1990]

DECKKER, Zilah Q. Brazil built: the architecture of the modern movement in Brazil. London: Spon Press, 2001

DE DECCA, Edgar S. Raízes do Brasil: um ensaio de formas históricas. 16 p. In E. de Decca e R. Lemaire (orgs.) Pelas Margens: outros caminhos da história e da literatura. Campinas: Editora da Unicamp, 2000. [disponível em: http://www.unicamp.br/siarq/sbh/Raizes_do_Brasil-um_ensaio_das_formas_historicas.pdf - acessado em 20 de junho de 2008]

Decifra-me ou te devoro: as metáforas em Raízes do Brasil. Rivista di Studi

Portoghesi e Brasiliani, Roma, vol. 2, 2000, 16 p. [disponível em: 
http://www.unicamp.br/siarq/sbh/Decca-Metaforas_em_Raizes_do_Brasil.pdf - acessado em 20 de junho de 2008].

DE SUZANNET, Conde. O Brasil em 1845 (semelhanças e diferenças após um século). trad. Márcia de Moura Castro. Rio de Janeiro: Casa do Estudante do Brasil, [1957].

DEL BRENNA, Giovana R. (org.) O Rio de Janeiro de "Pereira Passos": uma cidade em questão II. Rio de Janeiro: Index, 1985.

DEL BRENNA, Giovana R. Modelo alternativo ou variante? Reflexões sobre a 'regularidade relativa' de algumas cidades de fundação portuguesa. Seminário de História da Cidade e do Urbanismo, 4, Anais..., Rio de Janeiro: UFRJ/PROURB, vol. I, 1996.

Medieval ou Barroco? Proposta de leitura do espaço urbano colonial. Barroco, Belo Horizonte, n.12, p.141-145, 1982-1983.

DELSON, Roberta M. Novas vilas para o Brasil-Colônia: planejamento espacial e social no século XVIII. Brasilia: Alvi-Ciord, 1997. [ed. orig. 1979]

DEWALD, Jonathan. Roger Chartier and the fate of cultural history. French Historical Studies, vol. 21, n.02, spring 1998, p.221-240.

DIAS, Maria Odila L. da S. Política e sociedade na obra de Sérgio Buarque de Holanda. In Candido, A. (org.) Sérgio Buarque de Holanda e o Brasil. São Paulo: Editora Fundação Perseu Abramo, 1998, pp.11-28.

DIEHL, Astor A. A cultura historiográfica brasileira: do IHGB aos anos 1930. Ediupf, 1998.

DIFFIE, Bailey W. and WINIUS, George D. Foundations of the Portuguese Empire, 1415-1580. Minneapolis: University of Minnesota Press, 1977. (Europe and the World in the age of expansion, vol. I).

DIFFIE, Bailey W. Latin America civilization: colonial period. Harrisburg: Stackpole Sons, 1945.

DINIZ, Ariosvaldo da S. As artes de curar nos tempos do cólera: Recife, 1856, In Chalhoub, S. et al. Artes e ofícios de curar no Brasil: capítulos de história social. Campinas: Ed. Unicamp, 2003, pp.355-385

Cólera: representações de uma angústia coletiva (a doença e o imaginário social no século XIX no Brasil). Tese (Doutorado em História) - IFCH, Unicamp, Campinas, 1998.

D’ORBIGNY, Alcide. Viagem pitoresca através do Brasil. Belo Horizonte: Itatiaia, São Paulo: Edusp, 1976. [original Voyage dans les deus Amériques]

EDLER, Flávio C. A Escola Tropicalista Baiana: um mito de origem da medicina Tropical no Brasil. História, Ciências, Saúde - Manguinhos, Rio de Janeiro, vol. IX (2), p.357-85, maio-ago. 2002.

De olho no Brasil: a geografia médica e a viagem de Alphonse Rendu. História, Ciências, Saúde - Manguinhos, vol. VIII (suplemento), 2001, pp. 925-43.

ERMAKOFF, George. Rio de Janeiro 1840-1900: uma crônica fotográfica. Rio de Janeiro: G. Ermakoff Casa Editorial, 2006.

EVENSON, Norma. Two Brazilian capitals: architecture and urbanism in Rio de Janeiro and Brasília. New Haven and London: Yale University Press, 1973.

FELDMAN, Sarah. Planejamento e Zoneamento. São Paulo: 1947-1972. São Paulo: EDUSP, 2005. 
FERREIRA, Angela de A., DANTAS, George A. F. (Orgs.) Surge et Ambula: a construção de uma cidade moderna (Natal, 1890-1940). Natal: EDUFRN, 2006.

FERREIRA, Angela de A., DANTAS, George A. F. "Em nome da cidade": modernização, história e cultura urbana em Câmara Cascudo nos anos 1920. In: Eduardo Kingman Garcés (Org.). Historia Social Urbana: espacios y flujos. Quito: Flacso Ecuador, Ministerio de Cultura, 2009, pp. 155-172.

FERREIRA, Angela de A., DANTAS, George A. F. e FARIAS, Hélio T. M. Pensar e agir sobre o território das secas: planejamento e cultura técnica no Brasil (1870-1920). Vivência, Natal, UFRN, CCHLA, n. 34, 2008, pp. 41-62.

FERREIRA, Angela de A., EDUARDO, Anna Rachel B., DANTAS, George A. F. Saudáveis trópicos: cidade, higiene e ordem para a Nação em formação (Brasil, 1850-1930), in Eulalia Ribera Carbó, Héctor Mendonza Vargas, Pere Sunyer Martín (orgs). La integración del território en una idea de Estado. México y Brasil, 1821-1946. Ciudad de México: UNAM, Instituto de Geografia, Instituto de Investigaciones Dr. José Maria Luis Mora, 2007, pp.439-469.

FERREIRA, Angela de A., EDUARDO, Anna Rachel B., DANTAS, Ana Caroline de C. L. Geografias e Topografias médicas: os primeiros estudos ambientais da cidade concreta. Investigaciones Geográficas. Universidad Nacional Autônoma de México. México, v.52, 2004, p.83-98.

FERREIRA, Angela de A., EDUARDO, Anna Rachel B., DIAS, Ana Caroline de C. D. e DANTAS, George A. F. Uma cidade sã e bela: a trajetória do saneamento de Natal. 18501969. Natal: CREA-RN, IAB-RN, 2008.

FERREIRA, Flávia. Cidades coloniais brasileiras e espanholas na América: uma abordagem comparativa. Seminário de História da Cidade e do Urbanismo, 4, Anais..., Rio de Janeiro: UFRJ/PROURB, vol. I, 1996.

FERREIRA, Luis Otávio. Medicina impopular: ciência médica e medicina popular nas páginas dos periódicos científicos (1830-1840). In Chalhoub, S. et al. Artes e ofícios de curar no Brasil: capítulos de história social. Campinas: Ed. Unicamp, 2003, pp.101-122.

FERREZ, Gilberto. O Brasil do Primeiro Reinado visto pelo botânico William John Burchell 1825/1829. Rio de Janeiro: Fundação João Moreira Salles, Fundação Nacional PróMemória, 1981

FICHER, Sylvia e ACAYABA, Marlene M. Arquitetura moderna brasileira. São Paulo: Projeto, 1982.

FLEXOR, Maria H. O. Os núcleos urbanos planejados do século XVIII: Porto Seguro e São Paulo. Salvador: UFBA, Centro de Estudos Baianos, 1989.

Núcleos urbanos criados por Pombal no Brasil do século XVIII. Seminário de História da Cidade e do Urbanismo, 4, Anais..., Rio de Janeiro: UFRJ/PROURB, vol. I, 1996.

FONSECA, Cláudia D. Mariana e o urbanismo português do século XVIII. Seminário de História da Cidade e do Urbanismo, 4, Anais..., Rio de Janeiro: UFRJ/PROURB, vol. I, 1996.

FRANÇA, Jean M. C. Visões do Rio de Janeiro colonial: antologia de textos (1531-1800). Rio de Janeiro: EDUERJ; J. Olympio, 1999.

FREYRE, Gilberto. Brasis, Brasil e Brasília. Rio de Janeiro: Gráfica Record, 1968.

Ingleses no Brasil: aspectos da influência britânica sobre a vida, a paisagem e a cultura do Brasil. 2 ed. Rio de Janeiro: José Olympio, Brasília: INL, 1977 [ed. orig. 1948] 
Introdução. In Arquitetura Civil I (textos escolhidos da Revista do IPHAN). São Paulo: FAUUSP, MEC/IPHAN, 1975, p. 03-26 [orig. 1943].

Sugestões para o estudo da arte brasileira em relação com a de Portugal e a das colônias. Revista do Serviço do Patrimônio Histórico e Artístico Nacional. Ministério da Educação e Saúde. Rio de Janeiro, n.1, 1937, pp.41-44.

Sobrados e Mucambos: decadência do patriarcado rural e desenvolvimento do urbano. 15 ed. São Paulo: Global, 2004. [ed. orig. 1936]

Casa-grande \& Senzala: formação da família brasileira sob o regime da economia patriarcal. 51 ed. rev. São Paulo: Global, 2006. [ed. orig. 1933]

FRIDMAN, Fania. Breve história do debate sobre a cidade colonial brasileira. In Pinheiro, E. P. e Gomes, M. A. A. de F. (orgs.) A cidade como História: os arquitetos e a historiografia da cidade e do urbanismo. Salvador: EDUFBA, 2004, p.43-72.

FUNDAÇÃO CALOUSTE GULBEKIAN. Robert C. Smith (1912-1975): a investigação na História da Arte. Lisboa: Fundação Calouste Gulbekian, [2000]

GARCİA MARTIN, Pedro. Maravillas y certezas: del espacio fantástico al espacio real en la Europa Moderna. In Vaca Lorenzo, Ángel. La formación del espacio histórico: transportes y comunicaciones. Salamanca: Ediciones Universidad de Salamanca, 2001, pp.191-213.

GARDINER, C. Harvey. Introduction. In Koster, H. Travels in Brazil. Carbondalle: Southern Illinois University Press, 1966, pp. vii-xvi. (Latin American Travel)

GARDINER, Patrick. Teorias da História. 5 ed. Lisboa: Fundação Calouste Gulbenkian, 2004 [ed. orig. 1959].

GINZBURG, Carlo. Representação. A palavra, a idéia, a coisa. In Olhos de madeira: nove reflexões sobre a distância. São Paulo: Companhia das Letras, 2001, p.85-103. [ed. orig. 1998].

Mitos, Emblemas e Sinais: morfologia e história. São Paulo: Companhia das Letras, 1990 [orig. 1986].

O queijo e os vermes: o cotidiano e as idéias de um moleiro perseguido pela Inquisição. 3 ed. São Paulo: Companhia das Letras, 2005. [ed. orig. 1976]

GIUCCI, Guillermo. Viajantes do maravilhoso: o Novo Mundo. trad. Josely V. Baptista. São Paulo: Companhia das Letras, 1992.

GODFREY, Brian J. Modernizing the Brazilian City. Geographical Review, vol.81, n.01, jan. 1991, p.18-34.

GODOY, Armando A. A Urbs e seus problemas. Rio de Janeiro: Jornal do Comercio, 1943.

GOMBRICH, E. H. Por uma história cultural. Lisboa: Gradiva, 1994 [ed. orig. 1969].

Arte e Ilusão: um estudo da psicologia da representação pictórica. São Paulo: Martins Fontes, 1986. [ed. orig. 1959]x

GOMES, Marco Aurélio A. de Filgueiras e LIMA, Fábio J. M. Pensamento e prática urbanística em Belo Horizonte, 1895-1961. in LEME, Maria C. da S. Urbanismo no Brasil. São Paulo: FUPAM, Studio Nobel, 1999, pp. 120-140.

GOMES, Plácido P. Considerações Patológicas Regionais (sobre o município de Joinville): Contribuição ao estudo social-nosográfico do país. Joinville: Boehm, 1926.

GOMIDE, Helou. Memória em Goiás: permanências e construções históricas com a transferência da capital do estado de Goiás na década de 1930. In VI Seminário de História 
da Cidade e do Urbanismo, Natal, out. 2000, Anais eletrônicos do VI SHCU - cinco séculos de cidade no Brasil, PPGAU, UFRN, Natal, 2000 [cd-rom].

GONZAGA, Antonio G. Climatologia e Nosologia do Ceará: páginas de medicina tropical. Rio de Janeiro: Baptista de Souza, 1925.

GOODWIN, Philip. Brazil Builds: Architecture old and new 1652-1942. New York: MoMA, 1943.

GORELIK, Adrian. Miradas sobre Buenos Aires: historia cultural y crítica urbana. Buenos Aires: Siglo XXI Editores Argentina, 2004.

La Grilla y el Parque: espacio público y cultura urbana en Buenos Aires, 1887-1936. Bernal: Universidad Nacional de Quilmes, 1998.

GRAHAM, Maria. Diário de uma viagem ao Brasil. trad. A. J. L. Belo Horizonte: Itatiaia; São Paulo: Editora da Universidade de São Paulo, 1990. [1st ed. 1824]

GUERRA, Abílio. Lúcio Costa - modernidade e tradição: montagem discursiva da arquitetura moderna brasileira. Tese. 2002 (Doutorado em História) - Campinas, Unicamp, IFCH, 2002.

GUIMARÃES, Berenice M. A concepção e o projeto de Belo Horizonte: a utopia de Aarão Reis. In RIBEIRO, Luiz C. de Q. e PECHMAN, Robert M. (orgs.) Cidade, Povo e Nação: gênese do urbanismo moderno. Rio de Janeiro: Civilização Brasileira, 1996, pp.123-140.

GUIMARAES, Lucia M. P. Henrique Fleiüss: vida e obra de um artista prussiano na Corte (1859-1882). Artcultura: Revista de História, Cultura e Arte, Uberlândia, v.8, n.12, 2006.

GUNN, Philip O. M. A ascensão dos engenheiros e seus diálogos e confrontos com os médicos no urbanismo sanitário em São Paulo. Seminário de História da Cidade e do Urbanismo, 7, Salvador, 2002. Anais eletrônicos do VII SHCH, Salvador, PPGAU-UFBA, 2002 (CD-ROM, arquivo 8_002.htm)

GUNN, Philip O. M., CORREIA, Telma de B. O Urbanismo: a medicina e a biologia nas palavras e imagens da cidade, In Bresciani, M. S. (Org.), Palavras da cidade. Porto Alegre: UFRGS, 2001, pp.227-260.

GUTIÉRREZ, Ramón. Arquitectura y Urbanismo em Iberoamérica. Madrid: Cátedra, 1983.

HARLEY, J. B. La nueva naturaleza de los mapas: ensayos sobre la historia de la cartografia. México: Fondo de Cultura Económica, 2005.

HARRIS, Marvin. Town and Country in Brazil: a social-anthropological study of a small Brazilian town. New York: The Norton Library, 1971 [orig. 1956].

HARVEY, David. Paris, capital of modernity. New York: Routledge, 2006.

HILL, Lawrence F. (ed.) Brazil. Berkeley and Los Angeles: University of California Press, 1947. (The United Nations series)

HOLANDA, Sérgio B. de. Raízes do Brasil. ed. rev. São Paulo: Companhia das Letras, 2006. (edição comemorativa 70 anos, organizada por Ricardo B. de Araújo e Lilia M. Schwartz) [ed. orig. 1936]

A revolução subterrânea [em entrevista]. Folha de São Paulo, São Paulo, Caderno Mais, pp.12-14, 08 ago. 2004. [1981]

Visões do paraíso: os motivos edênicos no descobrimento e colonização do Brasil. São Paulo: Brasiliense, Publifolha, 2000. [ed. orig. 1959]

Raízes do Brasil. 2 ed. rev. ampl. São Paulo: Livraria José Olympio, 1948. 
Raízes do Brasil. São Paulo: Livraria José Olympio Editora, 1936 (Coleção Documentos Brasileiros, n.1).

HOLANDA, Sérgio B. and GRAHAM, Richard. An Interview with Sérgio Buarque de Holanda. The Hispanic American Historical Review, vol. 62, n. 1, Feb. 1982, pp. 3-17.

HUNT, John Dixon. Gardens and the Picturesque: studies in the History of Landscape Architecture. Cambridge: The MIT Press, 1992.

ISABELLE, Arsène. Viaje a la Argentina, Uruguay y Brasil. 1830-1834. Buenos Aires: Emecé, 2001. [ed. orig. 1835]

ISENBURG, Teresa (Org.). Naturalistas italianos no Brasil. São Paulo: Ícone; Secretaria de Estado da Cultura, 1990.

KESSEL, Carlos. Tesouros do Morro do Castelo: mistério e história nos subterrâneos do Rio de Janeiro. Rio de Janeiro: Jorge Zahar, 2008.

Entre o pastiche e a modernidade: arquitetura neocolonial no Brasil. Tese, 2002 (doutorado em História Social) - Rio de Janeiro, UFRJ, PPGHIS, 2002.

KOSMINSKY, Ethel V., LÈPINE, Claude, PEIXOTO, Fernanda A. (orgs.). Gilberto Freyre em quatro tempos. Bauru: Edusc, 2003.

KOSTER, Henry. Viagens ao Nordeste do Brasil. trad. e notas L. C. Cascudo. São Paulo: Companhia Editora Nacional, 1942. [ed. orig. 1816]

Travels in Brazil. London: Longman, Hurst, Rees, Orme, and Brown, 1816.

KUBLER, George e SORIA, Martin. Art and Architecture in Spain and Portugal and their American dominions. 1500 to 1800. Baltimore: Penguin Books, [1959].

LAGO, Pedro Correa do. Coleção Princesa Isabel: fotografia do século XIX. Rio de Janeiro: Capivara, 2008.

LAHUERTA, Flora M. "Viajantes e a construção de uma idéia de Brasil no ocaso da colonização (1808-1822)". Scripta Nova: Revista Electrónica de Geografia y Ciencias Sociales, Universidad de Barcelona, vol. X, n. 218 (64), 01 ago. 2006, 19 p. <http://www.ub.es/geocrit/sn/sn-218-64.htm> [ISSN: 1138-9788]

LAMBERT, Jacques. Os dois Brasis. 2 ed. São Paulo: Companhia Editora Nacional, 1967. (Brasiliana, vol. 335)

LAMOUNIER, Bolívar. Sérgio Buarque e os 'grilhões do passado'. In Holanda, S. B. de. Raízes do Brasil. ed. rev. São Paulo: Companhia das Letras, 2006, pp.275-293. (edição comemorativa 70 anos, organizada por Ricardo B. de Araújo e Lilia M. Schwartz)

LAPA, José R. do A. Cidade: os cantos e os antros: Campinas 1850-1900. São Paulo: Edusp, 1996.

LEENHARDT, Jacques. Raízes do Brasil de Sérgio Buarque de Holanda: algumas questões sobre a origem da colonização portuguesa no Brasil. s/d. 14 p. [disponível em: http://www.unicamp.br/siarq/sbh/Raizes_do_Brasil_Jacques.pdf - acessado em 20 de junho de 2008]

LE GOFF, Jacques. As mentalidades: uma história ambígua. In Le Goff, Jacques e Nora, Pierre. História: novos objetos. 3 ed. Rio de Janeiro: F. Alves, 1988, p.68-83 [ed. orig. 1974].

LEITE, José Roberto T. Viajantes do imaginário: a América vista da Europa. Revista USP, n. 30 [dossiê Brasil dos viajantes], São Paulo, CCS, USP, jun./jul./ago. 1996, p.34-45.

LEME, Maria Cristina da S. Urbanismo no Brasil - 1895-1965. São Paulo: FUPAM, Studio Nobel, 1999. 
LEMOS, Carlos A. C. Arquitetura Brasileira. São Paulo: Melhoramentos, Editora da Universidade de São Paulo, 1979.

LEONÍDIO, Otavio. Carradas de razões: Lucio Costa e a arquitetura moderna brasileira. Rio de Janeiro: Ed. PUC-Rio; São Paulo: Loyola, 2007

LEPETIT, Bernard. Das capitais às praças centrais. Mobilidade e centralidade no pensamento econômico francês. In: Salgueiro, H. A. (org.) Cidades capitais do século XIX: racionalidade, cosmopolitismo e transferência de modelos, São Paulo: EDUSP, 2001, pp.41-63.

LIMA, Fábio J. M. de. As noções urbanísticas do engenheiro Francisco Baptista de Oliveira. In VI Seminário de História da Cidade e do Urbanismo, Natal, out. 2000, Anais eletrônicos - cinco séculos de cidade no Brasil, PPGAU, UFRN, Natal, arquivo 068mr2 [cd-rom], 2000.

LIMA, M. de Oliveira. Memórias (estas minhas reminiscências...). Rio de Janeiro: José Olympio Editora, 1937. (coleção Documentos Brasileiros, n.2).

Irmãos, 1920.

Na Argentina (impressões, 1918-19). São Paulo e Rio de Janeiro: Weiszflog

Relação dos manuscriptos portuguezes e estrangeiros, de interesse para o Brazil, existentes no Museu Britanico de Londres, Rio de Janeiro: Typ do Brazil, 1903 (edição do IHGB).

Pernambuco: seu desenvolvimento histórico. Leipzig: F. A. Brockhaus, 1895.

LIRA, José Tavares Correia de. Crítica modernista e urbanismo: Geraldo Ferraz em São Paulo, da Semana a Brasília. Encontro Nacional da ANPUR, 9, Salvador, 2005. Anais eletrônicos do IX ENANPUR, Salvador, 2005 (CD-ROM).

O Urbanismo e o seu outro: raça, cultura e cidade no Brasil (1920-1945). Revista Brasileira de Estudos Urbanos e Regionais, São Paulo, n.01, maio 1999, p.4778.

Mocambo e Cidade: regionalismo na arquitetura e ordenação do espaço habitado. Tese, 1996 (Doutorado em arquitetura e urbanismo) - São Paulo, FAUUSP, 1996.

O germe da lei urbana e a higiene da casa (e) do operário: primeiros delineamentos de uma política de segregação dos espaços do habitar em Pernambuco, entre 1889 e 1929. In IV Encontro Nacional da ANPUR, Salvador, 1991, Anais..., Salvador: PPGAU, UFBA, 1991.

LOCKHART, James and SCHWARTZ, Stuart B. Early Latin America: a history of colonial Spanish America and Brazil. Cambridge: Cambridge University Press, 1983. (Cambridge Latin American Studies, 46)

MACEDO, Joaquim Manuel de. Um passeio pela cidade do Rio de Janeiro. v. 1. São Paulo: Planeta do Brasil; Rio de Janeiro: Fundação Biblioteca Nacional, 2004. [ed. orig. 1862]

MACHADO, Roberto; LOUREIRO, Angela; LUZ, Rogério; MURICY, Kátia. Danação da norma: a Medicina Social e a constituição da Psiquiatria no Brasil. Rio de Janeiro, Graal, 1978.

MAGOSSI, Eduardo; LUQUET, Mara; PESSOA, Jalber. São Paulo relembrada: Militão, um novo álbum comparativo (1862-1887 e 2003). São Paulo: JSN Editora, 2003.

MAIA, Francisco Prestes. Estudo de um Plano de Avenidas para a cidade de São Paulo. São Paulo: Melhoramentos, 1930. 
MAKOWIECKY, Sandra. Representação: a palavra, a idéia, a coisa. Caderno de Pesquisa Interdisciplinar em Ciências Humanas, Florianópolis, n.57, dez. 2003, 25 pp.

MANLEY, Deborah. Two brides: the Baroness Menu von Minutoli and Mrs Colonel Elwood. In STARKEY, Paul and STARKEY, Janet (ed.). Travellers in Egypt. London, New York: Tauris Parke Paperback, 2001, pp.97-107.

MANNHEIM, Karl. Ideología y Utopía: introducción a la sociologia del conocimiento. Trad. S. Echavarría. Ciudad de México: Fondo de Cultura Econômica, 1987. [ed. orig. 1936]

MANTHORME, Katherine E. Tropical Renaissance: North American artists traveling in Latin America, 1839-1879. Washington: Smithsonian Institut Press, 1989.

MARINS, Paulo C. G. Através da rótula: sociedade e arquitetura urbana no Brasil, séculos XVII a XX. São Paulo: Humanitas/FFLCH/USP, 2001.

MARSON, Izabel de Andrade. O império da “conciliação": política e método em Joaquim Nabuco - a tessitura da revolução e da escravidão. Tese, 2000 (Livre-Docência em História). Campinas, Unicamp, 2000.

Feudalismo e escravidão: representações da sociedade pernambucana no

Travels in Brazil de Henry Koster. Clio. Revista de Pesquisa Histórica, n. 16, Recife, UFPE, 1996, pp. 83-109.

. Imagens da condição feminina em "Travels in Brasil" de Henry Koster.

Cadernos Pagu, n.4, Campinas, Unicamp, 1995, pp. 219-242.

MARTINS, Carlos A. F. "Hay algo de irracional...": apuntes sobre la historiografía de la arquitectura brasileña. Block, n.4, pp.08-22, dec. 1999.

Arquitetura moderna no Brasil: uma trama recorrente. In Arquitetura e Estado no Brasil: elementos para análise da constituição do discurso moderno no Brasil. A obra de Lucio Costa 1924-52. Dissertação (Mestrado em História) - Campinas, PUCCamp, 1988.

Lucio Costa e Le Corbusier: afinidades eletivas. In NOBRE, Ana Luiza et al. (orgs.) Um modo de ser moderno: Lúcio Costa e a crítica contemporânea. São Paulo: Cosac \& Naify, pp.71-83, 2004.

MARTINS, Luciana de Lima. O Rio de Janeiro dos viajantes: o olhar britânico (18001850). Rio de Janeiro: Jorge Zahar, 2001.

MARX, Karl. The German Ideology. s. 1., Progress Publishers, 1968 [escrito em 1845-46; publicado integralmente em 1932; disponível em Marx-Engels Internet Archive, http://www.marxists.org/archive/marx/works/1845-gi/index.htm]

História. In Ideologia Alemã. São Paulo: Hucitec, p.39-53, 1986.

MATTA, Alfredo da. Geografia e topografia médica de Manaus. Manaus: Typ. da Liv. Renaud, 1916.

MELLO, Joana. Ricardo Severo: da arqueologia portuguesa à arquitetura brasileira. São Paulo: Annablume, 2007.

MELLO, L. de Anhaia. Problemas de urbanismo: bases para a resolução do problema téchnico. 1929.

MINDLIN, Henrique. Arquitetura moderna no Brasil. Rio de Janeiro: Aeroplano, IPHAN, 2000. (ed.orig. 1956).

MONTEIRO, Charles. Porto Alegre e suas escritas: histórias e memórias da cidade, EDIPUCRS, 2006.

MONTEIRO, Pedro Meira. Sérgio Buarque de Holanda e as palavras. In Seminário Arquivo \& Pesquisa - caminhos sem fronteiras: o arquivo de Sérgio Buarque de 
Holanda, Campinas, Siarq, Unicamp, maio 1997, 12 p. [disponível em: http://www.unicamp.br/siarq/sbh/Pedro_Meira_Monteiro.pdf - acessado em 20 de junho de 2008]

MOREIRA, Fernando D. A formação do urbanismo moderno no Brasil: as concepções urbanísticas do engenheiro Saturnino de Brito. Espaço e Debates, São Paulo, n.40, 1997, p.55-69.

A construção de uma cidade moderna: Recife (1909-1926). Dissertação. 1994 (Mestrado em Desenvolvimento Urbano) - Recife, UFPE, 1994.

MORSE, Richard M. Balancing Myth and Evidence: Freyre and Sérgio Buarque. LusoBrazilian Review, vol. 32, n. 2, Culture and Ideology in the Americas: essays in Honor of Richard M. Morse, Winter 1995, pp. 47-57.

The city-idea in Argentina: a study in evanescence. Revista de História, São Paulo, vol. LII, n.104, 1975, pp.783-802.

Some characteristics of Latin America Urban History. The American Historical Review, vol.67, n.02, jan. 1962, p.317-338.

MURARI, Luciana. Tudo o mais é paisagem: representações da natureza na cultura brasileira. Tese. 2002 (Doutorado em História Social). São Paulo, FFLCH-USP, 2002.

MUSSET, Alain. O deslocamento das cidades, uma tradição hispano-americana? O caso de Parangaricutiro (Mexico, 1944). Imaginários, USP, vol. 13, n.14, 2007, pp.139-166.

NATAL, Caion Meneguello. Ouro Preto: a construção de uma cidade histórica, 1891-1913. Dissertação, 2007 (Mestrado em História) - Campinas, Unicamp, IFCH, 2007.

NAXARA, Márcia R. C. Estrangeiro em sua própria terra: representações do brasileiro, 1870-1920. São Paulo: Annablume, 1998.

NEVES, Cylaine M. das. A vila de São Paulo de Piratininga. Fundação e representação. São Paulo: Annablume, Fapesp, 2007.

NEVES, Lourenço B. "Introdução". In BRASIL. Ministério de Educação e Saúde. Instituto Nacional do Livro. Obras Completas de Saturnino de Brito. Vol. I (publicações preliminares). Rio de Janeiro: Imprensa Oficial, 1943, pp. ix-xviii.

NOBRE, Ana Luiza et al. (orgs.) Um modo de ser moderno: Lúcio Costa e a crítica contemporânea. São Paulo: Cosac \& Naify, 2004.

NONATO, José A. e SANTOS, Nubia M. (orgs.). Era uma vez o Morro do Castelo. 2 ed. Rio de Janeiro: IPHAN, 2000.

NOVAIS, Fernando A. Aproximações: estudos de história e historiografia. São Paulo: Cosac Naify, 2005.

OLIVEIRA, Francisco Baptista de. Noções elementares de urbanismo. Juiz de Fora: S.A. Lith e Mech União Industrial, 1937.

. Notas urbanísticas. Rio de Janeiro, s/d.

OLIVEIRA, Myriam A. R. Prefácio. In BURY, John. Arquitetura e Arte no Brasil colonial. Organizador Myriam A. R. de Oliveira. Brasília: IPHAN/Monumenta, 2006, pp.09-11.

OMEGNA, Nelson. A cidade colonial. 2 ed. Brasília: Ebrasa, INL, 1971.

OSBORN, F. J. Preface (1945). In HOWARD, E. Garden cities of To-morrow. 3 ed. London: Faber \& Faber, 1949. 
OUTTES, Joel. Disciplinando la sociedad a través de la ciudad: El origen del urbanismo em Argentina y Brasil (1894-1945). EURE (Santiago). [online]. mayo 2002, vol.28, no.83, pp.07-29. [disponível em http://www.scielo.cl/scielo.php?script=sci_arttext\&pid=S0250$71612002008300002 \& \operatorname{lng}=$ es\&nrm $=$ iso]

O Recife: gênese do urbanismo (1927-1943). Recife: FUNDAJ, Massangana, 1997.

PADILHA, Nino. (org.) Cidade e Urbanismo: história, teorias e práticas. Salvador: Mestrado em Arquitetura e Urbanismo, FAUUFBA, 1998.

PALHARES-BURKE, Maria L. G. Gilberto Freyre: um vitoriano nos trópicos. São Paulo: Ed Unesp, 2005.

PAPAYANIS, Nicholas. Planning Paris before Haussmann. Baltimore: The Johns Hopkins University Press, 2004.

PEARD, Julyan. G. Tropical disorders and the forging of a Brazilian Medical identity, 18601890. The Hispanic American Historical Review, vol.77, n.1, p.1-44, feb. 1997.

PECHMAN, Robert M. (org.). Olhares sobre a cidade. Rio de Janeiro: UFRJ, 1994.

Cidades estreitamente vigiadas: o detetive e o urbanista. Rio de Janeiro: Casa da Palavra, 2002.

PEIXOTO, Domingos R. dos Guimarães. Prolegômenos, ditados pela obediência, que servirão às observações, que for dando das moléstias cirúrgicas do país, em cada trimestre. In A saúde pública no Rio de Dom João. Introd. Moacyr Scliar. Rio de Janeiro: Editora Senac Rio, 2008, pp.85-118.

PELEGRINI, Sandra C. A. Representações: contribuições a um debate interdisciplinar [resenha ao livro organizado por Ciro F. Cardoso e Jurandir Malerba, Campinas, Papirus, 2000]. Revista Brasileira de História, São Paulo, v. 22, n. 43, 2000, p.245-250.

PELUSO JR, Victor. Tradição e plano urbano: cidades portuguesas e alemães em Santa Catarina. Boletim Geográfico, n.133, 1956.

PERRONE-MOISÉS, Leyla. Alegres trópicos: Gonneville, Thevet e Léry. Revista USP, n. 30 [dossiê Brasil dos viajantes], São Paulo, CCS, USP, jun./jul./ago. 1996, p.84-93.

PEREIRA, André L. T. Arquitetura, urbanismo e topografia em Ouro Preto no século XVIII. Dissertação, 2000 (Mestrado em História) - Campinas, Unicamp, IFCH, 2000.

PESAVENTO, Sandra J. (org.). Um historiador nas fronteiras: O Brasil de Sérgio Buarque de Holanda. Belo Horizonte: ed. UFMG, 2005.

"Paraísos cruzados: diálogos do encantamento e do desencantamento do mundo (Gilberto Freyre e Sérgio Buarque de Holanda)". s/d. 14 p. [disponível em: http://www.unicamp.br/siarq/sbh/paraisos_cruzados.pdf - acessado em 20 de junho de 2008]

. Muito além do espaço: por uma história cultural do urbano. Estudos Históricos, Rio de Janeiro, v. 8, n.16, 1995, p.279-290.

PICON, Antoine. Racionalidade técnica e utopia: a gênese da Haussmannização. In: Salgueiro, H. A. (org.) Cidades capitais do século XIX: racionalidade, cosmopolitismo e transferência de modelos, São Paulo: EDUSP, 2001, pp.65-101.

PIMENTA, Tânia S. Terapeutas populares e instituições médicas na primeira metade do século XIX. In In Chalhoub, S. et al. Artes e ofícios de curar no Brasil: capítulos de história social. Campinas: Ed. Unicamp, 2003, pp.308-330. 
PINHEIRO, Eloísa P. Europa, França e Bahia: difusão e adaptação de modelos urbanos (Paris, Rio e Salvador). Salvador: EDUFBA, 2002.

PINHEIRO, Eloisa P. e GOMES, Marco Aurélio A. de F. (orgs.) A cidade como história: os arquitetos e a historiografia da cidade e do urbanismo. Salvador: EDUFBA, 2004.

PINTO, Estevão. Pernambuco no século XIX. Recife: Imprensa industrial, 1922.

PITKIN, Hanna F. Representação: palavra, instituições e idéias. Lua Nova, São Paulo, n.67, 2006, p.15-47.

PIVA, Luiz G. Ladrilhadores e semeadores: a modernização brasileira no pensamento político de Oliveira Viana, Sérgio Buarque de Holanda, Azeredo Amaral e Nestor Duarte. (1920-1940). São Paulo: Ed. 34, 2000.

PORTO, Fernando. A cidade do Aracaju 1855/1865: ensaio de evolução urbana. 2 ed. Aracaju: Governo de Sergipe/FUNDESC, 1991. [ed. orig. 1945]

PRADO, Antonio A. No roteiro de Raízes. In Holanda, S. B. de. Raízes do Brasil. ed. rev. São Paulo: Companhia das Letras, 2006, pp.295-312. (edição comemorativa 70 anos, organizada por Ricardo B. de Araújo e Lilia M. Schwartz)

Raízes do Brasil e o modernismo. In Candido, A. (org.) Sérgio Buarque de Holanda e o Brasil. São Paulo: Editora Fundação Perseu Abramo, 1998, pp.71-80

PRADO, Paulo (1928). Retratos do Brasil. 9 ed. São Paulo: Companhia das Letras, 1997.

Paulística. São Paulo: Monteiro Lobato, 1925.

PRESTES, Maria E. B. A investigação da natureza no Brasil colônia. São Paulo: Annablume, FAPESP, 2000.

QUEIROZ, Marcus V. Dantas de. Quem te vê não te conhece mais: arquitetura e cidade de Campina Grande em transformação (1930-1950). Dissertação, 2008 (Mestrado em Arquitetura e urbanismo) - São Carlos, EESC-USP, 2008.

RAGO, Margareth. Do cabaré ao lar: a utopia da cidade disciplinar. Brasil 1890-1930. Rio de Janeiro: Paz e Terra, 1985.

REIS, Aarão L. de C. Laudos e pareceres tecnicos do Dr. Aarao Reis. Rio de Janeiro: Imprensa Nacional, 1925.

Commissão d'estudo das localidades indicadas para nova capital: relatorio apresentado a S. Ex. o Sr. Dr. Affonso Penna, Presidente do Estado. Rio de Janeiro: Imprensa Nacional, 1893.

REIS, Nestor Goulart. Imagens de vilas e cidades do Brasil colonial. São Paulo: FUPAM, 2000. (CD-ROM)

Contribuição ao estudo da evolução urbana do Brasil (1500/1720). 2 ed. rev. e ampl. São Paulo: Pini, 2000 [orig. 1968].

Quadro da Arquitetura no Brasil. 7 ed. São Paulo: Perspectiva, 1995.

Algumas experiências urbanísticas no início da República: 1890-1920.

Cadernos de Pesquisa do LAP. Ago. 1994.

REPS, John W. Bird's eye views: historic litographis of North American cities. New York: Princenton Architectural Press, 1998.

The making of Urban America: a history of city planning in the United States. Princenton: Princenton University Press, 1965.

REVAULT D'ALLONES, Myriam. Le dépéressiment de la politique: Généalogie d'un lieu commun. Paris : Flammarion, 1999. 
REZENDE, Vera. Evolução da produção urbanística na cidade do Rio de Janeiro, 19001950-1992. In LEME, Maria C. da S. Urbanismo no Brasil. São Paulo: FUPAM, Studio Nobel, 1999.

Planejamento urbano e ideologia: quatro planos para a cidade do Rio de Janeiro. Rio de Janeiro: Civilização Brasileira, 1982.

RIBEIRO, Luiz C. de Q. e PECHMAN, Robert M. (orgs.) Cidade, Povo e Nação: gênese do urbanismo moderno. Rio de Janeiro: Civilização Brasileira, 1996.

RICUPERO, Bernardo. Sete lições sobre as interpretações do Brasil. São Paulo: Alameda, 2007.

RIZEK, Cibele S. Os sentidos da cidade brasileira: figurações da ordem e de seus avessos. In VII Seminário de História da Cidade e do Urbanismo, Anais eletrônico [cd-rom], Salvador, PPGAU, UFBA, 2002. 11 p.

RODRIGUES, José Washt. Documentário arquitetônico relativo à antiga construção civil no Brasil. 4 ed. Belo Horizonte: Itatiaia; São Paulo: Edusp, 1979.

ROLNIK, Raquel. A cidade e a lei: legislação, política urbana e territórios na cidade de São Paulo. 2 ed. São Paulo: Studio Nobel, Fapesp, 1999.

ROMERO, José L. América Latina: as cidades e as idéias. trad. Bella Josef. Rio de Janeiro: Ed. UFRJ, 2004. [ed. orig. 1976]

ROSEN, George. Da polícia médica à medicina social: ensaios sobre a história da assistência médica. Rio de Janeiro: Edições Graal, 1980.

ROUANET, Sérgio Paulo. As razões do Iluminismo. São Paulo: Companhia das Letras, 1987.

RUSSEL-WOOD, A. J. R. United States scholarly contributions to the historiography of colonial Brazil. The Hispanic American Historical Review, vol.65, n.04, nov. 1985, p.683-723.

SAID, Edward W. Orientalismo: o Oriente como invenção do Ocidente. São Paulo: Companhia das Letras, 1990 [ed. orig. 1978].

SAINT-HILAIRE, Auguste de. Viagem pelas províncias do Rio de Janeiro e Minas Gerais. Trad. Vivaldi Moreira. São Paulo: Itatiaia, Edusp, 1975.

SALGUEIRO, Heliana A. (org.). Cidades capitais do século XIX: racionalidade, cosmopolitismo e transferência de modelos, São Paulo: EDUSP, 2001a.

Introdução: da temática, dos autores e de suas idéias. In: Salgueiro, H. A. (org.) Cidades capitais do século XIX: racionalidade, cosmopolitismo e transferência de modelos, São Paulo: EDUSP, 2001b, pp.19-40.

O pensamento francês na fundação de Belo Horizonte: das representações às práticas. In: Salgueiro, H. A. (org.) Cidades capitais do século XIX: racionalidade, cosmopolitismo e transferência de modelos, São Paulo: EDUSP, 2001c, pp.135-181.

Engenheiro Aarão Reis: o progresso como missão. Belo Horizonte: Sistema Estadual de Planejamento Fundação João Pinheiro, Centro de Estudos Históricos e Culturais, 1997.

A "volta" da história. In Barreto, Abílio. Belo Horizonte: memória histórica e descritiva - história antiga. Vol. I. 2 ed. atual. rev. e anot. Belo Horizonte: Fundação João Pinheiro, Centro de Estudos Históricos e Culturais, 1996, pp. 35-39.

SALIBA, Elias T. Perspectivas para uma historiografia cultural. Diálogos, Maringá, UEM, n.01, 1997, p.11-18. 
SANDES, Noé F. A invenção da Nação: entre a Monarquia e a República. Tese. São Paulo, 1997

SANTOS, Afonso C. M. dos. A invenção do Brasil: ensaios de história e cultura. Rio de Janeiro: Editora UFRJ, 2007.

SANTOS, Sidney M. G. dos. André Rebouças e seu tempo. Rio de Janeiro, s.n., 1985.

SANTOS, Paulo F. Formação de cidades no Brasil colonial. Rio de Janeiro: Ed. UFRJ, 2001 [orig. 1968]

Quatro séculos de arquitetura. s.l., Associação Brasileira de Escolas de Arquitetura, 1977 [orig. 1965].

Constantes da sensibilidade do Brasileiro: paralelo com as do português. Rio de Janeiro, s.n., 1975. (comunicação a ser apresentada ao $1^{\circ}$ Colóquio do Comitê Nacional de História da Arte).

Kosmos, 1951.

O barroco e o jesuítico na arquitetura do Brasil. Rio de janeiro: Livraria

SANTOS, W. R. de Almeira e VARGAS, Maria A. M. Apropriações na construção do urbano na cidade de Aracaju/SE. Scientia Plena, vol. 3, n. 5, 2007, pp.117-123 [disponível em: http://www.scientiaplena.org.br/sp_v3n5p117_123.pdf acessado em: 02 de junho de 2009]

SCHWARCZ, Lilia M. O espetáculo das raças: cientistas, instituições e questão racial no Brasil - 1870-1930. São Paulo: Companhia das Letras, 1993.

SCLIAR, Moacyr. Introdução. In A saúde pública no Rio de Dom João. Rio de Janeiro: Editora Senac Rio, 2008, pp.13-22.

SEGAWA, Hugo. Arquiteturas no Brasil 1900-1990. 2 ed. São Paulo: Edusp, 1999.

SEVCENKO, Nicolau. (1983) Literatura como Missão: tensões sociais e criação cultural na Primeira República. 4 ed. São Paulo:Brasiliense, 1999.

(Org.) História da vida privada no Brasil. Vol. 3. República: da Belle Époque a era do rádio. São Paulo: Companhia das Letras, 1998.

SILVA, Joana M. de C. e. Nacionalismo e Arquitetura em Ricardo Severo: Porto 1869 São Paulo 1940. Dissertação. 2005 (Mestrado em Arquitetura e Urbanismo) - São Carlos, EESC-USP, 2005.

SILVA, Manoel V. Reflexões sobre alguns dos meios propostos por mais conducentes para melhorar o clima da cidade do Rio de Janeiro [1808]. In A saúde pública no Rio de Dom João. Introd. Moacyr Scliar. Rio de Janeiro: Editora Senac Rio, 2008, pp.65-83.

SILVA, Wilton C. L. da. As terras inventadas: discurso e natureza em Jean de Léry, André João Antonil e Richard Francis Burton. São Paulo: Ed. Unesp, 2003.

SIMÕES JR., José Geraldo. Anhangabaú: história e urbanismo. São Paulo: Imprensa Oficial SP, SENAC, 2004.

O Setor de Obras Públicas e as Origens do Urbanismo na Cidade de São Paulo. Espaço \& Debates, São Paulo, NERU, n.34, 1991, pp.71-74.

SMITH, Robert C. Arquitetura civil do período colonial. In Arquitetura Civil I (textos escolhidos da Revista do IPHAN). São Paulo: FAUUSP, MEC/IPHAN, 1975, p. 95-190 [orig. 1969].

Urbanismo colonial no Brasil. Bem Estar, Urbanismo, Habitação. São Paulo, Ano 1 (1), p.14-22, fev.-mar. 1958. 
Colonial towns of Spanish and Portuguese. The Journal of the Society of Architectural Historians, vol. 14, n. 4, Town Planning Issue, dec. 1955, pp. 03-12.

Arquitetura colonial [as artes na Bahia - I Parte]. [Salvador]: Livraria Progresso Editora, 1955.74 p. + 20 lâminas il.

The Colonial Architecture of Minas Gerais in Brazil. The Art Bulletin, vol. 21, n. 2, jun. 1939, pp. 110-159.

SODRÉ, Nelson Werneck. O que se deve ler para conhecer o Brasil. 7 ed. Rio de Janeiro: Bertrand Brasil, 1997.

SOUSA, Alberto, NOGUEIRA, Helena de C. e VIDAL, Wylnna. Inovação no urbanismo brasileiro da Primeira República: o traçado de Saturnino de Brito para a expansão da capital paraibana. Arquitextos, São Paulo (on-line), n.70, texto especial 361, mar. 2006 [disponível em http://www.vitruvius.com.br/arquitextos/arq000/esp361.asp]

SOUZA, Laura de M. e. O Diabo e a Terra de Santa Cruz: feitiçaria e religiosidade popular no Brasil colonial. São Paulo: Companhia das Letras, 1986.

SOUZA, Valéria S. de. Gosto, sensibilidade e objetividade na representação da paisagem urbana nos álbuns ilustrados pelos viajantes europeus: Buenos Aires, Rio de Janeiro e México (1820-1852). 2 vols. Tese. 1995 (Doutorado em História) - São Paulo, FFLCH-USP, 1995.

SOUZA-LEÃO, J. de. Southey and Brazil. The Modern Language Review, vol. 38, n.03, jul. 1943, pp.181-191. [Stable URL: http://www.jstor.org/stable/3717458 Acessado em: 06/03/2009]

SPIX e MARTIUS. Viagem pelo Brasil. 2 vol. trad. L. F. Lahneyer. Rio de Janeiro, 1938.

STARKEY, Paul and STARKEY, Janet (ed.). Travellers in Egypt, London: Tauris Parke, 2001.

STEINKE, R. Z. Ruas curvas versus ruas retas: na história das cidades, três projetos do engenheiro Jorge de Macedo Viera. Dissertação (Mestrado em Arquitetura e Urbanismo) EESC/USP, São Carlos, 2002.

STOLS, Eddy. A iconografia do Brasil nos países baixos do século XVI ao século XX: uma tentativa de avaliação global. Revista USP, n. 30 [dossiê Brasil dos viajantes], São Paulo, CCS, USP, jun./jul./ago. 1996, p.22-31.

SÜSSEKIND. Flora. O Brasil não é longe daqui: o narrador, a viagem. São Paulo: Companhia das Letras, 1990.

TAFURI, Manfredo. Introducción: el proyecto histórico. In La esfera y el laberinto: vanguardias y arquitectura de Piranesi a los años setenta. Barcelona: Gustavo Gili, 1984 [ed. orig. 1980].

TEIXEIRA, Manuel C. e VALLA, Margarida. O Urbanismo Português. Séculos XIIIXVIII. Portugal-Brasil. Lisboa: Livros Horizonte, 1999.

TEIXEIRA, Manuel C. A influência dos modelos urbanos portugueses na origem da cidade brasileira. Seminário de História da Cidade e do Urbanismo, 4, Anais..., Rio de Janeiro: UFRJ/PROURB, vol. I, 1996.

THEODORO, Janice. América Barroca: temas e variações. São Paulo: Edups, Nova Fronteira, 1992.

TINEM, Nelci. O alvo do olhar estrangeiro: o Brasil na historiografia da arquitetura moderna. João Pessoa: Manufatura, 2002. 
TORRÃO FILHO, Amílcar. A arquitetura da alteridade: a cidade luso-brasileira na literatura de viagem (1783-1845). Tese. 2008 (Mestrado em História) - IFCH, Campinas, 2008.

Paradigma do caos ou cidade da conversão?: a cidade colonial na América portuguesa e o caso de São Paulo na administração do Morgado de Mateus (1765-1775). 2004. Dissertação (Mestrado em História) - IFCH-UNICAMP, Campinas, 2004.

Imagens de pitoresca confusão: a cidade colonial na América Portuguesa. Revista USP, São Paulo, n.57, p.50-67, mar-maio 2003.

TRAJANO FILHO, Francisco Sales. D.V.O.P.: arquitetura moderna, estado e modernização (Paraíba, década de 1930). Dissertação. 2003 (Mestrado em Arquitetura) - São Carlos, EESC-USP, 2003.

VAINFAS, Ronaldo (org.). Dicionário do Brasil Imperial (1822-1889). Rio de Janeiro: Objetiva, 2002.

Dicionário do Brasil Colonial (1500-1808). Rio de Janeiro: Objetiva, 2000.

Sérgio Buarque de Holanda: historiador das representações mentais. In Candido, A. (org.) Sérgio Buarque de Holanda e o Brasil. São Paulo: Editora Fundação Perseu Abramo, 1998, pp.49-57.

História das mentalidades e história cultural. In Cardoso, Ciro F. e Vainfas, Ronaldo (orgs.). Domínios da História: ensaios de Teoria e Metodologia. Rio de Janeiro: Campus, 1997, p.125-162.

VAINFAS, Ronaldo e NEVES, Lúcia B. P. das. (orgs.). Dicionário do Brasil Joanino (1808-1821). Rio de Janeiro: Objetiva, 2008.

VASCONCELLOS, Sylvio de. Formação urbana do Arraial do Tejuco. In Arquitetura Civil II (textos escolhidos da Revista do IPHAN). São Paulo: FAUUSP, MEC/IPHAN, 1975, p. 101-114 [orig. 1959].

Vila Rica: formação e desenvolvimentos, residências. São Paulo: Perspectivas, 1977.

VAUTHIER, Louis L. Diário íntimo do engenheiro Vauthier, 1840-1846. prefácio e notas de Gilberto Freyre. Rio de Janeiro: Serviço Gráfico do Ministério de Educação e Saúde, 1940.

Casas de residência no Brasil. In Arquitetura Civil I (textos escolhidos da Revista do IPHAN). São Paulo: FAUUSP, MEC/IPHAN, 1975, p. $27-94$ [orig. 1943].

VAZ, Francisco A. L. O pensamento económico do Bispo de Elvas, D. José Azeredo Coutinho. Revista Cultural de Marvão, 1998, pp.309-324.

VENTURA, Roberto. Estilo tropical: história cultural e polêmicas literárias no Brasil, 18701914. São Paulo: Companhia das Letras, 1991.

VIDAL, Emeric E. Buenos Aires y Montevideo. Buenos Aires: Emecé, 1999. [ed. orig. 1820]

VIDAL, Laurent. Mazagão, a cidade que atravessou o Atlântico: do Marrocos à Amazônia (1769-1783). trad. Marcos Macionilo. São Paulo: Martins, 2008.

VIERNO, Lívia. Semeadas e ladrilhadas: vilas e cidades no Brasil colônia. Tese. 2003 (Doutorado em Arquitetura e Urbanismo) - São Paulo, FAUUSP, 2003.

VILLAÇA, Flávio. Uma contribuição para a história do planejamento urbano no Brasil, In DEÁK, Csaba e SCHIFFER, Sueli R. (orgs.) O processo de urbanização no Brasil. São Paulo: Edusp, 1999, pp.169-243. 
Espaço intra-urbano no Brasil. São Paulo: Nobel, 1998.

WEGNER, Robert. A conquista do Oeste: a fronteira na obra de Sérgio Buarque de Holanda. Belo Horizonte: Ed. UFMG, 2000.

WOHL, Hellmuth. Robert Chester Smith e a História da Arte nos Estados Unidos. In Fundação Calouste Gulbekian. Robert C. Smith (1912-1975): a investigação na História da Arte. Lisboa: Fundação Calouste Gulbekian, [2000], p.17-29.

WRIGHT, Gwendolyn. The politics of design in French colonial urbanism. Chicago, The University of Chicago Press, 1991.

RUSSEL-WOOD, A. J. R. United States scholarly contributions to the historiography of colonial Brazil. The Hispanic American Historical Review, vol.65, n.04, nov. 1985, pP.683-723.

XAVIER, Alberto (org.). Depoimento de uma geração: arquitetura moderna brasileira. ed. rev. ampl. São Paulo: Cosac \& Naify, 2003.

ZANCHETI, Silvio. Formação e Consolidação da Repartição de Obras Públicas de Pernambuco (1836-1844). Espaço \& Debates, São Paulo, NERU, n. 34, 1991, pp.75-83.

\section{Fontes primárias}

ALMEIDA, Cândido Mendes de. Atlas do Império do Brazil: comprehendendo as respectivas divisões administrativas, ecclesiasticas, eleitoraes e judiciárias. Dedicado a sua Magestade o Imperador Senhor D. Pedro II, destinado a Instrucção Publica no Império com especialidade a dos alumnos do Imperial Collegio de Pedro II. Rio de Janeiro: Typographia do Instituto Philomatico, 1868.

AZEREDO COUTINHO, José Joaquim da Cunha de [Bispo d'Elvas]. Ensaio economico sobre o commercio de Portugal e suas colonias. 2 ed. corr. aum. Lisboa: Typografia da Academia Real das Sciencias, 1816 [1 ed. 1794].

BEAUREPAIRE-ROHAN, Henrique de. Relatório apresentado à Ilma. Câmara Municipal do Rio de Janeiro, 1843. In ANDREATTA, Verena. Cidades quadradas, paraísos circulares: os planos urbanísticos para o Rio de Janeiro no século XIX. Rio de Janeiro: Mauad X, 2006, Anexos, pp.03-09.

BURFORD, Robert. Description of a view of the city of St. Sebastian and the Bay of Rio de Janeiro. London: J. and C. Adlard, Bartholomew Close, 1827.

BLUTEAU, Raphael. Vocabulario Portuguez \& Latino, áulico, anatômico, architectonico... 8 vols. Coimbra, 1712-1728 [edição on-line do Instituto de Estudos Brasileiros - USP, disponível em: http://www.ieb.usp.br/online/index.asp]

CANDIDO, Francisco de Paula. Relatório acerca da Saúde Publica. Rio de Janeiro: Typographia Nacional, 1856.

COMISSÃO DE SANEAMENTO DE NATAL. Relatório de Abril de 1924 (assinado pelo eng. Henrique de Novaes), Natal, s.n., 1924. [datilografado]

HORNER, Gustavus R. B. Medical topography of Brazil and Uruguay with incidental remarks. Philadelphia: Lindsay \& Blakiston, 1843.

KIDDER, David P. and FLETCHER, J. C. Brazil and the Brazilians: portrayed in historical and descriptive sketches. Philadelphia: Childs \& Peterson, 1857.

KOSTER, Henry. Travels in Brazil. London: Longman, Hurst, Rees, Orme, and Brown, 1816. 
MACCARTHY, Jacques. Choix de voyages dans les quatre parties du monde. Paris: Vve Dabo Mason, 1821.

PEIXOTO, Domingos Ribeiro dos Guimaraens. Aos sereníssimos Príncipes Reais do Reino Unido de Portugal e do Brasil e Algarves, os senhores D. Pedro de Alcântara e D. Carolina Josefa Leopoldina oferece, sem sinal de gratidão, amor, respeito e reconhecimento estes Prolegômenos, ditados pela obediência, que servirão às observações, que for dando das moléstias cirúrgicas do País, em cada trimestre [1820]. In A saúde pública no Rio de Dom João. Rio de Janeiro: Editora Sena Rio, 2008, pp.84-118.

REGO, José Pereira [Barão do Lavradio]. Memória histórica das epidemias de febre amarela e cólera-morbo que têm reinado no Brasil. Rio de Janeiro: Typographia Nacional, 1873.

Esboço histórico das epidemias que têm grassado na cidade do Rio de Janeiro desde 1830 a 1870. Rio de Janeiro: Typographia Nacional, 1872.

Historia e descripção da febre amarella epidemica que grassou no Rio de Janeiro em 1850 por... Rio de Janeiro: Paula Brito, 1851.

SILVA, Manoel Vieira da. Reflexões sobre alguns dos meios propostos por mais conducentes para melhorar o clima da cidade do Rio de Janeiro [1808]. In A saúde pública no Rio de Dom João. Rio de Janeiro: Editora Sena Rio, 2008, pp.64-83.

SOUTHEY, Robert. Koster's travels in Brazil. The Quartely Review. London, printed for John Murray, vol. XVI, n. 32, oct.1816-jan.1817, p.344-387.

WATSON, Robert Grant. Spanish and Portuguese South América during the colonial period. 2 vols. London: Trübner \& Co. Ludgate Hill, 1884.

\section{Documentação seriada}

ANAIS do MUSEU HISTÓRICO NACIONAL. Rio de Janeiro. vols. I-X, 1940-1949.

ARCHIVO ILLUSTRADO: encyclopedia noticiosa, scientifica e literária. São Paulo. 18991906.

BRASIL ILLUSTRADO, (O): publicação litteraria. Rio de Janeiro, n. 1-18, 1855-1856.

EU SEI TUDO. Magazine mensal ilustrado. Rio de Janeiro. 1919-1920.

ILLUSTRAÇÃO BRASILEIRA. Rio de Janeiro. ns. 01-40, 1876-1878.

REVISTA do INSTITUTO HISTÓRICO E GEOGRAPHICO BRASILEIRO.

REVISTA do INSTITUTO HISTÓRICO E GEOGRAPHICO DE SÃO PAULO. vols. IV-XI, 1898-1907.

REVISTA [Boletim] da SOCIEDADE DE GEOGRAPHIA DO RIO DE JANEIRO. Rio de Janeiro, tomos I-V, 1885-1889.

REVUE DU BRÉSIL. 1876-1877.

VELHO BRASIL, (O). Rio de Janeiro, 1853-1854. 